Nevada

DOE/NV--478-REV. 1

Environmental

Restoration

Project

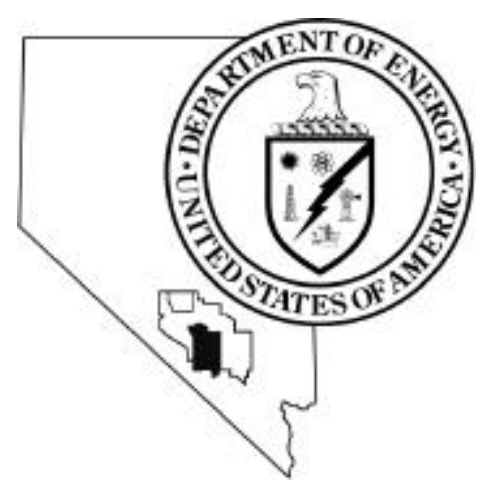

Corrective Action Investigation Plan

for Corrective Action Unit 98 :

Frenchman Flat, $\mathrm{N}$ evada Test $\mathrm{Site}$,

Nevada

Controlled Copy N 0.: --

Revision N 0.: 1

J uly 1999

Approved for public release; further dissemination unlimited.

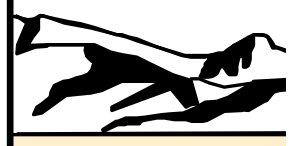

Environm ental Restoration

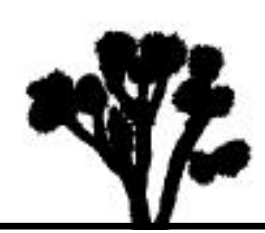

Division 
Available to the public from -

U.S. Department of Commerce

National Technical Information Service

5285 Port Royal Road

Springfield, VA 22161

(703) 487-4650

Available electronically at http://www.doe.gov/bridge. Available to U.S. Department of Energy and its contractors in paper from -

U.S. Department of Energy

Office of Scientific and Technical Information

P.O. Box 62

Oak Ridge, TN 37831-0062

(423) 576-8401 


\title{
CORRECTIVE ACTION INVESTIGATION PLAN FOR CORRECTIVE ACTION UNIT 98: FRENCHMAN FLAT, NEVADA TEST SITE, NEVADA
}

\author{
DOE Nevada Operations Office \\ Las Vegas, Nevada
}

Controlled Copy No.:

Revision No.: 1

July 1999

Approved for public release; further dissemination unlimited. 


\section{CORRECTIVE ACTION INVESTIGATION PLAN FOR CORRECTIVE ACTION UNIT 98: FRENCHMAN FLAT, NEVADA TEST SITE, NEVADA}

\begin{tabular}{lr} 
Approved by: & Signature Approved \\
\cline { 2 - 2 } & $\begin{array}{l}\text { Robert M. Bangerter, Project Manager } \\
\text { Underground Test Area Project }\end{array}$
\end{tabular}

Approved by:_ Signature Approved Date: 7/20/99

Runore C. Wycoff, Division Director

Environmental Restoration Division 


\section{Table of Contents}

List of Figures. . . . . . . . . . . . . . . . .

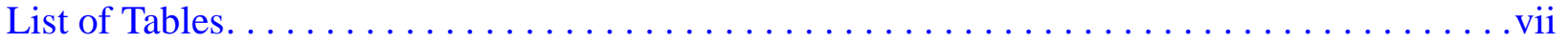

List of Acronyms and Abbreviations $\ldots \ldots \ldots \ldots \ldots \ldots \ldots \ldots \ldots \ldots \ldots \ldots \ldots \ldots$

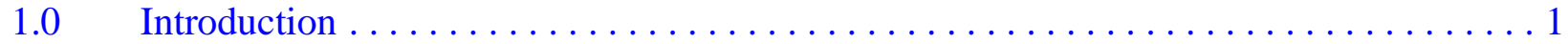

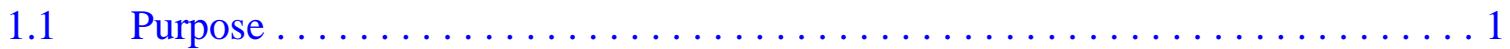

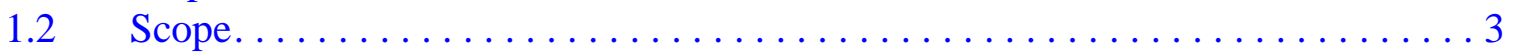

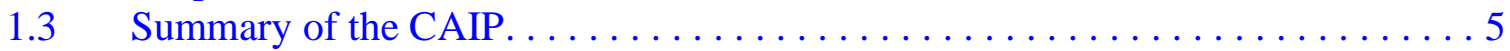

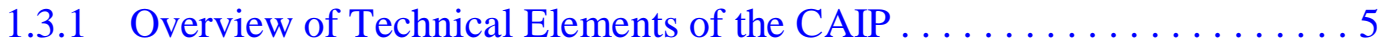

1.3.1.1 Assessment of CAU-Related Data ............... . . 5

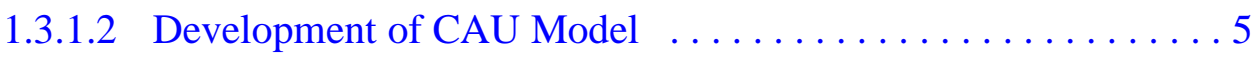

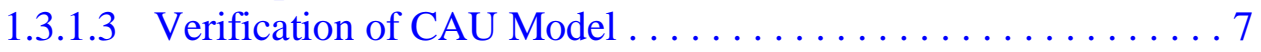

1.3.1.4 Prediction of Contaminant Boundary $\ldots \ldots \ldots \ldots \ldots \ldots$

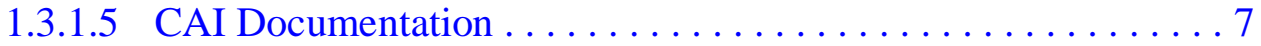

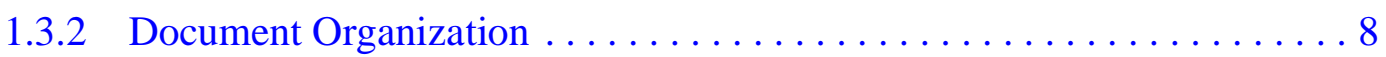

$2.0 \quad$ Legal/Regulatory Requirements . . . . . . . . . . . . . . . . . . 10

$2.1 \quad$ Federal Facility Agreement and Consent Order . . . . . . . . . . . . . . . 10

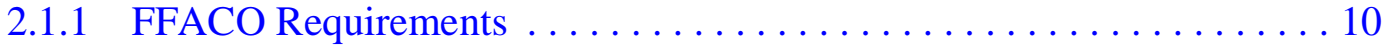

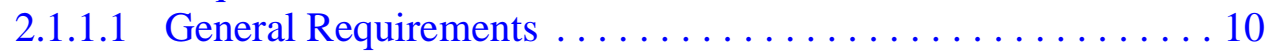

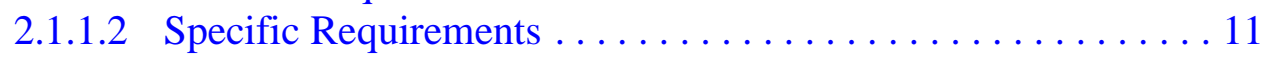

2.1.2 Corrective Action Strategy . . . . . . . . . . . . . . . 13

2.1.2.1 Description of Corrective Action Strategy . . . . . . . . . . . 13

2.1.2.1.1 General Definition of Contaminant Boundary . . . . 14

2.1.2.1.2 Process Description ............... 14

2.1.2.2 Implementation of the Corrective Action Strategy . . . . . . . 18

2.1.2.2.1 Specific Definition of the Contaminant

Boundary ...................... 18

2.1.2.2.2 Corrective Action Investigation . . . . . . . . 18

2.1.2.2.3 Corrective Action Implementation and

CAU Closure ..................... 21

3.0 Description of the Corrective Action Unit $\ldots \ldots \ldots \ldots \ldots \ldots \ldots \ldots \ldots \ldots \ldots \ldots \ldots$

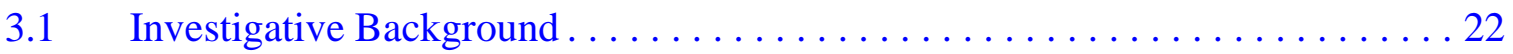

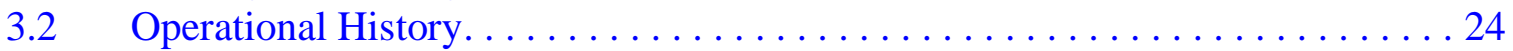

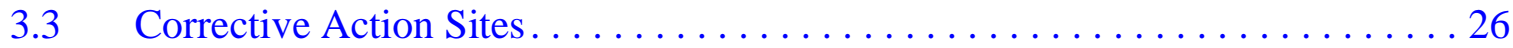

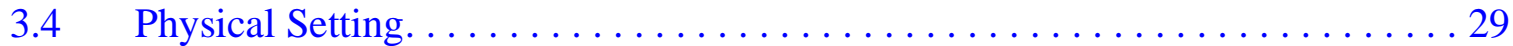

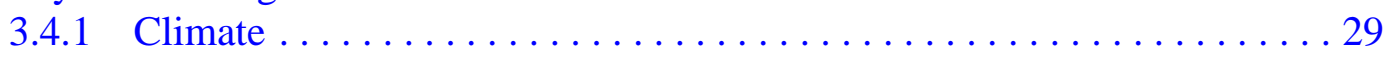




\section{Table of Contents (Continued)}

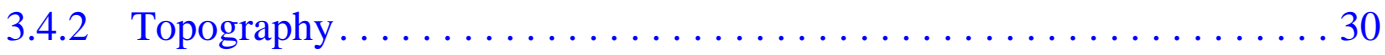

3.4 .3 Surface Water ................................. 30

3.4 .4 Geology .................................. 30

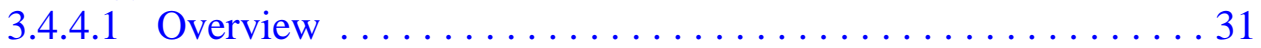

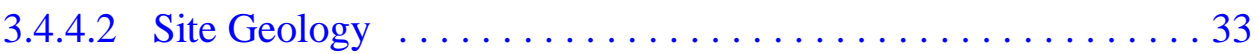

3.4.5 Hydrogeology .................................. 35

3.4.5.1 Regional Hydrogeology . . . . . . . . . . . . . . . . . . . . . 35

3.4.5.1.1 Hydrostratigraphy ..................... 35

3.4.5.1.2 Groundwater .................... 43

3.4.5.2 Hydrogeology of the Investigation Area .............. 47

3.4.5.2.1 Hydrostratigraphy .................... 47

3.4.5.2.1.1 Pre-Tertiary Age HSUs . . .......... 47

3.4.5.2.1.2 Tertiary-Age HSUs in the

Frenchman Flat Area ............48

3.4.5.2.1.3 Quaternary-Age HSUs in the

Frenchman Flat Area .............50

3.4.5.2.2 Groundwater .................... 50

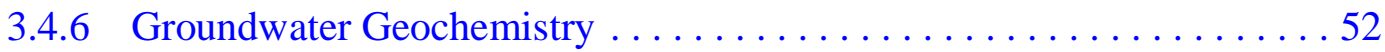

3.4.6.1 General Chemistry ....................... 54

3.4.6.2 Stable and Environmental Isotopes . . . . . . . . . . . . 57

3.4.7 Groundwater Radiological Chemistry . . ................. 64

3.4.7.1 CAMBRIC Radionuclide Migration Project .............6 65

3.4.7.2 Non-CAMBRIC Radionuclide Data . . . . . . . . . . . . . 70

3.4.8 Contaminant Transport Parameters . . . . . . . . . . . . . . . . . 70

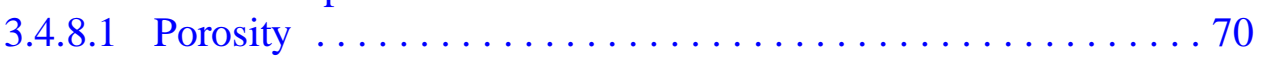

3.4.8.2 Dispersion ............................... 76

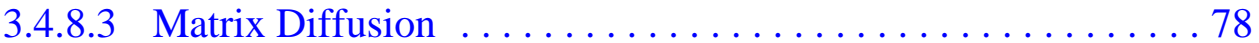

3.4.8.4 Distribution Coefficients ....................... . 80

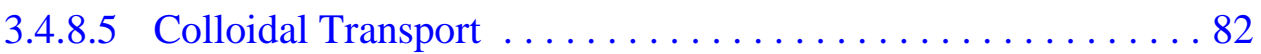

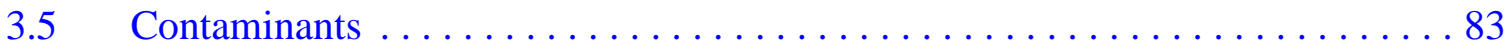

3.5.1 Radioactive and Hazardous Substances Present. . . . . . . . . . . . . . . . 84

3.5.2 Potential Contaminants for the CAI . . . . . . . . . . . . . . 84

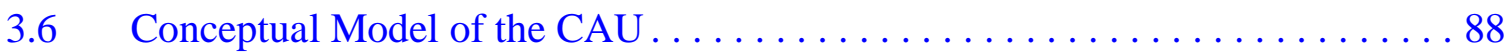

3.6.1 Overview of Conceptual Model . . . . . . . . . . . . . . . . . . . . . . 89 89

3.6.2 Release and Discharge Mechanisms......................... 94

3.6.2.1 Release Mechanisms .......................... 94

3.6.2.2 Discharge Mechanisms ...................... 100

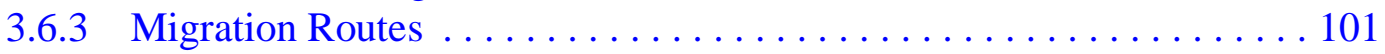

3.6.3.1 Groundwater Flow Paths ...................... 101

3.6.3.2 Travel Times and Contaminant Concentrations ......... 103

3.6.4 Contaminated Media. . . . . . . . . . . . . . . . . . . . . . . . . . 104 


\section{Table of Contents (Continued)}

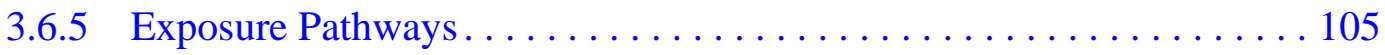

3.6.6 Uncertainties. . . . . . . . . . . . . . . . . . . . . . . . 106

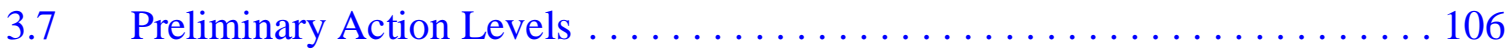

$4.0 \quad$ Summary of Data Quality Objectives. . . . . . . . . . . . . . . . . 108

$4.1 \quad$ Data Quality Objectives Approach . . . . . . . . . . . . . . . . . 108

4.2 Data Quality Objectives Results . . . . . . . . . . . . . . . . . . 111

4.2.1 Results of DQO Seven-Step Method . . . . . . . . . . . . . . . . . 111

4.3 Relationship Between DQO Results and Migration Routes . . . . . . . . . . 116

$5.0 \quad$ Corrective Action Investigation $\ldots \ldots \ldots \ldots \ldots \ldots \ldots \ldots \ldots \ldots \ldots \ldots \ldots$

5.1 Groundwater Flow and Contaminant Transport Model . . . . . . . . . 118

5.1 .1 Modeling Process Overview. . . . . . . . . . . . . . . . . . . 118

5.1 .2 Model Objectives . . . . . . . . . . . . . . . . . . . . . 121

5.1 .3 Data Assessment. . . . . . . . . . . . . . . . . . . . . 123

5.1.3.1 Data Assessment for Groundwater Flow Model . . . . . . . . . 125

5.1.3.2 Data Assessment for Contaminant Transport Model . . . . . 129

5.1 .4 Code Selection . . . . . . . . . . . . . . . . . . . . . . . . . . 134

5.1.4.1 Code Attributes . . . . . . . . . . . . . . . . . . . . . 134

5.1.4.2 Code Identification and Preliminary Selection . . . . . . . . . 139

5.1.4.3 Code Testing and Final Code Selection Process . . . . . . . . . . 140

5.1.4.4 Comparison of the Candidate Codes . . . . . . . . . . . . . . . . 144

5.1.4.5 Final Code Selection ..................... 151

5.1 .5 Model Construction . . . . . . . . . . . . . . . . . . 152

5.1.5.1 Groundwater Flow Model . . . . . . . . . . . . . . . . . 152

5.1.5.1.1 Model Setup . . . . . . . . . . . . . . . . . . 152

5.1.5.1.2 Groundwater Flow Model Calibration . . . . . . . 155

5.1.5.2 Contaminant Transport Model . . . . . . . . . . . . . 157

5.1.5.2.1 Model Setup . . . . . . . . . . . . . . . 157

5.1.5.2.2 Transport Model Calibration ............ 157

5.1 .6 Sensitivity Analyses . . . . . . . . . . . . . . . . . . . 158

5.1 .7 Uncertainty Analyses . . . . . . . . . . . . . . . . . . 158

5.1 .8 Model Review. . . . . . . . . . . . . . . . . . . . . . . . . . 162

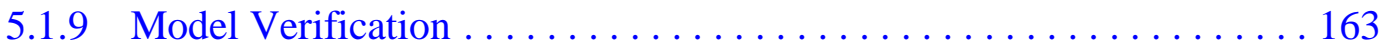

5.1 .10 Model Predictions . . . . . . . . . . . . . . . . . . . . . . . 164

5.1 .11 Model Documentation . . . . . . . . . . . . . . . . . 165

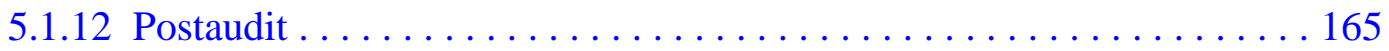

5.2 Other Models Supporting the Frenchman Flat CAU Model. . . . . . . . . . . . 166

5.2 .1 Regional Groundwater Flow Model . . . . . . . . . . . . . . . . . . 166

5.2 .2 Random Field Generator. . . . . . . . . . . . . . . . . . . . 167

5.2 .3 Near-Field Model . . . . . . . . . . . . . . . . . . . . . 168 


\section{Table of Contents (Continued)}

$6.0 \quad$ Field Investigation/No Field Investigation . . . . . . . . . . . . . . . . . 169

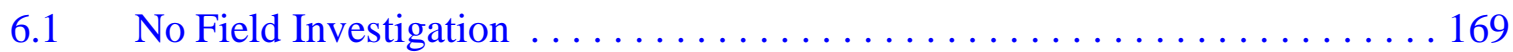

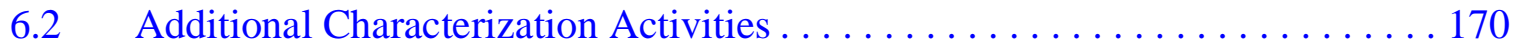

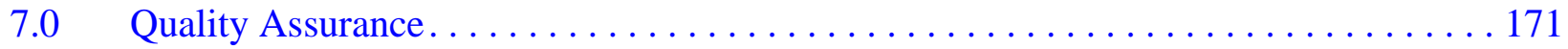

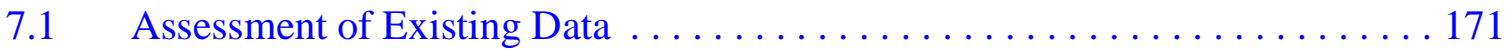

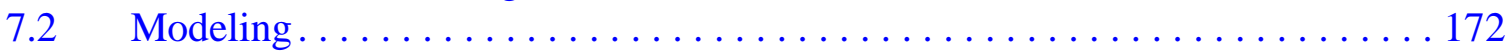

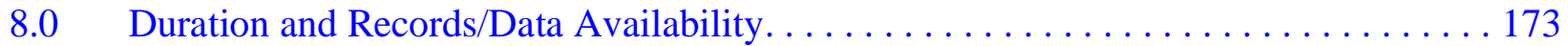

8.1 Document/Records Availability . . . . . . . . . . . . . . 173

$9.0 \quad$ References..................................... 174

\section{Appendix A - Data Quality Objectives Worksheet}

A.1.0 Data Quality Objectives Worksheet for Frenchman Flat Corrective Action Unit . . . . A-1

A.2.0 References................................... A-8 


\section{List of Figures}

Number

Title

Page

1-1 Location of the Frenchman Flat Corrective Action Unit. . . . . . . . . . . . . 2

1-2 Location of Frenchman Flat Investigation and Potential Model Areas. . . . . . . . 4

1-3 Overview of the Technical Elements of the Frenchman Flat CAIP . . . . . . 6

2-1 Example of Contaminant Boundary Confidence Levels . . . . . . . . . . . . . 15

2-2 Decision Diagram for the Underground Test Area .............. 16

3-1 Location of Underground Nuclear Tests in Frenchman Flat. . . . . . . . . . . 27

3-2 Frenchman Flat Corrective Action Unit Cross-Section Location Map. . . . . . . . 36

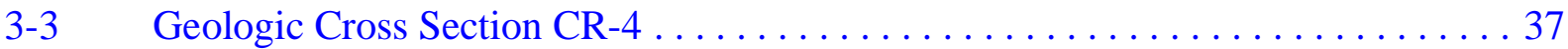

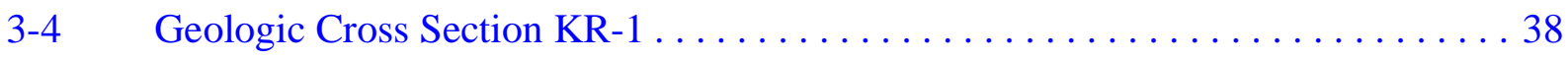

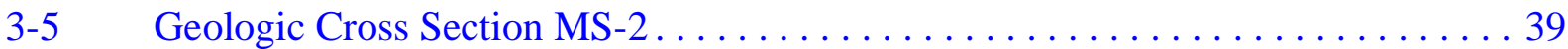

3-6 Features of the Nevada Test Site Regional Groundwater Flow System . . . . . . . 44

3-7 Location of Wells and Average Water Levels within Frenchman Flat

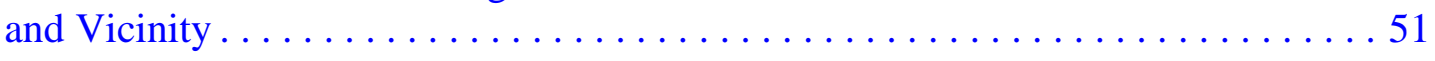

3-8 Simulated Regional Hydraulic Heads Contours in Frenchman Flat Area

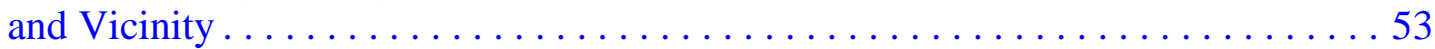

3-9 Piper Diagram Showing Major Ion Concentration Percentages for Frenchman Flat Groundwater Using Average Concentration Data . . . . . . . . . 55

3-10 Stable Isotope Composition of Groundwater $\ldots \ldots \ldots \ldots \ldots \ldots \ldots \ldots \ldots \ldots$

3-11 Radionuclide Concentrations in Groundwater at Well RNM-1 . . . . . . . 67

3-12 Radionuclide Concentrations in Groundwater at Well RNM-2S . . . . . . . . 69

3-13 Plan View of Frenchman Flat Conceptual Model

(Groundwater pathlines are superposed on plan view of hydrostratigraphic model at water table.) $\ldots \ldots \ldots \ldots \ldots \ldots \ldots \ldots \ldots \ldots \ldots \ldots \ldots$

3-14 Downgradient Distance of $4 \mathrm{mrem} / \mathrm{yr}$ Dose from Location of DILUTED WATERS Nuclear Test in Frenchman Flat, at 95\% Confidence

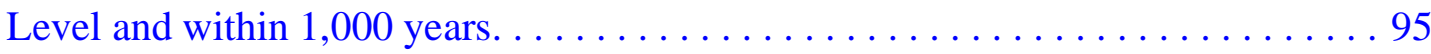




\section{List of Figures (Continued)}

Number

3-15 Downgradient Distance of $4 \mathrm{mrem} / \mathrm{yr}$ Dose from Location of MINUTE STEAK Nuclear Test in Frenchman Flat, at 95\% Confidence

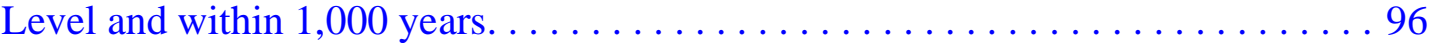

3-16 Introduction or Distribution of Radionuclides from Underground Tests to Hydrologic Source Term and Groundwater Flow System . . . . . . . . . . . . . 97

3-17 Simulated Groundwater Pathlines from Frenchman Flat Nuclear Test Locations for a 200-Year Period . . . . . . . . . . . . . . . . . . . . . 102

4-1 Relationship Between DQO Process and Supporting Tasks . . . . . . . . . . 110

5-1 Modeling Process for the Frenchman Flat CAU . . . . . . . . . . . . . . . 119

5-2 Approximate Schedule for Frenchman Flat Corrective Action Investigation Activities . . . . . . . . . . . . . . . . . . 122

5-3 Data Utilization During the CAU Modeling Process . . . . . . . . . . . . . 124

5-4 Data Types and Utilization in the Groundwater Flow Model . . . . . . . . . . 126

5-5 Data Types and Utilization in the Contaminant Transport Model . . . . . . . 130

5-6 Area of Frenchman Flat Test Problem . . . . . . . . . . . . . . . . . . 143 


\section{List of Tables}

Number

3-1 Corrective Action Sites in the Frenchman Flat Corrective Action Unit . . . . . . . 28

3-2 Pre-Tertiary Stratigraphy and Hydrostratigraphy of the Nevada Test

Site Region . . . . . . . . . . . . . . . . . . . . . . . . . . . . . . 32

3-3 Quaternary and Tertiary Stratigraphy and Hydrostratigraphy

of the Nevada Test Site Region. . . . . . . . . . . . . . . . . . . . . . 34

3-4 Hydrostratigraphic Units/Geologic Model Layers of the Nevada

Test Site Region . . . . . . . . . . . . . . . . . . . . . . 41

3-5 Ranges of Hydraulic Conductivity for the Major Aquifers of the Nevada Test Site Region. . . . . . . . . . . . . . . . . 42

3-6 Hydraulic Conductivity Decay Coefficients with Depth. . . . . . . . . . . 43

3-7 Estimate Steady-State Groundwater Budget for the

Nevada Test Site Regional Groundwater Flow System . . . . . . . . . . . . . . . . 46

3-8 Hydraulic Conductivity Summary Statistics for the Volcanic

Hydrostratigraphic Units of Pahute Mesa

(Variable is $\log [\mathrm{K}]$ with $\mathrm{K}$ in meters per day) . . . . . . . . . . . . . . 47

3-9 General Chemistry Summary Statistics for Wells Located in

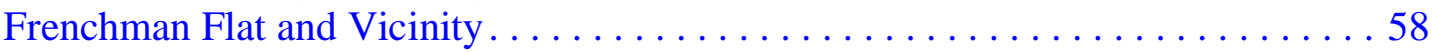

3-10 Stable Isotope and Carbon-14 Data. . . . . . . . . . . . . . . . . 61

3-11 Radionuclide Concentrations in Groundwater at Well RNM-1 . . . . . . . 66

3-12 Radionuclide Concentrations in Groundwater ................. 71

3-13 Statistical Summary of Porosity Data $\ldots \ldots \ldots \ldots \ldots \ldots \ldots \ldots \ldots \ldots \ldots$

3-14 Effective Porosity Estimates from Tracer Tests Conducted at or near the Nevada Test Site . . . . . . . . . . . . . . . . . . . . . . . . . . . . . . . 75

3-15 Fracture Porosity Obtained from the Study of Volcanic Core . . . . . . . . . 75

3-16 Longitudinal Dispersivity Information Summary from Tracer Tests

Conducted at or near the Nevada Test Site . . . . . . . . . . . . . . 77

3-17 Tritium and Technetium Diffusion Coefficients

for the Welded Tuff Aquifer, Yucca Mountain. . . . . . . . . . . . . . . . . . . . 79

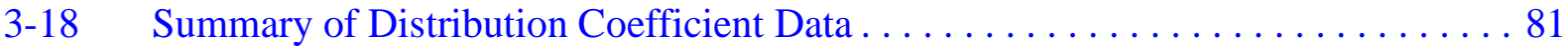




\section{List of Tables (Continued)}

Number

3-19 Materials Involved in Underground Nuclear Testing . . . . . . . . . 85

3-20 Comprehensive List of Radionuclides Related to Underground Testing . . . . . . 86

3-21 Preliminary List of Potential Contaminants for UGTA $\ldots \ldots \ldots \ldots \ldots$

3-22 Maximum Observed Concentrations of Potential Radioactive Contaminants in Frenchman Flat Nuclear Test Cavity Groundwater . . . . . . . . . . . . . . . 89

3-23 Preliminary Action Levels for Potential Contaminants. . . . . . . . . . . . . . 107

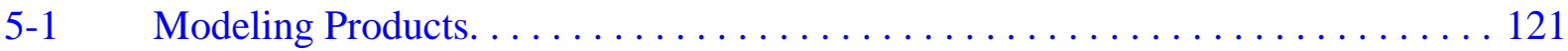

5-2 Desired Hydrologic Code Attributes. . . . . . . . . . . . . . . . 135

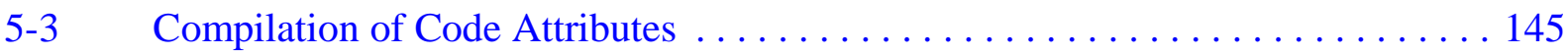

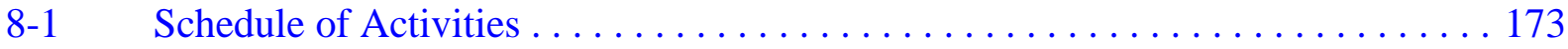




\section{List of Acronyms and Abbreviations}

\begin{tabular}{|c|c|}
\hline$\delta^{13} \mathrm{C}$ & Delta Carbon-13 \\
\hline$\delta \mathrm{D}$ & Delta Deuterium \\
\hline$\delta^{18} \mathrm{O}$ & Delta Oxygen-18 \\
\hline${ }^{106} \mathrm{Ru}$ & Ruthenium-106 \\
\hline${ }^{125} \mathrm{Sb}$ & Antimony-125 \\
\hline${ }^{129} \mathrm{I}$ & Iodine-129 \\
\hline${ }^{36} \mathrm{Cl}$ & Chlorine-36 \\
\hline${ }^{137} \mathrm{Cs}$ & Cesium-137 \\
\hline${ }^{13} \mathrm{C}$ & Carbon-13 \\
\hline${ }^{14} \mathrm{C}$ & Carbon-14 \\
\hline${ }^{239 / 240} \mathrm{Pu}$ & Plutonium-239/240 \\
\hline${ }^{85} \mathrm{Kr}$ & Krypton-85 \\
\hline${ }^{90} \mathrm{Sr}$ & Strontium-90 \\
\hline${ }^{238} \mathrm{U}$ & Uranium-238 \\
\hline $3-\mathrm{D}$ & Three dimensional \\
\hline amsl & Above mean sea level \\
\hline ASTM & American Society for Testing and Materials \\
\hline bgs & Below ground surface \\
\hline BLM & U.S. Bureau of Land Management \\
\hline $\mathrm{BN}$ & Bechtel Nevada \\
\hline CADD & Corrective Action Decision Document \\
\hline CAI & Corrective Action Investigation(s) \\
\hline CAIP & Corrective Action Investigation Plan \\
\hline CAP & Corrective Action Plan \\
\hline CAS & Corrective Action Site(s) \\
\hline CAU & Corrective Action Unit(s) \\
\hline
\end{tabular}




\section{List of Acronyms and Abbreviations (Continued)}

CERCLA Comprehensive Environmental, Response, Compensation, and Liability Act

$\mathrm{cm} \quad$ Centimeter(s)

$\mathrm{cm}^{2} \quad$ Square centimeter(s)

$\mathrm{cm}^{2} / \mathrm{s} \quad$ Square centimeter(s) per second

$\mathrm{CO}_{2} \quad$ Carbon dioxide

DoD U.S. Department of Defense

DOE/NV U.S. Department of Energy, Nevada Operations Office

DOE U.S. Department of Energy

DOT U.S. Department of Transportation

DQO Data Quality Objective(s)

DRI Desert Research Institute

EIS Environmental Impact Statement

EPA U.S. Environmental Protection Agency

ERP Environmental Restoration Project

ET Evapotranspiration

FFACO Federal Facility Agreement and Consent Order

FMP Fluid Management Plan

$\mathrm{ft} / \mathrm{d} \quad$ Foot (feet) per day

$\mathrm{ft} \quad$ Foot (feet)

$\mathrm{ft}^{2} / \mathrm{s} \quad$ Square foot (feet) per second

$\mathrm{HCO}_{3} \quad$ Carbonate

HRMP Hydrologic Resources Management Program

HSU Hydrostratigraphic unit(s)

in. $\operatorname{Inch}(\mathrm{es})$

IT IT Corporation

K Potassium 


\section{List of Acronyms and Abbreviations (Continued)}

\begin{tabular}{|c|c|}
\hline $\mathrm{K}_{\mathrm{d}}$ & Distribution coefficient \\
\hline $\mathrm{km}$ & Kilometer(s) \\
\hline $\mathrm{kt}$ & Kiloton \\
\hline LANL & Los Alamos National Laboratory \\
\hline LLNL & Lawrence Livermore National Laboratory \\
\hline $\mathrm{m}$ & Meter(s) \\
\hline MCL & Maximum Contaminant(s) Limit \\
\hline $\mathrm{m} / \mathrm{d}$ & Meter(s) per day \\
\hline $\mathrm{m}^{3} / \mathrm{d}$ & Cubic meter(s) per day \\
\hline $\mathrm{m}^{2} / \mathrm{d}$ & Square meter(s) per day \\
\hline $\mathrm{Mg}$ & Magnesium \\
\hline $\mathrm{mg} / \mathrm{L}$ & Milligram(s) per liter \\
\hline $\mathrm{mi}$ & Mile(s) \\
\hline mrem & Millirem(s) \\
\hline $\mathrm{mrem} / \mathrm{yr}$ & Millirem(s) per year \\
\hline MWL & Meteoric water line \\
\hline $\mathrm{Na}$ & Sodium \\
\hline NAFR & Nellis Air Force Range \\
\hline NDEP & Nevada Division of Environmental Protection \\
\hline NEPA & National Environmental Policy Act \\
\hline NHPA & National Historic Preservation Act \\
\hline NPDES & National Pollutant Discharge Elimination System \\
\hline NTS & Nevada Test Site \\
\hline PAL & Preliminary action level \\
\hline $\mathrm{PC}$ & Personal computer \\
\hline pdf & Probability density function(s) \\
\hline
\end{tabular}




\section{List of Acronyms and Abbreviations (Continued)}

QAPP Quality Assurance Project Plan

RCRA Resource Conservation and Recovery Act

RNM Radionuclide Migration

SDWA Safe Drinking Water Act

TDS Total Dissolved Solids

TNT Trinito toluene

TWG Technical Working Group

UGTA Underground Test Area

UIC Underground Injection Control

USAF U.S. Air Force

USGS U.S. Geological Survey

VOIA Value of Information Analysis

${ }^{\circ} \mathrm{C} \quad$ Degree(s) Celsius

${ }^{\circ} \mathrm{F} \quad$ Degree(s) Fahrenheit

$\%$ Per mil 


\subsection{Introduction}

This Corrective Action Investigation Plan (CAIP) has been developed for Frenchman Flat Corrective Action Unit (CAU) 98. The Frenchman Flat CAU is located along the eastern border of the Nevada Test Site (NTS) and includes portions of Areas 5 and 11 (Figure 1-1). The Frenchman Flat CAU constitutes one of several areas of the Nevada Test Site used for underground nuclear testing in the past. The nuclear tests resulted in groundwater contamination in the vicinity as well as downgradient of the underground test areas. The CAIP describes the Corrective Action Investigation (CAI) to be conducted at the Frenchman Flat CAU to evaluate the extent of contamination in groundwater due to the underground nuclear testing. The Frenchman Flat CAI will be conducted by the Underground Test Area (UGTA) Project which is a part of the U.S. Department of Energy, Nevada Operations Office (DOE/NV) Environmental Restoration Project. The CAIP is a requirement of the Federal Facility Agreement and Consent Order (FFACO) (1996) agreed to by the U.S. Department of Energy (DOE), the Nevada Division of Environmental Protection (NDEP), and the U.S. Department of Defense (DoD). The purpose and scope of the CAI are presented in this section, followed by a summary of the entire document. The term "CAU model" as used in this document means "groundwater flow and contaminant transport model for the Frenchman Flat CAU". Any other types of models referred to in this document are explicitly stated.

\subsection{Purpose}

Based on the general definition of a CAI from Section IV.14 of the FFACO, the purpose of the CAI is “...to gather data sufficient to characterize the nature, extent, and rate of migration or potential rate of migration from releases or discharges of pollutants or contaminants and/or potential releases or discharges from corrective action units identified at the facilities..." (FFACO, 1996). However, for the Underground Test Area (UGTA) CAUs, “...the objective of the CAI process is to define boundaries around each UGTA CAU that establish areas that contain water that may be unsafe for domestic and municipal use.", as stated in Appendix VI of the FFACO (1996). According to the UGTA strategy (Appendix VI of the FFACO), the CAI of a given CAU starts with the evaluation of the existing data. New data collection activities are generally contingent upon the results of the modeling and may or may not be part of the CAI. Such is the case for the Frenchman Flat CAU. 


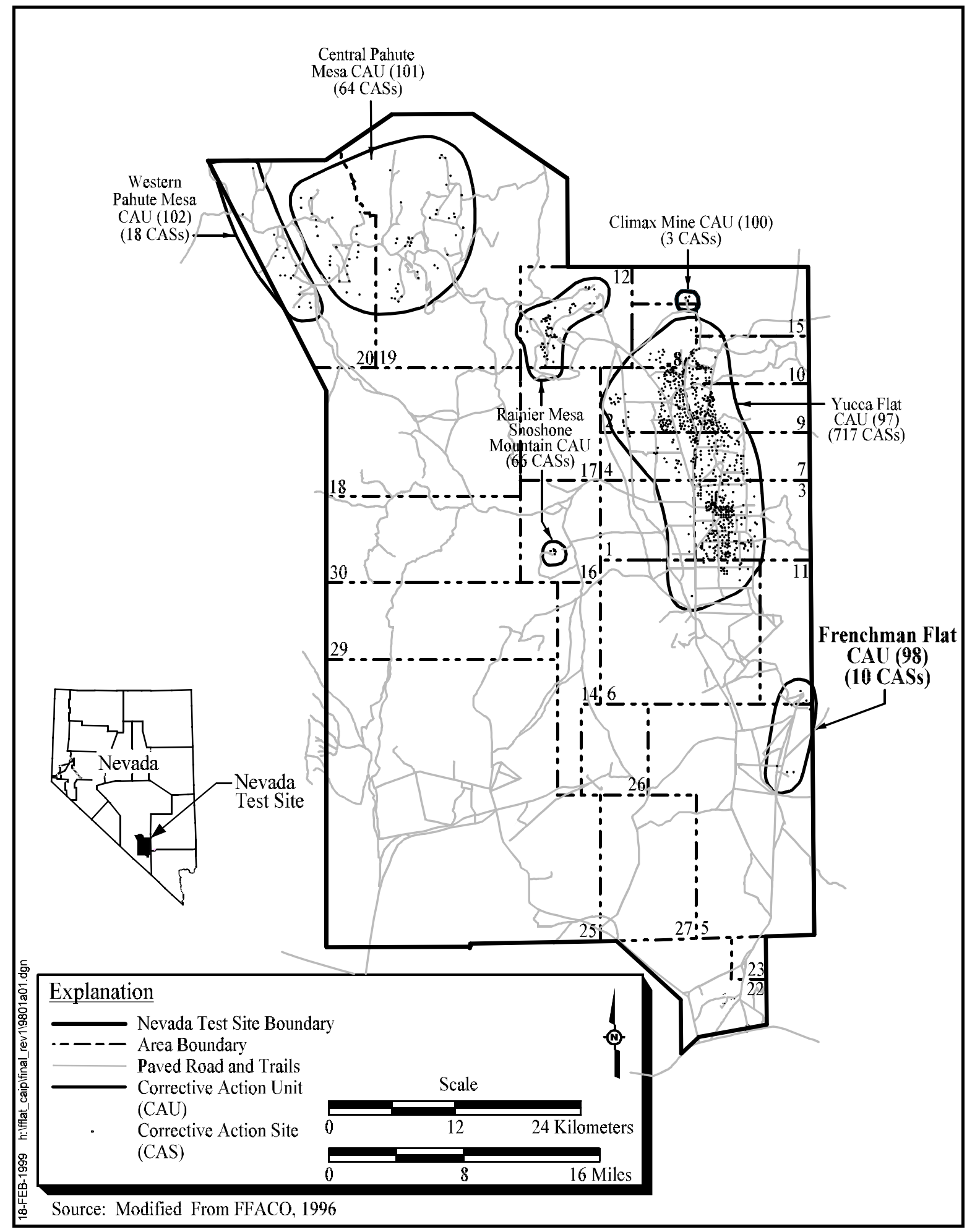

Figure 1-1 Location of the Frenchman Flat Corrective Action Unit 
Specific objectives of the Frenchman Flat CAI are as follows:

- Determine the characteristics of the groundwater flow system, the sources of contamination, and the transport processes to acceptable levels of uncertainty.

- Develop a credible numerical model of groundwater flow and contaminant transport for the Frenchman Flat CAU and downgradient areas

- Develop stochastic predictions of the contaminant boundary at an acceptable level of uncertainty

\subsection{Scope}

The current scope of the Frenchman Flat CAI includes the development and use of a three-dimensional (3-D), numerical, CAU-scale groundwater flow and contaminant transport model to predict the location of the contaminant boundary. The CAU model will be developed and used to predict the location of the contaminant boundary. Modeling activities include code selection, assessment of existing and newly-acquired data, model development, model verification, and prediction of the contaminant boundary. The scope of this CAI does not currently include any characterization activities; however, such activities will be conducted if the CAU model results indicate that further characterization information is needed to develop a sufficiently reliable CAU model. If it is decided that such activities are needed, they will be presented to NDEP in an addendum to this CAIP.

Two areas of importance to the CAU model are the model area and the investigation area. The CAU-model area will be selected to encompass the Frenchman Flat CAU and the region located immediately downgradient where contamination may migrate. The extent of the CAU-model area is dependent on the extent of contamination and is uncertain at this point. Currently, the potential CAU-model area extends from Massachusetts Mountain to the north, to the edge of the alluvium to the south, and from the Range Mountains in the east, to Mount Salyer to the west (Figure 1-2). The extent of the CAU-model area will be finalized after the data have been assessed. DOE/NV will inform NDEP of any significant increase in the model area. The investigation area encompasses the CAU-model area and is defined as the region over which data will be collected from the literature and summarized for possible inclusion in the CAU model. The investigation area extends from southern Yucca Flat to the southern NTS area, including Mercury (Figure 1-2). This area is intentionally large 


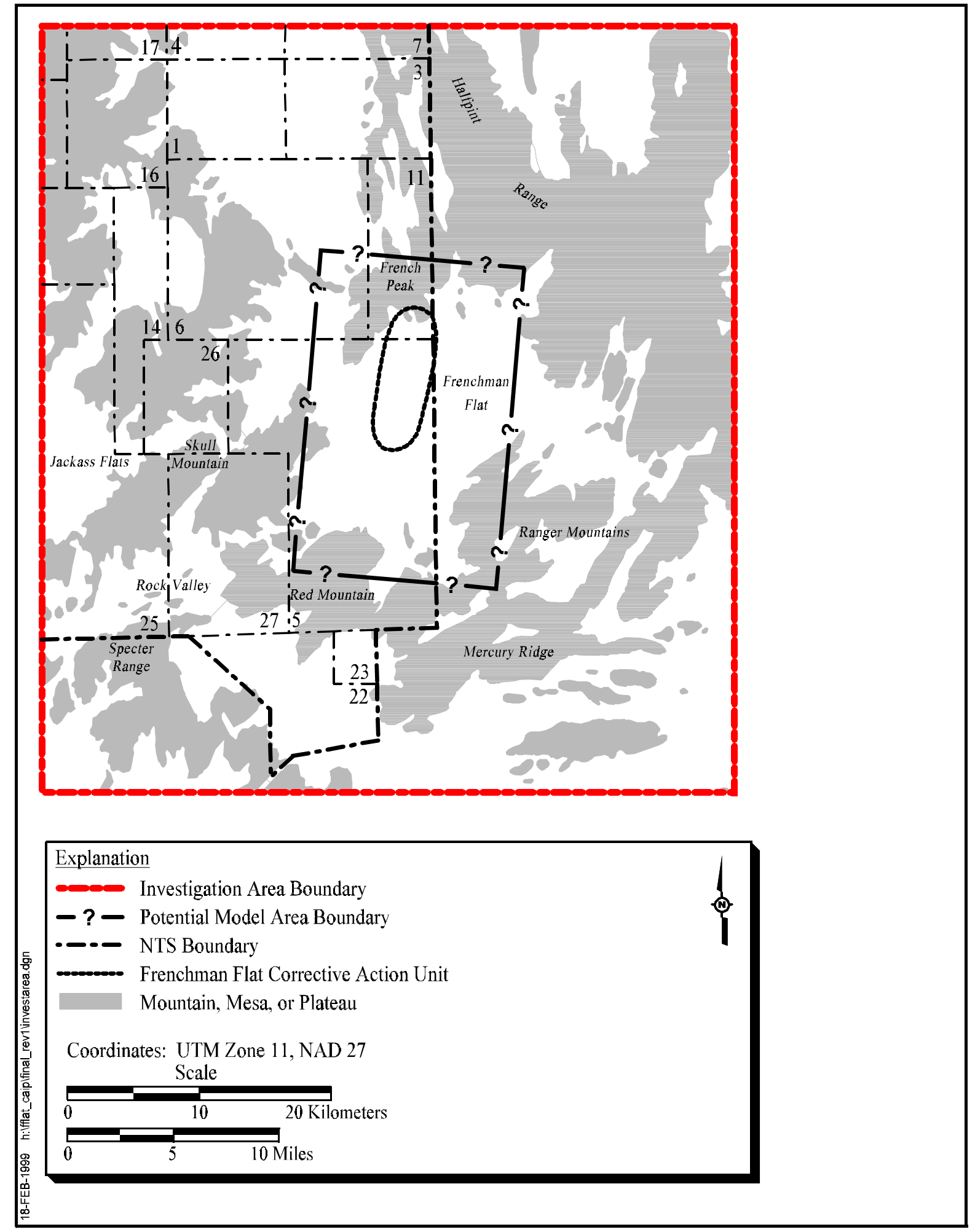

Figure 1-2 Location of Frenchman Flat Investigation and Potential Model Areas 
to include all possible pathways for radionuclide migration from the Frenchman Flat CAU. In addition, when updates to databases are requested, it is better to ask for a larger area rather than to repeat data requests several times. The extent of the investigation area is not expected to increase during the CAI.

\subsection{Summary of the CAIP}

This section includes an overview of the CAIP's technical elements followed by a summary of the contents of the CAIP.

\subsubsection{Overview of Technical Elements of the CAIP}

The Frenchman Flat CAI will be conducted by DOE/NV with close involvement of NDEP throughout the process. The CAI will be conducted in four major sequential steps designed to be consistent with the UGTA strategy described in Appendix VI of the FFACO (1996) and summarized in Section 2.1.2 of this document. Figure 1-3 summarizes the four major steps and references the sections of the CAIP in which they are discussed. Documents which will be generated to report on the technical findings of the CAI are also presented in this section.

\subsubsection{Assessment of CAU-Related Data}

At the initiation of the CAI, the relevant data will be compiled, evaluated, and used to refine the current conceptual groundwater flow and contaminant transport model. The data described in Section 3.0 will be supplemented with historical data acquired from public and private sources, and data from on-going monitoring programs. All relevant published and unpublished existing data will be considered. The necessary data types have been subdivided into two categories: data for the groundwater flow model and data for the contaminant transport model. The data assessment activities are described in Section 5.1.3.

\subsubsection{Development of CAU Model}

The refined conceptual model and all data will then be used to develop a transient three-dimensional groundwater flow and contaminant transport model. The CAU model development process includes several steps: code selection, groundwater flow model construction, contaminant transport model construction, sensitivity analyses, uncertainty analyses, and peer review. The procedure used to develop the groundwater flow and contaminant transport model is detailed in Section 5.1.4 through 


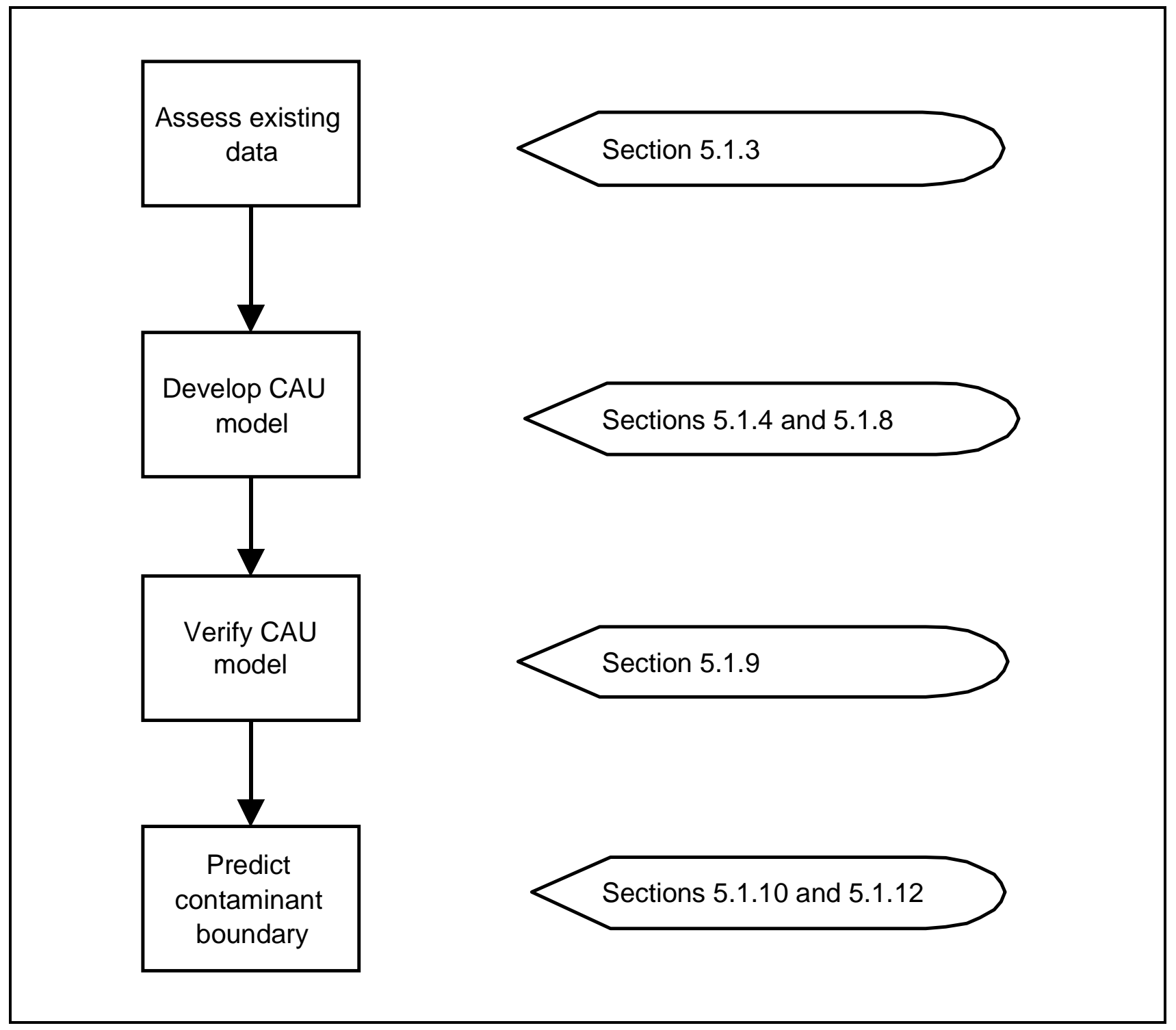

Figure 1-3

Overview of the Technical Elements of the Frenchman Flat CAIP 
5.1.8. Other models supporting the CAU-scale groundwater flow and transport model are described in Section 5.2.

\subsubsection{Verification of CAU Model}

When the CAU model is completed, it will be reviewed by a peer review panel, DOE and NDEP. If DOE and NDEP do not reject the CAU model, a model verification plan will be prepared and submitted to NDEP as an addendum to this CAIP. Once the CAU-model verification plan is approved, it will be implemented. In the event that the CAU model is rejected, DOE and NDEP will initiate discussions to identify the appropriate path forward. Activities relating to the CAU-model verification are detailed in Section 5.1.9.

\subsubsection{Prediction of Contaminant Boundary}

The CAU model will then be used to simulate a contaminant boundary which will be proposed by DOE and negotiated with NDEP. A postaudit of the CAU model results will be performed to verify the validity of the CAU model results during the five year proof-of-concept period. These steps are explained in Section 5.1.10 and 5.1.12.

\subsubsection{CAI Documentation}

The Frenchman Flat CAI activities will be reported in three documentation packages, a CAU-model report and the Corrective Action Decision Document (CADD) as follows:

- Volume I will document the assessment of geologic data and describe the resulting hydrostratigraphic model.

- Volume II will document the assessment of groundwater data including hydrogeologic data, contaminant transport data.

- Volume III will document the results of the modeling process.

- The CAU model report will summarize the contents of the three documentation packages.

- The CADD is an FFACO document which will discuss the findings of all CAI activities, including the CAU model, its verification, and the contaminant boundary predictions. In addition, the CADD will describe the corrective action alternatives considered and the selected alternative. 


\subsubsection{Document Organization}

As required by the FFACO (1996), this CAIP provides or references the specific information used for planning the investigation activities associated with the Frenchman Flat CAU. Specific information required by the FFACO (1996) and provided or referenced in this CAIP includes: management, technical aspects, quality assurance, health and safety, and public involvement. This document consists of nine sections and one appendix, summarized as follows:

- Section 1.0 describes the purpose and scope of the Frenchman Flat CAI and presents a summary of the contents of this CAIP.

- Section 2.0 describes how the proposed CAIP will be planned and conducted in accordance with the requirements of the FFACO. This section also lists other applicable or potentially applicable regulations.

- Section 3.0 provides a description of the Frenchman Flat CAU. The section includes descriptions of the investigative background of the CAU, the operational history, the corrective action sites, the physical setting based on available information, the contaminants, the conceptual model of the CAU, and the preliminary corrective action levels for the contaminants of concern.

- Section 4.0 discusses the results of the data quality objective (DQO) process and relates the proposed conceptual model and the identified migration scenarios to these results.

- Section 5.0 describes the groundwater flow and transport modeling activities to be completed for the CAI. Supporting models are also described.

- Section 6.0 provides a discussion of any additional characterization activities which are anticipated or justification for no additional characterization.

- Section 7.0 identifies the quality assurance and quality control requirements for the completion of the CAI. References to the appropriate plans are included.

- Section 8.0 contains a description of the project schedule and records availability information.

- Section 9.0 provides a list of references used to prepare the CAIP.

- Appendix A contains a detailed discussion of the DQO process. The specific approach used for the Frenchman Flat CAU and the DQO process results are described. 
The managerial aspects of this project are discussed in the DOE/NV Environmental Restoration Project (ERP), Project Management Plan, Rev. 0 (DOE/NV, 1994a). No CAU-specific public involvement activities are planned at this time; however, an overview of public involvement is documented in the Public Involvement Plan in Appendix V of the FFACO (1996). 


\subsection{Legal/Regulatory Requirements}

The DOE, Defense Threat Reduction Agency, and the NDEP have negotiated a FFACO to address environmental restoration activities at DOE/NV facilities and sites. The FFACO is the regulatory driver for DOE environmental restoration activities in Nevada. Part III of the FFACO (1996) identifies the legal authorities under which the DOE and NDEP entered into the agreement. The FFACO is discussed in this section.

\subsection{Federal Facility Agreement and Consent Order}

This section includes a summary of the FFACO requirements and the UGTA corrective action strategy as described in the FFACO (1996). The application of the strategy to the Frenchman Flat CAU is also presented.

\subsubsection{FFACO Requirements}

General and specific FFACO requirements that are applicable to the UGTA Subproject including Frenchman Flat are discussed in this section.

\subsubsection{General Requirements}

The FFACO sets the framework for prioritizing environmental restoration of contaminated DOE/NV facilities and sites. The FFACO also contains the regulations that will govern restoration activities, and provides the mechanism to enforce them. Technical strategies for restoration activities are also provided in the FFACO.

The DOE, through the UGTA Project, is responsible for completing corrective actions for six CAUs associated with historical underground nuclear testing on the NTS (Figure 1-1). The Frenchman Flat CAU is included in this group of CAUs.

The FFACO requires that several plans and reports be prepared to document the corrective action process. These documents provide details about the activities needed to ensure the completion of the corrective action. Documents that are applicable to UGTA CAUs include the following: 


\section{Corrective Action Investigation Plan (CAIP)}

This is a required planning document that provides or references specific information for planning investigation activities associated with corrective action units or sites.

\section{Corrective Action Decision Document (CADD)}

This is a required report that documents the CAI. It describes the selected corrective action and the rationale for its selection.

\section{Corrective Action Plan (CAP)}

This is a required planning document that describes the corrective action implementation plan. It also explains the corrective action completion process.

\section{Closure Report}

This required report documents the corrective action completion process to verify that the corrective action was conducted in accordance with the approved CAP. It also provides all necessary supporting information and information on post closure monitoring.

\section{Notice of Completion}

This is a state-issued document marking the completion of the corrective action in accordance with the approved plans.

\subsubsection{Specific Requirements}

The Frenchman Flat CAI will be planned and conducted in accordance with the appropriate investigation purposes of the FFACO (1996) as outlined in Subparts II.1.b.ii, II.1.c, as well as the requirements of Subparts IV.14 and IV.15. Each of these specific subparts of the FFACO are quoted below, followed by a description of how their requirements are being fulfilled during the CAI.

- II.1.b. "Establishing specific sampling and monitoring requirements, including drilling and subsurface sampling, designed to:" 
- II.1.b.ii. "Determine whether releases of pollutants and/or hazardous wastes or potential releases of pollutants and/or hazardous wastes are migrating or potentially could migrate, and if so, identify the constituents, their concentration(s), and the nature and extent of that migration."

In accordance with Subpart II.1.b.ii., a near-field and a CAU-scale groundwater flow and contaminant transport models will be developed to evaluate whether releases and migration of contaminants are occurring based on the existing data. The CAU-scale groundwater flow and transport model will also be used to determine whether additional data are needed to reduce the uncertainties associated with the CAU model predictions of contaminant migration. Modeling activities planned in the CAI are described in Section 5.0. Provisions for collecting additional data are described in Section 6.0. Also, in accordance with this subpart, a preliminary list of contaminants is provided in Section 3.5. A description of the nature and extent of the contaminant migration based on the current information is presented in Section 3.6.

- II.1.c. "Providing all parties with sufficient information to enable adequate evaluation of appropriate remedies by specifying the radioactive and hazardous constituents for each CAU."

As required by FFACO Subpart II.1.c., a preliminary list of radioactive and hazardous constituents for the Frenchman Flat corrective action unit is provided in Section 3.5 of this document. This list provides all parties with sufficient information to enable adequate evaluation of appropriate remedies and will be updated based on the findings made during the CAI.

- IV.14. "Corrective action investigation (CAI) shall mean an investigation conducted by DOE and/or DoD to gather data sufficient to characterize the nature, extent, and rate of migration or potential rate of migration from releases or discharges of pollutants or contaminants and/or potential releases or discharges from CAUs identified at the facilities."

The Frenchman Flat CAI will initially consist of developing a groundwater flow and contaminant transport model using the existing data to estimate the extent of contamination. If the modeling results are not satisfactory to DOE and NDEP, DOE and NDEP will evaluate whether the strategy is achievable.

- IV.15. "Corrective action investigation plan (CAIP) shall mean a document that provides or references all of the specific information for planning investigation activities associated with CAUs or corrective action sites (CAS). A CAIP may reference information in the optional 
CAU work plan or other applicable documents. If a CAU work plan is not developed, then the CAIP must include or reference all of the management, technical, quality assurance, health and safety, public involvement, field sampling, and waste management information needed to conduct the investigations in compliance with established procedures and protocols."

In accordance with FFACO Subpart IV.15, this CAIP provides or references all of the specific information for planning investigation activities associated with the Frenchman Flat Corrective Action Unit. This CAIP includes or references all of the management, technical, quality assurance, health and safety, public involvement, field sampling, and waste management information needed to conduct the investigations in compliance with established procedures and protocols as described in Section 1.0.

All information provided in this CAIP is based on the current state of knowledge and will be updated following completion of the CAI. The results will be reported in the CADD.

\subsubsection{Corrective Action Strategy}

A summary of the UGTA strategy negotiated by DOE and NDEP for UGTA (FFACO, 1996) is presented in the first part of this section. The DOE and NDEP will work together throughout the implementation of the strategy for each of the UGTA CAUs, including the Frenchman Flat CAU. Upon approval of the CAIP and at the beginning of each fiscal year in which the CAI will be conducted, DOE will inform NDEP of all planned activities for the CAI. The DOE will facilitate any visits or meetings requested by NDEP to evaluate the CAI process presented in Section 5.0. The DOE will also identify when products will be available for transmittal to NDEP. The details of the implementation of the UGTA strategy is described in the second part of this section.

\subsubsection{Description of Corrective Action Strategy}

As stated on page VI-3-3 of Appendix VI of the FFACO, "the objective of the CAI process is to define boundaries around each UGTA CAU that establish areas that contain water that may be unsafe for domestic and municipal use". The definition of such contaminant boundary is provided, followed by descriptions of the development and implementation of a corrective action, and of the closure of a CAU. 


\subsection{General Definition of Contaminant Boundary}

The contaminant boundary has been defined in Appendix VI of the FFACO (1996) as follows:

"CAU models utilizing tritium as the source term will be used to establish the contaminant boundary for each CAU. The boundary will be composed of a perimeter boundary and a lower hydrostratigraphic unit boundary. The perimeter boundary will define the aggregate maximum extent of contamination transport at or above the concentration of concern for the CAU. The lower hydrostratigraphic unit boundary will define the lowest aquifer unit affected by the contamination. Long-lived radionuclides, besides tritium, will be included to evaluate the relative extent of migration of different radionuclides in the future. If it is predicted that another radionuclide will migrate farther than tritium at concentrations of concern, the contaminant boundary will include that prediction."

Also, as explained in the FFACO (1996), uncertainties will be associated with the contaminant boundary predictions using the CAU models (FFACO, 1996). These uncertainties can be expressed as confidence levels as shown on Figure 2-1 and explained in Appendix VI of the FFACO (1996):

"Each contour reflects an increased level of confidence that no contaminants exceeding a given regulatory concentration will ever cross that boundary.

As confidence increases, the distance from the CAU increases. The confidence levels could lead to the development of different contaminant boundaries, depending on the degree of certainty decision makers need to select appropriate controls."

The distance from the source of contamination (the CAU in Figure 2-1) to the contaminant boundary increases as the confidence level increases.

\subsection{Process Description}

The UGTA strategy is outlined in the decision diagram on Page VI-3-6 of Appendix VI of the FFACO (1996) (Figure 2-2). The shaded portion of the diagram illustrates the portion of the process that takes place during the CAI. The UGTA strategy is based on two principal assumptions. The first assumption is that the strategy can be achieved by using existing data and wells. The second assumption is that the proposed remedial option is long-term monitoring. The strategy does allow for deviations should these assumptions prove to be incorrect.

The first step in the strategy is to collect, assess, and evaluate the existing geologic, hydrologic, and radionuclide information available for each CAU. If DOE determines that sufficient data exist, then a 


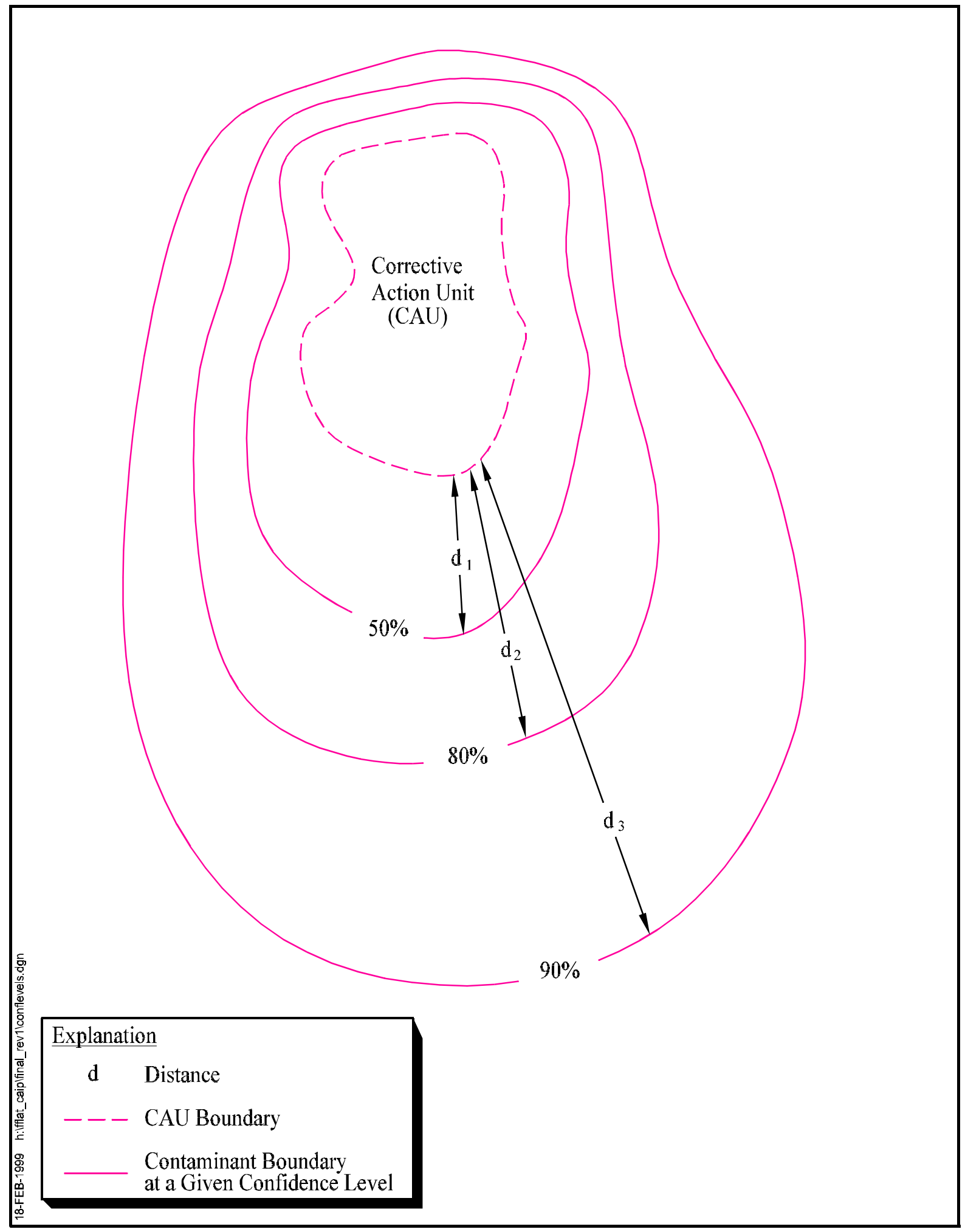

Figure 2-1

\section{Example of Contaminant Boundary Confidence Levels}




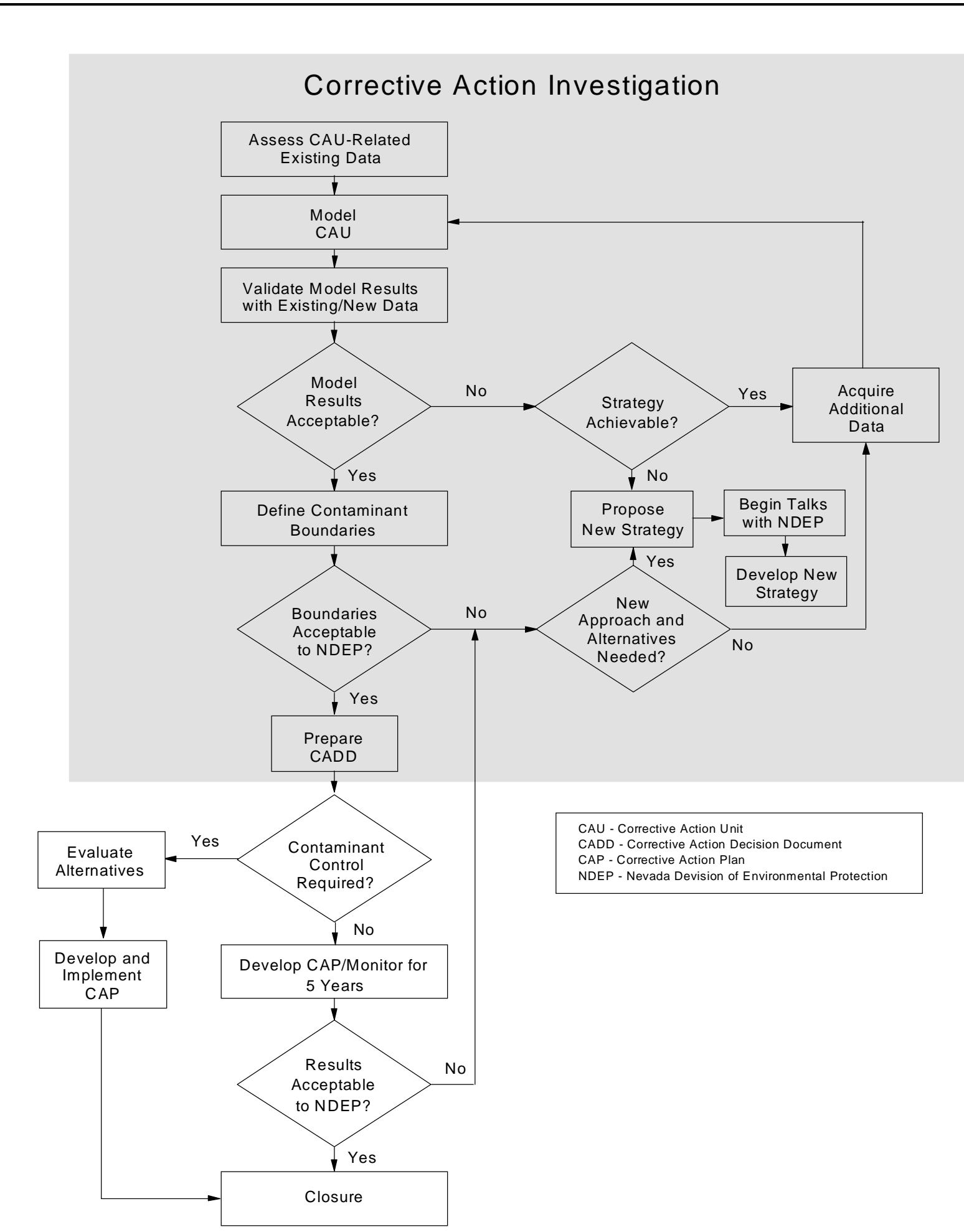

Figure 2-2

Decision Diagram for the Underground Test Area 
groundwater flow and contaminant transport model will be developed utilizing these data. If sufficient data do not exist, then DOE can propose to collect additional data prior to developing the CAU model.

The second step consists of developing a three-dimensional groundwater flow and contaminant transport model to define the maximum extent of contaminant transport for the CAU. Tritium and all other radionuclides that are longer lived will be evaluated to establish the contaminant boundary for each CAU.

The contaminant boundary will define the maximum extent of contamination in the horizontal direction as well as the lowest aquifer unit affected, as specified in the FFACO (1996) and described in Section 2.1.2.1.1. When the modeling is completed, the CAU model will be presented to DOE/NV and NDEP and evaluated by a peer review panel. If the CAU model is not rejected by DOE/NV and NDEP, it will be verified, and the simulated contaminant boundary will be proposed by DOE/NV and negotiated with NDEP.

If the CAU model is rejected or the contaminant boundary cannot be agreed upon between DOE and NDEP, then DOE and NDEP will determine if the strategy, as defined in the FFACO (1996) is achievable. If the strategy can be achieved, DOE will collect additional data. The new data will then be used in the CAU model, and the process will be repeated. If it is determined that the strategy is not achievable, negotiations will be initiated to develop a new strategy.

After the contaminant boundary has been defined and accepted, DOE will evaluate various remedial alternatives and propose a corrective action. The modeling results, contaminant boundary, and proposed corrective action will be documented in the CADD and submitted to NDEP for approval. After approval of the CADD, a CAP will be developed to implement the corrective action. If the corrective action is intrinsic remediation with long-term monitoring, a five-year proof-of-concept period will be initiated. This proof-of-concept period will allow DOE and NDEP time to determine if the monitoring results support the CAU model. If the monitoring results are acceptable, a closure plan will be developed for the CAU. If the results are not acceptable, then DOE and NDEP will need to determine if the strategy is achievable. 


\subsubsection{Implementation of the Corrective Action Strategy}

The DOE's approach for implementing the FFACO strategy for the UGTA CAUs is described in this section. The approach is described in terms of the specific definition of the contaminant boundary, corrective action investigation, correction action implementation, and CAU closure.

\subsection{Specific Definition of the Contaminant Boundary}

The specific definition of the contaminant boundary is risk-based. The contaminant boundary is defined as the maximum extent of contamination defined as a human dose of 4 millirems per year (mrem/yr) for radionuclides or a concentration equal to drinking water standards (maximum contaminant levels) for other contaminants, at the 50 percent confidence level within a 1,000-year. The 4-mrem/yr dose regulatory limit is based on the Clean Water Act (USC, 1996a), and may include multiple contaminants. The total dose is the sum of the doses of all contributing radionuclides using a drinking water scenario (Adams, 1996a and b). The individual contributions from each contaminant to the dose must be less than the regulatory limit.

\subsection{Corrective Action Investigation}

The CAI is led by the DOE UGTA project manager. A Technical Working Group (TWG) was formed to assist the DOE UGTA project manager with technical management issues. The Technical Working Group consists of representatives from the participating organizations which are Bechtel Nevada (BN), Desert Research Institute (DRI), IT Corporation (IT), Lawrence Livermore National Laboratory (LLNL), Los Alamos National Laboratory (LANL), and the U.S. Geological Survey (USGS). The TWG serves as a technical advisory group to the DOE UGTA Project Manager. Tasks assigned to the TWG committee include providing technical recommendations to DOE, providing expert technical support in specific UGTA tasks via subcommittees, and serving as internal peer reviewers of UGTA products. The CAI consists of two major phases: planning and implementation. Both the planning and implementation of the CAI rely on the use of the regional groundwater flow and contaminant transport model presented in the Regional Groundwater Flow and Tritium Transport Modeling and Risk Assessment of the Underground Test Area (regional model) (DOE/NV, 1997). The two phases of the CAI are described in the following sections. Descriptions of how the regional model is used during the CAI are also provided. 


\section{CAI Planning}

As stated in the FFACO strategy and in Section 2.1.2.1 of this document, the scope of the CAI consists of developing a CAU model with existing data and predicting the location of the contaminant boundary. However, to ensure that no additional data are warranted, the CAI is planned using the DQO process, which ensures that the type, quantity, and quality of environmental data used in the decision-making process are appropriate for the intended application (EPA, 1993). To support the DQO process, the regional model is used to identify areas of uncertainties associated with the groundwater flow system and transport processes of a given CAU. In addition, a Value of Information Analysis (VOIA) is performed to support the DQO process. The VOIA is a management tool intended to help decision makers evaluate cost-effective, information-collection options to reduce existing uncertainties.

During the VOIA, results of the transport simulations performed using the regional model were used to identify sensitive parameters. An input parameter is said to be sensitive if a given change in its value causes a large change in the model results. Conversely, a parameter is said to be insensitive, if a given change in its value causes little change in the model results. Transport simulations used include the tritium transport simulations described in the regional modeling report (DOE/NV, 1997) and the results of transport simulations for other radionuclides of concern. The radionuclides of concern were identified by the source term subcommittee of the UGTA Technical Working Group. Based on the regional modeling results, another subcommittee, formed specifically for the VOIA, proposes various data collection options. This group then estimates how much each of the data collection options will reduce the uncertainty in the regional model results. This estimated reduction in uncertainty is then combined with the estimated cost of the data collection option, and a cost-benefit analysis is performed on all the options.

The results of the VOIA are then used to evaluate the benefit of collecting additional data prior to developing the CAU model. The UGTA Subproject Manager uses the results of the regional model and those of the VOIA to design characterization activities to collect the appropriate data for the CAU model. Upon review of the VOIA results, the Technical Working Group recommended that additional data collection activities were not necessary prior to the development of the Frenchman Flat CAU model. 
The VOIA process and results are documented in a report (IT, 1997c). The DQO process is documented in the CAIP. The CAIP also provides a description of the CAU, its history, the physical setting, the contaminants, and the conceptual model of the CAU. The CAIP will discuss the process for developing the CAU model and describe, if necessary, any data collection activities.

\section{CAI Implementation}

If, during the planning process, it is decided that no new data are necessary to develop the CAU model, the CAI is initiated with the modeling activities. The modeling process consists of model selection; model development including data assessment; model verification; and contaminant boundary prediction. The process begins with the selection of the groundwater flow and transport code, based on a predefined set of criteria. Several candidate codes have been identified for potential use in the UGTA Project (IT, 1998). Three codes will be selected for further evaluation. These codes will be tested using a sample problem, and the results of this test will lead to the selection of the code to be used. The CAU model must have the ability to represent the important physical and chemical features of the CAU flow system. These features include faulting, stratigraphy, sources and sinks of water, the distribution of contaminants and their rates of introduction into the flow system, and other physical and chemical features unique to the CAU. The CAU model must also be able to simulate the movement of a variety of contaminants and possess the flexibility to allow grid changes and model boundary condition variations.

Existing geologic and hydrologic data are then compiled and evaluated, and a geologic model is constructed using these data, including surface and subsurface geologic and geophysical data obtained from boreholes within or near the geologic model boundary. This geologic model, along with the hydrologic data, is then used to develop the groundwater flow model. The regional groundwater flow model is used to define boundary conditions and initial estimates of recharge for the CAU-scale groundwater flow model. Hydraulic conductivity data obtained from aquifer tests conducted in the CAU or the surrounding region are used to define an initial distribution. Water level information from boreholes in and near the CAU are used to calibrate the CAU groundwater flow model. After completion of the CAU groundwater flow model, the CAU transport model is developed. The primary input parameters to the CAU transport model are effective porosity, matrix porosity, matrix diffusion, fracture information, dispersivity, source term, and sorption. Effective 
porosity and dispersivity values are derived from tracer tests conducted in the area. Matrix diffusion is determined from laboratory studies conducted on core samples, and source term information is obtained from cavity water samples collected from the hot well monitoring network, unclassified source term data and other analyses performed to estimate the source term. Sorption parameters are derived from laboratory studies and tracer tests in the area and may be supplemented from studies outside Nevada as described in Section 3.0.

After the groundwater flow and transport model is developed, sensitivity and uncertainty analysis will be performed. This will also include evaluating the impacts of alternate geologic interpretations. The CAU model will then be presented to NDEP and a peer review panel for review and comment. The comments will be incorporated, as necessary, to produce an acceptable CAU model. Based on the CAU model results, a proposal will then be presented to NDEP for validating the CAU model.

The CAU model will be used to predict the location of the contaminant boundary. Various remedial alternatives will be evaluated and a recommendation made based on the established boundaries. If the recommendation is long-term monitoring, a monitoring network will be designed.

If, anytime during the process, it is determined that additional data are needed, a plan for collecting the information will be prepared. This plan will identify the types of data required and describe the work proposed to collect this information, which will then be used to develop the CAU model.

The results of the modeling effort, data collection activities, and the evaluation of remedial alternatives will be documented in the CADD and presented to NDEP for approval.

\subsection{Corrective Action Implementation and CAU Closure}

After the CADD has been approved, a CAP will be written describing how DOE will implement the corrective action. If monitoring is the decision, the CAP will describe the work for installing new wells, if necessary, and the monitoring parameters and schedule for the five-year proof-of-concept period.

After successful implementation of the corrective action, the CAU will be proposed for closure and documented in a report. 


\subsection{Description of the Corrective Action Unit}

This section includes a description of the Frenchman Flat corrective action unit. The investigative background and operational history of the area are presented first. The corrective action sites are then listed along with their specific attributes. Descriptions of the physical setting, contaminants, and conceptual model of the CAU are then provided based on a preliminary evaluation of the existing information. Finally, the preliminary action levels for the major potential contaminants considered in this CAI are presented.

\subsection{Investigative Background}

This description of the investigative background of the Frenchman Flat CAU is based mainly on the results of the data assessment performed during the regional evaluation (DOE/NV, 1997). A preliminary CAU-specific data assessment was also performed to include some of the recent relevant investigations. To ensure that all relevant information is available for inclusion in the CAU model at the initiation of the CAI, a thorough assessment of the existing data will be conducted during the CAI as described in Section 5.1.3.

Investigations of the geology and hydrogeology of Frenchman Flat and the surrounding region have taken place from the early 1950 s to the present. These studies have ranged in scope from investigations that encompass all of the NTS, to studies of individual exploratory holes associated with specific tests in Frenchman Flat. Investigative methods have included geologic mapping, geophysical logging, analysis of water chemistry, and hydraulic testing.

On a regional basis, geologic information was obtained from the Nevada state geologic map, Stewart and Carlson (1978) as well as several studies which covered the NTS and surrounding areas (Sinnock (1982); Ponce et al. (1988), and Wahl et al., 1997). These studies provided stratigraphic and structural geologic data on a regional basis. Using the data from these sources as well as others, IT in cooperation with several other organizations, developed a regional geologic model for the NTS (IT, 1996d). Other studies have provided geologic data related to specific areas of Frenchman Flat including: Blout et al. (1994); Carr et al. (1975); Drellack, Jr. (1995b); Grauch and Hudson (1995); Poole (1964 and 1965); and Reynolds Electrical \& Engineering Co., Inc. (1994). In addition to these studies, geologic maps have been prepared for all the topographic quadrangles within the Frenchman 
Flat study area. Detailed geologic logs and stratigraphic data are available from several studies of individual exploratory drill holes associated with specific nuclear tests conducted in Frenchman Flat: Byers, Jr., and Miller (1966); Dixon et al. (1965 and 1967); Fernald et al. (1965); Houser (1962); Howard (1976); Meyer and Young (1962); Miller et al. (1967); Ramspott and McArthur (1977); and Prather (1965). Although these studies provide very detailed information, they were limited to the depth of the particular borehole being logged, which in most cases, was terminated in the unconsolidated alluvial material.

The hydrogeologic studies also ranged from specific areas of Frenchman Flat to regional in scope. Such studies include those of Arteaga et al. (1991); Borg et al. (1976); Buddemeier (1988); Buddemeier et al. (1989); Chapman et al. (1995); Eakin et al. (1951); Marsh (1991 and 1992); Winograd and Thordardson (1975). Another source of information is the NTS regional model (DOE/NV, 1997; IT, 1996a through f; IT, 1997a and b). This regional model was developed to evaluate the NTS underground test areas including Frenchman Flat. Some hydrologic studies were conducted within Frenchman Flat at exploratory drill hole locations: Prather (1965) and Meyer and Young (1962). As noted with the site-specific geologic studies, the hydrologic studies completed at exploratory drill hole locations were limited to providing data within the unconsolidated alluvial material and volcanic units. No hydrologic information was provided for the deeper bedrock units except at the edges of the flat. Some data are available regarding water levels, although the number of well locations in the Frenchman Flat CAU is limited and the depth of the wells is usually restricted to the unconsolidated alluvial aquifer (IT, 1996c and Claassen, 1973).

The majority of groundwater chemistry data are related to sitewide studies such as: Borg et al. (1976); Daniels, ed. (1981, 1982, 1983); Daniels and Thompson (1984); Thompson, ed. (1991); and Marsh, ed. (1992 a and b). Site-specific water chemistry data are mostly related to the CAMBRIC experiment which began in 1974 and was completed in 1991. CAMBRIC experiment studies included: Hoffman et al. (1977); Bryant (1992a); and Travis et al. (1983).

Although some studies have dealt with migration of various radionuclides, no assessment of human health risk has been completed for the Frenchman Flat area. A regional risk assessment of the UGTA was completed in 1997 (DOE/NV, 1997). 
Two documents that address National Environmental Policy Act (NEPA) requirements for activities at the NTS are the site-wide Environmental Impact Statement (DOE/NV, 1996c) and an UGTA Subproject-specific Environmental Assessment (DOE/NV, 1992). It is anticipated that NEPA requirements will not impact the Frenchman Flat CAI, because, at present, no field investigation is planned (Section 6.0).

\subsection{Operational History}

A chronology of the underground nuclear tests conducted in Frenchman Flat is presented. For the purposes of reporting, the tests were grouped on a fiscal-year basis and a different operation code name was assigned to each fiscal year (DOE/NV, 1994b). The discussion includes the type of tests that were detonated, their purpose, their yield range, and their depths of burial.

The term "type of test" refers to the method of deployment of the nuclear device at the time of detonation. The term "yield range" refers to the total effective energy released in a nuclear explosion and is usually expressed in terms of equivalent tonnage of trinitrotoluene (TNT) required to produce the same energy release in an explosion. A kiloton (kt) yield range represents the energy of a nuclear explosion that is equivalent to the explosive power of 1,000 tons of TNT (DOE/NV, 1994b).

The operational history of Frenchman Flat as an underground nuclear testing area of the NTS covers a 7-year time span. A total of ten tests were conducted between 1965 and 1971. Nuclear testing on Frenchman Flat began with Operation Whetstone in 1965 and ended with Operation Grommet in 1971 (DOE/NV, 1994b). All nuclear tests conducted in Frenchman Flat were detonated in deep shafts, drilled into alluvial and volcanic rock above or below the water table. All underground nuclear tests conducted in Frenchman Flat, except for two, have yield ranges specified as "less than $20 \mathrm{kt} "$.

Underground nuclear tests in Frenchman Flat were part of the weapons development program. All nuclear tests conducted in Frenchman Flat were weapons-effects tests except for the CAMBRIC test which was a weapons-related test. Weapons-effects tests were usually conducted by the DoD to evaluate the effects of nuclear detonations on military systems (DOE/NV, 1994b). Weapons-related tests were conducted to gather data on nuclear devices. All underground nuclear tests in Frenchman 
Flat were conducted in shafts. Shaft nuclear devices were exploded at the bottom of a drilled or mined vertical hole (DOE/NV, 1994b).

The first series of underground nuclear tests detonated in Frenchman Flat in 1965 include WISHBONE, CAMBRIC, and DILUTED WATERS under Operation Whetstone. WISHBONE, a DoD Test, was detonated on February 18, 1965 at 175 meters $(\mathrm{m})$ (574 feet [ft]) below ground surface (bgs) and CAMBRIC was detonated on May 14, 1965 at 295 m (968 ft) bgs. DILUTED WATERS, a

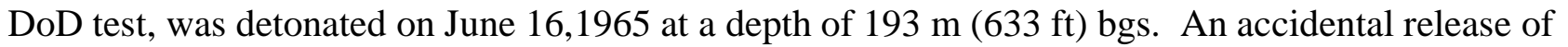
radioactivity to the surface was detected on site only following the WISHBONE test. An on-site release refers to an unplanned release of radioactivity into the atmosphere that was not detectable beyond the boundaries of the Test Range Complex, which includes the NTS and the Nellis Air Force Range. An off-site release was detected following the DILUTED WATERS test (DOE/NV, 1996b).

An off-site release refers to an unplanned release of radioactivity into the atmosphere that was detected any place outside the Test Range Complex.

The second series of tests detonated in 1966 include PIN STRIPE and DERRINGER under Operation Flintlock. PIN STRIPE was conducted on April 25, 1966 at a depth of $296 \mathrm{~m}(971 \mathrm{ft}) \mathrm{bgs}$ and DERRINGER was conducted on September 12,1966 at a depth of $255 \mathrm{~m}$ (837 ft) bgs. Accidental releases of radioactivity were detected off-site following both of these tests (DOE/NV, 1996b). NEW POINT (DoD test) was detonated on December 13, 1966 under Operation Latchkey. An accidental on-site release to the surface also occurred during this test.

After NEW POINT, underground nuclear testing on Frenchman Flat stopped and did not resume until March 25, 1968, when the MILK SHAKE test was detonated, under Operation Bowline. MILK SHAKE was detonated at $265 \mathrm{~m}(869 \mathrm{ft})$ bgs. DIANA MOON was then conducted on August 27, 1968 at a depth of $242 \mathrm{~m}$ (794 ft) bgs. MILK SHAKE and DIANA MOON were both DoD tests and had accidental on-site releases.

The last two tests conducted in Frenchman Flat are MINUTE STEAK and DIAGONAL LINE. MINUTE STEAK was a DoD test and was detonated on September 12, 1969 at $265 \mathrm{~m}$ (869 ft) bgs. DIAGONAL LINE (DoD Test) was the last underground nuclear test conducted in Frenchman Flat. 
This test was detonated on November 24, 1971 at a depth of $264 \mathrm{~m}(866 \mathrm{ft})$ bgs. As a result of these two tests, accidental releases of radioactivity to the surface were detected. Radioactivity resulting from MINUTE STEAK was detected on site only. Radioactivity resulting from DIAGONAL LINE was detected off site by aircraft. No underground nuclear tests have been conducted in Frenchman Flat since 1971. Underground nuclear testing stopped in 1992 when the U.S. Congress imposed a ban on nuclear testing. The President has maintained this moratorium since then.

All tests were detonated in the alluvium except for PIN STRIPE which was detonated within the tuff unit of the Volcanic Aquifer. Five of the tests were detonated near or at the alluvium/Tertiary sediments contact. As a result, their cavities may span both the alluvium and volcanic units. All of these tests were conducted above but near the water table, except for CAMBRIC which was detonated $77 \mathrm{~m}(253 \mathrm{ft})$ below the water table.

Details about each of the underground nuclear tests conducted on Frenchman Flat are provided in the following section.

\subsection{Corrective Action Sites}

A total of 10 underground nuclear tests were conducted on the Frenchman Flat CAU. Five tests were detonated in Area 5 and five tests were detonated in Area 11 of the NTS. In the FFACO (1996), each of the 10 underground nuclear tests corresponds to a corrective action site. The locations of the CASs are shown in Figure 3-1.

Table 3-1 identifies each of the CASs along with their individual features. The table lists the CAS number, the emplacement hole name, the test name, the detonation date, the yield range, the depth of burial, the depth-to-water, working point geology, and land surface elevation.

Based on the data presented in Table 3-1, one test was conducted below the water table, and nine tests were conducted above the water table. Due to the proximity of the device detonations to the water table, e.g., beneath or within $100 \mathrm{~m}(328 \mathrm{ft})$, it is assumed that the groundwater at all the test locations has been contaminated. 


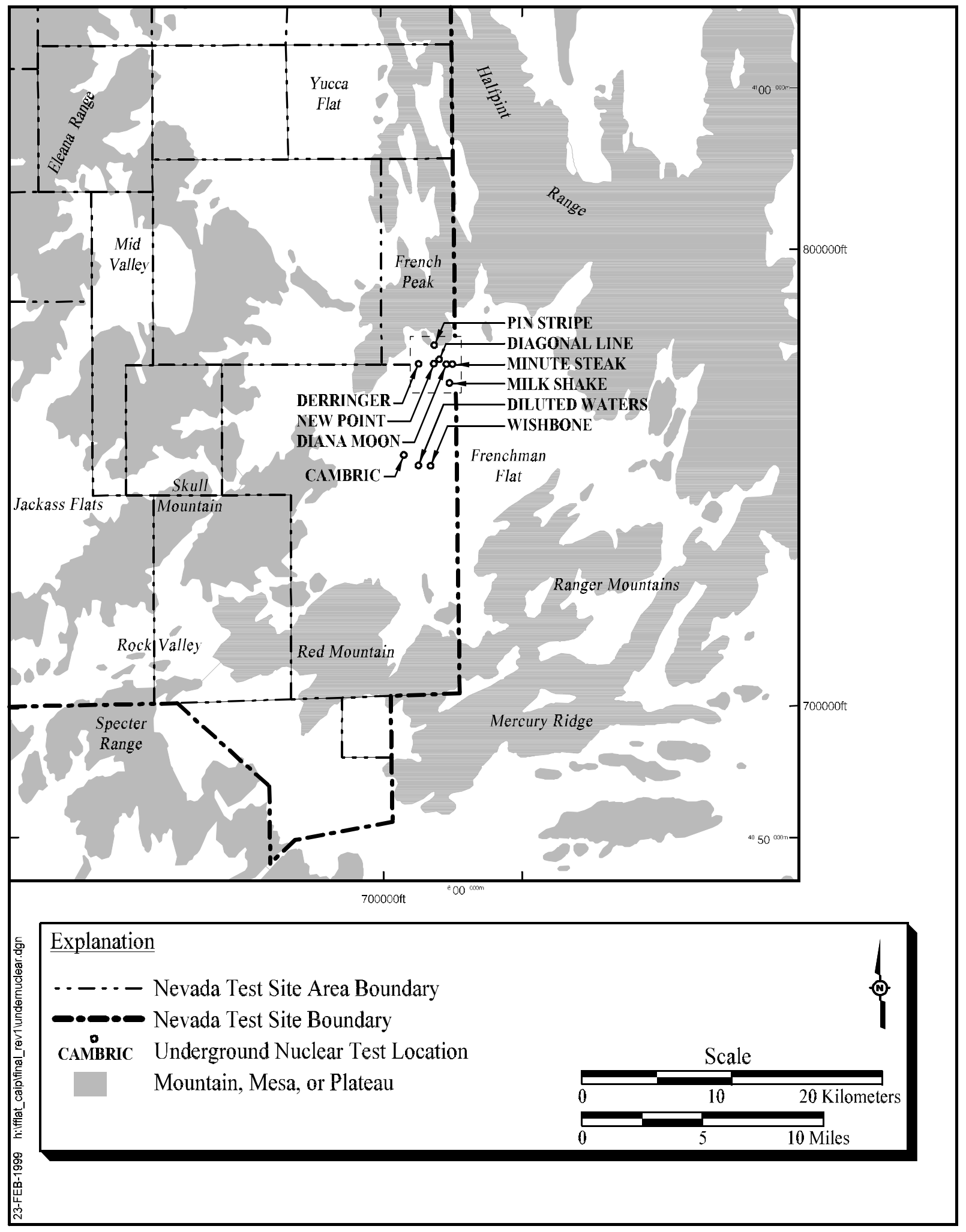

Figure 3-1

Location of Underground Nuclear Tests in Frenchman Flat 
Table 3-1

Corrective Action Sites in the Frenchman Flat Corrective Action Unit

\begin{tabular}{|c|c|c|c|c|c|c|c|c|c|c|c|c|}
\hline Test Name & $\begin{array}{c}\text { CAS } \\
\text { Number }\end{array}$ & Date & $\begin{array}{c}\text { Nevada State } \\
\text { Plane } \\
\text { Coordinates }\end{array}$ & $\begin{array}{c}\text { Yield } \\
\text { Range } \\
(\mathrm{kt})\end{array}$ & $\begin{array}{l}\text { Hole } \\
\text { Depth } \\
(\mathrm{m} / \mathrm{ft})\end{array}$ & $\begin{array}{c}\text { Working } \\
\text { Point } \\
\text { Depth } \\
(\mathrm{m} / \mathrm{ft})\end{array}$ & $\begin{array}{c}\text { Working } \\
\text { Point } \\
\text { Stratigraphy }\end{array}$ & $\begin{array}{c}\text { Working } \\
\text { Point } \\
\text { HSU }\end{array}$ & $\begin{array}{c}\text { Surface } \\
\text { Elevation } \\
(\mathrm{m} / \mathrm{ft})\end{array}$ & $\begin{array}{l}\text { Depth } \\
\text { to } \\
\text { Water } \\
\text { (m/ft) }\end{array}$ & $\begin{array}{c}\text { Water } \\
\text { Elevation } \\
(\mathrm{m} / \mathrm{ft} \text { amsl) }\end{array}$ & $\begin{array}{c}\text { Bottom of } \\
\text { Hole } \\
\text { Elevation } \\
\text { (m/ft amsl) }\end{array}$ \\
\hline CAMBRIC & 05-57-003 & $05 / 14 / 1965$ & $\begin{array}{l}N \text { 755,419 } \\
\text { E 704,831 }\end{array}$ & 0.75 & $\begin{array}{c}305 \\
1,000\end{array}$ & $\begin{array}{l}295 \\
968\end{array}$ & QTA & $A A$ & $\begin{array}{c}956 \\
3,137\end{array}$ & $\begin{array}{l}218 \\
715\end{array}$ & $\begin{array}{c}738 \\
2,421\end{array}$ & $\begin{array}{c}651 \\
2,135\end{array}$ \\
\hline DERRINGER & 05-57-004 & 09/12/1966 & $\begin{array}{l}N 775,216 \\
E 709,282\end{array}$ & 7.8 & $\begin{array}{c}648 \\
2,124\end{array}$ & $\begin{array}{l}255 \\
837\end{array}$ & QTA & AA & $\begin{array}{l}1,040 \\
3,412\end{array}$ & $\begin{array}{l}298 \\
977\end{array}$ & $\begin{array}{c}742 \\
2,434\end{array}$ & $\begin{array}{c}392 \\
1,286\end{array}$ \\
\hline $\begin{array}{c}\text { DIAGONAL } \\
\text { LINE }\end{array}$ & 11-57-005 & $11 / 24 / 1971$ & $\begin{array}{l}\text { N 775,819 } \\
\text { E 714,079 }\end{array}$ & $<20$ & $\begin{array}{l}277 \\
910\end{array}$ & $\begin{array}{l}264 \\
866\end{array}$ & QTA & $A A$ & $\begin{array}{l}1,038 \\
3,405\end{array}$ & $\begin{array}{l}301 \\
987\end{array}$ & $\begin{array}{c}737 \\
2,417\end{array}$ & $\begin{array}{c}761 \\
2,496\end{array}$ \\
\hline $\begin{array}{l}\text { DIANA } \\
\text { MOON }\end{array}$ & 11-57-003 & $08 / 27 / 1968$ & $\begin{array}{l}\text { N 775,094 } \\
\text { E 715,147 }\end{array}$ & $<20$ & $\begin{array}{l}255 \\
835\end{array}$ & $\begin{array}{l}242 \\
794\end{array}$ & QTA & $A A$ & $\begin{array}{l}1,032 \\
3,385\end{array}$ & $\begin{array}{l}295 \\
968\end{array}$ & $\begin{array}{c}737 \\
2,417\end{array}$ & $\begin{array}{c}777 \\
2,549\end{array}$ \\
\hline $\begin{array}{l}\text { DILUTED } \\
\text { WATERS }\end{array}$ & 05-57-002 & 06/16/1965 & $\begin{array}{l}N 753,500 \\
E 707,999\end{array}$ & $<20$ & $\begin{array}{l}206 \\
675\end{array}$ & $\begin{array}{l}193 \\
633\end{array}$ & QTA & $A A$ & $\begin{array}{c}943 \\
3,095\end{array}$ & $\begin{array}{l}208 \\
682\end{array}$ & $\begin{array}{c}735 \\
2,411\end{array}$ & $\begin{array}{c}737 \\
2,417\end{array}$ \\
\hline MILK SHAKE & 05-57-005 & 03/25/1968 & $\begin{array}{l}\text { N 773,094 } \\
\text { E 715,146 }\end{array}$ & $<20$ & $\begin{array}{l}276 \\
905\end{array}$ & $\begin{array}{l}265 \\
869\end{array}$ & QTA & $A A$ & $\begin{array}{l}1,021 \\
3,349\end{array}$ & $\begin{array}{l}282 \\
925\end{array}$ & $\begin{array}{c}739 \\
2,424\end{array}$ & $\begin{array}{c}745 \\
2,444\end{array}$ \\
\hline NEW POINT & 11-57-002 & $12 / 13 / 1966$ & $\begin{array}{l}\text { N 775,094 } \\
\text { E 713,147 }\end{array}$ & $<20$ & $\begin{array}{l}255 \\
836\end{array}$ & $\begin{array}{l}239 \\
784\end{array}$ & QTA & $A A$ & $\begin{array}{l}1,030 \\
3,378\end{array}$ & $\begin{array}{l}292 \\
958\end{array}$ & $\begin{array}{c}738 \\
2,421\end{array}$ & $\begin{array}{c}775 \\
2,542\end{array}$ \\
\hline $\begin{array}{l}\text { MINUTE } \\
\text { STEAK }\end{array}$ & 11-57-004 & 09/12/1969 & $\begin{array}{l}N 775,100 \\
E 715,900\end{array}$ & $<20$ & $\begin{array}{l}277 \\
910\end{array}$ & $\begin{array}{l}265 \\
869\end{array}$ & QTA & $A A$ & $\begin{array}{l}1,034 \\
3,393\end{array}$ & $\begin{array}{l}298 \\
977\end{array}$ & $\begin{array}{c}736 \\
2,414\end{array}$ & $\begin{array}{c}757 \\
2,483\end{array}$ \\
\hline WISHBONE & 05-57-001 & 02/18/1965 & $\begin{array}{l}\text { N 753,500 } \\
\text { E 709,999 }\end{array}$ & $<20$ & $\begin{array}{l}191 \\
626\end{array}$ & $\begin{array}{l}175 \\
574\end{array}$ & QTA & AA & $\begin{array}{c}941 \\
3,086\end{array}$ & $\begin{array}{l}206 \\
676\end{array}$ & $\begin{array}{c}735 \\
2,411\end{array}$ & $\begin{array}{c}750 \\
2,460\end{array}$ \\
\hline PIN STRIPE & $11-57-001$ & 04/25/1966 & $\begin{array}{l}\text { N 778,800 } \\
\text { E 712,275 }\end{array}$ & $<20$ & $\begin{array}{l}299 \\
980\end{array}$ & $\begin{array}{l}296 \\
971\end{array}$ & $\mathrm{TX}$ & VA & $\begin{array}{l}1,093 \\
3,586\end{array}$ & $\begin{array}{c}358 \\
1,174\end{array}$ & $\begin{array}{c}735 \\
2,411\end{array}$ & $\begin{array}{c}794 \\
2,604\end{array}$ \\
\hline
\end{tabular}

Sources: DOE/NV, 1994b; FFACO, 1996

$A A=$ Alluvial Aquifer

$\mathrm{VA}=$ Volcanic Aquifer

QTA = Quaternary Alluvium

$\mathrm{TX}=$ Volcanic units 


\subsection{Physical Setting}

An overview of the physical setting of the Frenchman Flat region is provided in this section. Descriptions of the physical features of interest to the Frenchman Flat CAI include climate, topography, geology, and groundwater hydrology. Other topics discussed are geochemistry, radiochemistry and the contaminant migration processes. Summaries of the available data are provided along with the descriptions. The data summaries were mostly obtained from the regional evaluation report (DOE/NV, 1997) and documentation packages (IT, 1996a through f; 1997a and b). In addition, information was also obtained from other reports cited throughout this section. During the CAI, the current understanding of the Frenchman Flat CAU conceptual model will be updated following a thorough data assessment process as discussed in Section 5.1.3.

\subsubsection{Climate}

The climate of Frenchman Flat is typical of southern Nevada and is characterized by limited precipitation, large diurnal changes in temperature, and winds that are dependent on seasonality and location.

Precipitation at Frenchman Flat is very light and dependent upon altitude. In the higher elevations surrounding the flat, annual precipitation is approximately 23 centimeters $(\mathrm{cm})(9$ inches [in.]) per year, which includes wintertime snow accumulations (French, 1986). The lower elevations that make up the major portion of the CAU receive approximately $15 \mathrm{~cm}$ (6 in.) of precipitation annually with occasional snow accumulations lasting only a few days (Quiring, 1968).

Temperature data for Frenchman Flat are available from a station located at Area 5 of the NTS. Daily maximum air temperatures range from 0 degrees Celsius $\left({ }^{\circ} \mathrm{C}\right)\left(32\right.$ degrees Fahrenheit $\left.\left[{ }^{\circ} \mathrm{F}\right]\right)$ in winter to $45^{\circ} \mathrm{C}\left(113{ }^{\circ} \mathrm{F}\right)$ in summer. Daily minimum air temperatures range from -15 degrees Celsius $\left({ }^{\circ} \mathrm{C}\right)$ $\left(5^{\circ} \mathrm{F}\right)$ in winter to $30^{\circ} \mathrm{C}\left(86^{\circ} \mathrm{F}\right)(\mathrm{BN}, 1999)$.

The movements of large-scale pressure systems control the seasonal changes in the wind direction frequencies. Predominating winds are southerly during summer and northerly during winter. The general downward slope in the terrain from north to south results in an intermediate scenario that is reflected in the characteristic diurnal wind reversal from southerly winds during the day to northerly winds at night. This north to south reversal is strongest in the summer and on occasion, becomes 
intense enough to override the wind regime associated with large-scale pressure systems (French, 1983 and DOE/NV, 1995). In Area 6, located in Yucca Flat, the average annual wind speed is 11 kilometers $(\mathrm{km})$ per hour (7 mi per hour) $(\mathrm{DOE} / \mathrm{NV}, 1995)$.

\subsubsection{Topography}

Frenchman Flat is a closed-drainage intermontane basin that is typical of the basin and range physiographic province. The relatively flat basin is surrounded by upland hills with major topographic features being Massachusetts Mountain to the northwest, Mount Salyer to the west, and the Ranger Mountains to the southeast. The flat portion of the basin slopes gently from the surrounding hills to the playa. In the immediate vicinity of the underground test locations, the basin slopes gently to the south-southeast with a surface elevation of approximately $1,040 \mathrm{~m}(3,412 \mathrm{ft}) \mathrm{amsl}$ at the location of the DERRINGER test in the northern section of the basin to a surface elevation of $941 \mathrm{~m}(3,086 \mathrm{ft})$ amsl at the location of the WISHBONE test to the south. The distance between these two points is approximately $6 \mathrm{~km}(3.7 \mathrm{mi})$ and produces a slope of $16.5 \mathrm{~m}$ per kilometer or 1.65 percent. The low point of the basin is Frenchman Playa, which has an elevation of approximately $938 \mathrm{~m}(3,078 \mathrm{ft})$ amsl.

\subsubsection{Surface Water}

There are no perennial surface water bodies located within the Frenchman Flat investigation area. In addition, no natural springs have been found in the CAU. Typically, surface water in the region only occurs during and after rain storm events, or as snow. This component of precipitation could be hydrologically significant and may potentially provide some recharge to the regional groundwater flow system via direct infiltration, or by being conducted from higher areas down washes or canyons to be redistributed to the alluvium. On occasion this water has reached the playa, which is the low point within Frenchman Flat, and for very brief periods could collect as a shallow surface water body.

\subsubsection{Geology}

An overview of the geology of the NTS region is presented, followed by a detailed description of the geology of the Frenchman Flat area. 


\subsubsection{Overview}

The geology of the NTS and the surrounding area is the product of a complex history, marked by major structural events (ERDA, 1977). The historical events that shaped the stratigraphy and structure of the region during the Precambrian, Paleozoic, Mesozoic, and Tertiary geologic times are described in this section. For a view of the surficial geology of the area, the reader is referred to the State of Nevada Geologic Map (Stewart and Carlson, 1978).

\section{Precambrian and Paleozoic}

The lowermost and oldest rocks in the NTS region are Precambrian in age. This region of the western United States was a stable, continental margin from Late Precambrian time until Late Devonian time (Middle Paleozoic). During the period of Late Precambrian to Early Cambrian, a thick section of sandstone and minor shales was deposited over the whole area of the NTS and beyond its boundaries. A thick section of predominately carbonate sediments from Late Cambrian to Late Devonian time was deposited on top of those clastic rocks (Dettinger et al., 1995). During the Mississippian Period, uplift north and west of the area resulted in erosion of highlands and deposition of thick sandstones interfingering with marine shelf shales in a foreland basin. During the Pennsylvanian Period, the basin was filled, and shallow marine carbonates were deposited over the Mississippian clastics. More than 10,600 $\mathrm{m}(34,700 \mathrm{ft})$ of Paleozoic and Late Precambrian sediments were deposited in the vicinity of the NTS. Table 3-2 shows the stratigraphic nomenclature of the marine sedimentary rocks in the region.

\section{Mesozoic}

During the Mesozoic Era, regional crustal shortening from the Sevier orogeny (mountain-forming process) produced large-scale, complex contractional features such as thrust fault systems, folds, and wrench faults. The entire region was affected by the contraction with regional detachments and generally north-south-trending predominant thrust systems (Armstrong, 1968). Locally, the stratigraphic sections are repeated vertically as a result of thrusting. The Sevier orogeny may have continued into Late Mesozoic time and included intrusion of granitic plutons. 
Table 3-2

Pre-Tertiary Stratigraphy and Hydrostratigraphy of the Nevada Test Site Region

\begin{tabular}{|c|c|c|c|c|c|}
\hline \multirow[t]{2}{*}{ Map Unit } & \multirow{2}{*}{$\begin{array}{l}\text { Stratigraphic } \\
\text { Symbol }\end{array}$} & \multicolumn{2}{|c|}{$\begin{array}{l}\text { Stratigraphic } \\
\text { Thickness }\end{array}$} & \multirow[t]{2}{*}{ Dominant Lithology } & \multirow{2}{*}{$\begin{array}{c}\text { Hydrostratigraphic } \\
\text { Unit }\end{array}$} \\
\hline & & $\mathrm{ft}$ & $\mathrm{m}$ & & \\
\hline $\begin{array}{l}\text { Chainman Shale } \\
\text { (CP Basin only) }\end{array}$ & Mc & 4,000 & 1,220 & $\begin{array}{l}\text { Argillite/ } \\
\text { Quartzite }\end{array}$ & $\begin{array}{l}\text { Upper Clastic } \\
\text { Confining Unit } \\
\text { (UCCU) }\end{array}$ \\
\hline $\begin{array}{l}\text { Guilmette Formation } \\
\text { Simonson Dolomite } \\
\text { Sevy Dolomite } \\
\text { Laketown Dolomite }\end{array}$ & $\begin{array}{l}\text { Dg } \\
\text { Ds } \\
\text { Dss } \\
\text { SI }\end{array}$ & $\begin{array}{c}1,400 \\
1,100 \\
690 \\
650\end{array}$ & $\begin{array}{l}430 \\
330 \\
210 \\
200\end{array}$ & $\begin{array}{l}\text { Limestone } \\
\text { Dolomite } \\
\text { Dolomite } \\
\text { Dolomite }\end{array}$ & \multirow{4}{*}{$\begin{array}{c}\text { Lower } \\
\text { Carbonate Aquifer } \\
\text { (LCA) }\end{array}$} \\
\hline $\begin{array}{l}\text { Ely Spring Dolomite } \\
\text { Eureka Quartzite }\end{array}$ & $\begin{array}{l}\text { Oes } \\
\text { Oe }\end{array}$ & $\begin{array}{l}340 \\
400\end{array}$ & $\begin{array}{l}105 \\
125\end{array}$ & $\begin{array}{l}\text { Dolomite } \\
\text { Quartzite }\end{array}$ & \\
\hline $\begin{array}{c}\text { Pogonip Group } \\
\text { Antelope Valley Limestone } \\
\text { Ninemile Formation } \\
\text { Goodwin Limestone }\end{array}$ & $\begin{array}{l}\mathrm{Oa} \\
\text { On } \\
\text { Og }\end{array}$ & $\begin{array}{l}1,530 \\
335 \\
685\end{array}$ & $\begin{array}{l}466 \\
102 \\
209\end{array}$ & $\begin{array}{l}\text { Limestone } \\
\text { Limestone } \\
\text { Limestone }\end{array}$ & \\
\hline $\begin{array}{c}\text { Nopah Formation } \\
\text { Bonanza King Formation } \\
\text { Carrara Formation }\end{array}$ & $\begin{array}{l}\mathrm{n} \\
\mathrm{b} \\
\mathrm{c}\end{array}$ & $\begin{array}{l}2,050 \\
4,350 \\
1,850\end{array}$ & $\begin{array}{c}620 \\
1,330 \\
570\end{array}$ & $\begin{array}{c}\text { Limestone } \\
\text { Limestone/Dolomite } \\
\text { Limestone/Shale/Siltstone }\end{array}$ & \\
\hline $\begin{array}{c}\text { Zabriskie Quartzite } \\
\text { Wood Canyon Formation }\end{array}$ & $\begin{array}{c}\mathrm{Z} \\
\mathrm{Zw}\end{array}$ & $\begin{array}{r}200 \\
2,300\end{array}$ & $\begin{array}{r}60 \\
700\end{array}$ & $\begin{array}{c}\text { Quartzite } \\
\text { Micaceous Quartzite }\end{array}$ & \multirow{2}{*}{$\begin{array}{c}\text { Lower } \\
\text { Clastic Confining } \\
\text { Unit }\end{array}$} \\
\hline $\begin{array}{l}\text { Stirling Quartzite } \\
\text { Johnnie Formation }\end{array}$ & $\begin{array}{l}\mathrm{Zs} \\
\mathrm{Zj}\end{array}$ & $\begin{array}{l}2,900 \\
3,000\end{array}$ & $\begin{array}{l}890 \\
914\end{array}$ & $\begin{array}{c}\text { Quartzite } \\
\text { Quartzite/Silt/Limestone }\end{array}$ & \\
\hline
\end{tabular}

Source: Modified from IT, 1996d

\section{Tertiary and Quaternary}

Following the Sevier orogeny, the highlands were severely eroded and late Precambrian clastic rocks were exposed at the surface locally. Following erosion throughout most of the early Tertiary Period, the area in and around the NTS began to be pulled apart with resultant normal and strike-slip faults associated with the formative stages of the modern Basin and Range structural province (Guth, 1981; Wernicke et al., 1988; Cole et al., 1989). Eruptions of the Southwestern Nevada Volcanic Field occurred in the Middle Tertiary Period (Sawyer et al., 1990; Warren et al., 1989), which coincided with this extension period. Successive eruptions produced no less than seven large and partially overlapping calderas that were filled with lava flows and blanketed surrounding Paleozoic and Precambrian rocks with vast deposits of tuff. Volcanic rocks now cover parts of the NTS region. 
These volcanic units are shown in Table 3-3 and are listed in relative depositional order with the oldest at the bottom right of the table and the youngest at the top left (Ferguson et al., 1994).

\subsubsection{Site Geology}

The geology of the Frenchman Flat area is very complex. As discussed in Section 3.4.4.1, over geologic time, several periods of deposition, uplift, and erosion in addition to numerous major deformational events, including volcanic activity, have resulted in a highly folded and faulted geologic structure and varied stratigraphic column. Most of the Frenchman Flat area is covered with recent alluvial material making the interpretation of previous geologic events very difficult.

The stratigraphic column for the Frenchman Flat area consists of (from oldest to youngest) Proterozoic and Lower Paleozoic clastic rocks, Paleozoic carbonate rocks, Tertiary sedimentary and tuffaceous sedimentary rocks, Tertiary volcanic rocks, and Quaternary and Tertiary alluvium (Hinrichs and McKay, 1965; Poole, 1965; Poole et al., 1965; Hinrichs, 1968; McKeown et al., 1976; Barnes et al., 1982). During the Tertiary Period, volcanic centers to the north and west of Frenchman Flat deposited volcanic materials over the exposed Paleozoic rock units close to these centers (Hinrichs and McKay, 1965). In areas of Frenchman Flat further away from these centers (to the south and east), these volcanic units become less significant and finally pinch out and are replaced in the stratigraphic column by sedimentary and tuffaceous sedimentary rock units (Poole, 1965; Poole et al., 1965; Hinrichs, 1968; Barnes et al., 1982). Most of the older sedimentary and volcanic rocks in the Frenchman Flat area are covered with recent (Upper Miocene and Holocene) alluvium (Hinrichs and McKay, 1965; Poole, 1965; Poole et al., 1965; Hinrichs, 1968; McKeown et al., 1976; Barnes et al., 1982; Wahl et al., 1997). The alluvium thickness ranges from a thin covering along the valley edges to perhaps as much as $900 \mathrm{~m}$ (3,000 ft) in the north central portion of Frenchman Flat.

Due to the extensive deformation, the structural geology of the Frenchman Flat area is very complicated. Two major periods of deformation have been identified in this area. The first major period of deformation (Sevier orogeny) took place during Late Mesozoic time when the region underwent compressional deformation that resulted in the folding, thrusting, uplift, and erosion of the Pre-Tertiary rocks (Barnes et al., 1982). The second period of deformation began approximately 16 million years ago and continued until at least 9.4 million years ago when the area underwent extensional deformation. This extension resulted in the formation of the present day Basin and Range 
Table 3-3

Quaternary and Tertiary Stratigraphy and Hydrostratigraphy of the Nevada Test Site Region

\begin{tabular}{|c|c|c|c|c|c|}
\hline $\begin{array}{c}\text { Stratigraphic } \\
\text { Unit }\end{array}$ & $\begin{array}{c}\text { Stratigraphic } \\
\text { Symbol }\end{array}$ & $\begin{array}{c}\text { Hydrostratigraphic } \\
\text { Nomenclature }\end{array}$ & $\begin{array}{c}\text { Stratigraphic } \\
\text { Unit }\end{array}$ & $\begin{array}{c}\text { Stratigraphic } \\
\text { Symbol }\end{array}$ & $\begin{array}{c}\text { Hydrostratigraphic } \\
\text { Nomenclature }\end{array}$ \\
\hline Alluvium & Qp, Qta, QTc & Alluvial Aquifer & Prow Pass Tuff & Tcp & \multirow{18}{*}{$\begin{array}{c}\text { Volcanic } \\
\text { Confining Unit }\end{array}$} \\
\hline $\begin{array}{l}\text { Volcanics of } \\
\text { Fortymile Canyon }\end{array}$ & Tf & \multirow{14}{*}{ Volcanic Aquifer } & Bullfrog Tuff & $\mathrm{Tcb}$ & \\
\hline $\begin{array}{l}\text { Timber Mountain } \\
\text { Group }\end{array}$ & $\mathrm{Tm}$ & & Tram Tuff & Tct & \\
\hline $\begin{array}{l}\text { Ammonia } \\
\text { Tanks Tuff }\end{array}$ & Tma & & \begin{tabular}{|l} 
Belted \\
Range Group
\end{tabular} & $\mathrm{Tb}$ & \\
\hline $\begin{array}{l}\text { Rainier Mesa } \\
\text { Tuff }\end{array}$ & Tmr & & $\begin{array}{l}\text { Dead Horse } \\
\text { Flat Formation }\end{array}$ & Tbd & \\
\hline $\begin{array}{l}\text { Tuff of } \\
\text { Holmes Road }\end{array}$ & Tmrh & & $\begin{array}{l}\text { Grouse Canyon } \\
\text { Tuff }\end{array}$ & Tbg & \\
\hline $\begin{array}{l}\text { Rhyolite of } \\
\text { Scrugham Peak }\end{array}$ & Tps & & $\begin{array}{l}\text { Team } \\
\text { Ridge Group }\end{array}$ & $\operatorname{Tr}$ & \\
\hline $\begin{array}{l}\text { Paintbrush } \\
\text { Group }\end{array}$ & $\mathrm{Tp}$ & & Tunnel Formation & $\mathrm{Tn}$ & \\
\hline $\begin{array}{l}\text { Tiva Canyon } \\
\text { Tuff }\end{array}$ & Tpc & & $\begin{array}{l}\text { Volcanics of } \\
\text { Quartz Mountain }\end{array}$ & $\mathrm{Tq}$ & \\
\hline $\begin{array}{l}\text { Topopah Spring } \\
\text { Tuff }\end{array}$ & Tpt & & $\begin{array}{l}\text { Volcanics of } \\
\text { Big Dome }\end{array}$ & Tu & \\
\hline $\begin{array}{l}\text { Volcanics } \\
\text { of Area } 20\end{array}$ & $\mathrm{Ta}$ & & $\begin{array}{l}\text { Tub } \\
\text { Spring Tuff }\end{array}$ & Tub & \\
\hline $\begin{array}{l}\text { Calico Hills } \\
\text { Formation }\end{array}$ & Tac & & Older Volcanics & To & \\
\hline $\begin{array}{l}\text { Volcanics of } \\
\text { Area } 20\end{array}$ & $\mathrm{Ta}$ & & $\begin{array}{c}\text { Tunnel } \\
\text { Bed } 2\end{array}$ & Ton2 & \\
\hline $\begin{array}{l}\text { Wahmonie } \\
\text { Formation }\end{array}$ & Tw & & $\begin{array}{l}\text { Yucca } \\
\text { Flat Tuff }\end{array}$ & Toy & \\
\hline $\begin{array}{l}\text { Tuff of Mara } \\
\text { Wash }\end{array}$ & Tww & & $\begin{array}{l}\text { Tunnel } \\
\text { Bed } 1\end{array}$ & Ton1 & \\
\hline \multirow{3}{*}{$\begin{array}{l}\text { Crater Flat } \\
\text { Group }\end{array}$} & \multirow{3}{*}{ Tc } & \multirow{3}{*}{$\begin{array}{c}\text { Volcanic } \\
\text { Confining Unit }\end{array}$} & $\begin{array}{l}\text { Redrock } \\
\text { Valley Tuff }\end{array}$ & Tor & \\
\hline & & & $\begin{array}{l}\text { Fraction } \\
\text { Tuff }\end{array}$ & Tof & \\
\hline & & & Paleocolluvium & $\mathrm{TI}$ & \\
\hline
\end{tabular}


topography and the Frenchman Flat basin (Ekren et al., 1968). Beneath Frenchman Flat, major west-dipping normal faults merge and are probably contemporaneous with strike-slip faults beneath the southern portion of the basin. Beneath the central portion of Frenchman Flat, movement along the north-striking normal faults has created a series of relatively narrow, east-dipping, half-graben, subbasins elongated in a northern direction (Grauch and Hudson, 1995).

During the development of the regional geologic model (IT, 1996d), detailed geologic cross sections were developed for the region. Portions of five of these sections pass through different parts of Frenchman Flat and are designated CR-4, CR-5, KR-1, KR-2, and MS-2. The locations of these sections are shown in Figure 3-2. As shown in the figure, three of the sections (KR-1, KR-2 and MS-2) are oriented in a northwest-southeast direction and CR-4 and CR-5 are in an east-west orientation. Three of the cross sections (CR-4, KR-1, and MS-2) are shown in Figure 3-3, Figure 3-4, and Figure 3-5, respectively. Each of these sections show the complexity of the geology in the Frenchman Flat area and the characteristic half graben structures formed during the major deformation events (Drellack, 1995a).

\subsubsection{Hydrogeology}

A brief description of the hydrogeology of the region is provided, followed by a description of the hydrogeology of the investigation area.

\subsubsection{Regional Hydrogeology}

The regional hydrogeology of the NTS is described in detail in the regional model report (DOE/NV, 1997). A summary, including descriptions of the hydrostratigraphy and groundwater of the region, is provided here.

\subsection{Hydrostratigraphy}

Groundwater flowing beneath the NTS region passes through diverse rocks that differ substantially in terms of age, composition, and water-bearing properties. These rocks form a complex three-dimensional framework of groundwater conduits and barriers that can be described as hydrogeologic or hydrostratigraphic units (HSU). The HSUs may be aquifers or confining units on the basis of their ability to store and transmit water. 


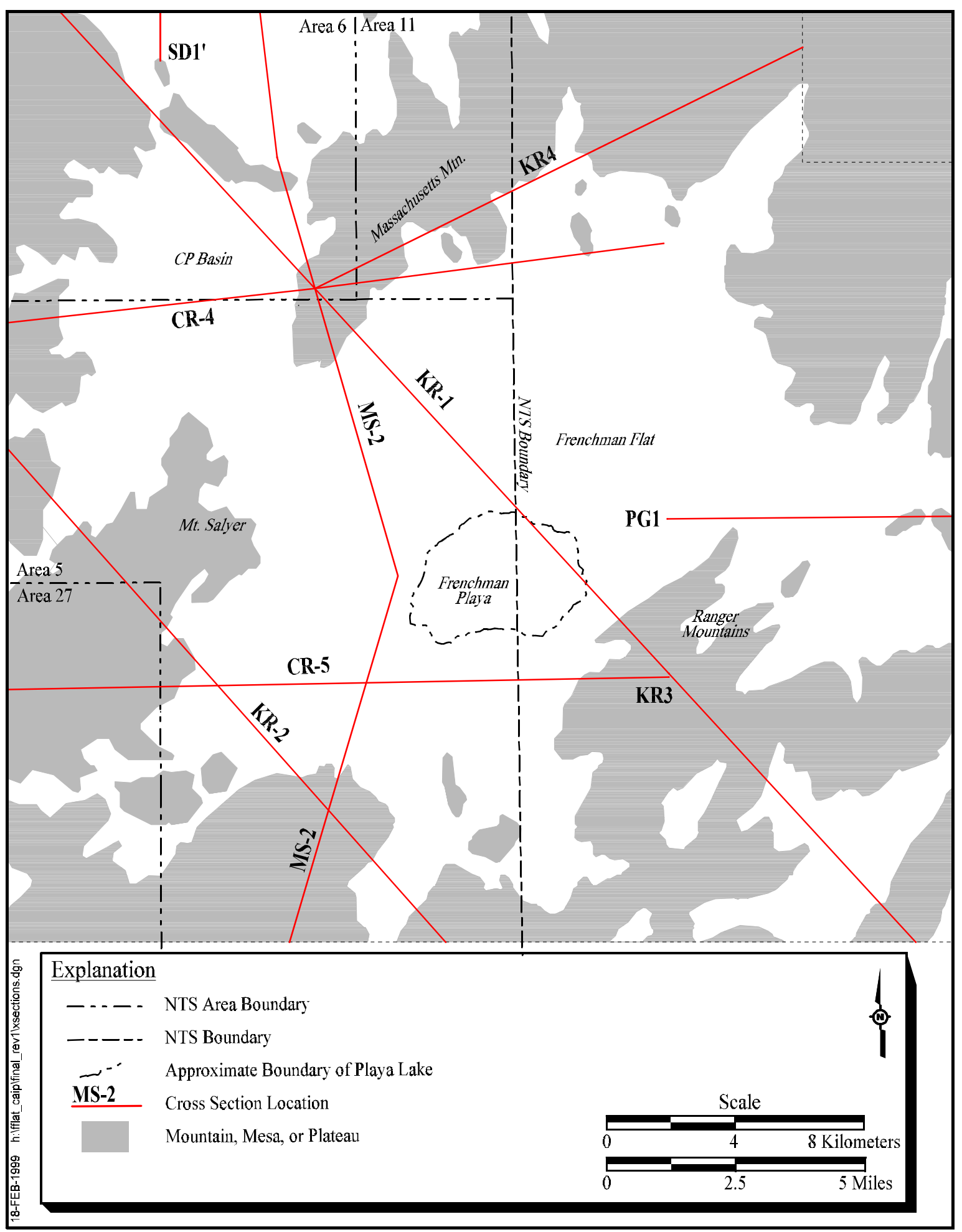

Figure 3-2 Frenchman Flat Corrective Action Unit Cross-Section Location Map 


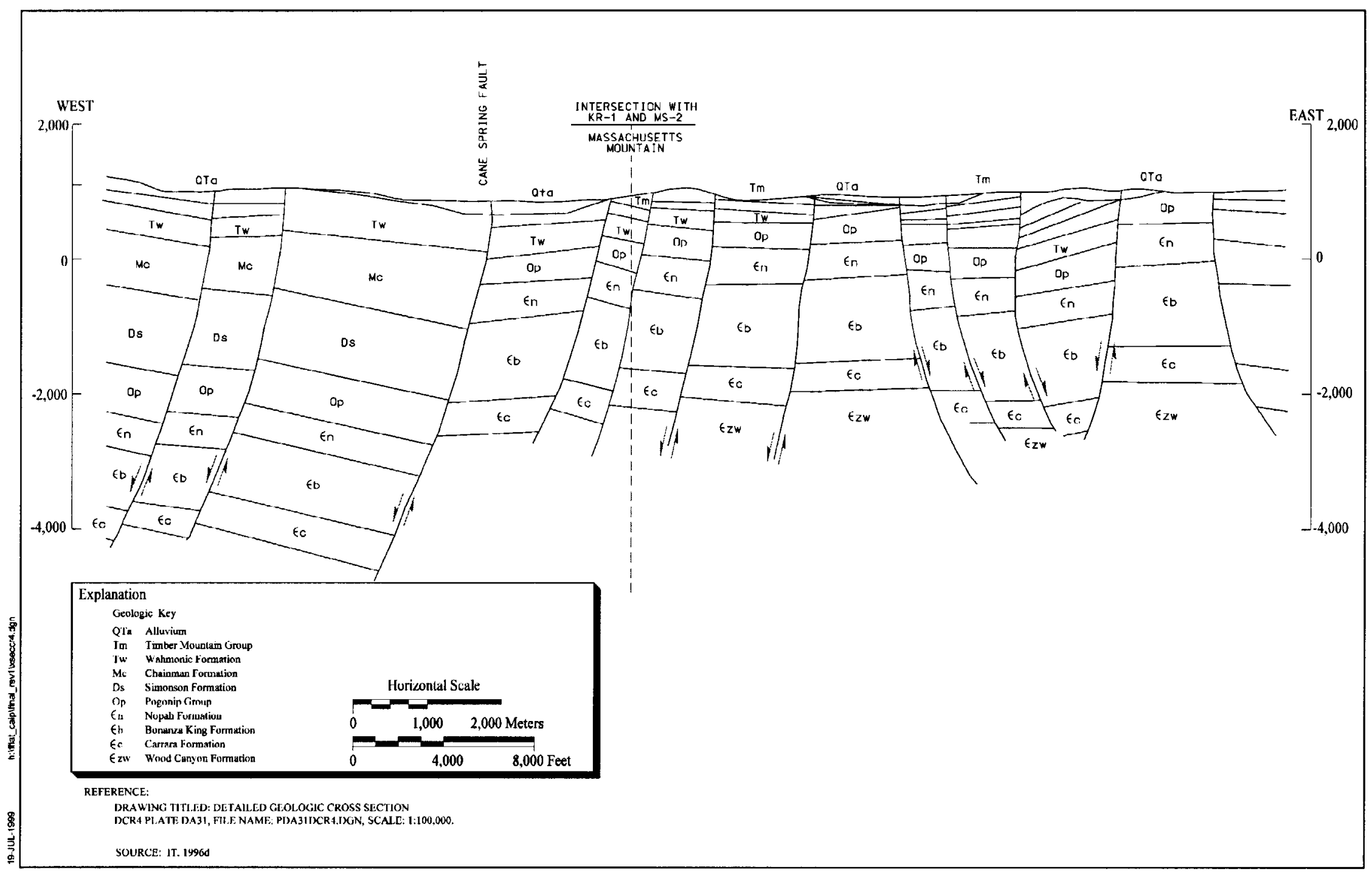

Figure 3-3

Geologic Cross Section CR-4 


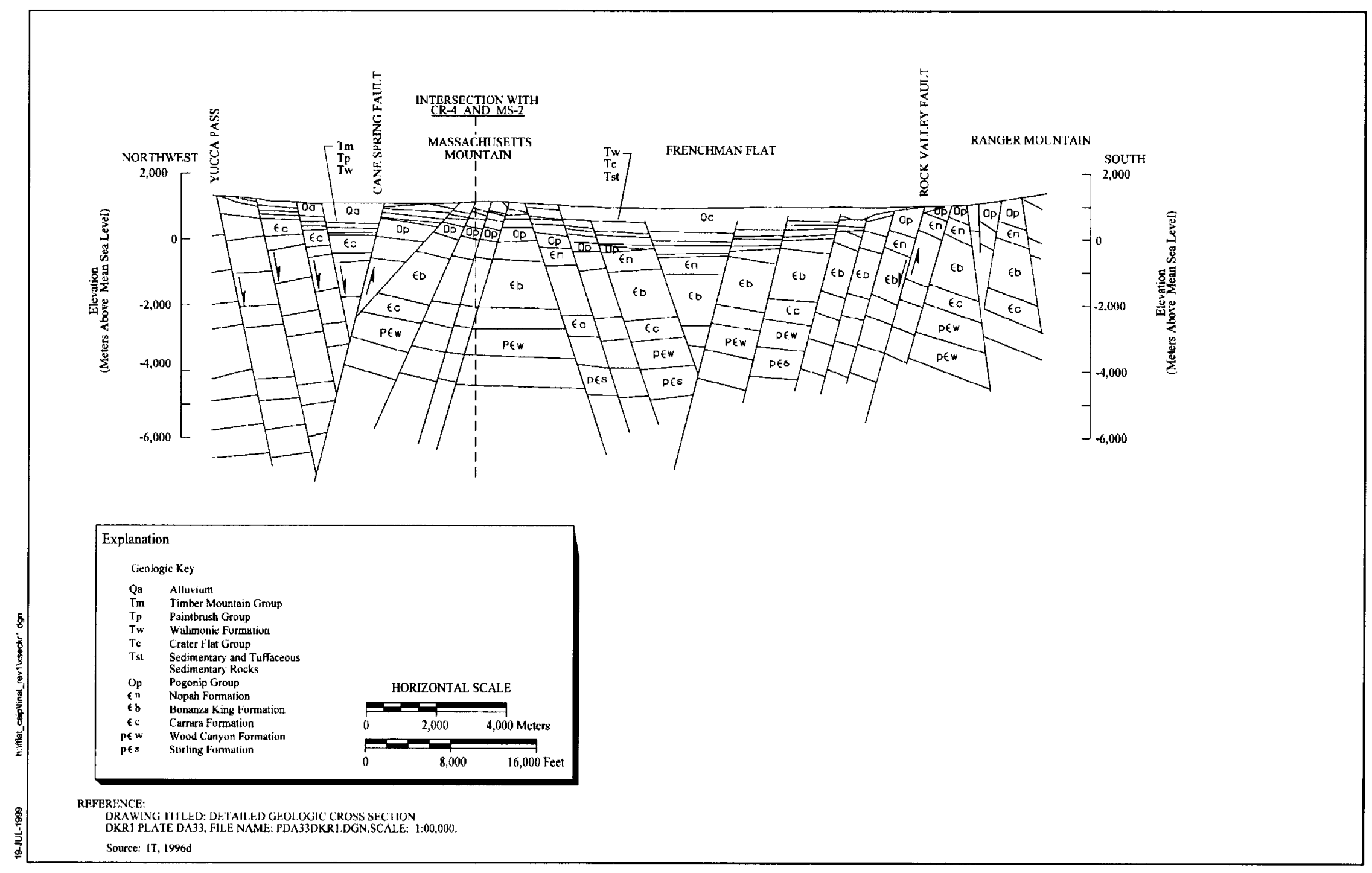

Figure 3-4

Geologic Cross Section KR-1 


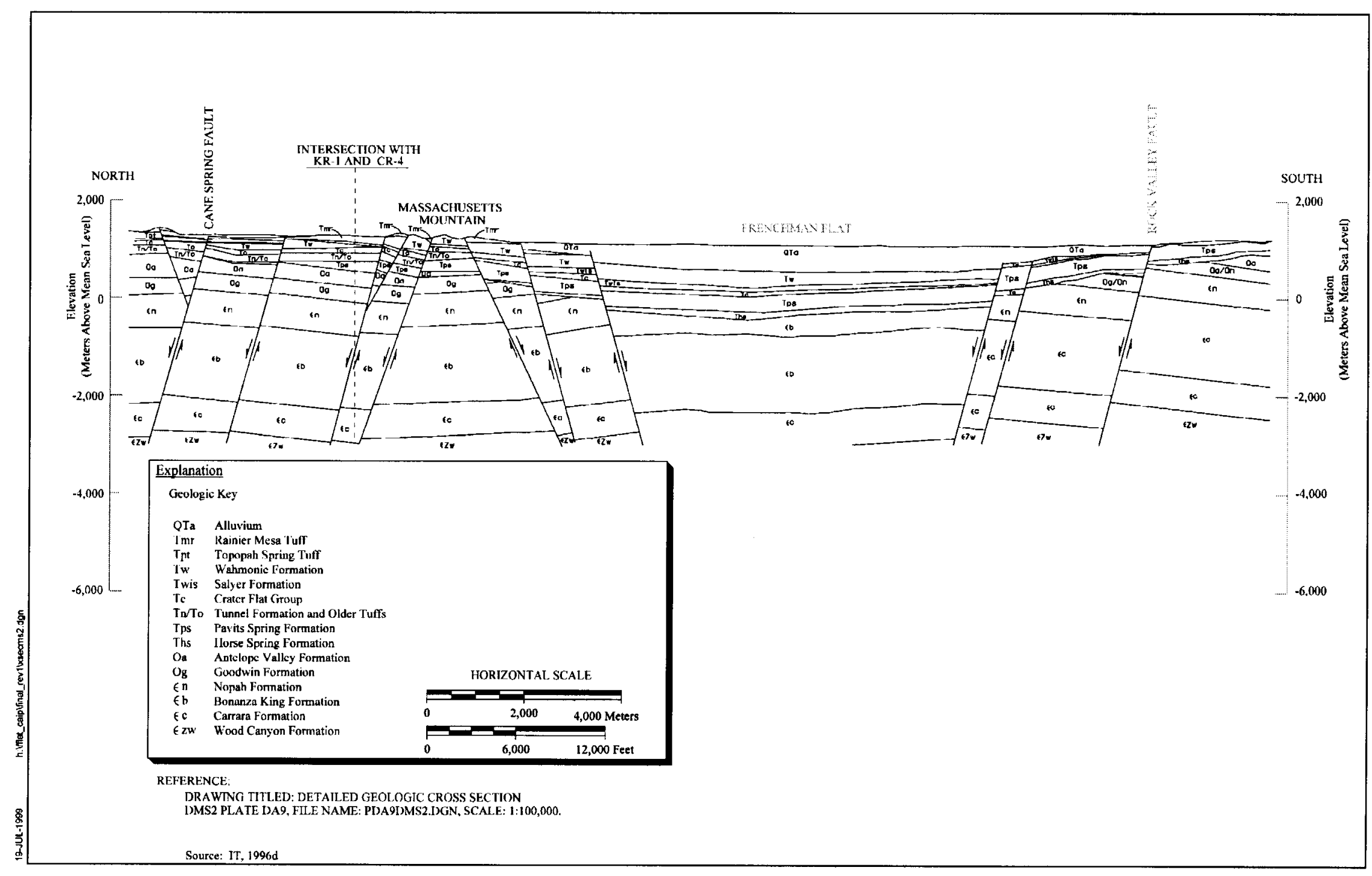

Figure 3-5

Geologic Cross Section MS-2 
During the regional evaluation (DOE/NV, 1997), the framework of the NTS regional groundwater flow system was subdivided into 26 HSUs as depicted in Table 3-4. Some of the HSUs were grouped into geologic model layers. A total of 20 geologic model layers were defined (Table 3-4). Thirty-six structural blocks and six HSUs were defined to represent the Timber Mountain/Silent Canyon Caldera Complex. Outside of the caldera complex, the volcanic units have been given different designations. The details of the methodology used to group the stratigraphic units into HSUs are available in the Regional Geologic Model Documentation Package (IT, 1996d).

The Lower Carbonate Aquifer and Lower Clastic Confining Unit are the most expansive HSUs within the area. The Lower Carbonate Aquifer is the most important aquifer due to its wide distribution and high hydraulic conductivity. The Lower Clastic Confining Unit generally underlies the other HSUs and has extremely low hydraulic conductivities (virtually impermeable). It was assumed to be the basement of the groundwater flow system. The Lower Carbonate Aquifer and Lower Clastic Confining Unit predominantly control regional groundwater flow. The distribution and thickness of the Lower Carbonate Aquifer is spatially variable and controlled by the structural position of the underlying Lower Clastic Confining Unit. In general, the Lower Carbonate Aquifer is thin or missing on structural highs and is thickest in structural lows.

The available hydraulic conductivity data were compiled and reduced to provide estimated values for the major HSUs defined in the regional model (DOE/NV, 1997). The available data were obtained from hydraulic tests conducted in selected wells of the NTS region (IT, 1996b). Results of the hydraulic testing only provide estimates of the local properties of these HSUs. These results have been extrapolated to incorporate the entire NTS regional groundwater flow system. Hydraulic conductivity ranges for the main aquifers are presented in Table 3-5. The hydraulic conductivity of the Alluvial Aquifer is smaller than that of carbonate aquifers, but higher than that of the volcanic aquifers. The range of conductivity for each aquifer shown in Table 3-5 extends over orders of magnitude. For example, within the Lower Carbonate Aquifer, the range of hydraulic conductivity is estimated to be between 0.0008 and 1,570 meters per day $(\mathrm{m} / \mathrm{d})(0.003$ and 5,150 feet per day [ft/d]), representing interstitial and fracture porosity. This large range suggests that over the NTS region, large variability in hydraulic conductivity can be expected. Similar ranges of values for different rock types have been reported in Freeze and Cherry (1979), indicating that the data for the NTS region are 
Table 3-4

Hydrostratigraphic Units/Geologic Model Layers of the Nevada Test Site Region

\begin{tabular}{|c|c|c|}
\hline Model Layer Name & $\begin{array}{l}\text { HSU } \\
\text { Name }\end{array}$ & Description \\
\hline Alluvial Aquifer (AA) & AA & Alluvial Aquifer \\
\hline Timber Mountain Aquifer (TMA) & TMAQ-7 & Uppermost Welded Tuffs \\
\hline \multirow{2}{*}{ Tuff Cones (TC) } & TPTC-6 & Laterally Variable Tuffs and Lava Flows of Paintbrush Group Tuff Cone \\
\hline & TPTC-5 & Laterally Variable Tuffs and Lava Flows of Calico Hills \\
\hline Bullfrog Confining Unit (TCB) & TCBCU-4 & Non-welded Tuffs \\
\hline Belted Range Aquifer (TBA) & TBAQ-3 & Welded Tuffs above BCU-2 \\
\hline Basal Confining Unit (BCU) & BCU-2 & Non-welded Tuffs \\
\hline Basal Aquifer (BAQ) & $\mathrm{BAQ}-1$ & Welded Tuffs \\
\hline \multirow{5}{*}{ Volcanic Aquifer (VA) } & WTA & Welded-Tuff Aquifer \\
\hline & VTA & Vitric-Tuff Aquifer \\
\hline & TCU2 & Zeolitized-Tuff Confining Unit (Upper) Volcanic-Tuff Aquifer \\
\hline & TPTA & Topopah Springs Tuff Aquifer \\
\hline & WLA & Wahmonie Lava Aquifer \\
\hline \multirow{2}{*}{ Volcanic Confining Unit (VCU) } & TCU1 & Zeolitized-Tuff Confining Unit (Lower) \\
\hline & VCCU & Volcaniclastic Confining Unit (Volcanic-Tuff Confining Unit) \\
\hline Volcanics Undifferentiated (VU) & VU & Volcanics Undifferentiated \\
\hline \multirow{2}{*}{$\begin{array}{l}\text { Death Valley Section - Death } \\
\text { Valley Section (TSDVS) }\end{array}$} & TS & Tertiary Sediments \\
\hline & DVS & Death Valley Section \\
\hline $\begin{array}{l}\text { Lower Carbonate Aquifer-Yucca } \\
\text { Flat Upper Plate (LCA3) }\end{array}$ & LCA3 & $\begin{array}{c}\text { Lower Carbonate Aquifer (Yucca Flat Upper Plate), Upper Carbonate } \\
\text { Aquifer in NTS Area }\end{array}$ \\
\hline $\begin{array}{l}\text { Upper Clastic Confining Unit } \\
\text { (UCCU) }\end{array}$ & UCCU & Upper Clastic-Confining Unit \\
\hline Lower Carbonate Aquifer (LCA) & LCA & Lower Carbonate Aquifer \\
\hline $\begin{array}{l}\text { Lower Clastic Confining Unit } \\
\text { (LCCU) }\end{array}$ & LCCU & Lower Clastic-Confining Unit \\
\hline $\begin{array}{l}\text { Lower Carbonate Aquifer-Upper } \\
\text { Plate (LCA1) }\end{array}$ & LCA1 & Lower Carbonate Aquifer (Upper Plate) \\
\hline $\begin{array}{l}\text { Lower Clastic Confining } \\
\text { Unit-Upper Plate (LCCU1) }\end{array}$ & LCCU1 & Lower Clastic-Confining Unit (Upper Plate) \\
\hline $\begin{array}{l}\text { Lower Carbonate Aquifer-Lower } \\
\text { Plate (LCA2) }\end{array}$ & LCA2 & Lower Carbonate Aquifer (Lower Plate) \\
\hline $\begin{array}{l}\text { Lower Clastic Confining Unit - } \\
\text { Lower Plate (LCCU2) }\end{array}$ & LCCU2 & Lower Clastic-Confining Unit (Lower Plate) \\
\hline Intrusives (I) & 1 & Intrusives \\
\hline
\end{tabular}

Source: Modified from DOE/NV, 1997

$\mathrm{HSU}=$ Hydrostratigraphic Unit 
Table 3-5

Ranges of Hydraulic Conductivity for the Major Aquifers of the Nevada Test Site Region

\begin{tabular}{|c|c|c|}
\hline \multirow{2}{*}{ Aquifer } & \multicolumn{2}{|c|}{ Hydraulic Conductivity } \\
\cline { 2 - 3 } & $\begin{array}{c}\text { Mean } \\
(\mathrm{m} / \mathrm{d})\end{array}$ & $\begin{array}{c}\text { Range } \\
(\mathrm{m} / \mathrm{d})\end{array}$ \\
\hline \hline Alluvial Aquifer & 8.44 & $0.00006-83$ \\
\hline Volcanic Aquifers & 1.18 & $0.0003-12$ \\
\hline Carbonate Aquifers & 31.71 & $0.0008-1,570$ \\
\hline
\end{tabular}

Source: DOE/NV, 1997

$\mathrm{m} / \mathrm{d}=\operatorname{Meter}(\mathrm{s})$ per day

not unusual. The details regarding the hydraulic parameters estimated for HSUs are presented in the Hydraulic Parameter Data Documentation Package (IT, 1996b).

The available hydraulic conductivity data were also used to estimate the total depth of the flow system and evaluate the relationship between hydraulic conductivity and depth for the major aquifers (IT, 1996b). The analysis of data available for all rock types showed that a decreasing linear trend exists in the logarithm of hydraulic conductivity with increased depth; thus, hydraulic conductivity decreases exponentially with depth (IT, 1996b). The relationship is provided by the following equation:

$$
\mathrm{K}_{\text {depth }}=\mathrm{K}_{\mathrm{h}}\left(10^{-\lambda \mathrm{d}}\right)
$$

where:

$\mathrm{K}_{\text {depth }}=$ horizontal hydraulic conductivity at specified depth (m/d);

$\mathrm{K}_{\mathrm{h}}=$ horizontal hydraulic conductivity at land surface $(\mathrm{m} / \mathrm{d})$;

$\lambda=$ Hydraulic conductivity decay coefficient $(1 / \mathrm{m}) ;$ and

$\mathrm{d}=$ depth from land surface $(\mathrm{m})$. 
Using equation 3-1, it was found that a depth of 3,000 $\mathrm{m}(9,843 \mathrm{ft})$ likely represents the bottom of the flow system because at greater depths the extrapolated hydraulic conductivity values are less than $10^{-7} \mathrm{~m} / \mathrm{d}\left(3.3 \times 10^{-7} \mathrm{ft} / \mathrm{d}\right)$. Such low values are representative of virtually impermeable media.

The analysis of hydraulic conductivity for each of the major aquifers (Alluvial Aquifer, Volcanic Aquifer, and Lower Carbonate Aquifer) showed that within each of the aquifers, hydraulic conductivity also decreases exponentially with depth (IT, 1996b). However, as explained in the regional model document (DOE/NV, 1997), the rate of decrease varies from one aquifer type to the next. The rate of decrease of hydraulic conductivity with depth is determined by the value of $\lambda$, the conductivity decay coefficient. The $\lambda$ values for the three aquifers are provided in Table 3-6.

Table 3-6

Hydraulic Conductivity Decay Coefficients with Depth

\begin{tabular}{|c|c|c|c|c|c|c|}
\hline \multirow{2}{*}{ Aquifer } & \multicolumn{3}{|c|}{ Decay Coefficient (day-1) } & \multicolumn{3}{|c|}{$\begin{array}{l}\text { Hydraulic Conductivity } \\
\text { at Land Surface meters per day }(\mathrm{m} / \mathrm{d})\end{array}$} \\
\hline & $\begin{array}{l}\text { lower } 95 \% \\
\text { C.I. }\end{array}$ & mean & $\begin{array}{l}\text { upper } 95 \% \\
\text { C.I. }\end{array}$ & $\begin{array}{l}\text { lower } 95 \% \\
\text { C.I. }\end{array}$ & mean & $\begin{array}{l}\text { upper } 95 \% \\
\text { C.I. }\end{array}$ \\
\hline Alluvial & 0.00724 & 0.00563 & 0.00402 & 6.04 & 21.18 & 74.25 \\
\hline Carbonate & 0.00160 & 0.00102 & 0.00044 & 2.60 & 6.76 & 17.59 \\
\hline Volcanics & 0.00306 & 0.00256 & 0.00205 & 2.15 & 7.75 & 27.87 \\
\hline
\end{tabular}

C.I. = Confidence Interval

\subsection{Groundwater}

A conceptual model of the regional groundwater flow was developed during the regional evaluation (DOE/NV, 1997). Figure 3-6 depicts the characteristics of the regional groundwater flow system, including the groundwater flow system boundary, areas of recharge, and areas of evapotranspiration (ET). This section provides a summary description of the regional flow system.

Saturated alluvial materials are present in central and southern Yucca Flat, Frenchman Flat, and Jackass Flats on the NTS, and in other basins located throughout the flow system. Saturated Tertiary volcanics are present in the western section of the region. The distribution and thickness of alluvial and volcanic aquifers are highly variable throughout the region and are not interpreted to be 


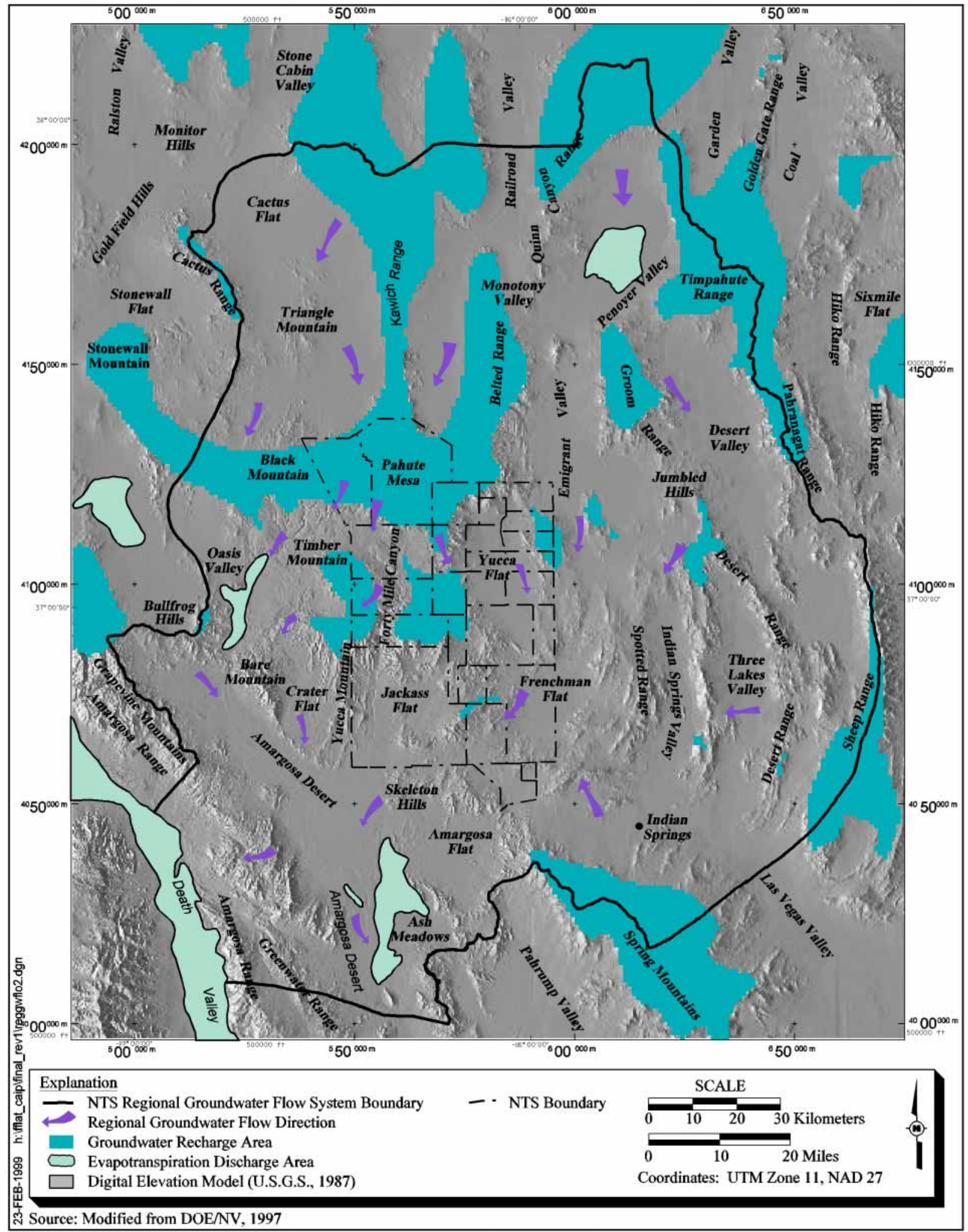

Figure 3-6

Features of the Nevada Test Site Regional Groundwater Flow System 
continuous. In most instances, an alluvial aquifer is confined to a basin by surrounding mountain ranges. In some basins, alluvial aquifers are discontinuous due to structural controls elevating the bottom of the alluvium above the water table. In general, alluvial and volcanic aquifers are considered depositional elements overlying the regional flow system and only influence regional flow in localized areas. The underlying Lower Carbonate Aquifer is the principal aquifer of the regional flow system. The Lower Carbonate Aquifer forms a nearly continuous aquifer across the region except where interrupted by calderas, truncated by structural controls, or penetrated by intrusive rocks (Prudic et al., 1993).

Depths to groundwater beneath the NTS and surrounding region vary greatly. Groundwater depths in the southern NTS range from about $10 \mathrm{~m}$ (33 ft) beneath upper Fortymile Wash to $157 \mathrm{~m}$ (515 ft) beneath Frenchman Lake (Winograd and Thordarson, 1975) compared to more than $610 \mathrm{~m}(2,000 \mathrm{ft})$ beneath Pahute Mesa in the northern NTS. Perched groundwater is found locally throughout the NTS. Perched groundwater occurs locally within the tuff confining units and, to some extent, overlying units. In the highlands, springs emerge from perched groundwater lenses. Spring discharge rates are low, and this water is used only by wildlife.

The general direction of groundwater flow in the regional flow system is from north to south and east to southwest (Figure 3-6). The direction of groundwater flow is locally influenced in areas where structural and geologic conditions have controlled the distribution and thickness of the Lower Carbonate Aquifer. In some areas of the regional flow system, groundwater encounters structural and geologic conditions, such as structural highs of the Lower Clastic Confining Unit, that promote an upward flow component. The upward flow component brings water to discharge at the surface in the form of a wet playa or springs. The discharge is then lost from the flow system through ET. Conversely, there is groundwater flow between basins in the form of subsurface inflow and outflow. Ultimately, however, the groundwater is lost by ET at other surface discharge areas located downgradient.

Hydraulic gradients are very low to the east and south of the NTS, suggesting the presence of very transmissive media (thick Lower Carbonate Aquifer). In other areas, the prevailing flow direction and hydraulic gradients may locally be influenced by the structural position of geologic units with significantly lower transmissivity than that of the Lower Carbonate Aquifer. If the low transmissive 
units are structurally oriented so that they are perpendicular to flow, flow might be significantly altered, causing steep hydraulic gradients. If their structural orientation is parallel to the prevailing flow direction, their effect may be insignificant. Structural uplifts of the Lower Clastic Confining Unit and the distribution of the Upper Clastic Confining Unit have caused several of the observed steep gradients within the flow system. Low permeability sediments along the Funeral Mountains, i.e., Tertiary Sediments of the Death Valley Section, have also caused a steep hydraulic gradient between Amargosa Desert and Death Valley.

Groundwater recharge occurs by precipitation at higher elevations (Figure 3-6) and infiltration along stream courses and in playas. Discharge occurs naturally as evapotranspiration, and potential underflow beneath the discharge areas to Death Valley. Artificial discharge occurs as groundwater pumpage from drinking-water supply wells (public and domestic), agricultural wells, and industrial wells. Public, domestic, and industrial water-supply wells for the NTS produce water from the carbonate, volcanic, and valley-fill aquifers. South of the NTS, private and public water-supply wells are completed in the valley-fill aquifer (DOE/NV, 1995). At the regional scale, the artificial groundwater discharge by well is not considered significant. An estimate of the regional steady-state groundwater budget is provided in Table 3-7.

Table 3-7

Estimate Steady-State Groundwater Budget for the Nevada Test Site Regional Groundwater Flow System

\begin{tabular}{|c|c|}
\hline $\begin{array}{l}\text { Recharge } \\
\text { Recharge from precipitation } \\
\text { Subsurface inflow } \\
\text { Total Natural Recharge }\end{array}$ & $\begin{array}{r}177,484-289,410 \mathrm{~m}^{3} / \mathrm{d} \\
5,405-70,100 \mathrm{~m}^{3} / \mathrm{d} \\
182,889-359,510 \mathrm{~m}^{3} / \mathrm{d}\end{array}$ \\
\hline $\begin{array}{l}\text { Discharge } \\
\text { Surface discharge (ET and springs) } \\
\text { Subsurface outflow } \\
\text { Total Natural Discharge }\end{array}$ & $\begin{array}{r}135,340-300,700 \mathrm{~m}^{3} / \mathrm{d} \\
850-\quad 5,100 \mathrm{~m}^{3} / \mathrm{d} \\
\mathbf{1 3 6 , 1 9 0 - 3 0 5 , 8 0 0} \mathrm{m}^{3} / \mathrm{d}\end{array}$ \\
\hline
\end{tabular}

Source: DOE/NV, 1997

$\mathrm{m}^{3} / \mathrm{d}=$ Cubic meter(s) per day 


\subsubsection{Hydrogeology of the Investigation Area}

The hydrogeology of the area of interest will be investigated during the CAI. The current understanding is based on existing data.

\subsection{Hydrostratigraphy}

The HSUs of the Frenchman Flat area were defined during the regional evaluation (DOE/NV, 1997). The Frenchman Flat hydrostratigraphy includes several aquifers and confining units. The aquifers are the Lower Carbonate Aquifer, the Volcanic Aquifer, and the Alluvial Aquifer. The available hydraulic conductivities for the aquifers of Frenchman Flat and vicinity are presented in Table 3-8.

Table 3-8

Hydraulic Conductivity Summary Statistics for the Volcanic Hydrostratigraphic Units of Pahute Mesa

(Variable is Log $[\mathrm{K}]$ with $\mathrm{K}$ in meters per day)

\begin{tabular}{|c|c|c|c|c|c|c||}
\hline Aquifer & Mean & $\begin{array}{c}\text { Standard } \\
\text { Deviation }\end{array}$ & Variance & Minimum & Maximum & Count \\
\hline \hline AA & -0.356 & 1.562 & 2.439 & -1.016 & 0.477 & 31 \\
\hline TMA & 0.088 & 0.212 & 0.045 & 0.017 & 0.140 & 4 \\
\hline LCA & 0.171 & 2.296 & 5.272 & -0.695 & 0.961 & 11 \\
\hline
\end{tabular}

Source: Modified from IT, 1996b

The statistics presented were derived from data gathered during the regional evaluation (IT, 1996b; DOE/NV, 1997). All HSUs present are described in the following subsections, according to their geologic age from oldest to youngest.

\subsection{Pre-Tertiary Age HSUs}

The hydrostratigraphy of the pre-Tertiary sedimentary rocks in the Frenchman Flat area (Table 3-2) follows the framework developed by Winograd and Thordarson (1975). Pre-Tertiary HSUs include the Lower Clastic Confining Unit, the Lower Carbonate Aquifer, and the Upper Clastic Confining Unit. 


\section{Lower Clastic Confining Unit}

The Proterozoic to Middle-Cambrian rocks are largely quartzite and silica-cemented siltstone. Although these rocks are brittle and often fractured, secondary mineralization seems to have greatly reduced formation permeability (Winograd and Thordardson, 1975). These units make up the Lower Clastic Confining Unit, which is considered to be the basement of the regional groundwater system (IT, 1996d and IT, 1997a). Where it is in a structurally high position, the Lower Clastic Confining Unit may act as a barrier to regional groundwater flow.

\section{Lower Carbonate Aquifer}

The thick sequence of Middle Cambrian through Upper Devonian carbonate rocks is grouped into the Lower Carbonate Aquifer. This unit forms the regional aquifer for most of southern Nevada and may locally be as thick as 5,000 $\mathrm{m}(16,400 \mathrm{ft})$. Transmissivities of these rocks appear to vary locally due to varying fracture and fault densities and characteristics.

\section{Upper Clastic Confining Unit}

Late Devonian and Mississippian clastic rocks (argillites, shales, siltstones, and quartzites) in the NTS vicinity have been assigned to the Eleana and Chainman Shale Formations (Trexler et al., 1996). These two formations are referred to as the Upper Clastic Confining Unit. The Upper Clastic Confining Unit is not believed to be present under Frenchman Flat because of erosion. It is, however, present northwest of the Cane Spring Fault (see the location of the Chainman Shale Formation on Figure 3-3) and may account, in part, for the elevated water levels measured near the Control Point Basin (Winograd and Thordarson, 1975).

\subsection{Tertiary-Age HSUs in the Frenchman Flat Area}

Tertiary-age strata are organized into two major HSUs (Table 3-3) that correspond to layers of the regional geologic model (IT, 1996d): the Volcanic Confining Unit and the Volcanic Aquifer Unit. Each of these units is discussed separately in ascending stratigraphic order in the following text. 


\section{Volcaniclastic Confining Unit}

The Volcanic Clastic Confining Unit, which cover the northern two-thirds of Frenchman Flat, consists of the Volcaniclastic Confining Unit and the Tuff Confining Unit (Lower).

The Volcaniclastic Confining Unit is made up of Tertiary sedimentary rocks that are exposed south and southwest of Frenchman Flat. These rocks are divided into two formations: Rocks of Winapi Wash and the younger, more extensive, Rocks of Pavits Spring. These units consist of a diverse assemblage of interbedded volcanic and sedimentary rocks deposited primarily in lacustrine and fluvial environments. Specific lithologies include ash-flow, ash fall, and reworked tuffs; shale; tuffaceous and argillaceous sandstones; siltstones and mudstones; conglomerates; and lesser limestone (Hinrichs, 1968; Barnes et al., 1982). The Tertiary sedimentary rocks are probably present beneath most of southern and central portions of Frenchman Flat, but transition into a tuff facies to the north (Figure 3-5).

The lower part of the Volcanic Confining Unit consists of the Tuff Confining Unit (Lower). This HSU consists of several zeolitized nonwelded to partially welded ash-flow tuffs. These units are defined by Winograd and Thordarson (1975) as the "tuff aquitard." These rocks are absent over the structural highs south of the Rock Valley fault where the volcanic rocks have been removed by erosion.

\section{Volcanic Aquifer}

The Volcanic Aquifer includes two HSUs: the Wahmonie Lava-Flow Aquifer and the Welded Tuff Aquifer. The lowermost portion in the Wahmonie Lava-Flow Aquifer. This aquifer unit consists of rocks of the Wahmonie Formation (with the Salyer member), which include rhyodacitic and dacitic lava flows, flow breccias, ash-flow, air-fall, and reworked tuffs (Poole et al., 1965). The lava and breccia flows tend to be restricted in areal extent, but the ash-flow units and the air-fall tuffs have a much wider distribution. Lavas and flow breccias predominate in the western third of Frenchman Flat while air-fall and reworked tuffs are the primary Wahmonie units found in the eastern part of the basin. The upper portion of the Volcanic Aquifer corresponds to the Tuff Confining Unit which is made up of nonzeolized volcanic rocks that include welded-tuffs and vitric-tuffs. The welded tuffs include ash-flow-tuff portions of the Rainier Mesa Tuff and Ammonia Tanks Tuff of the Timber 
Mountain Group and the welded Topopah Spring Tuff of the Paintbrush Group. The nonwelded portions of these units form vitric-tuff aquifers. Although these younger volcanic rocks are fairly thick in extreme northern Frenchman Flat (Hinrichs and McKay, 1965), they thin southward in the subsurface (Figure 3-5).

\subsection{Quaternary-Age HSUs in the Frenchman Flat Area}

The only HSU of Quaternary age found in the Frenchman Flat area is the unconsolidated Alluvial Aquifer. Some of the material that comprises the Alluvial Aquifer is also Tertiary age.

The alluvium in Frenchman Flat is a loosely consolidated mixture of silicic volcanic and Paleozoic sedimentary rock detritus, ranging in particle size from clay to boulders. Sediment deposition is largely in the form of alluvial fans (debris flows, sheet wash, and braided streams) that coalesce to form highly discontinuous, gradational, and poorly sorted deposits. Eolian sands and playa deposits are also present within the alluvium section. The basalt flow(s) that have been identified within the alluvium section in drill holes UE-5i (Dixon et al., 1967) and UE-5k (Byers and Miller, 1966) are fairly limited in areal extent and thickness; therefore, they are included in the Alluvial Aquifer. Mid-basin alluvium thickness in Frenchman Flat generally ranges from about $400 \mathrm{~m}(1,300 \mathrm{ft})$ to perhaps as much as $900 \mathrm{~m}(3,000 \mathrm{ft})$.

The extent of the Alluvial Aquifer is coincident with the physiographic boundary of Frenchman Flat. However, due to the moderately deep water table in Frenchman Flat, the alluvium is generally unsaturated, except in the deep subbasins of central Frenchman Flat. These sediments are quite porous and, thus, have high storage coefficients. Transmissivities may also be high, particularly in the coarser, gravelly intervals.

Sample data from drill holes in the Area 5 Radioactive Waste Management Site vicinity indicate that the alluvium is homogeneous (REECo, 1994). Furthermore, available hydrologic data show that the alluvium is isotropic with respect to hydrologic properties (Sully et al., 1993).

\subsection{Groundwater}

Data regarding groundwater levels, gradients, and flow directions are limited due to a small number of sampling locations. The available data are presented in Figure 3-7. The depth to groundwater is 


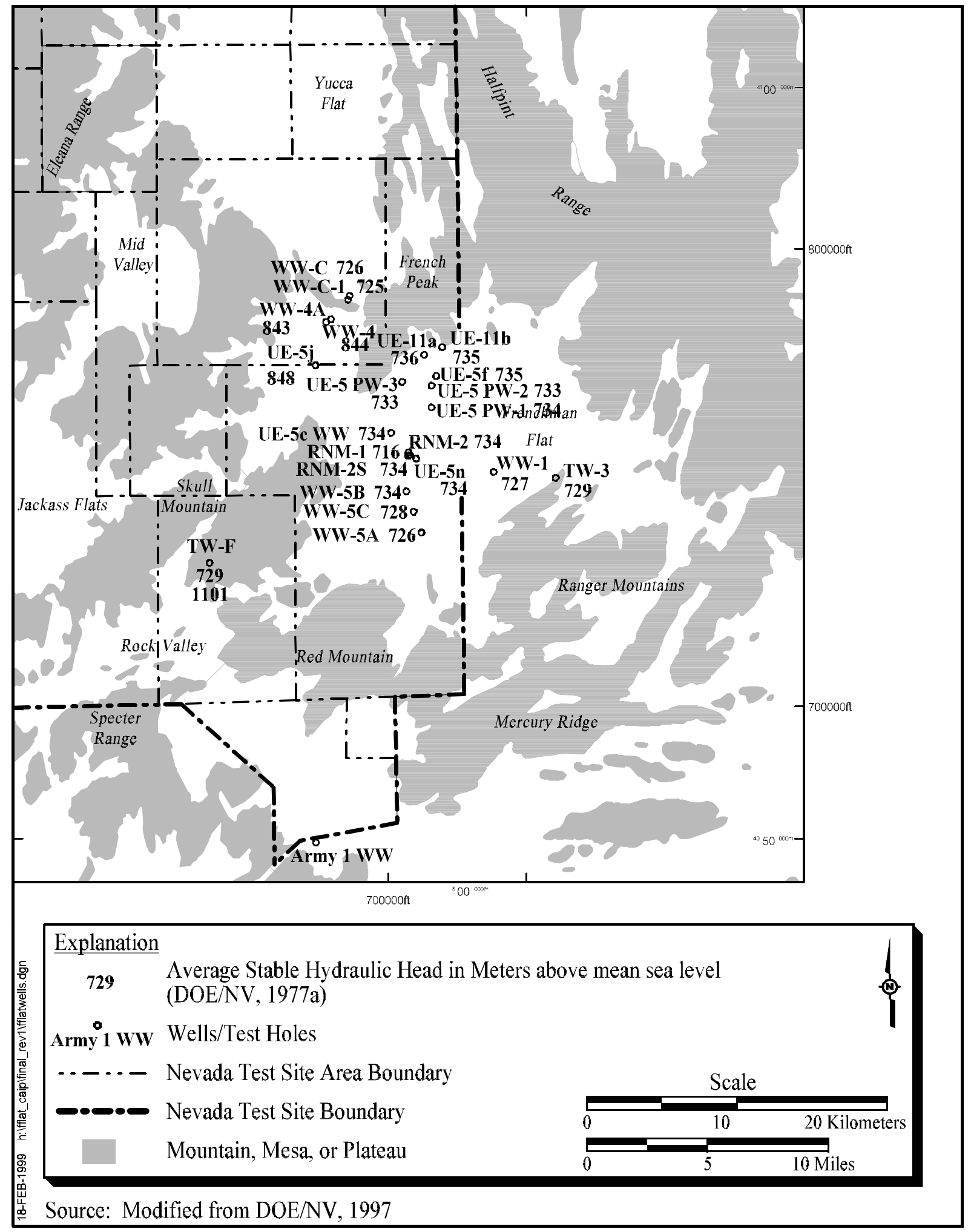

Figure 3-7

Location of Wells and Average Water Levels within Frenchman Flat and Vicinity 
approximately $157 \mathrm{~m}(515 \mathrm{ft})$ beneath Frenchman Flat, with the water table being in the alluvial material (Winograd and Thordarson, 1975).

In general, the primary direction of groundwater flow is towards the south, with the Lower Carbonate Aquifer being the HSU responsible for most of the groundwater flow. In addition, horizontal gradients within the volcanic units and alluvium exist and may indicate groundwater flow in several different directions across the basin. Contours of regional hydraulic heads simulated by the regional model are shown in Figure 3-8.

The potentiometric gradient in the Lower Carbonate Aquifer is relatively flat and trends to the southwest. The small hydraulic gradient in the carbonate aquifer likely reflects a large hydraulic conductivity due to fracturing. In the Alluvial Aquifer, the potentiometric surface is also relatively flat over much of Frenchman Flat. The hydraulic head in the Alluvial Aquifer and volcanic units tends to be higher than in the Lower Carbonate Aquifer except south of the Frenchman Flat Playa, where limited hydraulic head data could be interpreted as showing similar values in the vicinity of the Rock Valley Fault Zone. The separate head values in northern and western Frenchman Flat have been interpreted as indicative of a semiperched condition in the Alluvial Aquifer or volcanics. The hydraulic head differential also indicates that the amount of vertical flow is small. Vertical flow may occur locally along faults themselves or from one aquifer to another if the displacement along a fault is great enough. In general, groundwater flow appears to be predominantly horizontal in both the Alluvial Aquifer and Lower Carbonate Aquifer. However, the influence of faults in the northern testing area of Frenchman Flat is not fully understood at this time.

\subsubsection{Groundwater Geochemistry}

This section provides a brief summary of the chemistry of Frenchman Flat groundwater. Information on general chemistry and the stable isotope composition, plus carbon-14 $\left({ }^{14} \mathrm{C}\right)$, are presented. The radiochemistry of groundwater is discussed in Section 3.4.7.

Groundwater chemistry data are available for 19 of the wells located in Frenchman Flat and the surrounding area (Figure 3-7). These data were obtained from the DOE/NV ERP water quality data base. The predominant sources of the data are BN, DOE/NV, DRI, LANL, LLNL, Reynolds Electrical \& Engineering Company, Inc., U.S. Environmental Protection Agency (EPA), and USGS. 


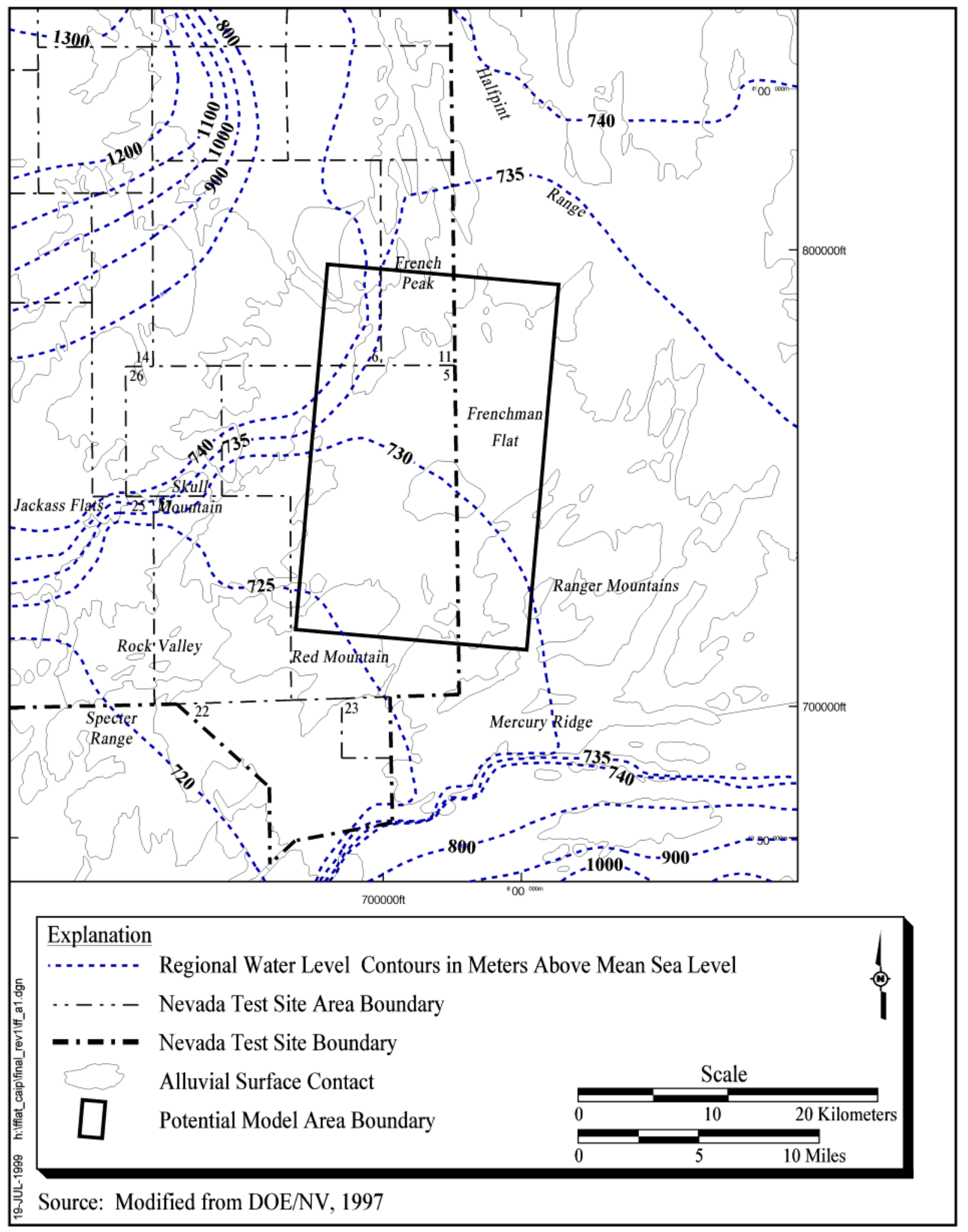

Figure 3-8 
For the Alluvial Aquifer and volcanic HSUs, data are available for wells located within Frenchman Flat. However, because no wells are completed in the Lower Carbonate Aquifer within Frenchman Flat, the groundwater chemistry data for the Lower Carbonate Aquifer includes data from wells located in areas surrounding Frenchman Flat.

\subsubsection{General Chemistry}

The following three hydrochemical water types were identified for groundwater from Frenchman Flat and vicinity (based on a classification scheme presented in Schoff and Moore, 1964). The types of water are identified below using their chemical composition, with atomic symbols, sodium $(\mathrm{Na})$, potassium $(\mathrm{K})$, Magnesium $(\mathrm{Mg})$, and carbonate $\left(\mathrm{HCO}_{3}\right)$ :

Na-K-HCO 3 water type: Sodium and potassium together are 60 percent or more of the total cations. For Frenchman Flat groundwater, sodium is generally dominant, and potassium is negligible.

Ca-Mg-HCO 3 water type: Calcium plus magnesium are 60 percent or more of the total cations. Calcium concentrations are generally slightly greater than magnesium concentrations.

Ca-Mg-Na-HCO 3 water type (mixed type): Neither cation pair amounts to as much as 60 percent of the total cations.

Figure 3-9 is a trilinear diagram showing the average relative concentrations of major ions in groundwater from Frenchman Flat and vicinity. In general, the $\mathrm{Na}-\mathrm{K}-\mathrm{HCO}_{3}$ water type is observed in groundwater from the Alluvial Aquifer and volcanic HSUs; this water type plots near the bottom center of the diamond-shaped graph of Figure 3-9. The $\mathrm{Ca}-\mathrm{Mg}-\mathrm{HCO}_{3}$ and $\mathrm{Ca}-\mathrm{Mg}-\mathrm{Na}-\mathrm{HCO}$ (mixed) types are generally observed in groundwater from the Lower Carbonate Aquifer; these water types plot to the left of center on the diamond-shaped graph shown in Figure 3-9. An exception is the mixed type groundwater observed at Water Well 4 and the borderline mixed to $\mathrm{Na}-\mathrm{K}-\mathrm{HCO}_{3}$ type groundwater at Water Well 4A (Figure 3-9). Both of these wells are completed in the Timber Mountain Aquifer, where $\mathrm{Na}-\mathrm{K}-\mathrm{HCO}_{3}$ type water would be expected.

The source of calcium and magnesium in Lower Carbonate Aquifer groundwater is dissolution of calcite and dolomite mineralogy. Groundwater in volcanic HSUs and the Alluvial Aquifer gains its predominant cation, sodium, from reaction with volcanic glass (White et al., 1980). Where wells 


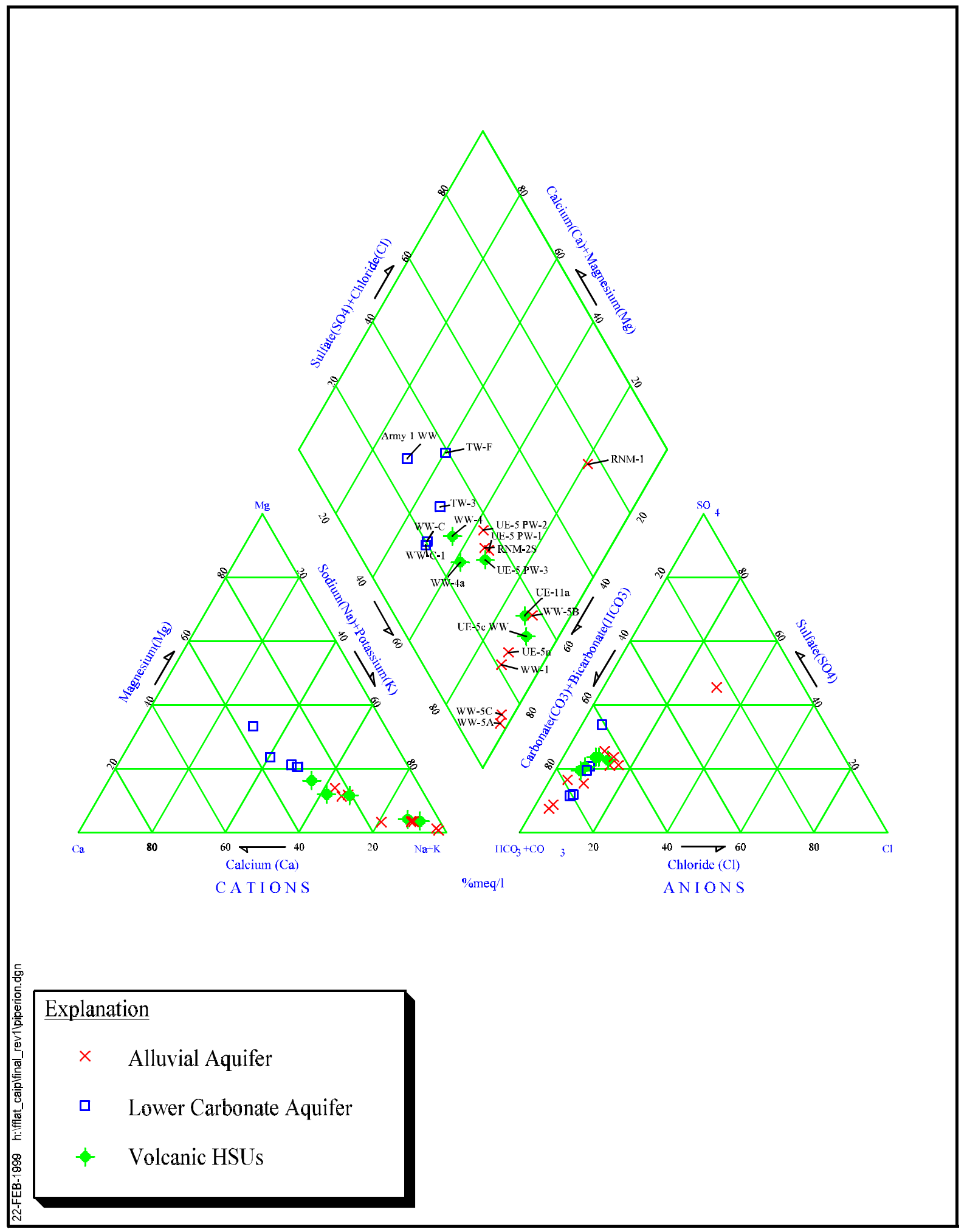

Figure 3-9

Piper Diagram Showing Major lon Concentration Percentages for Frenchman Flat Groundwater Using Average Concentration Data 
exist in the Alluvial Aquifer beneath Frenchman Flat, the alluvium probably consists of material derived from volcanic bedrock, because the groundwater chemical signature of the Alluvial Aquifer is similar to that of the volcanic HSUs. The predominant anionic constituent in groundwater, bicarbonate, is derived from incorporation of carbon dioxide $\left(\mathrm{CO}_{2}\right)$ gas and dissolution of carbonate minerals. Sulfate minerals are highly soluble, and therefore, the relatively low concentrations of dissolved sulfate in Frenchman Flat groundwater indicate that sulfate minerals are generally not present in the subsurface at Frenchman Flat. Mixed water types indicate that groundwater has moved from one rock type or HSU into another somewhere along the flow path.

Figure 3-9 shows that with the exception of Well RNM-1 groundwater, the other groundwater compositions plot along a trend line, particularly the cations. At one end of the cation trend line are the $\mathrm{Ca}-\mathrm{Mg}-\mathrm{HCO}_{3}$ and mixed-type waters from wells completed in the Lower Carbonate Aquifer. The other cation end member is $\mathrm{Na}-\mathrm{K}-\mathrm{HCO}_{3}$ groundwater from wells in the Alluvial Aquifer. The cationic composition of these waters is greater than 90 percent sodium. Compared to groundwater from the Lower Carbonate Aquifer, all waters from the Alluvial Aquifer and volcanic HSUs contain a greater proportion of sodium relative to calcium and magnesium. The trend line indicates that both calcium and magnesium decrease as sodium increases.

A trend line similar to that observed for cations is also observed for anions (Figure 3-9). However, unlike the cationic composition, separation by HSU is not observed based on anions. Groundwater from Frenchman Flat and vicinity range from approximately 60 to 90 percent carbonate and bicarbonate (predominantly bicarbonate), 10 to 30 percent sulfate, and 5 to 15 percent chloride. The anionic trend line indicates that, on a relative basis, both sulfate and chloride decrease as bicarbonate increases.

Figure 3-9 shows that two separate groups of $\mathrm{Na}-\mathrm{K}-\mathrm{HCO}_{3}$ type groundwaters are present in Frenchman Flat. The cation composition of one group is greater than 30 percent calcium plus magnesium, while calcium plus magnesium of the other group is no more that 10 percent of the total cation milliequivalents. One possible explanation for this observation is that the ion exchange process may limit the calcium and magnesium of the latter group to lower concentrations than would otherwise be possible based on mineral saturation constraints. Alteration products of volcanic minerals and alluvium derived from volcanics include mineral phases with high cation exchange 
capacities, e.g., montmorillonite and zeolites (Borg et al., 1976 and White et al., 1980). Given the ion exchange series for montmorillonite shown in Fiero et al. (1974), calcium and magnesium will be preferentially removed from groundwater and replaced with sodium. Thus, some of the differences in the major-ion chemistry observed in groundwater from the Alluvial Aquifer and volcanic HSUs may be due to the degree of alteration of the subsurface material; where alteration is more pervasive, ion exchange may produce lower concentrations of calcium and magnesium.

Table 3-9 presents general chemistry summary statistics for groundwater from Frenchman Flat and vicinity. In addition to the major constituents discussed above, dissolved silica is also a major constituent of groundwater at Frenchman Flat. Concentrations of silica are generally 20 to 40 milligrams per liter (mg/L) in Lower Carbonate Aquifer groundwater and higher (40 to $80 \mathrm{mg} / \mathrm{L})$ in groundwater from the Alluvial Aquifer and volcanic HSUs (Table 3-9). The total dissolved solids (TDS) content of groundwater beneath Frenchman Flat ranges from approximately 200 to $600 \mathrm{mg} / \mathrm{L}$. Relatively high TDS (greater than $600 \mathrm{mg} / \mathrm{L}$ ) are observed at Well RNM-1, where groundwater has been impacted by an underground nuclear test, and at Water Wells $\mathrm{C}$ and $\mathrm{C}-1$, which are completed in the Lower Carbonate Aquifer at the south end of Yucca Flat (Figure 3-7). The pH of Frenchman Flat groundwater is typically 7.0 to 8.5 . The chemistry of Frenchman Flat groundwater suggests that relatively oxidizing conditions exist, i.e., nitrate and dissolved oxygen are present, and iron and manganese concentrations are generally low (Table 3-9).

\subsubsection{Stable and Environmental Isotopes}

Table 3-10 presents a summary of the stable isotope and ${ }^{14} \mathrm{C}$ age data for groundwater from Frenchman Flat and vicinity. The stable isotopes are reported in the conventional delta $(\delta)$ notation as per mil deviations from Standard Mean Ocean Water for hydrogen and oxygen and deviations from the Peedee Belemnite standard for carbon. Both adjusted and unadjusted ${ }^{14} \mathrm{C}$ ages are given in Table 3-10.

Adjusted ages are corrected to account for reactions that affect the ${ }^{14} \mathrm{C}$ activity of groundwater. The adjusted ages are presented as reported; no adjustments were made to the data as part of this CAIP.

Under ambient temperature and pressure conditions, significant isotopic fractionation of hydrogen and oxygen does not occur in the groundwater environment. Isotopic fractionation is defined as a 
Table 3-9

General Chemistry Summary Statistics for Wells Located in Frenchman Flat and Vicinity (Page 1 of 3 )

\begin{tabular}{|c|c|c|c|c|c|c|c|c|c|c|c|c|c|c|c|c|c|c|c|c|}
\hline Well Name & & Army 1 & RNM-1 & RNM-2S & TW-F & TW-3 & UE-11a & $\begin{array}{l}\text { UE-5 } \\
\text { PW-1 }\end{array}$ & $\begin{array}{c}\text { UE-5 } \\
\text { PW-2 }\end{array}$ & $\begin{array}{l}\text { UE-5 } \\
\text { PW-3 }\end{array}$ & $\begin{array}{c}\text { UE-5c } \\
\text { WW }\end{array}$ & UE-5n & WW-1 & WW-4 & wW-4a & WW-5A & WW-5B & WW-5C & Ww-c & WW-C-1 \\
\hline \multirow[b]{2}{*}{ Aluminum } & Mean & $\overline{0.41}$ & 0.04 & $<<0.13$ & 0.06 & $\overline{\mathrm{ND}}$ & $\overline{\mathrm{ND}}$ & $\overline{\mathrm{ND}}$ & $\overline{\mathrm{ND}}$ & $\overline{\mathrm{ND}}$ & 0.61 & $<0.06$ & $\overline{0.01}$ & $<<0.08$ & $\overline{\mathrm{ND}}$ & 0.22 & 0.45 & $\overline{0.67}$ & 0.52 & 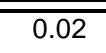 \\
\hline & \begin{tabular}{|l|} 
Std. \\
Dev.
\end{tabular} & 0.46 & 0.04 & 0.1 & 0.06 & ND & ND & ND & ND & ND & 0.49 & NC & NC & 0.03 & ND & 0.1 & 0.47 & 0.46 & 0.48 & 0.02 \\
\hline \multirow[b]{2}{*}{ Barium } & Mean & 0.073 & 0.015 & 0.019 & 0.14 & ND & ND & 0.018 & 0.016 & 0.018 & 0.018 & 0.003 & ND & 0.008 & 0.01 & 0.012 & 0.011 & 0.008 & 0.184 & 0.113 \\
\hline & $\begin{array}{l}\text { Std. } \\
\text { Dev. }\end{array}$ & 0.024 & NC & 0.004 & $\mathrm{NC}$ & ND & ND & 0.003 & 0.004 & 0.002 & $\mathrm{NC}$ & $\mathrm{NC}$ & ND & 0.005 & $\mathrm{NC}$ & $\mathrm{NC}$ & 0.001 & 0.006 & 0.167 & 0.031 \\
\hline \multirow[b]{2}{*}{ Boron } & Mean & 0.22 & 0.24 & 0.24 & ND & ND & ND & ND & ND & ND & 0.25 & 0.31 & 0.15 & 0.2 & 0.2 & 1 & 0.54 & 0.56 & 0.61 & 0.58 \\
\hline & \begin{tabular}{|l|} 
Std. \\
Dev.
\end{tabular} & 0.14 & $\mathrm{NC}$ & NC & ND & ND & ND & ND & ND & ND & $\mathrm{NC}$ & $\mathrm{NC}$ & NC & 0.06 & $\mathrm{NC}$ & 1.13 & 0.43 & 0.3 & 0.09 & 0.06 \\
\hline \multirow[b]{2}{*}{ Calcium } & Mean & 41.8 & 20.4 & 20.5 & 51.5 & 49.9 & 9.1 & 16.3 & 19.2 & 16.4 & 4.5 & 6.7 & 5.6 & 23.4 & 22 & 2.6 & 7.1 & 2.1 & 69.4 & 70.3 \\
\hline & $\begin{array}{l}\text { Std. } \\
\text { Dev. }\end{array}$ & 4.7 & 3.5 & 3.1 & 11.1 & 1.6 & $\mathrm{NC}$ & 1.9 & NA1 & 2.7 & 3.4 & 1.3 & 0.1 & 1 & $\mathrm{NC}$ & 1.3 & 3.5 & 2.4 & 8.8 & 10.4 \\
\hline \multirow[b]{2}{*}{ Iron } & Mean & 0.08 & 0.07 & 0.07 & 0.04 & 0.12 & ND & 0.03 & 0.09 & 0.04 & 0.08 & 0.17 & 0.09 & 0.4 & 0.42 & 0.05 & 0.07 & 0.06 & 0.17 & 0.1 \\
\hline & \begin{tabular}{|l|} 
Std. \\
Dev.
\end{tabular} & 0.09 & 0.06 & 0.01 & 0.05 & $\mathrm{NC}$ & ND & 0.02 & 0.06 & 0.02 & 0.03 & $\mathrm{NC}$ & NC & 0.63 & NC & 0.05 & 0.09 & 0.04 & 0.25 & 0.17 \\
\hline \multirow{2}{*}{ Lithium } & Mean & 0.035 & 0.407 & 0.355 & 0.12 & 0.115 & ND & 0.022 & 0.023 & 0.023 & 0.01 & 0.021 & 0.11 & 0.021 & ND & 0.013 & 0.034 & 0.009 & 0.236 & 0.264 \\
\hline & $\begin{array}{l}\text { Std. } \\
\text { Dev. }\end{array}$ & 0.015 & 0.315 & 0.375 & 0.027 & 0.007 & ND & $\mathrm{NC}$ & $\mathrm{NC}$ & $\mathrm{NC}$ & 0.003 & $\mathrm{NC}$ & $\mathrm{NC}$ & 0 & ND & $\mathrm{NC}$ & 0.011 & 0.004 & 0.089 & 0.093 \\
\hline \multirow[b]{2}{*}{ Magnesium } & Mean & 23.1 & 5.2 & 6.6 & 20 & 20.4 & 2.7 & 5.6 & 7 & 5.6 & 1.8 & 1.7 & 1.6 & 7.8 & 6 & 0.5 & 2 & 0.8 & 30.8 & 28.8 \\
\hline & $\begin{array}{l}\text { Std. } \\
\text { Dev. }\end{array}$ & 2.9 & 3.1 & 1.6 & 6.7 & 0.9 & $\mathrm{NC}$ & 0.3 & $\mathrm{NC}$ & 0.01 & 0.6 & 0.6 & 0.1 & 1 & NC & 0.3 & 0.8 & 1 & 4.4 & 1.7 \\
\hline \multirow[b]{2}{*}{ Manganese } & Mean & 0.04 & 0.03 & 0.04 & 0.05 & ND & ND & 0.02 & 0.03 & 0.01 & 0.06 & 0.02 & $<0.01$ & 0.01 & 0.04 & $<0.01$ & 0.04 & 0.05 & 0.06 & 0.01 \\
\hline & \begin{tabular}{|l|} 
Std. \\
Dev.
\end{tabular} & 0.05 & 0.03 & 0.06 & 0.02 & ND & ND & 0.06 & 0.04 & 0.01 & 0.05 & $\mathrm{NC}$ & $\mathrm{NC}$ & 0.01 & $\mathrm{NC}$ & 0.003 & 0.05 & 0.05 & 0.06 & 0.01 \\
\hline \multirow[b]{2}{*}{ Potassium } & Mean & 5.4 & 11.2 & 9.5 & 9.2 & 8.4 & 4.7 & 6.3 & 6 & 6.6 & 6.3 & 8.4 & 8.8 & 5 & 6 & 6.1 & 11.3 & 6.7 & 14.7 & 14.1 \\
\hline & \begin{tabular}{|l} 
Std. \\
Dev.
\end{tabular} & 1.1 & 3.7 & 1.7 & 0.6 & 1.1 & $\mathrm{NC}$ & 0.4 & $\mathrm{NC}$ & 0.6 & 0.6 & 0.5 & 0.3 & 0.1 & $\mathrm{NC}$ & 0.4 & 1.6 & 1.3 & 3.7 & 0.8 \\
\hline
\end{tabular}


Table 3-9

General Chemistry Summary Statistics for Wells Located in Frenchman Flat and Vicinity

(Page 2 of 3 )

\begin{tabular}{|c|c|c|c|c|c|c|c|c|c|c|c|c|c|c|c|c|c|c|c|c|}
\hline Well Name & & Army 1 & RNM-1 & RNM-2S & TW-F & TW-3 & UE-11a & $\begin{array}{l}\text { UE-5 } \\
\text { PW-1 }\end{array}$ & $\begin{array}{l}\text { UE-5 } \\
\text { PW-2 }\end{array}$ & $\begin{array}{l}\text { UE-5 } \\
\text { PW-3 }\end{array}$ & $\begin{array}{l}\text { UE-5c } \\
\text { WW }\end{array}$ & UE-5n & WW-1 & WW-4 & wW-4a & WW-5A & WW-5B & ww-5c & ww-c & ww-C-1 \\
\hline \multirow[b]{2}{*}{ Sodium } & Mean & 38 & 76 & $\overline{63}$ & 63 & 81 & 106 & $\overline{56}$ & $\overline{51}$ & $\overline{54}$ & $\overline{84}$ & $\overline{82}$ & $\overline{70}$ & $\overline{50}$ & $\overline{55}$ & $\overline{162}$ & $\overline{\overline{96}}$ & $\overline{134}$ & $\overline{129}$ & $\overline{\overline{123}}$ \\
\hline & $\begin{array}{l}\text { Std. } \\
\text { Dev. }\end{array}$ & 2 & 32 & 13 & 2 & 2 & NC & 4 & 4 & 4 & 5 & 6 & 4 & 1 & NC & 3 & 22 & 9 & 15 & 3 \\
\hline \multirow[b]{2}{*}{ Silica } & Mean & 29 & 62 & 48 & 35 & 21 & 60 & 51 & 15 & 41 & 65 & 45 & 78 & 62 & 65 & 52 & 72 & 85 & 47 & 30 \\
\hline & $\begin{array}{l}\text { Std. } \\
\text { Dev. }\end{array}$ & 13 & 6 & 9 & 3 & 5 & $\mathrm{NC}$ & 3 & NC & 3 & 11 & 3 & 9 & 3 & NC & 10 & 42 & 37 & 19 & 2 \\
\hline \multirow[b]{2}{*}{ Strontium } & Mean & 0.74 & 3.42 & 0.16 & 0.57 & 0.89 & ND & 0.1 & 0.19 & 0.11 & 0.06 & 0.05 & 0.03 & 0.15 & ND & 0.1 & 0.05 & 0.12 & 0.7 & 0.78 \\
\hline & \begin{tabular}{|l|} 
Std. \\
Dev.
\end{tabular} & 0.13 & 4.38 & 0.05 & 0.07 & NC & ND & NC & NC & $\mathrm{NC}$ & 0.01 & NC & $\mathrm{NC}$ & NC & ND & 0.05 & 0.02 & 0.14 & 0.27 & 0.07 \\
\hline \multirow[b]{2}{*}{ Bicarbonate } & Mean & 249 & 143 & 170 & 237 & 331 & 217 & 132 & 100 & 134 & 154 & 159 & 170 & 146 & 149 & 342 & 160 & 267 & 505 & 545 \\
\hline & \begin{tabular}{|l} 
Std. \\
Dev.
\end{tabular} & 38 & 23 & 16 & 53 & 10 & NC & 35 & NC & 41 & 17 & 15 & 7 & 11 & 15 & 21 & 17 & 24 & 99 & 53 \\
\hline \multirow[b]{2}{*}{ Carbonate } & Mean & ND & 1 & 12 & ND & ND & ND & 1 & ND & ND & 7 & 19 & ND & 14 & 5 & 24 & 13 & 25 & 31 & 6 \\
\hline & \begin{tabular}{|l} 
Std. \\
Dev.
\end{tabular} & ND & NC & NC & ND & ND & ND & NC & ND & ND & NC & 8 & ND & NC & NC & 10 & 6 & 8 & NC & NC \\
\hline \multirow[b]{2}{*}{ Chloride } & Mean & 17.4 & 75.6 & 19.6 & 12.4 & 23.1 & 24.6 & 10 & 9.6 & 8.9 & 12.8 & 14.9 & 6 & 11.7 & 9 & 11 & 23.9 & 10.7 & 36.3 & 34.3 \\
\hline & \begin{tabular}{|l|} 
Std. \\
Dev.
\end{tabular} & 4.7 & 42.2 & 5.1 & 5.2 & 0.1 & NC & 1 & 2.5 & 0.6 & 2.3 & 3.7 & 0.1 & 1.9 & $\mathrm{NC}$ & 1.9 & 3.5 & 2.7 & 6.2 & 2.9 \\
\hline \multirow[b]{2}{*}{ Fluoride } & Mean & 1 & 1.2 & 0.4 & 3 & 1.5 & ND & 1.3 & 1.1 & 1.3 & 1.9 & 0.8 & 2.1 & 0.8 & 0.8 & 1.8 & 0.8 & 0.9 & 1.1 & 1.1 \\
\hline & \begin{tabular}{|l|} 
Std. \\
Dev.
\end{tabular} & 0.2 & 0.8 & 0.1 & 0.5 & NC & ND & 0.2 & 0.2 & 0.1 & 0.2 & $\mathrm{NC}$ & 0.1 & 0.1 & NC & 0.6 & 0.1 & 0.2 & 0.2 & 0.1 \\
\hline \multirow[b]{2}{*}{ Nitrate } & Mean & 1.4 & 0.5 & 1.8 & 0.3 & 0.5 & 1 & 7.7 & 4.8 & 11.1 & 5.5 & 3.9 & 1.8 & 17.7 & 14.3 & 5.1 & 9.5 & 6 & 0.3 & 0.2 \\
\hline & \begin{tabular}{|l|} 
Std. \\
Dev.
\end{tabular} & 1 & 0.9 & 1 & 0.1 & 0.6 & NC & 4.8 & 3.8 & 5.3 & 2.6 & 3.8 & 0 & 0.6 & NC & 1.4 & 4.7 & 2 & 0.3 & 0.2 \\
\hline \multirow[b]{2}{*}{ Phosphate } & Mean & 0.01 & 0.12 & ND & 0.002 & ND & ND & ND & ND & ND & 0.03 & ND & 0.11 & ND & ND & 0.2 & 0.02 & 0.06 & 0.01 & $<0.01$ \\
\hline & $\begin{array}{l}\text { Std. } \\
\text { Dev. }\end{array}$ & 0.02 & 0.04 & ND & $\mathrm{NC}$ & ND & ND & ND & ND & ND & 0.03 & ND & 0.13 & ND & ND & 0.12 & 0.04 & 0.06 & 0.02 & 0 \\
\hline
\end{tabular}


Table 3-9

General Chemistry Summary Statistics for Wells Located in Frenchman Flat and Vicinity (Page 3 of 3)

\begin{tabular}{|c|c|c|c|c|c|c|c|c|c|c|c|c|c|c|c|c|c|c|c|c|}
\hline Well Name & & Army 1 & RNM-1 & RNM-2S & TW-F & TW-3 & UE-11a & $\begin{array}{l}\text { UE-5 } \\
\text { PW-1 }\end{array}$ & $\begin{array}{l}\text { UE-5 } \\
\text { PW-2 }\end{array}$ & $\begin{array}{l}\text { UE-5 } \\
\text { PW-3 }\end{array}$ & $\begin{array}{l}\text { UE-5c } \\
\text { WW }\end{array}$ & UE-5n & WW-1 & WW-4 & WW-4a & WW-5A & WW-5B & WW-5C & WW-C & WW-C-1 \\
\hline \multirow[b]{2}{*}{ Sulfate } & Mean & 52 & 145 & 43 & 105 & 75 & 60 & 35 & 29 & 32 & 46 & 32 & 28 & 39 & 35 & 26 & 54 & 25 & 66 & 65 \\
\hline & $\begin{array}{l}\text { Std. } \\
\text { Dev. }\end{array}$ & 6 & 95 & 8 & 51 & 12 & $\mathrm{NC}$ & 2 & 1 & 2 & 5 & 9 & 14 & 7 & NC & 7 & 8 & 4 & 9 & 10 \\
\hline \multirow[b]{2}{*}{$\mathrm{pH}$} & Mean & 7.3 & 9.4 & 8.1 & 6.9 & 7.7 & 8.1 & 8.3 & 8.4 & 8.5 & 8.1 & 8.9 & 7.9 & 7.6 & 8.2 & 8.7 & 8.1 & 8.4 & 7 & 7.2 \\
\hline & $\begin{array}{l}\text { Std. } \\
\text { Dev. }\end{array}$ & 0.4 & 1.2 & 0.1 & 0.4 & 0.5 & NC & 0.2 & 0.3 & 0.3 & 0.4 & 0.1 & 0.1 & 0.3 & NC & 0.2 & 0.4 & 0.5 & 0.5 & 0.5 \\
\hline \multirow[b]{2}{*}{ TDS } & Mean & 321 & 601 & 403 & 413 & 444 & 365 & 271 & 223 & 214 & 306 & 214 & 278 & 276 & 283 & 490 & 342 & 384 & 643 & 622 \\
\hline & $\begin{array}{l}\text { Std. } \\
\text { Dev. }\end{array}$ & 34 & 296 & 164 & 85 & NC & $\mathrm{NC}$ & 70 & 69 & 50 & 67 & $\mathrm{NC}$ & 7 & 33 & $\mathrm{NC}$ & 73 & 31 & 39 & 90 & 72 \\
\hline \multirow{2}{*}{ Temperature } & Mean & 31.1 & 21.8 & 25.3 & 64.5 & 36.2 & ND & 20.3 & 22.5 & 20.6 & 25.2 & 25.7 & 24.7 & 28.2 & ND & 22.8 & 24.9 & 24.5 & 34.7 & 34.9 \\
\hline & $\begin{array}{l}\text { Std. } \\
\text { Dev. }\end{array}$ & 1.1 & 2.1 & 0.3 & 0.5 & 2.3 & ND & 3.2 & NC & 5 & 1 & NC & 0.4 & 5.4 & ND & 0.8 & 1.1 & 1 & 3.1 & 3.3 \\
\hline
\end{tabular}

$\mathrm{NC}=$ Only one value present in dataset; standard deviation not calculated $\mathrm{ND}=$ No data available in dataset 
Table 3-10

Stable Isotope and Carbon-14 Data ${ }^{\mathrm{a}}$

\begin{tabular}{|c|c|c|c|c|c|c||}
\hline Well & HSU $^{\mathbf{b}}$ & $\begin{array}{c}\delta^{18} \mathbf{O} \\
(\text { per mil) }\end{array}$ & $\begin{array}{c}\delta \mathbf{D} \\
(\text { per mil) }\end{array}$ & $\begin{array}{c}\delta^{13} \mathbf{C} \\
(\text { per mil) }\end{array}$ & $\begin{array}{c}\text { Unadjusted } \\
\text { Carbon-14 Age } \\
\text { (years before present) }\end{array}$ & $\begin{array}{c}\text { Adjusted } \\
\text { Carbon-14 Age } \\
\text { (years before present) }\end{array}$ \\
\hline \hline Army 1 WW & LCA & -13.4 & -101 & -6.1 & 27566 & 21104 \\
\hline TW-3 & LCA & -14.2 & -104 & -9.2 & 8010 & ND $^{\text {d }}$ \\
\hline UE-5 PW-1 & AA & -13.6 & -106 & -7.3 & 14790 & ND \\
\hline UE-5 PW-2 & AA & ND & ND & ND & 8979 & ND \\
\hline UE-5 PW-3 & TMA & -13.3 & -103 & -7.6 & 13751 & ND \\
\hline UE-5c WW & WVCU & -13.8 & -105 & -7.5 & 22354 & ND \\
\hline UE-5n & AA & -13.5 & -110 & ND & ND & 12600 \\
\hline WW-4 & AA & -12.6 & -94 & -10.9 & 13731 & 13790 \\
\hline WW-5B & AA & ND & ND & -11.7 & 14000 & ND \\
\hline WW-5C & AA & -14.0 & -105 & -6.0 & 28648 & 33615 \\
\hline WW-C & LCA & -13.6 & -106 & -4.2 & 42241 & 30400 \\
\hline WW-C-1 & LCA & -13.9 & -107 & -4.1 & 30589 & \\
\hline
\end{tabular}

alf more than one value was available, value in table is an arithmetic mean of all values. bHydrostratigraphic Unit

AA - Alluvial Aquifer LCA - Lower Carbonate Aquifer TMA - Timber Mountain Aquifer WVCU - Wahmonie Volcanic Confining Unit

'Per mil - deviations from Standard Mean Ocean Water for hydrogen and oxygen, and deviations from the Peedee Belemnite standard for carbon

${ }^{\mathrm{N} N o}$ data

$\delta^{13} \mathrm{C}=$ Delta Carbon-13

change in the isotope content of a substance due to evaporation, condensation, freezing, melting, chemical reactions, or biological processes (Freeze and Cherry, 1979). Thus, evaluation of the hydrogen and oxygen isotopic composition of groundwater can provide information on the source(s) of recharge. Variations observed in groundwater delta Deuterium $(\delta \mathrm{D})$ and delta Oxygen-18 $\left(\delta^{18} \mathrm{O}\right)$ data are due to fractionation effects that have occurred during evaporation and precipitation. Figure 3-10 is a plot of the $\delta \mathrm{D}$ versus $\delta^{18} \mathrm{O}$ composition for individual samples of Frenchman Flat groundwater. Also plotted on Figure 3-10 is the Craig meteoric water line (MWL) (Craig, 1961). 


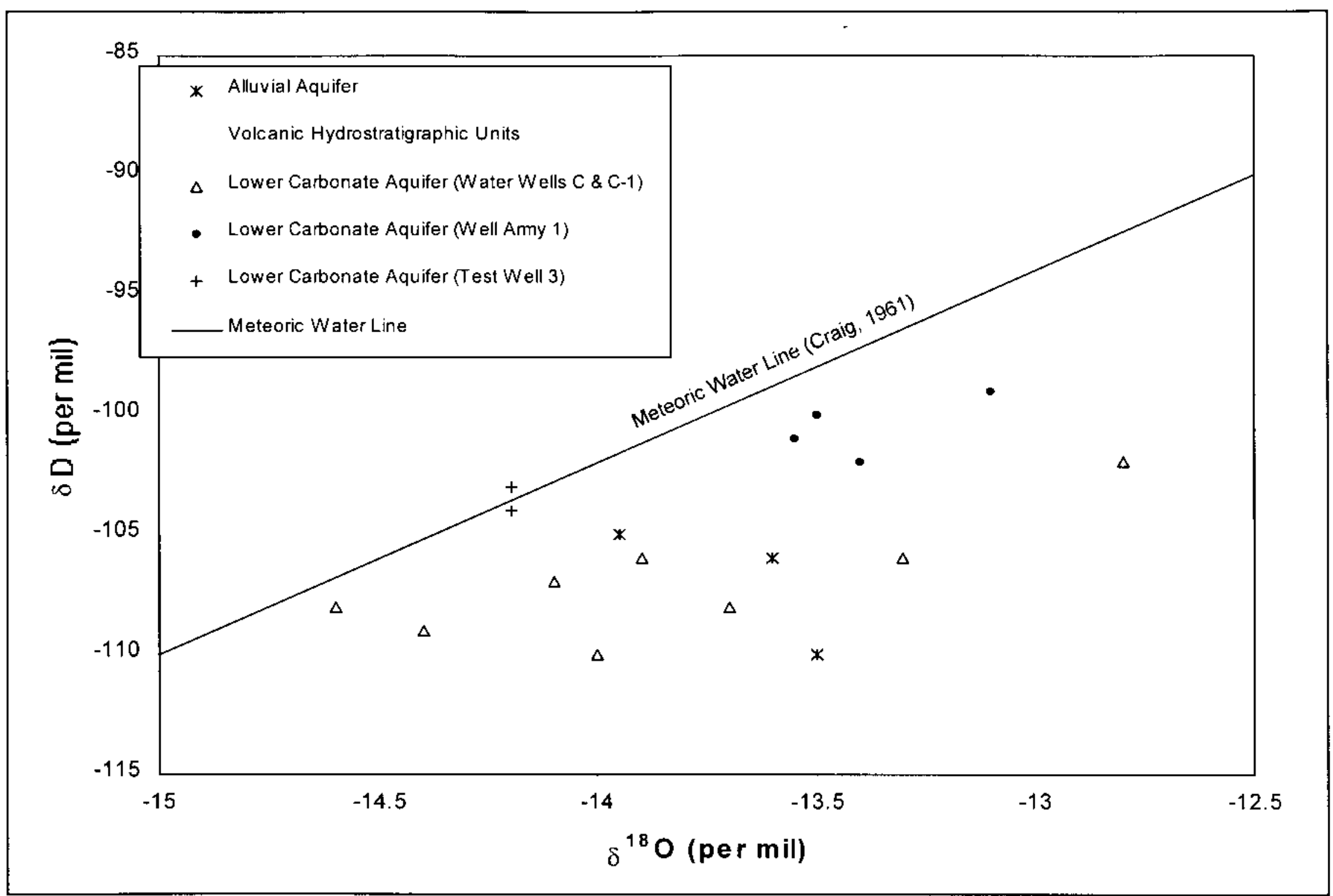

Figure 3-10

Stable Isotope Composition of Groundwater 
The MWL is based on stable isotope data for a large number of analyses of meteoric waters collected at various latitudes. The general trend of Frenchman Flat groundwater data parallels the Craig MWL; however, a slight evaporative shift may be present in the data. The isotopic shift observed in Figure 3-10 may be related to fractionation during evaporation of rainfall, sublimation of snowpack, or possibly fractionation during infiltration (White and Chuma, 1987). In general, groundwaters that plot on the upper right side of Figure 3-10 were recharged at lower elevations and/or at warmer temperatures compared to groundwaters that plot on the lower left side of the $\delta \mathrm{D}$ versus $\delta^{18} \mathrm{O}$ figure.

The stable isotope data for Lower Carbonate Aquifer Water Wells C and C-1 are generally lighter (more negative $\delta \mathrm{D}$ values as shown in Figure 3-10) compared with data from other wells. This implies that Wells C and C-1 were recharged with groundwater from higher altitudes or under colder conditions, compared to groundwater at other wells. However, it must be noted that the scatter in the isotope data for Wells $\mathrm{C}$ and $\mathrm{C}-1$ appears to be greater than expected due to natural variations.

Groundwater from alluvial and volcanic HSU wells are generally heavier (less negative $\delta \mathrm{D}$ values as shown in Figure 3-10) than groundwater from Water Wells C and C-1, possibly indicating recharge at lower elevations or higher temperatures. Figure 3-10 shows that the stable isotope composition of groundwater at Well Army 1 is significantly heavier than the composition measured at other Lower Carbonate Aquifer wells. This suggests a different source for Lower Carbonate Aquifer groundwater at Well Army 1 compared to groundwater at the other Lower Carbonate Aquifer wells in the study area: Water Wells C and C-1, and Test Well 3.

The ${ }^{14} \mathrm{C}$ age of Frenchman Flat groundwater ranges from approximately 8,000 to 29,000 years before present (Table 3-10). The oldest groundwater observed in the entire study area is in the Lower Carbonate Aquifer at Water Wells $\mathrm{C}$ and $\mathrm{C}-1$. Based on ${ }^{14} \mathrm{C}$ activity, the groundwater at these well locations is more than 30,000 years. Relatively young ${ }^{14} \mathrm{C}$ dates $(8,000$ to 14,000 years before present) are observed at well locations on the margins of Frenchman Flat. The locations include Test Well 3, UE-5 PW-2, UE-5 PW-3, and Water Well 4 (Table 3-10).

The oldest ${ }^{14} \mathrm{C}$ ages for volcanic-HSU and Alluvial Aquifer groundwater, greater than 20,000 years before present, are observed in wells that are screened or opened relatively deep in Frenchman Flat (Well UE-5c and Water Well 5C). Excluding these wells, the unadjusted ${ }^{14} \mathrm{C}$ ages of groundwater in 
the Alluvial Aquifer and volcanic HSUs range from approximately 9,000 to 14,800 years before present (Table 3-10). This suggests that groundwater age may increase with increasing depth below the ground surface within the alluvium and volcanic units. However, this conclusion is based on a rather limited set of data.

The delta Carbon-13 $\left(\delta^{13} \mathrm{C}\right)$ of dissolved carbon in groundwater is affected by interactions with carbon in subsurface material. Sources of carbon include both inorganic and organic matter. At the NTS, except possibly near recharge areas, organic carbon is probably not a significant source of carbon for groundwater, and therefore, its affect on the $\delta^{13} \mathrm{C}$ composition is negligible (Thomas, 1996). Excluding organic carbon, the only potential subsurface carbon sources are inorganic carbon contained in carbonate minerals and dissolved $\mathrm{CO}_{2}$ from the soil zone. Carbonate minerals can be primary (i.e., Paleozoic calcite and dolomite of the Lower Carbonate Aquifer) or secondary, which form by precipitation of calcite from groundwater in fractures or as caliche in the unsaturated zone.

Because of differences in the genesis of carbonate minerals in the various water-bearing units, and because the $\delta^{13} \mathrm{C}$ of carbonate minerals varies as a function of genesis, the $\delta^{13} \mathrm{C}$ of groundwater should reflect the $\delta^{13} \mathrm{C}$ of the carbonate minerals along the flow path. This appears to be the case for Frenchman Flat groundwater. Table 3-10 shows that the $\delta^{13} \mathrm{C}$ of groundwater from the Lower Carbonate Aquifer at Water Wells C and C-1 is relatively heavy (enriched in $\delta^{13} \mathrm{C}$ ), approximately -4 per mil (\%o). This probably reflects reaction with primary carbonate minerals. In contrast, the $\delta^{13} \mathrm{C}$ of groundwater from the alluvial and volcanic HSUs may reflect reaction with lighter secondary carbonate minerals, since the $\delta^{13} \mathrm{C}$ of groundwater from these units ranges from -6 to $-11.7 \%$ o (Table 3-10).

\subsubsection{Groundwater Radiological Chemistry}

Radionuclides related to underground nuclear testing in Frenchman Flat are found in groundwater only at wells associated with the CAMBRIC test. At other well locations, only naturally occurring levels of radionuclides have been observed in groundwater. The following discussion is divided into evaluation of data related to the CAMBRIC test and data from wells unrelated to the CAMBRIC test. 


\subsubsection{CAMBRIC Radionuclide Migration Project}

The CAMBRIC Radionuclide Migration (RNM) Project was initiated in 1974 to provide data on the migration of radionuclides away from the site of an underground nuclear test. The area selected for study was the CAMBRIC site. The CAMBRIC test was conducted at a depth of $294 \mathrm{~m}$ (964 ft) bgs in alluvium at Frenchman Flat (Figure 3-1) (Hoffman et al., 1977). One well, RNM-1, was slant-drilled through the radioactive debris and cavity formed by the CAMBRIC test. Another well, RNM-2S,

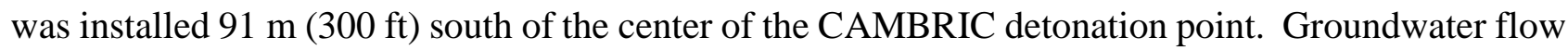
from the detonation point to Well RNM-2S was induced by pumping RNM-2S from October 1975 to August 1991 (Bryant, 1992a). Pumping was necessary to produce an artificial gradient so that water would move to Well RNM-2S in a reasonable length of time. A comprehensive bibliography for the CAMBRIC RNM experiment is presented in Bryant (1992a).

Groundwater at Well RNM-1 was sampled periodically from five isolated zones. The zones were: (1) below the shot cavity, (2) lower cavity, (3) upper cavity, (4) chimney area, and (5) periphery of chimney. Table 3-11 presents average radionuclide concentrations in groundwater from these sampling zones. The samples were collected during 1974 and 1975, approximately ten years after the detonation. Bryant (1992a) reported that no radioactive constituents were detected in groundwater below the bottom of the cavity (Zone 1). Radionuclide concentrations in shot cavity groundwater (Zones 2 and 3) were substantially elevated (Table 3-11). Concentrations of cesium-137 $\left({ }^{137} \mathrm{Cs}\right)$, krypton-85 $\left({ }^{85} \mathrm{Kr}\right)$, strontium-90 $\left({ }^{90} \mathrm{Sr}\right)$, and tritium were also elevated in groundwater samples from the chimney area and periphery of the chimney (Zones 4 and 5). Although elevated, concentrations in the chimney area and periphery were lower compared to concentrations found in the cavity. Antimony-125 $\left({ }^{125} \mathrm{Sb}\right)$, plutonium-239 $\left({ }^{239} \mathrm{Pu}\right)$, and ruthenium-106 $\left({ }^{106} \mathrm{Ru}\right)$ activities were below detection in groundwater samples from the chimney and periphery (Table 3-11).

Figure 3-11 shows the temporal change of radionuclide concentrations in RNM-1 groundwater samples from the chimney and periphery zones (Zones 4 and 5). Except for the first sample (from 1975), which was from Zone 4 only, samples were composites of both zones. Tritium and ${ }^{85} \mathrm{Kr}$ concentrations decreased several orders of magnitude over the period of observation; to a lesser extent, ${ }^{137} \mathrm{Cs}$ and ${ }^{90} \mathrm{Sr}$ concentrations also decreased (Figure 3-11). 
Table 3-11

Radionuclide Concentrations in Groundwater at Well RNM-1

\begin{tabular}{|c|c|c|c|c|c|c|c|c|}
\hline Water Source & Sample Date(s) & $\begin{array}{l}\text { Antimony-125 } \\
(\mathrm{pCi} / \mathrm{L})^{\mathrm{b}}\end{array}$ & $\begin{array}{l}\text { Cesium-137 } \\
\qquad(p \mathrm{pi} / \mathrm{L})\end{array}$ & $\begin{array}{l}\text { Krypton-85 } \\
(\mathrm{pCi} / \mathrm{L})\end{array}$ & $\begin{array}{l}\text { Ruthenium-106 } \\
\qquad(\mathrm{pCi} / \mathrm{L})\end{array}$ & $\begin{array}{l}\text { Strontium-90 } \\
\quad(\mathrm{pCi} / \mathrm{L})\end{array}$ & $\begin{array}{l}\text { Plutonium-239 } \\
\qquad(\mathrm{pCi} / \mathrm{L})\end{array}$ & $\begin{array}{l}\text { Tritium } \\
(\mathrm{pCi} / \mathrm{L})\end{array}$ \\
\hline \multirow[t]{3}{*}{$\begin{array}{l}\text { Lower Cavity } \\
\text { (Zone 2) }\end{array}$} & $9 / 5 / 74-9 / 6 / 74$ & $2.2 \times 10^{+3}$ filtered & $5.9 \times 10^{+2}$ filtered & no data & $3.6 \times 10^{+3}$ filtered & no data & \multirow[t]{2}{*}{$6.3^{\mathrm{c}, \mathrm{d}}$} & \multirow[t]{2}{*}{$1.9 \times 10^{+9 c}$} \\
\hline & $9 / 5 / 74-9 / 6 / 74$ & $\begin{array}{l}1.4 \times 10^{+3} \\
\text { unfiltered }\end{array}$ & $\begin{array}{l}6.1 \times 10^{+2} \\
\text { unfiltered }\end{array}$ & no data & $\begin{array}{l}4.0 \times 10^{+3} \\
\text { unfiltered }\end{array}$ & $\begin{array}{l}4.0 \times 10^{+3} \\
\text { unfiltered }\end{array}$ & & \\
\hline & $11 / 5 / 74-1 / 31 / 75$ & $4.2 \times 10^{+3}$ & $6.7 \times 10^{+2}$ & $1.6 \times 10^{+5 c}$ & $4.0 \times 10^{+3}$ & $2.9 \times 10^{+3}$ & $1.3^{\mathrm{c}}$ & $5.3 \times 10^{+9}$ \\
\hline $\begin{array}{l}\text { Upper Cavity } \\
\text { (Zone 3) }\end{array}$ & $4 / 29 / 75$ & $9.8 \times 10^{+2}$ & $1.5 \times 10^{+3}$ & $2.3 \times 10^{+5 c}$ & $1.9 \times 10^{+3}$ & $2.6 \times 10^{+3}$ & $1.2^{\mathrm{c}}$ & $3.7 \times 10^{+9}$ \\
\hline $\begin{array}{c}\text { Chimney Area } \\
\text { (Zone 4) }\end{array}$ & $8 / 7 / 75-8 / 8 / 75$ & not detected ${ }^{c}$ & $3.7 \times 10^{+2}$ & $1.6 \times 10^{+4}$ & not detected ${ }^{c}$ & $1.8 \times 10^{+3}$ & not detected ${ }^{c}$ & $7.5 \times 10^{+7}$ \\
\hline $\begin{array}{c}\text { Periphery of } \\
\text { Chimney (Zone 5) }\end{array}$ & $8 / 13 / 75-8 / 14 / 75$ & not detected ${ }^{c}$ & $8.2 \times 10^{+1}$ & $3.1 \times 10^{+3}$ & not detected ${ }^{c}$ & $8.2 \times 10^{+1}$ & not detected ${ }^{\mathrm{C}}$ & $2.8 \times 10^{+7}$ \\
\hline
\end{tabular}

${ }^{\mathrm{a}}$ Sample dates from Hoffman et al. (1977)

${ }^{b}$ Picocurie(s) per liter

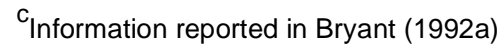

${ }^{d}$ Data from 9/5/74 - 9/6/74 Zone II samples not differentiated into filtered and unfiltered. 


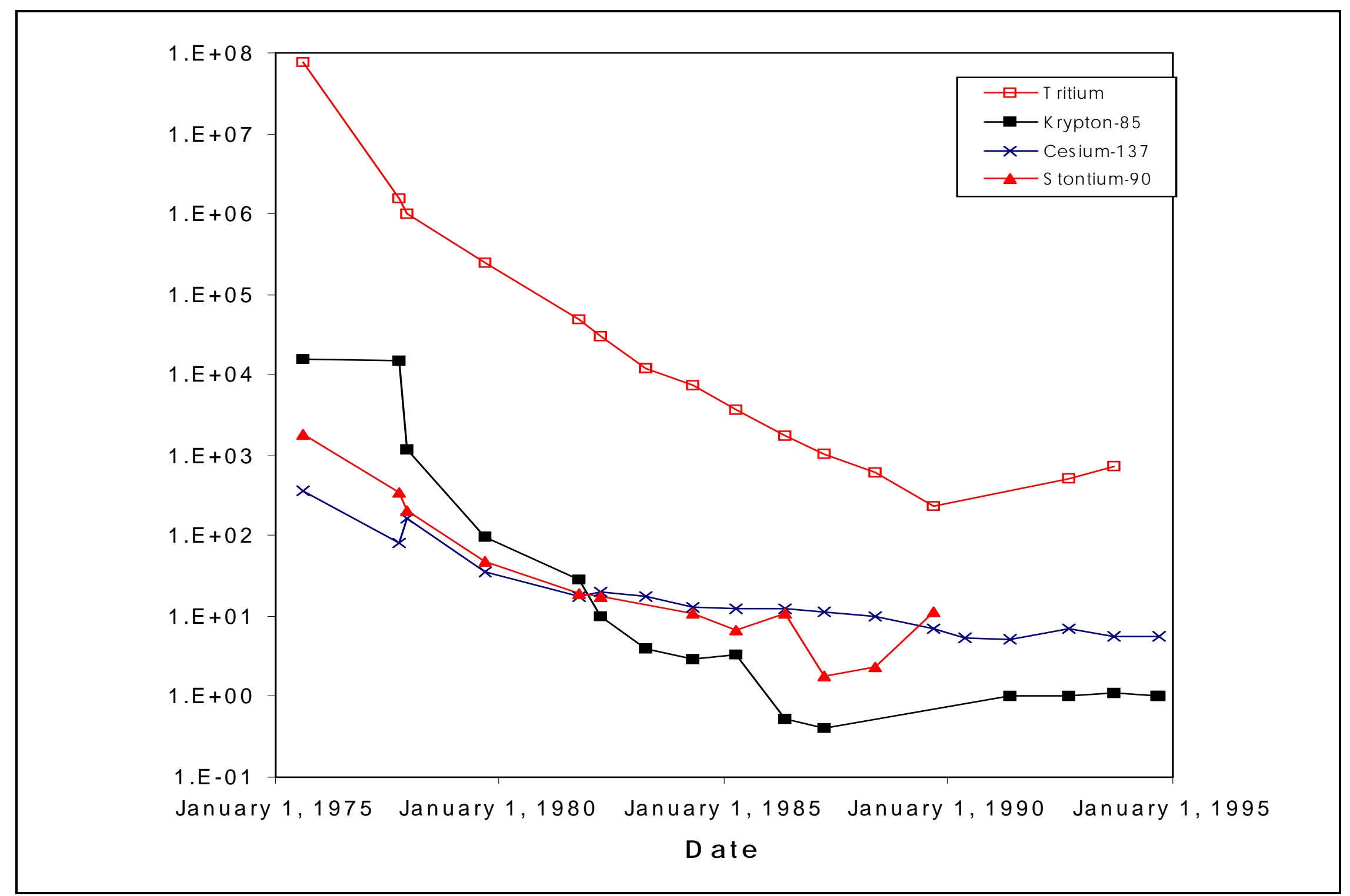

Figure 3-11

Radionuclide Concentrations in Groundwater at Well RNM-1 
Figure 3-12 shows radionuclide concentrations in groundwater at RNM-2S as a function of time. Tritium, ${ }^{85} \mathrm{Kr}$, chlorine-36 $\left({ }^{36} \mathrm{Cl}\right),{ }^{106} \mathrm{Ru}$, and iodine-129 $\left({ }^{129} \mathrm{I}\right)$ were transported in groundwater from the CAMBRIC cavity/chimney area to Well RNM-2S. These radionuclides are all known to be relatively mobile in the groundwater environment. Tritium forms tritiated water and should ideally move at the same velocity as groundwater. Krypton is a dissolved gas, and the other radionuclides are generally present in groundwater as anionic constituents. The radionuclides ${ }^{137} \mathrm{Cs},{ }^{239} \mathrm{Pu},{ }^{125} \mathrm{Sb}$, and ${ }^{90} \mathrm{Sr}$ were not detected in RNM-2S groundwater, although these radionuclides were present in groundwater samples from the CAMBRIC cavity (Table 3-11). Cesium and strontium are generally cationic, do not readily form complexes, and therefore, may be sorbed (Borg et al., 1976). Plutonium is typically very insoluble (Bryant, 1992a). Apparently these radionuclides are not migrating from the CAMBRIC detonation point, are migrating very slowly, or are migrating at very low concentrations.

Maximum tritium concentrations were observed at Well RNM-2S in late 1980, and peak ${ }^{85} \mathrm{Kr}$ concentrations were observed in mid-1981 to 1982 . The concentration maxima for ${ }^{36} \mathrm{Cl}$ and ${ }^{106} \mathrm{Ru}$ appear to have arrived at RNM-2S sooner than peak concentrations of tritium and ${ }^{85} \mathrm{Kr}$ (Figure 3-12). As discussed above, tritium forms tritiated water and ${ }^{85} \mathrm{Kr}$ is a dissolved gas. However, both ${ }^{36} \mathrm{Cl}$ and ${ }^{106} \mathrm{Ru}$ are generally present in groundwater as negatively charged ions or complexes. Chlorine typically is present in groundwater as the chloride ion, and ruthenium is thought to form negatively charged complexes (Ames and Rai, 1978). Early arrival of ${ }^{36} \mathrm{Cl}$ and ${ }^{106} \mathrm{Ru}$ may be due to anion exclusion. This phenomenon effectively prevents anionic constituents from entering into the intragranular porosity of aquifer materials (Ogard et al., 1988).

As noted by Davisson et al. (1994), groundwater at Well UE-5n (Figure 3-7) has apparently been contaminated by radionuclides from the CAMBRIC RNM experiment. The ${ }^{36} \mathrm{Cl}$ and tritium concentrations in groundwater at Well UE-5n (2.1 x $10^{-2}$ and 9,822 picocuries per liter, respectively) were elevated relative to background at the time of sampling (May 1993). Although not part of the CAMBRIC experiment, Well UE-5n is located near a discharge ditch that was used to transport the water pumped from Wells RNM-1 and RNM-2S to Frenchman Lake. Apparently, some of the contaminated water migrated into the subsurface and reached groundwater near Well UE-5n. 


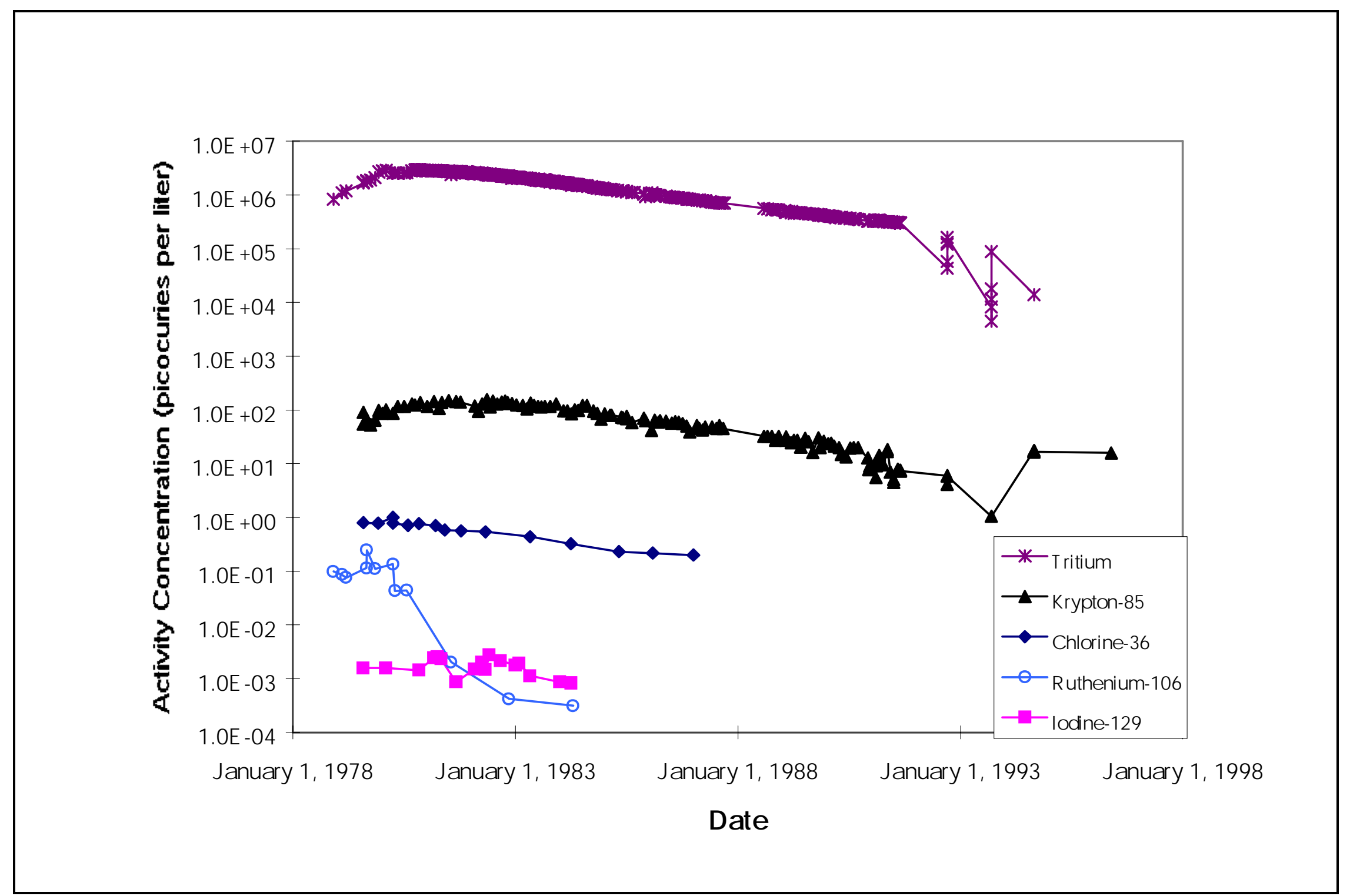




\subsubsection{Non-CAMBRIC Radionuclide Data}

Excluding well locations associated with the CAMBRIC RNM Project, radionuclide concentrations measured in Frenchman Flat groundwater are low. Unfortunately, analytical uncertainty is relatively high at background concentrations, and therefore, the radionuclide data are highly variable for groundwater samples from non-CAMBRIC well locations. The variability appears to be primarily an artifact of sampling and/or analysis, rather than related to any environmental process. Also, in many cases, detection limits were too high to quantify radionuclide concentrations.

Table 3-12 presents the concentration range of radionuclides in groundwater at wells not affected by the CAMBRIC nuclear test or subsequent migration experiment. Data reported with high detection limits and negative-concentration data were not included. As discussed in the preceding paragraph, the data must be interpreted with caution. The ${ }^{36} \mathrm{Cl}$, radium isotope, and total and isotopic uranium data shown in Table 3-12 are probably representative of actual concentrations in groundwater at Frenchman Flat. For the other radionuclides listed in the table, this is most likely not true.

A tritium tracer test was conducted between Water Wells C and C-1 in 1964; approximately 0.1 to 0.2 curies of tritium were injected into Well C-1 (Lyles, 1990). The range of tritium concentrations observed in groundwater from Wells $\mathrm{C}$ and C-1 is presented in Table 3-12. Tritium concentrations at both wells have decreased from the early 1970 s to the present.

\subsubsection{Contaminant Transport Parameters}

This section presents data on contaminant transport parameters. The parameters are porosity, dispersivity, the matrix diffusion coefficient, and the distribution coefficient. Colloidal transport is also discussed.

\subsubsection{Porosity}

A summary of the porosity data gathered during the regional evaluation (DOE/NV, 1997 and IT, 1996e), including measured matrix, bulk, and fracture porosities, and effective porosities derived from tracer tests is provided in this section. Porosity influences the movement of contaminants in groundwater because it is an important factor in determining the magnitude of groundwater velocity and matrix diffusion. It should be noted that data from the Phase I report is included in this CAIP, and CAU-specific data analysis may change the porosity dataset. 
Table 3-12

Radionuclide Concentrations in Groundwater ${ }^{\mathrm{a}}$

\begin{tabular}{|c|c|c|c|c|c|c|c|c|c|c|c|c|c|c|}
\hline \multirow{2}{*}{$\begin{array}{c}\text { Radioisotope } \\
\text { (pCi/L, unless } \\
\text { noted })^{\text {b }} \\
\end{array}$} & \multicolumn{5}{|c|}{ Alluvial Aquifer } & \multicolumn{4}{|c|}{ Volcanic Aquifer } & \multicolumn{5}{|c|}{ Lower Carbonate Aquifer } \\
\hline & UE-5 PW-1 & UE-5 PW-2 & WW-5A & WW-5B & wW-5C & UE-5 PW-3 & UE-5c WW & WW-4 & ww-4a & Army 1 & ww-c & ww-C-1 & TW-F & TW-3 \\
\hline Chlorine-36 & $3.4 \mathrm{e}-04$ & $2.7 e-04$ & $N A^{C}$ & $\mathrm{NA}$ & $2.9 e-04$ & $2.3 \mathrm{e}-04$ & $2.9 e-04$ & $3.1 \mathrm{e}-04$ & NA & $3.5 \mathrm{e}-04$ & $2.6 \mathrm{e}-04$ & $2.4 \mathrm{e}-04$ & NA & NA \\
\hline lodine-131 & $\begin{array}{l}0.01 \text { to } \\
1.8 \pm 2.9\end{array}$ & 0.25 & NA & NA & NA & 0.13 to $<1.0$ & NA & NA & NA & NA & NA & NA & NA & NA \\
\hline Plutonium-238 & $\begin{array}{c}0.002 \pm 0.004 \\
\text { to }<0.009\end{array}$ & $\begin{array}{c}<0.006 \text { to } \\
0.007\end{array}$ & NA & NA & NA & $\begin{array}{l}0.003 \text { to } \\
<0.008\end{array}$ & NA & NA & NA & NA & NA & NA & NA & NA \\
\hline $\begin{array}{l}\text { Plutonium-239, } \\
-240\end{array}$ & $\begin{array}{c}0.002 \pm 0.004 \\
\text { to }<0.009\end{array}$ & $\begin{array}{l}0.004 \text { to } \\
<0.006\end{array}$ & NA & NA & NA & $\begin{array}{l}0.001 \text { to } \\
<0.011\end{array}$ & NA & NA & NA & NA & NA & NA & NA & NA \\
\hline Radium-226 & $\begin{array}{c}0.4 \pm 0.2 \text { to } \\
2.2^{\mathrm{d}}\end{array}$ & 0.2 to 1.5 & $<0.1$ to 1.9 & 0.1 to $<0.2$ & 0.1 to $<0.2$ & 0.15 to 2.2 & NA & NA & NA & 0.06 to 0.5 & 1.1 to 1.4 & $1.5 \pm 0.3$ & 0.2 to 4.7 & NA \\
\hline Radium-228 & 0.13 to $<3.3$ & $<0.18$ to 0.36 & NA & NA & NA & 0.96 & NA & $0.5 \pm 0.6$ & NA & 0.4 to $<1$ & $0.7 \pm 0.7$ & $0.7 \pm 0.6$ & NA & NA \\
\hline Strontium-90 & $\begin{array}{l}0.056 \text { to } \\
0.12\end{array}$ & 0.087 to 0.34 & $<6$ & $<5$ & 0.6 to $<3$ & $\begin{array}{c}0.002 \text { to } \\
0.11\end{array}$ & NA & NA & NA & 0.4 to $<0.6$ & $<0.5$ & NA & $<0.6$ & NA \\
\hline Technetium-99 & 0.004 to $<5$ & 0.36 to $<5$ & NA & NA & $<5$ & 0.31 to $<5$ & $<5$ & $<5$ & NA & NA & $<5$ & NA & NA & NA \\
\hline Tritium & $\begin{array}{c}0.3 \pm 0.6 \text { to } \\
2.8^{\text {e }}\end{array}$ & $f$ & NA & $\begin{array}{c}0.35 \pm 8.0 \text { to } \\
10.7 \pm 5.3^{9}\end{array}$ & $\begin{array}{c}0.09 \pm 10.7 \text { to } \\
33.4 \pm 6.6^{\mathrm{h}}\end{array}$ & $\begin{array}{c}1.0 \text { to } \\
3.8 \pm 0.3\end{array}$ & $\begin{array}{c}0.11 \pm 7.4 \text { to } \\
13.8 \pm 5.3^{h}\end{array}$ & $\begin{array}{c}0.13 \pm 11.8 \text { to } \\
17.6 \pm 10.3\end{array}$ & NA & 0.64 to 21.9 & 5.3 to $276^{i}$ & 1.2 to $135^{\mathrm{j}}$ & NA & $<10$ \\
\hline \begin{tabular}{|l} 
Total Uranium \\
$(\mathrm{mg} / \mathrm{L})$
\end{tabular} & $\begin{array}{c}0.002 \text { to } \\
0.006 \pm 0.002\end{array}$ & $\begin{array}{c}<0.001 \text { to } \\
0.006\end{array}$ & $\begin{array}{c}0.002 \text { to } \\
0.021\end{array}$ & $\begin{array}{c}0.005 \text { to } \\
0.007\end{array}$ & $\begin{array}{l}0.004 \text { to } \\
0.007\end{array}$ & $\begin{array}{l}0.004^{\text {to }} \\
0.022^{k}\end{array}$ & 0.005 & $\begin{array}{c}<0.005 \text { to } \\
0.006\end{array}$ & 0.006 & $\begin{array}{l}0.002 \text { to } \\
0.003\end{array}$ & $\begin{array}{c}<0.005 \text { to } \\
0.008\end{array}$ & $\begin{array}{l}0.005 \text { to } \\
0.006\end{array}$ & $\begin{array}{c}0.003 \text { to } \\
0.009^{\prime}\end{array}$ & NA \\
\hline Uranium-234 & NA & NA & NA & $3.0 \pm 0.2$ & $4.6 \pm 0.3$ & NA & NA & $7.1 \pm 0.5$ & $8.3 \pm 0.5$ & $\begin{array}{c}2.5 \pm 0.3 \text { to } \\
2.6 \pm 0.2\end{array}$ & $8.4 \pm 0.5$ & $8.8 \pm 0.6$ & NA & NA \\
\hline Uranium-238 & NA & NA & NA & $2.1 \pm 0.2$ & $2.4 \pm 0.2$ & NA & NA & $2.0 \pm 0.2$ & $2.1 \pm 0.2$ & $\begin{array}{c}0.77 \pm 0.11 \text { to } \\
0.92 \pm 0.11\end{array}$ & $2.3 \pm 0.2$ & $2.3 \pm 0.2$ & NA & NA \\
\hline
\end{tabular}

${ }^{a}$ Does not include groundwater from well locations impacted by the CAMBRIC Test and associated radionuclide migration experiment (See text in Section 3.4.7.2).

${ }^{b}$ Picocuries per liter

${ }^{\mathrm{C}}$ Data are not available

${ }^{\mathrm{d}}$ Concentration of $1,650 \mathrm{pCi} / \mathrm{L}$ is not included in range.

${ }^{\mathrm{e}}$ Concentration of $171 \mathrm{pCi} / \mathrm{L}$ is not included in range.

${ }^{f}$ Data are too variable to establish meaningful range.
${ }^{9}$ Concentrations of $35 \pm 326$ and $86 \pm 11.7 \mathrm{pCi} / \mathrm{L}$ are not included in range.

${ }^{\mathrm{h}}$ Concentration of $83 \mathrm{pCi} / \mathrm{L}$ is not included in range.

' Concentration of $0.13 \pm 12 \mathrm{pCi} / \mathrm{L}$ is not included in range.

j Concentration of $0.25 \pm 10.2 \mathrm{pCi} / \mathrm{L}$ is not included in range.

${ }^{\mathrm{k}}$ Concentration of $5 \times 10^{-5} \mathrm{mg} / \mathrm{L}$ is not included in range.

'Concentration of $1 \times 10^{-4} \mathrm{mg} / \mathrm{L}$ is not included in range. 
Total porosity is often represented by measured bulk porosity, which is a combination of matrix and fracture components. The interconnected pore space through which water may flow is generally represented by the effective porosity. In some geologic media, not all pore spaces are interconnected, so that effective porosity is a fraction of total porosity. Measurements of porosity generally provide bulk, matrix, or fracture porosity values; and effective porosity can be estimated from these measurements. In granular materials, the effective porosity is often only slightly smaller than the bulk porosity. For unfractured granular material of silt size or larger, the matrix porosity may represent a good estimate of the effective porosity. In finer-grained granular material (e.g., argillite of the Eleana and Chainman Formations), the effective porosity will be significantly smaller than the total porosity. In fractured media (e.g., carbonates and welded tuffs), the fracture porosity component generally controls the velocity of groundwater, and thus, fracture porosity may serve as an approximation of the effective porosity. For fractured units, the effective porosity may be several orders of magnitude smaller than bulk porosity.

In fractured media, the fractures are separated by blocks of unfractured rock material that constitute the matrix rock. Contaminants can diffuse into, and sorb onto, the rock matrix. Therefore, the diffusion and adsorption processes are governed, in part, by matrix porosity.

Methods used to measure porosity include laboratory measurements on cores, interpretations of geophysical logs, and solute or tracer migration studies. Data obtained from core measurements generally represent matrix porosity. Geophysical logs used to estimate porosity include density, sonic (velocity), neutron, and resistivity logs. Measurements derived from geophysical logs are more representative of the formation as a whole, and therefore more representative of bulk porosity, rather than a measure of matrix porosity alone. In fractured geologic materials, fracture porosity is best measured using tracer migration tests.

During the regional evaluation, a database of measured porosity values for geologic units of the NTS region was developed using data from the literature (IT, 1996e). Many data points in the porosity database had multiple values of porosity obtained from different methods such as multiple geophysical logs. The dataset was statistically reduced to provide an estimate of the mean and variance of the porosity of each HSU by type. The results for matrix and bulk porosity are provided in Table 3-13. Several conclusions can be drawn from these statistical summaries. First, the alluvial 
Table 3-13

Statistical Summary of Porosity Data

\begin{tabular}{|c|c|c|c|c|c|}
\hline $\begin{array}{c}\text { Hydrostratigraphic } \\
\text { Unit }\end{array}$ & $\begin{array}{l}\text { Porosity } \\
\text { Type }\end{array}$ & $\begin{array}{c}\text { Mean } \\
\text { (percent of bulk } \\
\text { volume) }\end{array}$ & Variance & $\begin{array}{c}\text { Range Min/Max } \\
\text { (percent of } \\
\text { bulk volume) }\end{array}$ & $\begin{array}{l}\text { Number of } \\
\text { Points }\end{array}$ \\
\hline Alluvial Aquifer & Bulk & 36.3 & 79.8 & 10 to 35 & 126 \\
\hline Alluvial Aquifer & Matrix & 25.2 & 32.3 & 13.4 to 38.6 & 18 \\
\hline Basal Aquifer & Bulk & 14.3 & 20.9 & 8.5 to 23 & 9 \\
\hline Basal Aquifer & Matrix & 18.4 & 28.6 & 9.1 to 27.1 & 25 \\
\hline Basal-Confining Unit & Matrix & 38.3 & 13.4 & 33.2 to 45.2 & 16 \\
\hline Belted Range Aquifer & Bulk & 28.4 & 66.6 & 19 to 39 & 7 \\
\hline Lower Carbonate Aquifer & Bulk & 11.7 & 0.3 & 11 to 12 & 3 \\
\hline Lower Carbonate Aquifer & Matrix & 3.8 & 7.5 & 0.3 to 9.9 & 18 \\
\hline $\begin{array}{c}\text { Lower Clastic-Confining } \\
\text { Unit }\end{array}$ & Matrix & 3.3 & 6.5 & 0.2 to 10 & 31 \\
\hline Tuff-Confining Unit & Matrix & 28.1 & 64 & 7.3 to 47.5 & 75 \\
\hline $\begin{array}{c}\text { Topopah Spring Tuff } \\
\text { Aquifer }\end{array}$ & Matrix & 23.7 & $N A^{b}$ & NA & 1 \\
\hline Timber Mountain Aquifer & Bulk & 16.2 & 132.5 & 3.4 to 58.3 & 332 \\
\hline Timber Mountain Aquifer & Matrix & 23.2 & 172.8 & 7 to 54 & 32 \\
\hline $\begin{array}{c}\text { Upper Clastic-Confining } \\
\text { Unit }\end{array}$ & Matrix & 8.8 & 20.6 & 1.3 to 22.6 & 34 \\
\hline Vitric-Tuff Aquifer & Matrix & 34 & 84.3 & 19.9 to 44 & 17 \\
\hline Welded-Tuff Aquifer & Matrix & 20 & 138.1 & 1.4 to 65 & 639 \\
\hline Wahmonie Lava Aquifer & Matrix & 27.4 & 13.8 & 22.3 to 33.5 & 13 \\
\hline Wahmonie Lava Aquifer & Bulk & 16 & 2.8 & 14 to 18.7 & 6 \\
\hline Volcanic-Confining Unit & Matrix & 16 & 13 & 9.2 to 23.5 & 28 \\
\hline
\end{tabular}

Source: IT, 1996e

${ }^{\mathrm{a}}$ Min $=$ Minimum

Max $=$ Maximum

${ }^{\mathrm{b}}$ Not applicable 
and volcanic units have significantly larger porosities than the Paleozoic carbonate and clastic units. Second, the volcanic aquifers (e.g., Timber Mountain Aquifer) are less porous than the volcanic-confining units (e.g., Tuff-Confining Unit) because aquifer units tend to be welded, which reduces the porosity. Differences in volcanic unit porosity values may be attributable to the large variations in lithology, both lateral and vertical, that are inherent in volcanic rocks.

Estimates of effective porosity for geologic units of the NTS were derived from existing tracer test data. Information on the three tracer tests is provided in Table 3-14, along with the estimates for effective porosity. Leap and Belmonte (1992) examined data from the USGS Amargosa Tracer Calibration Site (south of the NTS) and determined an effective porosity of 10 percent for a fractured 10-m (33-ft) thick interval of the Bonanza King dolomite of the Lower Carbonate Aquifer. The 10 percent value may be accurate for the Amargosa site, but it is unlikely to be representative for the NTS. The Amargosa Tracer Site is a very thin (less than $10 \mathrm{~m}[32.8 \mathrm{ft}]$ ) aquifer about $200 \mathrm{~m}$ (656.2 ft) bgs; these conditions are not typical of the study area as a whole. Burbey and Wheatcraft (1986) used an effective porosity of 32 to 36 percent for the alluvium at the CAMBRIC test site in Frenchman Flat. A preliminary assessment of the tracer experiment at Water Wells C and C-1 (Winograd and West, 1962) yielded an effective porosity between 0.064 and 0.5 percent for the Lower Carbonate Aquifer.

To supplement the tracer studies, data from core fractures were used to calculate fracture porosity values on the NTS. Two recent studies of volcanic (Drellack et al., 1997) and carbonate (IT, 1996g) core provided insight into fracture porosity values. A study of core from seven wells from Pahute Mesa was conducted to characterize fractures in the volcanic units (Drellack et al., 1997). In the analysis, only open fractures were included. A range of fracture porosities, calculated from aperture, density, orientation, and percent open-area data are presented in Table 3-15. Core from Well ER-6-2 (IT, 1996g) was examined and described with respect to fracture density (number of fractures per 1.5-m [5-ft] interval), fracture aperture, and fracture dip angle. The fracture porosity is 0.4 percent, which is estimated as the aperture divided by the true spacing. This value compares well with the values obtained from the tracer test conducted at Water Wells C and C-1 (Table 3-14).

In addition, several literature sources for fracture porosity were also examined to determine if the data from the NTS were consistent with other work. Lee and Farmer (1993) summarized a large amount 
Table 3-14

Effective Porosity Estimates from Tracer Tests Conducted at or near the Nevada Test Site

\begin{tabular}{||l|l|c|l|c|c||}
\hline Site Location & \multicolumn{1}{|c|}{$\begin{array}{l}\text { Test Site } \\
\text { Geology }\end{array}$} & $\begin{array}{c}\text { Test Scale } \\
\text { meters (feet) }\end{array}$ & Test Method & $\begin{array}{l}\text { Effective } \\
\text { Porosity } \\
\text { (percent) }\end{array}$ & References \\
\hline \hline $\begin{array}{l}\text { Amargosa } \\
\text { Nesert, near }\end{array}$ & $\begin{array}{l}\text { Fractured } \\
\text { Cambrian } \\
\text { Bonanza } \\
\text { King Dolomite }\end{array}$ & $\begin{array}{l}122.8 \\
(403)\end{array}$ & $\begin{array}{l}\text { Doublet } \\
\text { recirculation } \\
\text { (tritium, } \\
\text { sulfur-35, } \\
\text { bromide) }\end{array}$ & 10 & $\begin{array}{l}\text { Leap \& } \\
\text { Belmonte, } 1992\end{array}$ \\
\hline Yucca Flat, NTS & $\begin{array}{l}\text { Fractured } \\
\text { Limestone }\end{array}$ & $\begin{array}{l}29.3 \\
(96)\end{array}$ & $\begin{array}{l}\text { Radial } \\
\text { converging } \\
\text { test at Water } \\
\text { Wells C and C-1 } \\
\text { (fluorescein) }\end{array}$ & 0.064 to 0.5 & Winograd \& \\
West, 1962 \\
\hline $\begin{array}{l}\text { CAMBRIC Site, } \\
\text { Frenchman Flat, } \\
\text { NTS }\end{array}$ & $\begin{array}{l}\text { Tuffaceous } \\
\text { Alluvium }\end{array}$ & $\begin{array}{l}\text { Radial } \\
\text { converging with } \\
\text { monitoring the } \\
\text { elutions of tritium } \\
\text { and chlorine-36 } \\
\text { at pumping well } \\
\text { RNM-2S }\end{array}$ & 31 to 35 & $\begin{array}{l}\text { Burbey \& } \\
\text { Wheatcraft, } \\
1986\end{array}$ \\
\hline
\end{tabular}

Sources: IT, 1996e

Table 3-15

Fracture Porosity Obtained from the Study of Volcanic Core

\begin{tabular}{|c|c|}
\hline Hydrostratigraphic Unit & Fracture Porosity Range (percent) \\
\hline \hline Uppermost Welded Tuffs & $2.2 \times 10^{-3}$ to $5.6 \times 10^{-3}$ \\
\hline Tuff Cones & $2.6 \times 10^{-4}$ to $1.3 \times 10^{-2}$ \\
\hline Welded Tuffs Above Basal Confining Unit & $1.2 \times 10^{-3}$ to $1.2 \times 10^{-2}$ \\
\hline Basal Aquifer & $6.1 \times 10^{-4}$ to $6.1 \times 10^{-3}$ \\
\hline
\end{tabular}


of information on fluid flow in fractured rocks. They showed that fracture porosity typically ranges from $5 \times 10^{-4}$ to $5 \times 10^{-2}$ percent for clastic, metavolcanic, and crystalline rocks. This range is similar to the ranges shown in Table 3-15. At the Stripa Site in Sweden, the fracture porosity is in the range of $1 \times 10^{-3}$ to $2 \times 10^{-2}$ percent (Neretnieks et al., 1989). In the fractured basalts of eastern Washington, Gelhar (1982) measured a porosity of $4.3 \times 10^{-2}$ percent using a two-well tracer test. For carbonate rocks, the measured porosities tend to be larger. In the Culebra Dolomite of eastern New Mexico, a range of values from $2 \times 10^{-2}$ to 2 percent has been proposed (Tomasko et al., 1989).

\subsubsection{Dispersion}

Hydrodynamic dispersion of solutes in groundwater describes the macroscopic-level spreading phenomenon caused by the combined action of mechanical dispersion and molecular diffusion. Dispersion is a mixing process, the result of which causes dilution of the solute (Freeze and Cherry, 1979). The effect of dispersion is quantified and measured in terms of longitudinal and transverse dispersivities. Assessment of aquifer dispersivity is essential to predicting contaminant plume migration in groundwater. The dispersivities, both longitudinal and transverse, are key input parameters to the governing transport equation used to estimate the concentration distribution of a solute in groundwater over time and space. A summary of longitudinal, horizontal transverse, and vertical transverse dispersivity data is provided in this section.

Estimates of dispersivity may be obtained from tracer test data or through contaminant transport model calibration. Longitudinal dispersion data were obtained from the three tracer tests conducted at or near the NTS. Estimates from a model are also available in a report by Borg et al. (1976). Other estimates of dispersivity are available from the literature (Gelhar et al., 1992).

As discussed above, longitudinal dispersivities were estimated from three tracer tests conducted at the NTS and vicinity. The results are presented in Table 3-16. For the three tests listed in Table 3-16, dispersivities were calculated from the tracer data using several methods (IT, 1996e). Additional information about the tracer tests is provided in Table 3-14.

Borg et al. (1976) estimated longitudinal dispersivities from the calibration of a numerical solute transport model against hydraulic and concentration data. The longitudinal dispersivities reported by Borg et al. (1976) ranged from $11.6 \mathrm{~m}(38.1 \mathrm{ft})$ to $91 \mathrm{~m}(299 \mathrm{ft})$ for a wide variety of lithologies, 
Table 3-16

Longitudinal Dispersivity Information Summary from Tracer Tests Conducted at or near the Nevada Test Site

\begin{tabular}{|c|c|c|c|c|c|}
\hline Site Location & $\begin{array}{c}\text { Test Site } \\
\text { HSU }\end{array}$ & $\begin{array}{c}\text { Scale of } \\
\text { Test } \\
\text { meters } \\
\text { (feet) }\end{array}$ & $\begin{array}{l}\text { Analysis } \\
\text { Method }\end{array}$ & $\begin{array}{l}\text { Longitudinal } \\
\text { Dispersivity } \\
\text { meters } \\
\text { (feet) }\end{array}$ & References \\
\hline $\begin{array}{l}\text { Amargosa } \\
\text { Desert, near } \\
\text { NTS }\end{array}$ & $\begin{array}{c}\text { Fractured } \\
\text { Cambrian } \\
\text { Bonanza King } \\
\text { Dolomite } \\
(\text { LCA })\end{array}$ & $\begin{array}{l}122.8 \\
(403)\end{array}$ & $\begin{array}{l}\text { Fitting of Grove's } \\
\text { curves }\end{array}$ & $\begin{array}{c}15 \text { to } 30.5 \\
\text { (49 to } 100)\end{array}$ & $\begin{array}{l}\text { Leap \& Belmonte, } \\
1992\end{array}$ \\
\hline Yucca Flat, NTS & $\begin{array}{c}\text { Fractured } \\
\text { limestone } \\
(\text { LCA })\end{array}$ & $\begin{array}{l}29.3 \\
(96)\end{array}$ & $\begin{array}{l}\text { Calculated by } \\
\text { Welty \& Gelhar's } \\
\text { equation }\end{array}$ & $\begin{array}{c}0.6 \text { to } 1.4 \\
\text { (2.0 to } 4.6 \text { ) }\end{array}$ & $\begin{array}{l}\text { Winograd \& West, } \\
1962 \text { (calculation } \\
\text { not included) }\end{array}$ \\
\hline \multirow[t]{4}{*}{$\begin{array}{l}\text { CAMBRIC Site, } \\
\text { Frenchman Flat, } \\
\text { NTS }\end{array}$} & \multirow[t]{4}{*}{$\begin{array}{l}\text { Tuffaceous } \\
\text { alluvium } \\
\text { (AA) }\end{array}$} & \multirow[t]{4}{*}{$\begin{array}{l}91.0 \\
(299)\end{array}$} & $\begin{array}{l}\text { 1. Welty \& Gelhar } \\
\text { method }\end{array}$ & $\begin{array}{l}9.6 \\
(31)\end{array}$ & Thompson, 1991 \\
\hline & & & 2. Sauty's method & $\begin{array}{l}2.0 \\
(6.6)\end{array}$ & $\begin{array}{l}\text { Burbey \& } \\
\text { Wheatcraft, } 1986\end{array}$ \\
\hline & & & 3. Sauty's method & $\begin{array}{l}9.1 \\
(30)\end{array}$ & Travis et al., 1983 \\
\hline & & & 4. Sauty's method & $\begin{array}{c}15.1 \\
(49.5)\end{array}$ & $\begin{array}{l}\text { Thompson, } 1988 ; \\
\text { Ogard et al., } 1988\end{array}$ \\
\hline
\end{tabular}

Source: IT, 1996e

$\mathrm{HSU}=$ Hydrostratigraphic Unit

$\mathrm{AA}=$ Alluvial Aquifer

LCA = Lower Carbonate Aquifer

ranging from glacial outwash sand and gravel, to basaltic lava, to dolomite and limestone. The dispersivity for a sand and gravel deposit was estimated to be $21.3 \mathrm{~m}$ (70 ft).

The dispersivity for the Bonanza King Formation near the NTS was estimated to be $15 \mathrm{~m}$ (49 ft) (Borg et al., 1976). Their research also showed a horizontal transverse dispersivity range of 4.3 to $137 \mathrm{~m}$ (14 to $449 \mathrm{ft}$ ) (Borg et al., 1976).

Gelhar et al. (1992) performed a critical review of dispersivity observations from 59 different field sites, domestic and abroad. Gelhar et al. (1992) first evaluated the data for reliability and then analyzed the data to identify the trends. The data were classified into three reliability classes. The 
analysis indicated a trend of systematic increase of the longitudinal dispersivity with observation scale, but the trend was much less certain when the reliability of the data was considered. Gelhar et al. (1992) reported longitudinal dispersivities ranging from $10^{-2}$ to $10^{4} \mathrm{~m}\left(3 \times 10^{-2}\right.$ to $\left.3 \times 10^{4} \mathrm{ft}\right)$ for travel distances ranging from $10^{-1}$ to $10^{5} \mathrm{~m}\left(3 \times 10^{-1}\right.$ to $\left.3 \times 10^{-5} \mathrm{ft}\right)$; but the largest distance with high-reliability data was only $250 \mathrm{~m}(820 \mathrm{ft})$, and the corresponding longitudinal dispersivity was only $4 \mathrm{~m}(13 \mathrm{ft})$. Fewer data on horizontal transverse dispersivity were available. The two high-reliability points available show that horizontal transverse dispersivity is about one order of magnitude less than longitudinal dispersivity. Even fewer vertical transverse dispersivity data were available. Gelhar et al. (1992) found that in all cases where transverse dispersivities were measured, the values of vertical transverse dispersivity were one to two orders of magnitude less than those of horizontal transverse dispersivity. Gelhar et al. (1992) also concluded from the data that, overall, dispersivity values did not appear to differ with lithology (porous versus fractured media).

\subsubsection{Matrix Diffusion}

An important physical mechanism for retarding the movement of solutes in fractured rocks is matrix diffusion (Grisak et al., 1980; van Genuchten and Wierenga, 1976; Maloszewski and Zuber, 1991; Harrison et al., 1992). Diffusion into pores within the rock matrix removes the contaminants from the faster moving water in the fracture and allows additional contact with sorptive mineral surfaces. As water with dissolved contaminants flows along a fracture, a concentration gradient exists between the fracture and the water in the rock matrix immediately next to the fracture. This concentration gradient will cause contaminants to diffuse from the fracture into the matrix where they will remain for some period of time. At a later time, after the contaminant concentration front in the fracture has passed, the concentration gradient reverses, and contaminants may move back into the fracture. During the time the contaminants are in the matrix, the water in the fracture continues to move. Therefore, the mechanism of matrix diffusion slows the movement of contaminants with respect to the movement of water.

This section includes descriptions of the available matrix diffusion data for tritium compiled during the regional evaluation (IT, 1996e). A brief summary of data available for matrix diffusion of other constituents is also included. 
Available data on matrix diffusion of tritium and technetium into tuff samples from Yucca Mountain have been reported by Triay et al. (1993). A summary is presented in Table 3-17. The data summarized in Table 3-17 are limited for several reasons. First, this represents a small set of information for only one HSU. Second, the range of porosity values is narrow compared with the various rock units within Frenchman Flat. Third, these tests were performed on fresh rock surfaces, whereas most in situ fractures have some mineral coating, especially in the saturated zone. The small dataset limits the extrapolation of the results to other HSUs. This is especially true for the Lower Carbonate Aquifer, which will have characteristics that differ significantly from the tuffs at Yucca Mountain. The testing of fresh surfaces provides the most direct access for contaminants to diffuse into the rock matrix. If the fracture surface is coated with minerals, then the diffusion coefficient could be reduced. Walter (1982) conducted matrix diffusion experiments using nonsorbing organic and inorganic tracers with fractured tuff samples from the NTS (GTunnel, Area 12) and Yucca Mountain. Effective matrix diffusion coefficients ranged from $2.2 \times 10^{-7}$ to $1.7 \times 10^{-6}$ square centimeters per second $\left(\mathrm{cm}^{2} / \mathrm{s}\right)\left(2.4 \times 10^{-10}\right.$ to $1.8 \times 10^{-9}$ square feet per second $\left.\left[\mathrm{ft}^{2} / \mathrm{s}\right]\right)$. The limitations discussed above also apply to these data.

Table 3-17

Tritium and Technetium Diffusion Coefficients for the Welded Tuff Aquifer, Yucca Mountain

\begin{tabular}{||l|c|c|c|c||}
\hline \multirow{2}{*}{$\begin{array}{c}\text { Location or } \\
\text { Well }\end{array}$} & Sample & \multirow{2}{*}{$\begin{array}{c}\text { Porosity } \\
\text { (percent) }\end{array}$} & \multicolumn{2}{|c|}{$\begin{array}{c}\text { Diffusion Coefficient } \\
\left(10^{-7} \mathrm{~cm}^{2} / \mathrm{s}\right)^{\mathrm{a}}\end{array}$} \\
\cline { 4 - 6 } & & & Tritium & Technetium \\
\hline \hline USW G-4 & 737 & 7 & 22 & 3.9 \\
\hline USW GU-3 & $304 \# 1$ & 6 & 15 & 3.0 \\
\hline USW GU-3 & $304 \# 2$ & 6 & 16 & 3.0 \\
\hline USW GU-3 & 433 & 10 & 35 & $\mathrm{NA}^{\mathrm{b}}$ \\
\hline USW GU-3 & 1119 & 10 & 20 & 4.9 \\
\hline $\begin{array}{l}\text { Topopah } \\
\text { Outcrop }\end{array}$ & $\mathrm{NA}$ & 7 & 10 & 1.0 \\
\hline
\end{tabular}

Source: Triay et al., 1993

\footnotetext{
${ }^{\text {a }}$ Square centimeters per second

${ }^{\mathrm{b}}$ Not available
} 
The remainder of this section presents selected matrix diffusion data from the literature.

Harrison et al. (1992) modeled diffusion of organic contaminants into clay till in Canada. They used effective diffusion coefficient values in the range of $1.5 \times 10^{-6} \mathrm{~cm}^{2} / \mathrm{s}\left(1.6 \times 10^{-9} \mathrm{ft}^{2} / \mathrm{s}\right)$. In modeling diffusion of strontium and plutonium in fractured granite, Krishnamoorthy et al. (1992) chose a range of values from $4.8 \times 10^{-7}$ to $1.9 \times 10^{-6} \mathrm{~cm}^{2} / \mathrm{s}\left(5.2 \times 10^{-10}\right.$ to $\left.2.1 \times 10^{-9} \mathrm{ft}^{2} / \mathrm{s}\right)$. Feenstra et al. (1984) measured diffusion through intact sandstone cores and obtained a range of values from $3.4 \times 10^{-8}$ to $3.2 \times 10^{-7} \mathrm{~cm}^{2} / \mathrm{s}\left(3.7 \times 10^{-11}\right.$ to $\left.3.4 \times 10^{-10} \mathrm{ft}^{2} / \mathrm{s}\right)$ with a mean of $1.5 \times 10^{-7} \mathrm{~cm}^{2} / \mathrm{s}\left(1.6 \times 10^{-10} \mathrm{ft}^{2} / \mathrm{s}\right)$. In mudstone, Barone et al. (1992) measured a diffusion coefficient of $1.5 \times 10^{-6}$ to $2.0 \times 10^{-6} \mathrm{~cm}^{2} / \mathrm{s}$ $\left(1.6 \times 10^{-9}\right.$ to $\left.2.2 \times 10^{-9} \mathrm{ft}^{2} / \mathrm{s}\right)$. In their study, Hadermann and Heer (1996) obtained matrix diffusion coefficients of $2.5 \times 10^{-7} \mathrm{~cm}^{2} / \mathrm{s}\left(2.7 \times 10^{-10} \mathrm{ft}^{2} / \mathrm{s}\right)$.

\subsubsection{Distribution Coefficients}

The distribution coefficient $\left(\mathrm{K}_{\mathrm{d}}\right)$ is a factor that is used in transport modeling to account for a variety of chemical interactions between dissolved contaminants and the solid substrate through which the contaminants are transported. Measured $\mathrm{K}_{\mathrm{d}}$ values are typically a function of the chemistry of the solid substrate, the composition of the water, and a variety of experimental variables including water to rock ratio, batch versus column testing, and particle size of solid substrate. In some cases measured $K_{d}$ values may reflect processes other than sorption, e.g., precipitation (Meijer, 1990).

Table 3-18 lists $\mathrm{K}_{\mathrm{d}}$ values as reported by studies of the NTS and Yucca Mountain Project for selected contaminants that may be of concern to the Frenchman Flat CAU. The wide range of $\mathrm{K}_{\mathrm{d}}$ values shown in Table 3-18 is indicative of the site-specific nature of contaminant retardation during subsurface migration. The $\mathrm{K}_{\mathrm{d}}$ values in Table 3-18 from Triay et al. (1997) are the data recommended for use in the Yucca Mountain performance assessment. The $\mathrm{K}_{\mathrm{d}}$ ranges shown are based on data obtained from studies using both volcanic and carbonate aquifer groundwater. For most of the elements listed in Table 3-18, Triay et al. (1997) reported $\mathrm{K}_{\mathrm{d}}$ ranges for an iron-oxide substrate and devitrified, vitrified, and zeolitic tuff. For carbon, $\mathrm{K}_{\mathrm{d}}$ data were only available for the iron-oxide substrate.

The $\mathrm{K}_{\mathrm{d}}$ ranges reported by Meijer (1990) are from Yucca Mountain Project batch sorption experiments on crushed tuff samples (Table 3-18). The composition of groundwater from NTS Well J-13, a Na-K-HCO 3 water type (Section 3.4.6), was used as the reference composition for most 
of the sorption experiments. Distribution coefficient data reported by Meijer (1990) for experiments that used very fine particles (less than 500-micrometer diameter) were omitted from Table 3-18. This is because the $\mathrm{K}_{\mathrm{d}}$ values derived from tests with very fine material can be unrealistically large.

Table 3-18 also contains $\mathrm{K}_{\mathrm{d}}$ data from Borg et al. (1976). Except for tests performed using alluvium, which were from the Central Nevada Test Area, all solids used in the $\mathrm{K}_{\mathrm{d}}$ studies were from the NTS.

Table 3-18

Summary of Distribution Coefficient Data

\begin{tabular}{|c|c|c|c|c|c|}
\hline \multirow{3}{*}{$\begin{array}{l}\text { Constituent } \\
\text { Carbon }\end{array}$} & \multicolumn{5}{|c|}{ Distribution Coefficient (milliliters per gram) } \\
\hline & \multicolumn{2}{|c|}{ Triay et al. (1997) } & \multirow{2}{*}{$\frac{\text { Meijer (1990) }}{\text { ND }}$} & \multicolumn{2}{|c|}{ Borg et al. (1976) } \\
\hline & iron oxide: & $10-100$ & & & \\
\hline Cesium & $\begin{array}{l}\text { devitrified tuff: } \\
\text { vitric tuff: } \\
\text { zeolitic tuff: } \\
\text { iron oxide: }\end{array}$ & $\begin{array}{r}20-1,000 \\
10-100 \\
500-5,000 \\
0-500\end{array}$ & $123-39,000$ & $\begin{array}{l}\text { alluvium: } \\
\text { tuff: } \\
\text { carbonate: }\end{array}$ & $\begin{array}{r}120-3,170 \\
1,020-17,800 \\
14\end{array}$ \\
\hline lodine & & & ND & tuff: & 1 \\
\hline Lead & $\begin{array}{l}\text { devitrified tuff: } \\
\text { vitric tuff: } \\
\text { zeolitic tuff: } \\
\text { iron oxide: }\end{array}$ & $\begin{array}{r}100-500 \\
100-500 \\
100-500 \\
100-1,000\end{array}$ & ND & & \\
\hline Plutonium & $\begin{array}{l}\text { devitrified tuff: } \\
\text { vitric tuff: } \\
\text { zeolitic tuff: } \\
\text { iron oxide: }\end{array}$ & $\begin{array}{r}50-300 \\
50-300 \\
30-300 \\
1,000-5,000\end{array}$ & $64-4,700$ & & \\
\hline Strontium & $\begin{array}{l}\text { devitrified tuff: } \\
\text { vitric tuff: } \\
\text { zeolitic tuff: } \\
\text { iron oxide: }\end{array}$ & $\begin{array}{r}10-200 \\
20-50 \\
2,000-50,000 \\
0-30\end{array}$ & $22-87,000$ & $\begin{array}{l}\text { alluvium: } \\
\text { tuff: } \\
\text { carbonate: }\end{array}$ & $\begin{array}{r}50-2,45 c \\
260-4,30 c \\
0.2\end{array}$ \\
\hline Uranium & $\begin{array}{l}\text { devitrified tuff: } \\
\text { vitric tuff: } \\
\text { zeolitic tuff: } \\
\text { iron oxide: }\end{array}$ & $\begin{array}{r}0-5.0 \\
0-4.0 \\
5-20.0 \\
100-1,000\end{array}$ & $0-54$ & & \\
\hline
\end{tabular}

$\mathrm{ND}=$ No data 
Although $\mathrm{K}_{\mathrm{d}}$ values may vary by orders of magnitude for a given contaminant, several general observations can be made based on the data presented in Table 3-18. These observations are:

- Iodine does not sorb.

- Carbon and uranium are not greatly sorbed.

- Cesium, lead, plutonium, and strontium sorption is appreciable, regardless of substrate.

- Cesium and strontium sorption is very high in zeolitic tuff.

The observation that cesium and strontium sorption appears to be increased in zeolitized units, while lead and plutonium sorption is not, is probably due to differences in the sorption mechanisms of these constituents. Cesium and strontium probably are influenced by cation exchange in zeolitic tuffs.

\subsubsection{Colloidal Transport}

Colloids are small, less than $1 \mu \mathrm{m}$, particles that may facilitate the migration of contaminants in the groundwater flow system. Dissolved contaminants may be removed from solution and attached to colloids by ion exchange or adsorption. Ramsay (1988) described three general cases for colloidal-facilitated contaminant migration: (1) uncharged colloid particles that migrate without retardation; (2) charged colloids that have the same sign as the surface charge of the aquifer medium and are repelled by the medium walls, resulting in a net increase in colloid flow velocity; and (3) colloids and the medium surfaces that have opposite charges, which could result in a slowing down of the colloid particles by interaction with the medium. Colloids are comprised of either organic material or inorganic mineral fragments and secondary minerals of the host rock. Oxides and hydroxides of actinide elements (e.g., plutonium) can also form as colloids (Smith et al., 1998).

Bryant (1992b) reported that the CAMBRIC RNM Project included several exploratory colloid experiments. These experiments indicated the presence of a substantial particle concentration at Well RNM-1 and a small concentration at Well RNM-2S. Particles at RNM-1 include clay (possibly from drilling mud) and amorphous materials. At RNM-2S, calcite was identified as a major constituent (Bryant, 1992b). However, it must be noted that calcite can precipitate from solution in a sample that is subjected to changing physical conditions.

Colloids containing radionuclides have also been observed in groundwater at Pahute Mesa. The mass concentration of colloids in groundwater from the CHESHIRE test location (Area 20) was $10 \mathrm{mg} / \mathrm{L}$ in 
a sample from the cavity region and $4 \mathrm{mg} / \mathrm{L}$ in a sample from the formation above the cavity (Buddemeier, 1988). The fraction of total radioactivity associated with colloids varied by radionuclide; some radionuclides were present in groundwater entirely as dissolved species (e.g., tritium), while others were predominantly associated with colloids (e.g., europium).

Kingston and Whitbeck (1991) characterized colloids found in water from springs and wells in central and southern Nevada. The majority of the sites are on or within $50 \mathrm{~km}(31 \mathrm{mi})$ of the NTS. Kingston and Whitbeck reported that most groundwater studied had concentrations ranging from 0.28 to $1.35 \mathrm{mg} / \mathrm{L}$ for colloids in the 0.03 to $1.0 \mu \mathrm{m}$ diameter range. The mean concentration based on all data was $0.9 \mathrm{mg} / \mathrm{L}$ and was $0.58 \mathrm{mg} / \mathrm{L}$ for NTS locations only. The colloid concentration was similar regardless of hydrologic setting, aquifer lithology, or geographic location. Kingston and Whitbeck (1991) concluded that, based on their ubiquitous occurrence, colloids successfully travel through the subsurface on the NTS, and similar concentrations among the various size fractions may be indicative of groundwater flow at the NTS being controlled by faults and fractures. The later conclusion is apparently based on the assumption that flow through a porous matrix (as opposed to through faults and fractures) will result in filtration (removal) of a specific colloid size fraction from groundwater.

Additional information on the nature and behavior of colloids in groundwater at the NTS and the Yucca Mountain region are presented in Buddemeier and Hunt (1988), Kingston and Whitbeck (1991), Thompson (1998), and Triay et al. (1997). Other colloid research and modeling activities potentially applicable to the Frenchman Flat CAU include Grindrod and Lee (1997), Mills et al. (1991), Penrose et al. (1990), Puls et al. (1991), Toran and Palumbo (1992), and Vilks et al. (1997).

\subsection{Contaminants}

Based on the process knowledge, this section includes descriptions of all known and/or inferred radioactive and hazardous substances present in the Frenchman Flat CAU. In addition, also included is a description of those substances that are considered potential contaminants based on the risks they may pose to human health and the environment. 


\subsubsection{Radioactive and Hazardous Substances Present}

The three predominant types of substances associated with the radiologic source term are: (1) in situ material or those contained within the device that have not undergone fission or thermonuclear reaction; (2) direct products of the nuclear reactions, such as fission products; and (3) radionuclides produced by activation of the fuel, materials used within the test, and the surrounding environment affected by the test.

Table 3-19 lists materials commonly used in or produced as a result of an underground nuclear test. During a given underground nuclear test, large quantities of materials used to support the test were introduced into the shafts or tunnels. These materials included steel used to support the device, lead and magnetite used as shielding material, and cement and gravel used to backfill the opening. In addition, nuclear devices commonly contained fissionable or fusionable radioactive elements in the critical mass for detonation. These elements include uranium, plutonium, tritium, and lithium. Small amounts of radiochemical detectors were also used. Incomplete consumption of these radioactive materials during detonation from testing would leave them within the subsurface for potential leaching to groundwater (Bryant and Fabryka-Martin, 1991).

\subsubsection{Potential Contaminants for the CAI}

The potential contaminants for the Frenchman Flat CAI are defined as that set of contaminants that would cause risk to human health and the environment within the 1,000-year time frame. A systematic approach was used to select the potential contaminants for the CAI.

A comprehensive list of radiological contaminants was established based on knowledge of radionuclides that are residual from underground nuclear testing. The list, shown in Table 3-20, includes 64 radiological contaminants (Smith, 1995a). Fifty-six of the candidate contaminants are naturally occurring and nuclear weapon-produced radionuclides with half-lives greater than ten years. The other eight candidate contaminants are radionuclides with half-lives of less than ten years. These eight radionuclides were added to the comprehensive list because they are presently encountered in fluids returned from saturated nuclear test cavities (Smith, 1997). The comprehensive list (Table 3-20) was used to derive a preliminary list of potential contaminants (Table 3-21) that are relevant to UGTA corrective action activities (Smith, 1997). 
Table 3-19

Materials Involved in Underground Nuclear Testing

\begin{tabular}{|c|c|c|c|}
\hline $\begin{array}{c}\text { Fuels, Detectors, } \\
\text { Tracers }\end{array}$ & $\begin{array}{c}\text { Rack/Canister } \\
\text { Materials }\end{array}$ & Organics & $\begin{array}{c}\text { Drilling/Stemming } \\
\text { Materials }\end{array}$ \\
\hline $\begin{array}{l}\text { Americium } \\
\text { Curium } \\
\text { Neptunium } \\
\text { Plutonium } \\
\text { Tritium } \\
\text { Uranium } \\
\text { Lithium } \\
\text { Yttrium } \\
\text { Zirconium } \\
\text { Thulium } \\
\text { Lutetium }\end{array}$ & $\begin{array}{l}\text { Aluminum } \\
\text { Arsenic } \\
\text { Barite } \\
\text { Beryllium } \\
\text { Boron } \\
\text { Cadmium } \\
\text { Chrome Lignosulfate } \\
\text { Chromium } \\
\text { Copper } \\
\text { Gold } \\
\text { Iron } \\
\text { Lead } \\
\text { Lithium }^{\text {Magnetite }}{ }^{d} \\
\text { Nickel } \\
\text { Osmium } \\
\text { Potassium Chloride } \\
\text { Sodium Hydroxide } \\
\text { Tantalum } \\
\text { Tungsten } \\
\text { Zinc }\end{array}$ & $\begin{array}{l}\text { Alcohol } \\
\text { Anionic Polyacrylamide } \\
\text { Coal-Tar Epoxy } \\
\text { Complex Fluorescing Compounds } \\
\text { Galacto-Mannans }\left(\mathrm{C}_{6} \mathrm{H}_{10} \mathrm{O}_{5}\right)_{n} \\
\text { Laser Dyes }^{a} \\
\text { Liquid Anionic Polyelectrolyte } \\
\text { Paraformaldehyde } \\
\text { Phenolic } \\
\text { Polystyrene } \\
\text { Polyvinyl Chloride } \\
\text { Two-Part Epoxy }\end{array}$ & $\begin{array}{l}\text { Bentonite } \\
\text { Cement } \\
\text { Gel } \\
\text { Gravel } \\
\text { Modified Starch }^{\text {Neoprene }}{ }^{\circledR} \\
\text { Polyethylene } \\
\text { Pregelatinized Starch } \\
\text { Sand } \\
\text { Sepiolite } \\
\text { Soda Ash } \\
\text { Sodium Polyacrylate } \\
\text { Sodium Montmorillonite }^{\text {Surfactant TF Foamer }} \\
\text { Surlon }^{\mathrm{TM}}\end{array}$ \\
\hline
\end{tabular}

Source: Bryant and Fabryka-Martin (1991)

${ }^{a}$ Fluorescing compounds and laser dyes used in some detector packages may contain potentially hazardous organic constituents.

${ }^{b}$ Contains theophylline, ethylenediamine, carbonic acid disodium salt

${ }^{\mathrm{C}}$ Extensive quantities of lead (57.2 metric tons) are typically used as shielding material for device canisters and racks.

${ }^{d}$ Magnetite is naturally occurring $\mathrm{Fe}_{3} \mathrm{O}_{4}$ containing thorium and other heavy rare earths.

Three criteria were used in formulating the preliminary list of potential radioactive contaminants shown in Table 3-21: (1) the production of the radionuclide in a nuclear test, (2) the relative mobility of the radionuclide determined from historical field observations, and (3) the health effect of the radionuclide relative to a total body or organ dose. The health effects were obtained from a ranking of radionuclides related to DOE and proposed EPA drinking water standards.

The preliminary list reflects an evaluation of each of the 64 candidate radionuclides against the above criteria. This list (Table 3-21) represents radionuclides potentially of concern at sites contaminated by underground nuclear testing. 
Table 3-20

Comprehensive List of Radionuclides Related to Underground Testing

\begin{tabular}{|c|c|c|c|c|c|c|c|}
\hline \multicolumn{8}{|c|}{ Radionuclides } \\
\hline Aluminum-26 & Carbon-14 & Europium-152 & Krypton-85 & Niobium-92g & Plutonium-241 & Sodium-22 ${ }^{\mathrm{a}}$ & Uranium-232 \\
\hline Americium-241 & Cesium-134 & Europium-154 & Lead-205 & Niobium-93m & Plutonium-242 & Strontium-90 & Uranium-233 \\
\hline Americium-243 & Cesium-135 & Europium-155 & Lead-210 & Niobium-94 & Protactinium-231 & Technetium-98 & Uranium-234 \\
\hline Antimony-125 & Cesium-137 & Hafnium-178m & Manganese-53 & Palladium-107 & Rhenium-186m & Technetium-99g & Uranium-235 \\
\hline Argon-39 & Chlorine-36 & Holmium-166m & Molybdenum-93 & Platinum-193 & Ruthenium-106 & Thorium-232 & Uranium-236 \\
\hline Beryllium-10 & Cobalt- $60^{\mathrm{a}}$ & lodine-129 & Neptunium-237 & Plutonium-238 & Samarium-146 & Tin-121m & Uranium-238 \\
\hline Cadmium-113m & Curium-244 & Iridium-192m & Nickel-59 & Plutonium-239 & Samarium-151 & Tin-126 & Zinc- $65^{\mathrm{a}}$ \\
\hline Calcium-41 & Europium-150 & Krypton-81 & Nickel-63 & Plutonium-240 & Selenium-79 & Tritium & Zirconium-93 \\
\hline
\end{tabular}

Source: Smith, 1995a

${ }^{\mathrm{a}}$ Short-lived radionuclide, half-life less than ten years. 
Table 3-21

Preliminary List of Potential Contaminants for UGTA

\begin{tabular}{|c|c|c|c|}
\hline Contaminant of Concern & Abbreviation & Half-Life (years) & Criteria \\
\hline Americium-241 & $A m-241$ & 432.7 & health \\
\hline Antimony-125 & $\mathrm{Sb}-125$ & 2.758 & mobility \\
\hline Carbon-14 & C-14 & 5,730 & mobility, health \\
\hline Cesium-134 & Cs-134 & 2.065 & health \\
\hline Cesium-137 & Cs-137 & 30.17 & production, health \\
\hline Chlorine-36 & $\mathrm{Cl}-36$ & $3.01 \times 10^{5}$ & mobility \\
\hline Cobalt-60 & Co-60 & 5.27 & mobility \\
\hline Europium-152 & Eu-152 & 13.48 & production \\
\hline Europium-154 & Eu-154 & 8.59 & production \\
\hline Europium-155 & Eu-155 & 4.74 & production \\
\hline lodine-129 & $\mathrm{I}-129$ & $1.57 \times 10^{7}$ & mobility, health \\
\hline Krypton-85 & $\mathrm{Kr}-85$ & 10.73 & mobility \\
\hline Neptunium-237 & $\mathrm{Np}-237$ & $2.14 \times 10^{6}$ & mobility, health \\
\hline Plutonium-239 & Pu-239 & $2.41 \times 10^{4}$ & production, health \\
\hline Plutonium-240 & Pu-240 & $6.56 \times 10^{3}$ & production, health \\
\hline Ruthenium-106 & Ru-106 & 1.02 & mobility \\
\hline Samarium-151 & Sm-151 & 90 & production \\
\hline Strontium-90 & Sr-90 & 29.1 & production, health \\
\hline Technetium-99 & Tc-99 & $2.13 \times 10^{5}$ & mobility \\
\hline Tritium & $\mathrm{H}-3$ & 12.3 & production, mobility \\
\hline Uranium-234 & $U-234$ & $2.46 \times 10^{5}$ & production, health \\
\hline Uranium-238 & U-238 & $4.47 \times 10^{9}$ & production, health \\
\hline
\end{tabular}

Source: Smith, 1997

Note: This table does not contain any classified data. 
A list of potential contaminants for the 1,000-year CAI time period was derived by the UGTA Technical Working Group from the preliminary list presented in Table 3-21. Seven radioactive contaminants: ${ }^{14} \mathrm{C},{ }^{129} \mathrm{I},{ }^{239 / 240} \mathrm{Pu},{ }^{137} \mathrm{Cs},{ }^{90} \mathrm{Sr}$, tritium, and uranium-238 $\left({ }^{238} \mathrm{U}\right)$ were selected based on observed concentrations in groundwater, inventory estimates, health effects, and fate and transport information. These radionuclides were considered to be the most significant for prediction of the contaminant boundary over a 1,000-year time period. The seven radionuclides were included in the modeling performed for the Frenchman Flat VOIA (IT, 1997c).

In addition to the seven radionuclides discussed above, other radioactive contaminants listed in Table 3-21 may be of potential concern to the Frenchman Flat CAU. The list of potential radioactive contaminants that will be included in simulations of the contaminant boundary for Frenchman Flat may be modified based on the findings of the CAI.

Lead is also considered a potential contaminant for the Frenchman Flat CAU because it is known to have been used in significant quantities in underground nuclear tests (Table 3-19). In addition, lead represents a RCRA contaminant. It was assumed that any volatile or semivolatile organic RCRA constituent would be consumed during the explosion; therefore, only metals could remain as potential contaminants.

Table 3-22 is a list of observed maximum concentrations for the seven potential radioactive contaminants evaluated in the Frenchman Flat VOIA (IT, 1997c). The concentrations were obtained from the analysis of fluid samples collected from underground test cavities or areas immediately adjacent to test cavities. Most of the data are from the CAMBRIC test location in Frenchman Flat; however, for some radionuclides the concentration data are from test locations outside of Frenchman Flat because data were not available from CAMBRIC (Table 3-22).

\subsection{Conceptual Model of the CAU}

This section contains a discussion of the conceptual model of the Frenchman Flat CAU. Included in the description is an overview of the conceptual model, followed by detailed descriptions of the release and discharge mechanisms, migration routes, contaminated media, and exposure pathways associated with the underground nuclear testing. The conceptual model for Frenchman Flat is 
Table 3-22

Maximum Observed Concentrations of Potential Radioactive Contaminants in Frenchman Flat Nuclear Test Cavity Groundwater

\begin{tabular}{|c|c|c|c|}
\hline $\begin{array}{c}\text { Potential } \\
\text { Contaminant }\end{array}$ & $\begin{array}{c}\text { Concentration } \\
(\mathrm{pCi} / \mathrm{L})\end{array}$ & Sampling Location & Source \\
\hline \hline Carbon-14 & $6.1 \mathrm{E}+04$ & Area 20, Pahute Mesa (CHESHIRE) & Smith et al. (1996) \\
\hline Cesium-137 & $5.6 \mathrm{E}+03$ & Area 5, Frenchman Flat (CAMBRIC) & Hoffman et al. (1977) \\
\hline lodine-129 & $1.1 \mathrm{E}+01$ & Area 5, Frenchman Flat (CAMBRIC) & Daniels (1993) \\
\hline Plutonium-239/240 & $6.3 \mathrm{E}+00^{\text {b }}$ & Area 5, Frenchman Flat (CAMBRIC) & Hoffman et al. (1977) \\
\hline Strontium-90 & $4.0 \mathrm{E}+03$ & Area 5, Frenchman Flat (CAMBRIC) & Hoffman et al. (1977) \\
\hline Tritium & $7.7 \mathrm{E}+09$ & Area 5, Frenchman Flat (CAMBRIC) & Hoffman et al. (1977) \\
\hline Uranium-238 & $2.7 \mathrm{E}+01$ & Area 3, Yucca Flat (BILBY) & Daniels (1993) \\
\hline
\end{tabular}

${ }^{\mathrm{a}}$ Concentration at the time of collection.

${ }^{\mathrm{b}}$ Concentration of plutonium-239.

$\mathrm{pCi} / \mathrm{L}=$ Picocurie(s) per liter

adapted from the regional model (DOE/NV, 1997) and additional modeling calculations provided in the Frenchman Flat VOIA (IT, 1997c).

\subsubsection{Overview of Conceptual Model}

Ten underground nuclear tests were detonated in Frenchman Flat between 1965 and 1971. Media contaminated by the underground nuclear tests of Frenchman Flat are subsurface soils within the unsaturated and saturated zones. Groundwater transport is the primary means of migration for the subsurface contamination away from the Frenchman Flat underground nuclear tests. An overview of the conceptual model of groundwater flow and contaminant transport in Frenchman Flat is provided in this section. This conceptual model is adapted from the regional model (DOE/NV, 1997) and the Frenchman Flat VOIA (IT, 1997c).

\section{Groundwater Flow System}

This overview of the groundwater flow system of Frenchman Flat includes a brief description of the geology and hydrogeology. Detailed descriptions are provided in Section 3.4.4.2 (Site Geology) and Section 3.4.5.2 (Hydrogeology of the Investigation Area). 
Frenchman Flat, a typical basin within the Basin and Range Province, consists of Precambrian, Paleozoic, Tertiary and Quaternary geologic units. The basin was formed by down-dropping of the Tertiary and Paleozoic units along a series of interpreted northeast-striking normal faults. The faults are thought to have tilted the strata toward the east in several fault blocks. The basin is underlain by up to $3,000 \mathrm{~m}(9,840 \mathrm{ft})$ of Paleozoic carbonate rocks. The carbonate section is overlain in the northern and western parts of the basin by Tertiary volcanic tuffs. These tuffs originated from volcanoes to the west and northwest on the Nevada Test Site. These tuffs are exposed around the northern and western edges of Frenchman Flat and are thickest in these two areas. The tuffs are thought to overlay much of the Paleozoic rock in the subsurface, but they pinch out toward the southeast.

Younger Tertiary sedimentary rocks crop out on the eastern and western margins of the basin and are, therefore, inferred to be present in the basin on top of the volcanic units. However, there may be locations in the basin where volcanic tuffs and Tertiary sedimentary rocks are not present. The basin has filled with Quaternary and Tertiary alluvium covering the faults and the strata. The alluvium consists mostly of sands and silts, and is as thick as 1,400 $\mathrm{m}(4,600 \mathrm{ft})$ in the center of the basin, according to geophysical interpretations.

As described in Section 3.4.5.2.2, the hydrostratigraphy of Frenchman Flat consists of several aquifers and confining units. The major aquifers include the Alluvial Aquifer, the Volcanic Aquifer and the Lower Carbonate Aquifer. The existing hydraulic conductivity data show that in general, the most transmissive aquifer is the Lower Carbonate Aquifer, followed by the Alluvial Aquifer and finally the Volcanic Aquifer. Hydraulic conductivity ranges for these aquifers based on the existing site-specific data are provided in Table 3-8 of this document. The hydraulic conductivity of the Alluvial Aquifer ranges between 0.048 and $25 \mathrm{~m} / \mathrm{d}(0.158$ and $82 \mathrm{ft} / \mathrm{d})$, based on data from eight wells. The hydraulic conductivity of the Lower Carbonate Aquifer ranges between 0.009 and $228 \mathrm{~m} / \mathrm{d}(0.029$ and $748 \mathrm{ft} / \mathrm{d})$, based on data from three wells. Based on information from one well only, the hydraulic conductivity of the Volcanic Aquifer ranges between 1.04 and $1.38 \mathrm{~m} / \mathrm{d}(3.41$ and $4.53 \mathrm{ft} / \mathrm{d})$.

Groundwater flow within Frenchman Flat is part of the NTS flow system, which is part of the Death Valley flow system. Most groundwater flowing through Frenchman Flat passes through the Lower 
Carbonate Aquifer, a regional aquifer with no physical lateral hydrologic boundaries. The Frenchman Flat groundwater flow system includes several major aquifers and confining units (Figure 3-13). The Lower Clastic Confining Unit forms the basement of the flow system. Overlying the Lower Clastic Confining Unit is the Lower Carbonate Aquifer, a major regional aquifer. The Lower Carbonate Aquifer is overlain by the Volcanic Confining Unit and the Volcanic Aquifer. The Alluvial Aquifer overlies the volcanic units. The water table is shallow enough in Frenchman Flat to saturate the Tertiary and Quaternary geologic units. Water levels measured in the alluvium (Figure 3-7) indicate that the water surface is almost flat. Although the horizontal hydraulic gradients within the Frenchman Flat aquifer system are small (Figure 3-8), the regional groundwater flow directions are clearly from the north and east to the southwest (Figure 3-13). As postulated by Winograd and Thordarson (1975) and by Laczniak et al. (1996), a potential for vertical groundwater movement to the Lower Carbonate Aquifer exists. Groundwater would drain from the Alluvial Aquifer and Volcanic Aquifer into the Lower Carbonate Aquifer either by vertical leakage, or through a local sink. However, such leakage is believed to be too small to cause contaminant migration from the Alluvial Aquifer and the Volcanic Aquifer into the Lower Carbonate Aquifer.

Groundwater recharge to the Frenchman Flat flow system occurs mostly through the subsurface. Groundwater enters Frenchman Flat by subsurface inflow through the Lower Carbonate Aquifer, from Yucca Flat (to the north) and Indian Spring Valley (to the east) A minor amount of areal recharge to the Alluvial Aquifer occurs within the Frenchman Flat basin as a result of precipitation (Table 7.4 on page 7-14 in IT, 1996b). Areas of areal recharge located within the area of interest are shown in Figure 3-13. No surface discharge from the regional flow system occurs within the Frenchman Flat basin. Groundwater leaves the Frenchman Flat groundwater flow system from the southwest and flows towards Mercury Valley. Groundwater pumping in the area is limited and is not believed to affect flow in Frenchman Flat.

Particle tracking simulations were performed during the regional evaluation (DOE/NV, 1997) and the VOIA (IT, 1997c). These simulations were used to identify the pathlines that imaginary particles follow from given nuclear test locations through the flow model. Pathlines help define flow directions and potential migration pathways. The particle tracking results, Figure 7-26 in the regional evaluation report (DOE/NV, 1997) and Figure 2-1 in the VOIA report (IT, 1997c), show that pathlines flowing through the Frenchman Flat test locations follow the general direction of flow, 


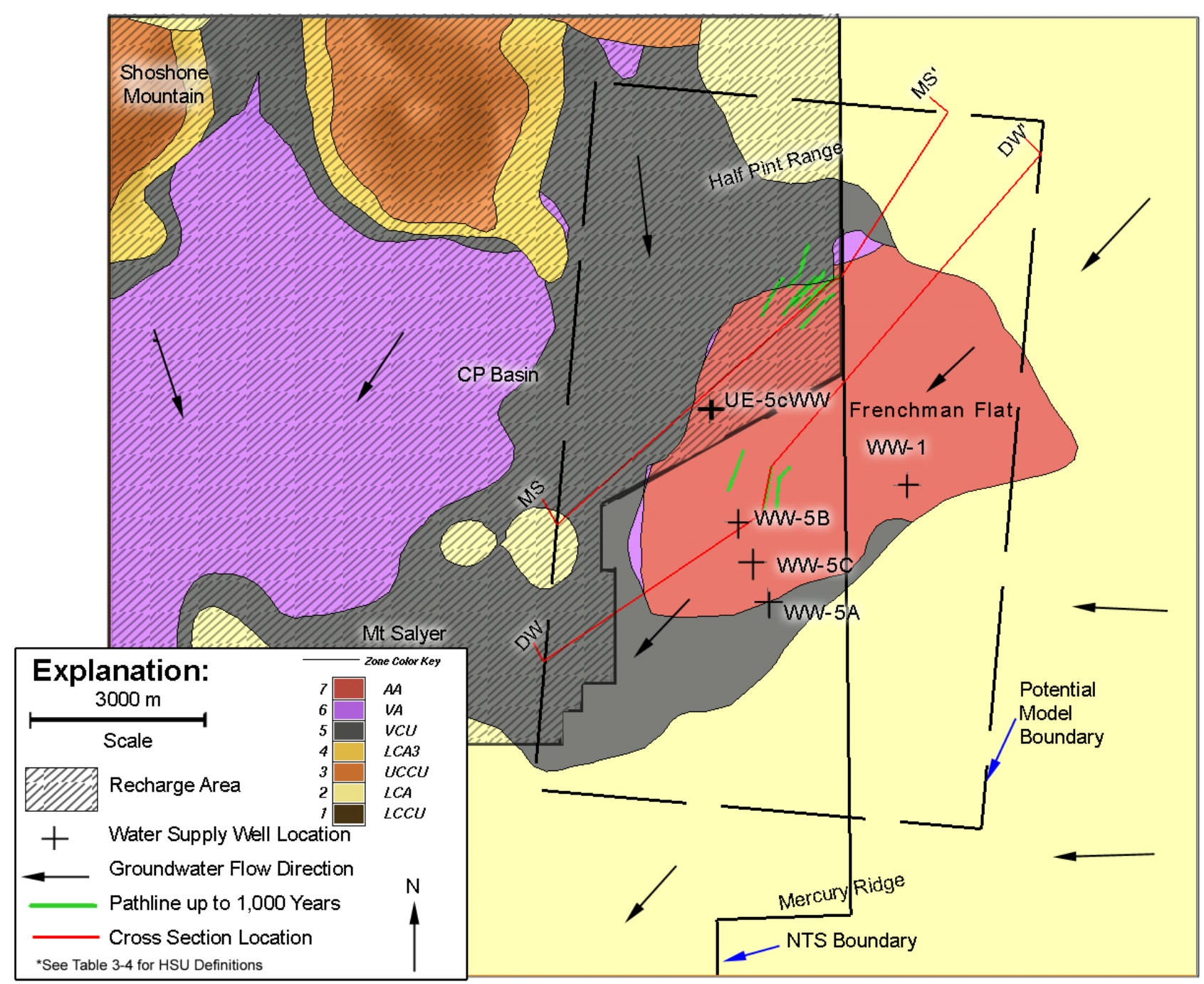

Figure 3-13

Plan View of Frenchman Flat Conceptual Model

(Groundwater pathlines are superposed on plan view of hydrostratigraphic model at water table.) 
southwest, across the Frenchman Flat area. The pathlines would indicate that groundwater ultimately discharges in the Amargosa River discharge area, located southwest of Frenchman Flat.

\section{Contaminant Transport}

This overview of contaminant transport in Frenchman Flat includes summary descriptions of the sources of contamination, the release mechanisms to groundwater, migration routes, contaminant transport processes, and simulated extent of contamination.

Each of the underground nuclear tests resulted in a test cavity, rubble chimney and a disturbed area extending beyond the cavity by approximately one cavity radius. The saturated portion of the test cavity, rubble chimney, and disturbed area forms the volume of the contamination source created by a given underground nuclear test. All Frenchman Flat underground nuclear tests were detonated in the alluvial and volcanic rocks, which overlie the Lower Carbonate Aquifer. The depths of these tests were either below or within $100 \mathrm{~m}(328 \mathrm{ft})$ of the water table in the alluvial and volcanic material. Potential contaminants include radionuclides used and/or created during the nuclear test, and possibly other hazardous constituents used in the tests. A detailed description of the contaminants present in the subsurface of Frenchman Flat is presented in Section 3.5 of this document.

During the nuclear tests, contaminants may have been promptly injected into the subsurface materials surrounding the nuclear device. However, evidence indicates only a very limited amount of prompt injection occurred. Following the nuclear test, the cavity refills with groundwater and contaminant release into groundwater is initiated. No site-specific information on contaminant release processes exists. However, based on general information about underground nuclear tests, the processes by which contaminant are released into groundwater include leaching and ion exchange (Borg et al., 1976). Contaminants may leach from the melt glass, the rubble chimneys, or the fracture surfaces and pore spaces adjacent to the test cavities. Ion exchange processes may also release contaminants that are bound to minerals of the rubble after groundwater refills the rubble chimney.

The migration behavior of a given contaminant within a given flow system is dictated by several transport processes, which determine migration distances and concentrations. Major contaminant transport processes of interest to Frenchman Flat include advection, dispersion, sorption, matrix diffusion and radioactive decay. Available information on transport parameters is provided in 
Section 3.4.8 of this document. Two underground nuclear test were selected for contaminant transport simulations during the VOIA (IT, 1997c). The DILUTED WATERS nuclear test was used to represent contaminant sources in Area 5 and the MINUTE STEAK nuclear test was selected to represent contaminant sources in Area 11. However, because the two pathlines are very similar, base-case transport simulations were performed only along the DILUTED WATERS pathline. The results of these simulations are presented in Figure 2-2 through Figure 2-6 of the Frenchman Flat VOIA (IT, 1997c). The distances of the $4 \mathrm{mrem} / \mathrm{yr}$ dose at 95 percent confidence within 1,000 years from the test locations were derived from these results and plotted on Cross-Section DW-DW' (Figure 3-14) and Cross-Section MS-MS' (Figure 3-15). The locations of the cross-sections are shown in Figure 3-13. The VOIA results (IT, 1997c) were further extrapolated to all other tests to estimate the maximum distance from the source of the $4 \mathrm{mrem} / \mathrm{yr}$ dose within a 1,000-year period. The estimated distance is approximately $1,500 \mathrm{~m}$ at the 95 percent confidence level. These distances are depicted in Figure 3-13, which also shows the locations of the water supply wells. The contamination is not expected to affect the water supply wells within the 1,000-year period.

\subsubsection{Release and Discharge Mechanisms}

The release mechanisms of contaminants from underground nuclear tests to the subsurface, including groundwater, are described in this section. A brief description of potential contaminant discharge to the environment from Frenchman Flat, via groundwater, is also included.

\subsubsection{Release Mechanisms}

Nonnaturally occurring radionuclides and other contaminants enter the groundwater system through a variety of mechanisms starting with the explosion of the nuclear device. Figure 3-16 is a schematic diagram of the processes whereby radionuclides can enter the groundwater flow system as a result of underground nuclear testing.

To support the understanding of release mechanisms associated with underground nuclear tests, this section includes a generalized description of nuclear explosion phenomenology from Pawloski (1998). Phenomenology describes the effects of the nuclear explosion on the surrounding medium. Actions that occur during the time period from the explosion to when the cavity void grows to its full size and then rebounds are referred to as early time phenomena. Actions that occur after the cavity has reached its full size are referred to as late time phenomena and consist mainly of thermally induced 


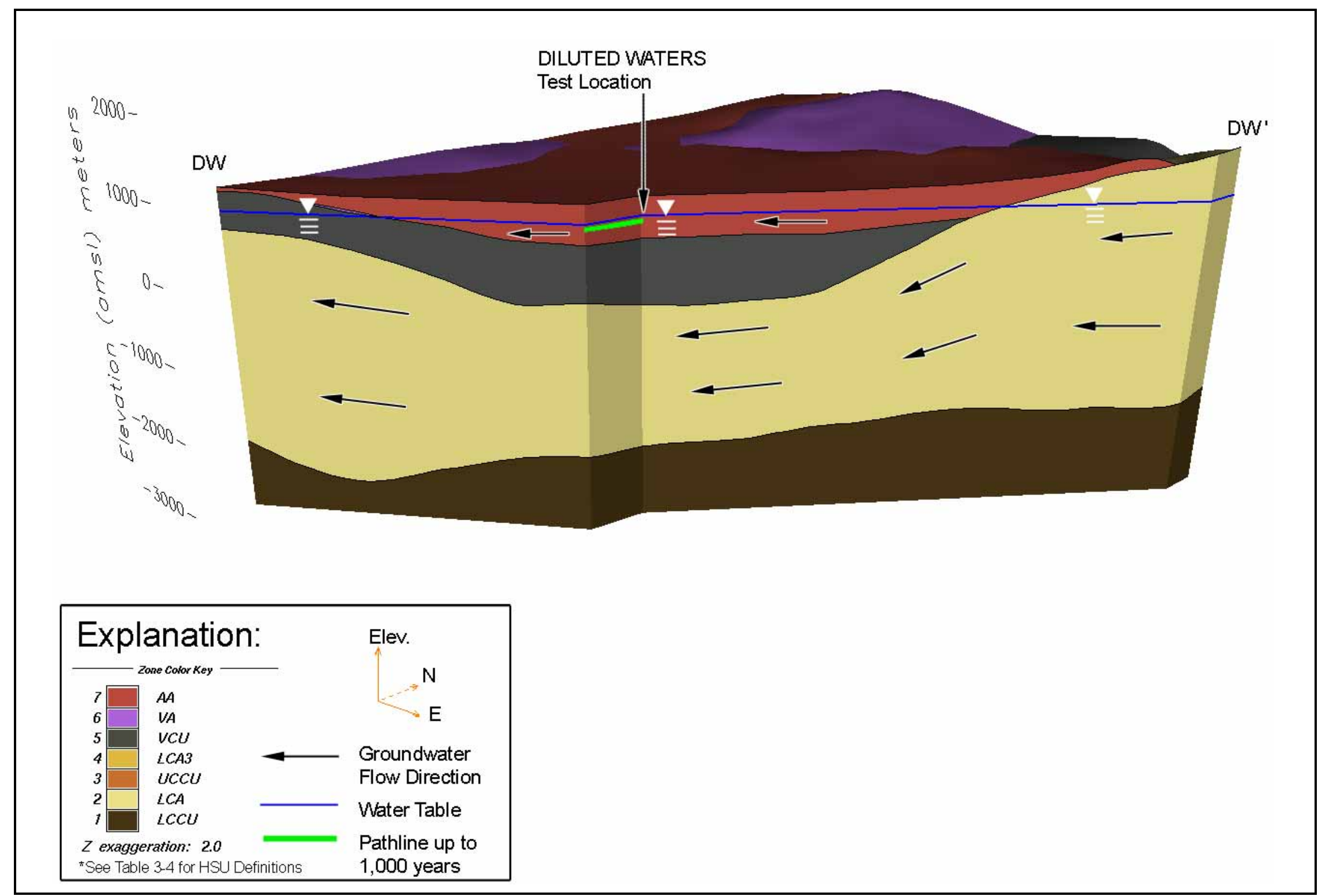

Figure 3-14

Downgradient Distance of $4 \mathrm{mrem} / \mathrm{yr}$ Dose from Location of DILUTED WATERS Nuclear Test in Frenchman Flat, at $95 \%$ Confidence Level and within 1,000 years 


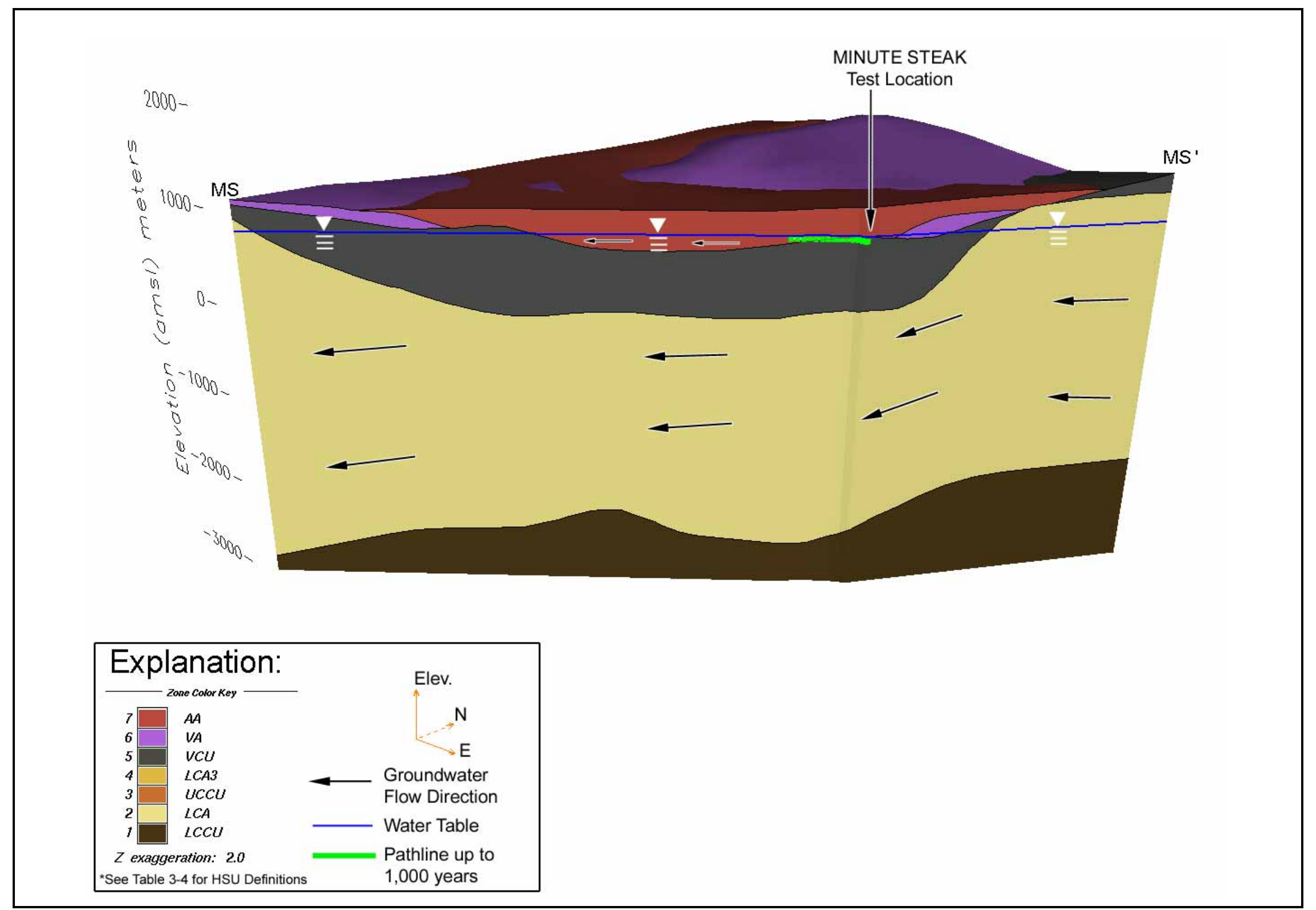

Figure 3-15

Downgradient Distance of $4 \mathrm{mrem} / \mathrm{yr}$ Dose from Location of MINUTE STEAK Nuclear Test in Frenchman Flat, at $95 \%$ Confidence Level and within 1,000 years 


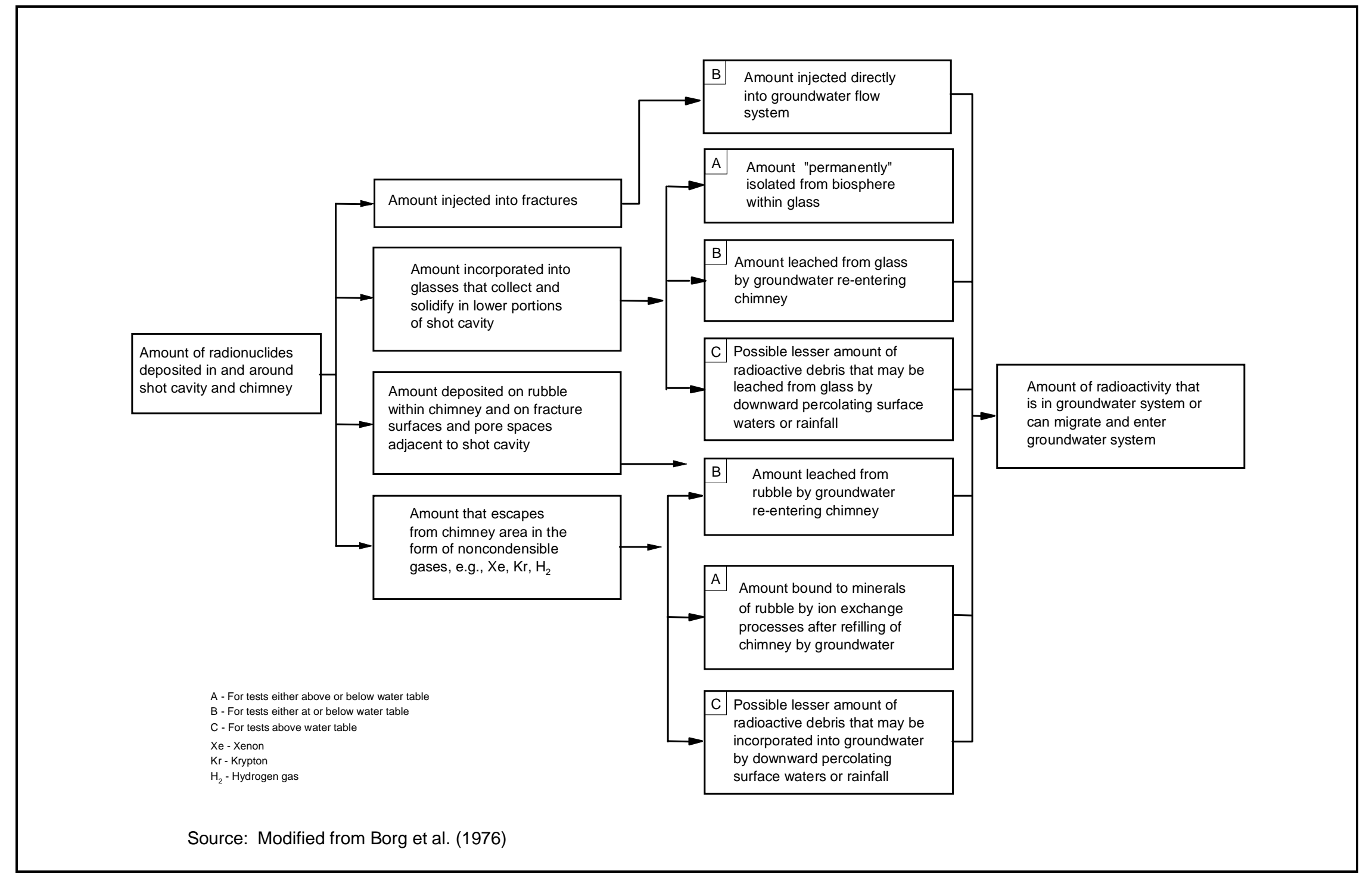

Source: Modified from Borg et al. (1976)

Figure 3-16

Introduction or Distribution of Radionuclides from Underground Tests to Hydrologic Source Term and Groundwater Flow System 
mechanisms that lead to the eventual collapse of the cavity. A discussion of the distribution of materials introduced into the subsurface during nuclear testing and their availability for groundwater transport in groundwater is also included.

\section{Early Time Phenomenology}

Sufficient energy is released when an underground nuclear device is exploded to instantaneously vaporize the experiment canister and the rock surrounding the experiment. Within microseconds of the detonation, initial temperatures rise to several million degrees Kelvin, and pressures of about 1 megabar are created. As a result, a compressive shock wave is generated that imparts momentum on the rock. Additional rock is crushed and cracked within milliseconds. In tenths of seconds, the energy passes elastically through the outlying material to the ground surface.

Rock material surrounding the explosion is vaporized and melted, and pore water is vaporized. The cavity void continues to grow radially as the expanding shock wave imparts outward momentum on the surrounding media. Cavity growth is dependent on the strength of the overlying rock. Depending on the yield of the explosion, the cavity reaches its largest size within 80 to 500 milliseconds when the elastic strains within the rock attempt to recover. The material rebounds radially due to elastic unloading and tries to return to its original position. A compressive tangential hoop stress is formed when the stress field in the rebounded rock is greater than the cavity pressure. This compressive or residual hoop stress closes radial fractures that were opened during cavity expansion. The final size of the cavity is dependent on the yield of the explosion, the overburden stresses, and the strength of the surrounding rock.

The cavity grows slowly as the shock wave moves outward. At about one third of the distance from the detonation point to the ground surface, the shock wave becomes elastic, travels at elastic speeds, and reaches the surface within about 100-500 milliseconds. Rock failure can be brittle or plastic, depending on the stress conditions and the strength properties of the geologic materials. Upward acceleration of material from the detonation point to the ground surface can cause surface bulges of about 1 to $3 \mathrm{~m} \mathrm{(3} \mathrm{to} 9 \mathrm{ft}$ ). Final cavity pressure is not dependent on overburden pressure, but rather on the strength of the overlying rock. Frequently, cavity growth ceases when ambient hydrostatic overpressure is greater than cavity pressure. The cavity stabilizes and dynamic motion ceases within a few seconds of the explosion. 


\section{Late Time Phenomenology}

Rock vapor begins to condense and forms a puddle of melted material at the bottom of the cavity after the shock and elastic waves have dissipated. Water vapor and noncondensable gases, such as carbon dioxide and hydrogen, are still present in the cavity. Energy in the gas is radiated and high thermal gradients are created within the cavity walls via thermal conduction, causing ablation and spalling of wall material. This activity occurs within minutes to hours of the explosion. Flaked wall material of various sizes enhances cooling and mixes with puddle glass. Some material becomes incorporated in the melt and larger pieces survive as rubble within the glass. The repeated ablation and mixing reduces cavity pressure until it is only a few pounds per square inch. Cavity collapse starts within minutes or hours of the explosion and progresses quickly, usually within tens of minutes. If the overlying rock is not strong enough to support the cavity roof span, collapse propagates upwards forming a rubble chimney. If the material strength of the overlying rock is insufficient, collapse proceeds to the surface and a subsidence crater is formed.

\section{Other Phenomena}

Other phenomena related to underground nuclear testing have occurred, including hydrofracturing, prompt injection of radionuclides, groundwater effects (such as mounding and pressurization), reflections off of impedance layers caused by material property differences (such as rock strength or air void content, bedding planes, or faults), and movement on preexisting structural features (such as faults). These may affect cavity growth, residual stress, collapse, and crater formation.

\section{Distribution of Materials Related to Testing}

The nuclear explosion phenomenology described above is responsible for the observed distribution of materials introduced into the subsurface during testing. Radioactive elements are not uniformly distributed in the chimney/cavity region, but are partitioned based on their physical and chemical characteristics.

Smith (1993) indicates that the partitioning can be described in terms of a three stage condensation process. The refractory radionuclides (e.g., actinides), whose melting points are significantly greater than the melting temperature of the adjacent geologic media, are scavenged by the molten material that lines the cavity. These nuclides are volumetrically deposited within the puddle glass. As cavity 
gas moves into the crushed rubble and fractured material surrounding the working point, further condensation takes place. During this stage, the radioisotopes of intermediate volatility, often with gaseous precursors (e.g., ${ }^{137} \mathrm{Cs}$ ), condense and deposit on rubble and fracture surfaces. Final condensation occurs as residual gas ascends toward the ground surface. Condensation during this stage also occurs on surfaces. The above process leads to a distribution of radionuclides that is fractionated, with heavier refractory nuclides concentrated within the glass and lighter and volatile nuclides concentrated higher in the chimney (Smith, 1993). Tritium is initially distributed in the gas phase and later as molecular tritium oxide in steam (Smith, 1995b).

During tests conducted at or below the water table, groundwater is evacuated from the shot cavity and then slowly seeps back into the cavity after detonation (Borg et al., 1976). Where detonations are near or below the static water level, groundwater is impacted due to the prompt injection of radionuclides into surrounding fractures or the leaching of radionuclides as water seeps back into the shot cavity and rubble chimney (Figure 3-16).

The distribution of radionuclides in the cavity/chimney region greatly influences the availability of potential contaminants for transport by groundwater. Radionuclides volumetrically incorporated in the melt glass matrix are accessible to groundwater only through slow processes such as glass dissolution. Other radionuclides are predominantly associated with surfaces and are accessible to groundwater through relatively fast processes such as ion exchange (Smith, 1995b).

In addition, metals, drilling mud, and other organic material may be left within, or in close proximity to, the chimney or shot cavity due to reentry operations. Nonradiological contaminants from these sources can also be leached into groundwater and potentially transported to environmental receptors.

\subsubsection{Discharge Mechanisms}

Contaminants resulting from underground nuclear testing at Frenchman Flat may potentially be discharged to the surface with groundwater. No groundwater discharge occurs within Frenchman Flat or on the NTS downgradient of Frenchman Flat. Access to groundwater in these areas is, therefore, only through open boreholes and water-supply wells. Natural discharge in the vicinity of Frenchman Flat occurs from a few perched springs (e.g., Cane Spring) located along the margins of nearby valleys. However, based on hydrogeologic and geochemical evidence (Laczniak et al., 1996; 
Lyles et al., 1990), the springflow is sustained by local precipitation falling on highlands. The discharges are not from the regional flow system, and thus, it is highly unlikely that groundwater at the perched springs will become contaminated from underground testing.

Groundwater from Frenchman Flat that reaches the regional aquifer will flow past the NTS boundary and eventually reach the major discharge areas of Ash Meadows and possibly Alkali Flat and Death Valley (Laczniak et al., 1996; Winograd and Thordarson, 1975). The discharge areas (springs and evapotranspiration areas) are caused by upflow of groundwater in the carbonate-rock aquifer related to structural thinning of the aquifer (Laczniak et al., 1996). As discussed in Section 3.6.3, the regional model predicts that groundwater from Frenchman Flat discharges in the Amargosa River discharge area, west of Ash Meadows (DOE/NV, 1997).

\subsubsection{Migration Routes}

In order for human receptors to be exposed to radionuclides leached or injected into groundwater near underground nuclear test locations, a transport or migration mechanism must be present. For contaminants generated from underground testing at Frenchman Flat, the most probable potential migration pathway is via transport in the regional groundwater-flow system. A summary of the current understanding of the groundwater flow paths, contaminant concentrations, and travel times is presented in this section.

\subsubsection{Groundwater Flow Paths}

Using the regional flow model and the USGS particle tracking model, MODPATH, Version 1.2 (Pollock, 1989), particle-tracking simulations were performed along pathlines passing through the underground test area of Frenchman Flat. The results indicate that during the 200-year simulation period, the groundwater pathlines passing through the Frenchman Flat underground nuclear tests will remain within Frenchman Flat (Figure 3-17). Groundwater particles are predicted to travel short distances within the Tertiary and Quaternary rock units (DOE/NV, 1997) and the groundwater pathlines will eventually enter the Lower Carbonate Aquifer by lateral movement. Therefore, groundwater flow out of Frenchman Flat and beyond the NTS boundary is predicted to occur within the Lower Carbonate Aquifer. 


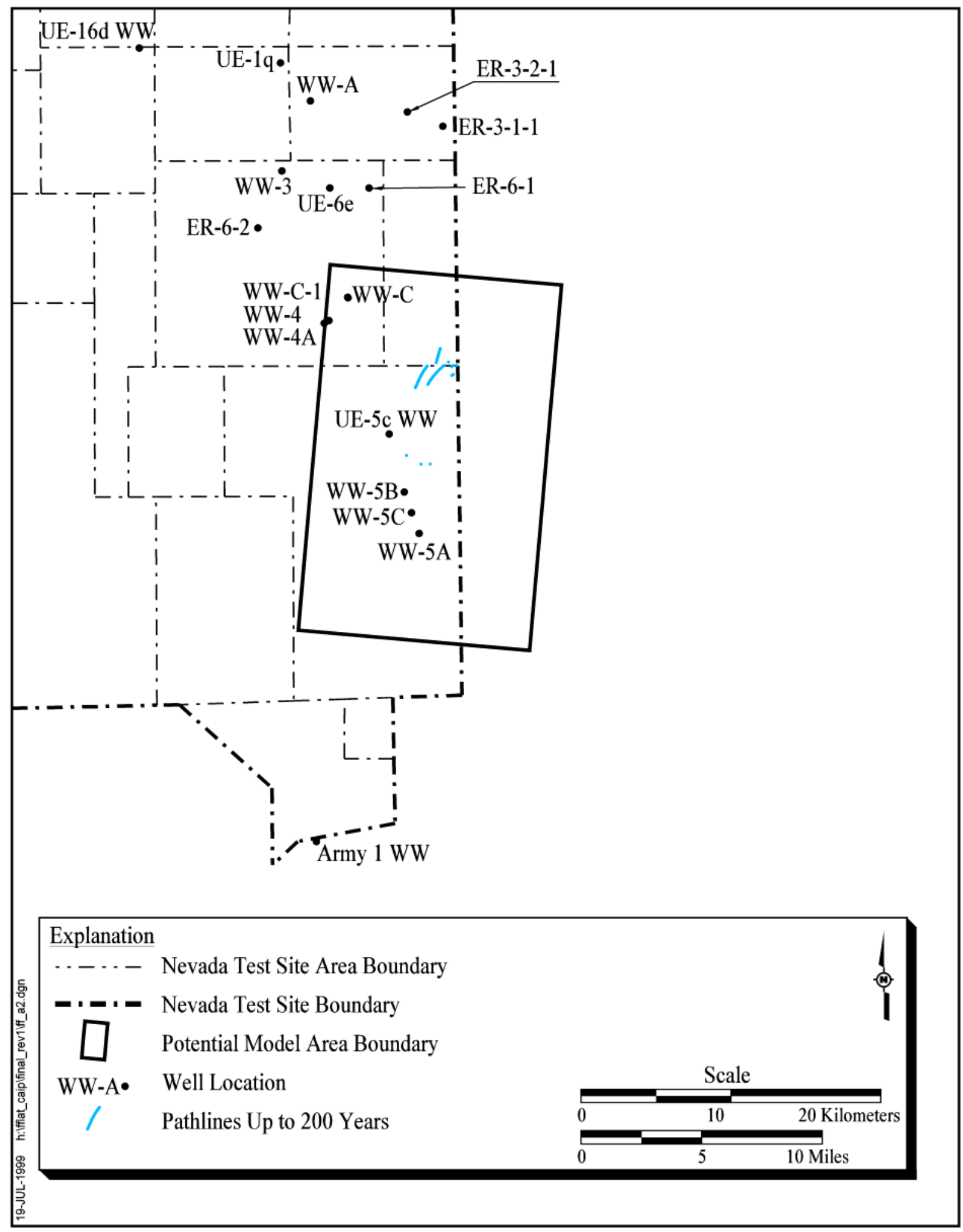

Figure 3-17

Simulated Groundwater Pathlines from Frenchman Flat Nuclear Test Locations for a 200-Year Period 


\subsubsection{Travel Times and Contaminant Concentrations}

No transport simulations were performed for the nuclear tests of Frenchman Flat during the regional evaluation (DOE/NV, 1997); however, transport simulations were performed for two nuclear tests located within the Frenchman Flat CAU during the VOIA (IT, 1997c). The MINUTE STEAK nuclear test has been selected to represent contaminant sources in Area 11 and the DILUTED WATERS nuclear test has been used to represent contaminant sources in Area 5 (Figure 3-1). The pathlines passing through these two tests are very similar, and the base case modeling has been conducted primarily along the DILUTED WATERS pathline.

Regional modeling (DOE/NV, 1997) predicts that potential contamination from DILUTED WATERS moves southwest toward the Amargosa River discharge area. The DILUTED WATERS pathline begins in the Alluvial Aquifer, traverses the underlying Volcanic Confining Unit, and enters the Lower Carbonate Aquifer within Frenchman Flat.

The estimated travel time for a conservative particle from the DILUTED WATERS location is $0.4 \mathrm{~m}$ per year (1.3 ft per year), based on the particle-tracking simulation performed during the regional modeling effort (DOE/NV, 1997). The DILUTED WATERS pathline remained entirely within the Alluvial Aquifer for the 200-year duration of the simulation.

Using the regional model, one-dimensional transport simulations of six of the seven radioactive potential contaminants listed in Table 3-22 were performed in support of the Frenchman Flat VOIA (IT, 1997c). Strontium-90 was not included in the VOIA simulations, because its transport could be reasonably bounded by the simulation of cesium-137 and tritium transport. Base simulations were conducted for the DILUTED WATERS pathline. Alternate horizontal flow simulations were performed for the MINUTE STEAK pathline, and vertical flow path simulations were conducted for the DILUTED WATERS, PIN STRIPE, and NEW POINT pathlines. Except for ${ }^{137} \mathrm{Cs}$, upper-bound source concentrations used in the simulations were at least an order of magnitude greater than the maximum observed test cavity concentrations listed in Table 3-22. The upper bound ${ }^{137} \mathrm{Cs}$ concentration used in the VOIA simulations was approximately three times the observed maximum concentration shown in Table 3-22. 
Considering the 1,000-year time frame of interest, the regional model simulations conducted for the VOIA (IT, 1997c) predicted that contamination from DILUTED WATERS will remain within the Alluvial Aquifer. Based on a 4-mrem/yr dose and a 95-percent confidence level, the contaminant boundary would be located between 1 and $2 \mathrm{~km}(0.6$ and $1.2 \mathrm{mi})$ downgradient of the nuclear test working point. The simulations predicted that tritium would be the dominant radionuclide for the first 80 years, and between approximately 200 and 1,000 years, ${ }^{14} \mathrm{C}$ would be dominant (IT, 1997c). At the 95-percent confidence level, for the 25,000-year maximum duration of the simulations, modeling predicted that the 4-mrem/yr dose boundary from a single source will not reach the Lower Carbonate Aquifer.

Comparison of the simulations conducted for the DILUTED WATERS and MINUTE STEAK pathlines indicate that if flow is horizontal within Frenchman Flat, then radionuclides from the southernmost test locations have the greatest likelihood of reaching the Lower Carbonate Aquifer. This is based on the regional model which shows that travel times to the Lower Carbonate Aquifer are greater for test locations in northern Frenchman Flat, compared to test locations in the central part of the flat.

As discussed above, vertical flux transport simulations were also performed for the VOIA (IT, 1997c). The flow directions were hypothetical and inconsistent with the regional model, but the alternate simulations were included to evaluate the effects of a shorter path to the Lower Carbonate Aquifer in Frenchman Flat. Modeling predicted that at a 95-percent confidence level, the 4-mrem/yr boundary reaches the Lower Carbonate Aquifer relatively quickly. Concentrations of ${ }^{14} \mathrm{C}$ would remain above the 4-mrem/yr level for about 1,200 years before decreasing (IT, 1997c). This estimate does not include the effects of dilution. The location of the 4-mrem/yr boundary in the Lower Carbonate Aquifer was not determined during the VOIA (IT, 1997c).

\subsubsection{Contaminated Media}

Contaminated media are subsurface soils and groundwater within the unsaturated and the saturated zones. Contamination within the unsaturated zone may be transported downward with infiltrated water from precipitation. This vertical movement is, however, extremely slow and is not within the scope of this investigation. Contamination within the saturated zone is subject to much more rapid transport in groundwater and is the focus of this CAI. 
Groundwater contamination occurs within the nuclear test cavities, their vicinity, and potentially downgradient of the Frenchman Flat CAU. The portion of the groundwater flow system that may potentially be contaminated includes all groundwater below the water table within a region stretching from the northern side of Frenchman Flat south and southwestward to the Amargosa River discharge area. Geologic units within this region include porous alluvium, bedded tuffs, fractured welded-tuffs and lava flows, tuffaceous sedimentary rocks, fractured Paleozoic carbonates, and clastic-confining units as described in Section 3.4.

Predictions made during the VOIA (IT, 1997c) using the regional model (DOE/NV, 1997) indicate that the migration of contaminants from underground test locations in Frenchman Flat has been slow,

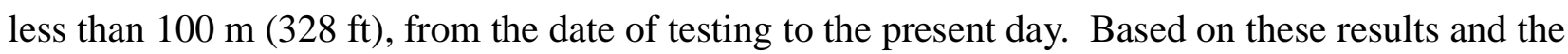
absence of contamination in groundwater wells within Frenchman Flat, potential contamination related to underground testing is currently limited to the test cavities, the geologic media adjacent to the cavities, and perhaps the alluvium and/or volcanic units immediately downgradient of the test locations in Frenchman Flat.

\subsubsection{Exposure Pathways}

Access to Frenchman Flat is restricted; the NTS is not open for public use. The eastern side of Frenchman Flat is part of the Nellis Air Force Range (NAFR), which is not open to the public. The U.S. Bureau of Land Management lands surrounding the NAFR and NTS are used for grazing, mining, and recreation. On-site and off-site users of groundwater are the potential receptors for the Frenchman Flat CAU.

On-site workers and possibly site visitors may be potential receptors from on-site water supply wells. These on-site receptors may be potentially exposed to radionuclides and other hazardous materials in groundwater through ingestion, dermal contact, irradiation, or inhalation (of volatile radionuclides). The existing monitoring program of the water supply wells limits the potential for exposure via this scenario. Environmental receptors (biota) may potentially be exposed to pumped groundwater at on-site surface impoundments. This potential exposure route is very localized and limited in time. Receptors associated with off-site springs and wells include plants, animals, and area residents. Off-site human receptors may be exposed to the potential contaminants in groundwater through ingestion, dermal contact, irradiation, or inhalation. For the purpose of the CAI, the worse-case 
(most protective) scenario of drinking water ingestion is considered in the definition of the contaminant boundary as explained in Section 2.1.2.2.1.

\subsubsection{Uncertainties}

The current conceptual model of the Frenchman Flat CAU has several areas of uncertainties, which are as follows:

- A lack of subsurface characterization exists for the Lower Carbonate Aquifer within Frenchman Flat. Wells completed in the Lower Carbonate Aquifer currently exist only on the periphery of Frenchman Flat.

- The current understanding of the vertical hydraulic gradient and related vertical flux of contamination from the alluvium to the Lower Carbonate Aquifer is limited.

- The current knowledge of the contaminant transport processes and associated parameters is limited.

- The current understanding of the contamination sources is limited.

\subsection{Preliminary Action Levels}

This section provides regulatory and health-based preliminary action levels (PAL) for the potential contaminants upon which decisions for future action for the Frenchman Flat CAU are proposed to be based. Only groundwater PALs are provided, because groundwater is the only affected media from the CAU that could reasonably be assumed to contact receptors.

A PAL is the concentration of a contaminant in drinking water that will result in a member of the public receiving an ingestion dose limit from that contaminant. The PALs for the potential contaminants evaluated in the Frenchman Flat VOIA are presented in Table 3-23. Preliminary action

levels for ${ }^{14} \mathrm{C},{ }^{129} \mathrm{I},{ }^{239 / 240} \mathrm{Pu}$, and ${ }^{238} \mathrm{U}$ were calculated using two methodologies: 40 CFR Part 141.16 (CFR, 1998b) and 10 CFR Part 20 Subpart E (CFR, 1998a). The most restrictive PAL value was then used in this CAIP (Table 3-22). The preliminary actions levels for tritium and ${ }^{90} \mathrm{Sr}$ were not calculated, but were obtained directly from 40 CFR Part 141.16 (CFR, 1998b). All PALs for potential radioactive contaminants listed in Table 3-23 represent average annual concentrations assumed to produce a total body or organ dose of 4-mrem per year. The PAL for lead was obtained from 40 CFR Part 141.80 (CFR, 1998c). 
Table 3-23

Preliminary Action Levels for Potential Contaminants

\begin{tabular}{||c|c|c||}
\hline Contaminant & $\begin{array}{c}\text { Preliminary Action } \\
\text { Level (PAL) }\end{array}$ & $\begin{array}{c}\text { Regulatory Source for } \\
\text { PAL }\end{array}$ \\
\hline \hline Tritium & $2 \mathrm{E}+04 \mathrm{pCi} / \mathrm{L}$ & $40 \mathrm{CFR} 141.16$ \\
\hline Cesium-137 & $5 \mathrm{E}+01 \mathrm{pCi} / \mathrm{L}$ & $40 \mathrm{CFR} 141.16$ \\
\hline Plutonium-239/240 & $1.6 \mathrm{E}+00 \mathrm{pCi} / \mathrm{L}$ & $10 \mathrm{CFR} 20$ Part $\mathrm{E}$ \\
\hline Carbon-14 & $2 \mathrm{E}+03 \mathrm{pCi} / \mathrm{L}$ & $40 \mathrm{CFR} 141.16$ \\
\hline Strontium-90 & $8 \mathrm{E}+00 \mathrm{pCi} / \mathrm{L}$ & $40 \mathrm{CFR} 141.16$ \\
\hline Uranium-238 & $2.2 \mathrm{E}+01 \mathrm{pCi} / \mathrm{L}$ & $10 \mathrm{CFR} 20$ Part $\mathrm{E}$ \\
\hline lodine-129 & $5 \mathrm{E}-01 \mathrm{pCi} / \mathrm{L}$ & $40 \mathrm{CFR} 141.16$ \\
\hline Lead & $1.5 \mathrm{E}+01 \mu \mathrm{g} / \mathrm{L}$ & $40 \mathrm{CFR} 141.80$ \\
\hline
\end{tabular}

Note: Lead as a potential contaminant is representative of other inorganic, nonradioactive, hazardous constituents. According to Bryant and Fabryka-Martin (1991), lead was used in quantities of tens of tons in underground nuclear tests, while other inorganic, potentially hazardous substances were used in kilogram or smaller quantities. Generally, the introduced quantities are on the same scale as the quantity that would melt in the rock as a result of the detonation.

$\mu \mathrm{g} / \mathrm{L}=$ Microgram(s) per liter

$\mathrm{pCi} / \mathrm{L}=$ Picocurie(s) per liter 


\subsection{Summary of Data Quality Objectives}

The DQO process for the Frenchman Flat CAU was conducted in 1996. This section presents a summary of the DQO process detailed in Appendix A. The summary includes a discussion of the DQO approach and the results. The Frenchman Flat VOIA (IT, 1997c) which was used to support the DQO process is also discussed. In addition, a discussion of how the results of the DQO process relates to the migration routes is presented.

\subsection{Data Quality Objectives Approach}

The purpose of the DQO process is to define the environmental problem to be solved, identify any information needed to resolve the problem, and identify an investigation program to gather the missing information. The approach used for Frenchman Flat is the seven-step method (EPA, 1993 and 1994), supported by the VOIA (IT, 1997c). The DQO process and the VOIA approaches used for the Frenchman Flat CAI are summarized in this section.

\section{DQO Seven-Step Method}

Descriptions of the seven steps of the DQO process provided in the EPA guidance (EPA, 1994) are as follows:

- $\quad$ Step I: State the Problem - Concisely describe the problem to be studied. Review prior studies and existing information to gain a sufficient understanding to define the problem.

- Step II: Identify the Decision - Identify what questions the study will attempt to resolve, and what actions may result.

- Step III: Identify the Inputs to the Decision - Identify the information that needs to be obtained and the measurements that need to be taken to resolve the decision statement.

- Step IV: Define the Study Boundaries - Specify the time periods and spatial study area to which the decisions will apply. Determine where and when data should be collected.

- Step V: Develop a Decision Rule - Define the statistical parameter of interest, specify the action level, and integrate the previous DQO outputs into a single statement that describes the logical basis for choosing among alternative actions. 
- Step VI: Specify Tolerable Limits on Decision Errors - Specify the decision maker's tolerable decision error rates based on a consideration of the consequences of making an incorrect decision.

- Step VII: Optimize the Design - Evaluate information from the previous steps and generate alternative data collection designs. Choose the most resource-effective design that meets all DQOs.

As stated before, the DQO process was supported by the VOIA (IT, 1997c). The regional model (DOE/NV, 1997) and the FFACO (1996) also played major supporting roles in the DQO process. The relationships between the DQO process and these supporting tasks are illustrated in Figure 4-1. As shown in Figure 4-1, the VOIA contributed to the conceptual model of Frenchman Flat (Step I), the identification of the inputs to the decision (Step III), and the optimization of the design (Step VII). The regional model (DOE/NV, 1997) was used as the basis for the Frenchman Flat conceptual model (Step I) and the FFACO (1996) was used to identify the decisions (Step II) and develop the decision rules (Step V). The specific VOIA approach is summarized in the following text.

\section{Value of information Analysis}

A VOIA was conducted in support of the DQO process (IT, 1997c). The VOIA was, in essence, a part of the DQO process. The VOIA focused on the assessment of activities that could be undertaken to reduce the uncertainty in the prediction of a contaminant boundary for the Frenchman Flat CAU.

A nonprobabilistic approach was used to identify the quantity and quality of the potential additional data needed for Frenchman Flat during the VOIA. This is not inconsistent with the EPA approach (EPA, 1993). As stated by EPA (1993), statistical procedures may not be applied to certain environmental problems. "Non-probabilistic or subjective (judgmental) sampling approaches can be useful and appropriate for satisfying certain field investigation objectives (EPA, 1993)." The approach used to evaluate the characterization activities for Frenchman Flat was specifically directed at filling the relevant data gaps.

The VOIA included the following steps:

- Compilation of existing data from the regional data documentation packages and literature (DQO Step 1) 


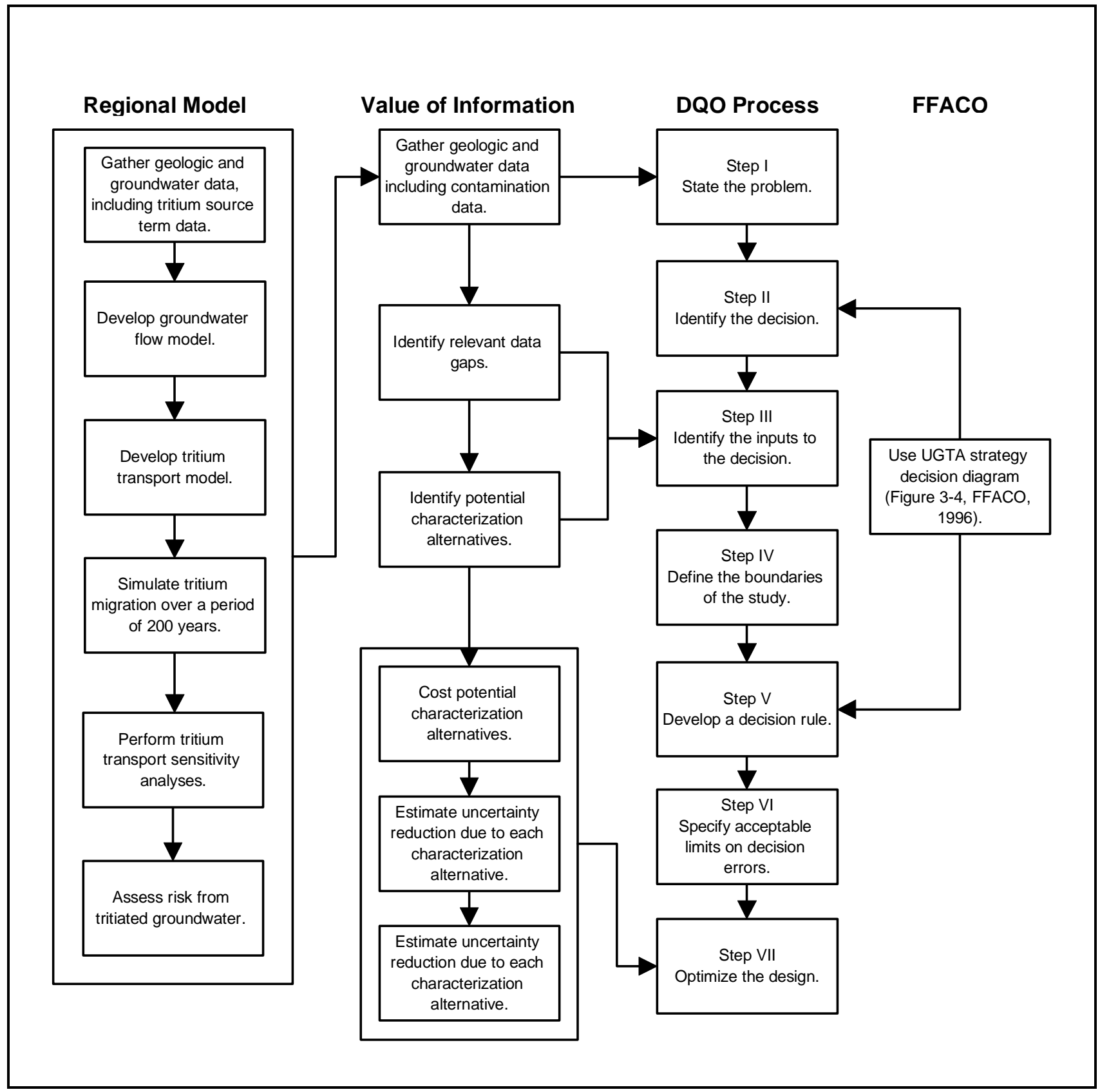

Figure 4-1

Relationship Between DQO Process and Supporting Tasks 
- $\quad$ Identification of data gaps (DQO Step III)

- Identification of potential data-collection and analysis options to fill the data gaps (DQO Step III)

- Costing of data-collection and analysis options (DQO Step VII)

- Estimation of uncertainty reduction through expert opinion (DQO Step VII)

During the decision analysis, parameter sensitivities and probabilistic values associated with a data gathering and analysis option were used to calculate a radioactive dose and a corresponding distance. The estimated improvement in parameter uncertainty and the change in distance to the contaminant boundary were then related to the cost of the corresponding data gathering option. Alternatives are then compared and a set of optimum alternatives is proposed.

\subsection{Data Quality Objectives Results}

The results of the DQO process are summarized in this section. The discussion includes the results of the seven-step DQO method (EPA, 1993 and 1994) and the results of the VOIA.

\subsubsection{Results of DQO Seven-Step Method}

The results of each of the seven steps of the EPA DQO method are summarized in the following text. The worksheets documenting the process are presented in Appendix A.

\section{Step I: State the Problem}

Ten underground nuclear tests were detonated in Frenchman Flat between 1965 and 1971. All tests were detonated in the alluvial and volcanic rocks, which overlie the Lower Carbonate Aquifer, a

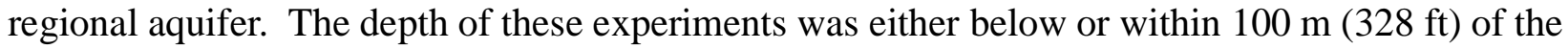
shallow water table in the alluvial material. Based on this information, it is assumed that groundwater in the vicinity of each test was contaminated. Potential contaminants include radionuclides used and/or created during the experiment and possibly other hazardous constituents used in the preparation and/or conducting of the tests. The primary route of migration of this contamination is via the groundwater, which is believed to be flowing horizontally through the Alluvial Aquifer, although a potential for vertical contaminant movement to the Lower Carbonate Aquifer exists. 
Current and future land uses include surface waste management and research facilities. With the exception of one water supply well, the groundwater in this area is not being utilized. No known receptors of the contaminated groundwater currently exist. However, a potential for human and environmental receptors in the future exists. Potential exposure pathways for humans include groundwater ingestion, dermal contact and inhalation. However, for purposes of conducting the CAI, a conservative exposure scenario will be used: ingestion of contaminated groundwater by a human receptor. This conservative scenario is protective of environmental receptors also.

Specific, proven, cost-effective remedial technologies that are protective of worker safety and health do not currently exist. The currently preferred remedial alternative is long-term monitoring. Thus, the objective of the corrective action investigation process is to define a contaminant boundary around the Frenchman Flat CAU that establishes an area containing water that may be unsafe for domestic and municipal use (FFACO, Appendix VI, page 3-3 [FFACO, 1996]). The contaminant boundary restrictions are a dose rate limit defined as $4 \mathrm{mrem} / \mathrm{yr}$ with a 50 percent confidence level, representing the median value, over a 1,000-year period using the drinking water exposure scenario.

\section{Step II: Identify the Decision}

Consistent with the FFACO strategy (FFACO, 1996), the decision at hand is whether or not a reliable contaminant boundary can be predicted using a CAU-specific model based on existing data. This decision is equivalent to whether or not the existing data are sufficient to predict an acceptable contaminant boundary location. The CAU model developed using the existing data will be reviewed by a peer review panel, DOE, and NDEP. If the CAU model is not rejected, it will be verified and a contaminant boundary will be simulated. If the CAU model is rejected, the strategy will be evaluated to determine if it is achievable. If it is still achievable, DOE/NV will collect additional data. Additional field investigations may also be necessary if the CAU model cannot provide an acceptable contaminant boundary location based on existing data only. The logical sequence of actions will follow the flow chart shown in Figure 3-4 in the FFACO (1996) and presented in Figure 2-1 of this CAIP. 


\section{Step III: Identify Inputs to the Decision}

The inputs to the decision were identified during the VOIA (IT, 1997c). The existing data were reviewed, the areas of uncertainty were identified, and potential characterization options designed to reduce uncertainty were proposed.

The information needed for the decision is that necessary to build a groundwater flow and contaminant transport model of the problem area that represents reality at an acceptable level of uncertainty. This information consists of geologic data, groundwater data including contamination sources and concentrations in groundwater, and an understanding of the processes that control contaminant migration in groundwater. The existing data were obtained from the regional evaluation report (DOE/NV, 1997) and the documentation packages (IT, 1996a through f; IT, 1997a and b). This information was used to define the current conceptual model which is described in detail in Section 3.6 and summarized in Section I.B (Develop/Refine Conceptual Model) of the DQOs (Appendix A).

The areas of uncertainty that exist in this conceptual model correspond to data or information gaps identified during the regional evaluation. These include data gaps in uncharacterized portions of the area of interest, and uncertainty in the relationship between the Lower Carbonate Aquifer to the overlying HSUs. Other areas of uncertainty include an insufficient understanding of the sources of contamination and the transport processes at work in the groundwater flow system. The sensitivity and uncertainty analysis identified the most important uncertainty as a vertical flux for contaminant migration from the alluvium of Frenchman Flat to the Lower Carbonate Aquifer. However, if a significant component of vertical flux exists, any contaminant solute reaching the Lower Carbonate Aquifer would be further diluted by the regional groundwater flow system.

Potential data-collection options designed to reduce these uncertainties include the characterization of the following components of the groundwater flow and contaminant transport model.

- Geology

- Vertical Gradient

- Vertical Hydraulic Conductivity

- Horizontal Gradient

- Horizontal Hydraulic Conductivity 
- Source Term

- Alluvium Transport Parameters

- Volcanic Transport Parameters

- Carbonate Transport Parameters

- Distribution Coefficient

\section{Step IV: Define the Boundaries of the Study}

The domain within which all decisions must apply includes the subsurface of Frenchman Flat CAU. The population of interest include geologic data, groundwater data including contamination sources and concentrations in groundwater, and an understanding of the processes that control contaminant migration in groundwater. Much of this information may be subdivided into two groups: information about hydrostratigraphic units and information about the sources of contamination. The scale of decision making will depend on the predicted location of the contaminant boundary within 1,000 years.

Practical constraints on potential data collection include the following:

- Worker health and safety

- Budget limits and CAU spending priorities

- Classified information

- Regulations (permitting, Federal Facility Agreement and Consent Order)

- Schedule (Federal Facility Agreement and Consent Order deadlines)

\section{Step V: Develop a Decision Rule}

The parameter that characterizes the population of interest is dose for radionuclides. The action level for the decision is $4 \mathrm{mrem} / \mathrm{yr}$ at the 50 percent confidence level for radionuclides. For chemicals, it is as required in the Nevada Administrative Code (NAC, 1998).

The decision rule is consistent with the UGTA strategy (See Figure 2-1 of this CAIP) and may be stated as follows: If the uncertainty in the $4 \mathrm{mrem} / \mathrm{yr}$ boundary or the chemical of concern action level is unacceptable, then the problem will be reevaluated and negotiated as needed. 


\section{Step VI: Specify Acceptable Limits on Decision Errors}

The parameters of interest are the concentrations of the contaminants of concern. The upper bound is the region above the action limit where there is a very high comfort level that sample analysis results would correctly identify the sample as contaminated. The lower bound is the detection limit as specified in the laboratory Statement of Work. If the simulated contaminant boundary is larger than the actual contaminant transport, then more water resources have been restricted than necessary. If the simulated contaminant boundary is smaller than the actual contaminant transport, then less groundwater will be restricted than is necessary to ensure protection of human health and the environment.

\section{Step VII: Optimize the Design}

The decision analysis part of the VOIA (IT, 1997c) was used to support the optimization of the design. The decision analysis consisted of evaluating the estimated improvement in parameter uncertainty and the change in distance from the contaminant source to the contaminant boundary, and relating them to the cost of each data-gathering alternative. Alternatives included individual data gathering and analysis options described in Step 3, and combinations of these individual options. The regional predictions of contaminant boundaries and the sensitivity analysis of flow and transport parameters were used as screening tools to simplify the decision analysis. The decision model considered ${ }^{14} \mathrm{C}$ contamination as a surrogate for the contaminants in the groundwater.

Conclusions from the VOIA for Frenchman Flat (IT, 1997c) are as follows:

- Existing data for Frenchman Flat are insufficient to determine whether a significant component of vertical flux from the alluvium to the Lower Carbonate Aquifer exists.

- A vertical flux could significantly extend the predicted contaminant boundary if basin contamination is introduced into the regional groundwater system of the Lower Carbonate Aquifer.

- If contamination is limited to the alluvium of Frenchman Flat, the major categories of uncertainty in the contaminant boundary are related to horizontal flux, the source term, and other transport parameters such as effective porosity, matrix diffusion, and adsorption. 
- Activities that would reduce the uncertainty for a contaminant boundary in the Alluvial Aquifer are not cost-effective because the improvement in predicting the contaminant boundary location is small when compared with the large investment costs.

The study also stated that if modeling using the new information predicts contaminant transport from the Alluvial Aquifer to the Lower Carbonate Aquifer, additional data could be required to resolve the vertical flux issue. Based on the results of the VOIA (IT, 1997c), the TWG concluded that the most cost-effective approach to reducing uncertainty in the prediction of the location of the Frenchman Flat CAU contaminant boundary would be to perform modeling prior to any additional data collection. The need for additional data would be determined based on the modeling results.

Therefore, no additional characterization activities were deemed necessary under the most-likely scenario of contamination transport in the Alluvial Aquifer. Thus, the CAI will include the on-going studies and CAU modeling activities only. The CAU modeling activities are as follows:

- Develop a CAU-scale groundwater flow and contaminant transport model for Frenchman Flat using existing data only.

- Use the CAU model to predict the location of the contaminant boundary based on the most likely conceptual model of groundwater flow and transport.

- Evaluate other alternate conceptual models and their impact on the location of the contaminant boundary.

If transport simulations performed using any one of the alternate conceptual models show that the potential exists for significant vertical contamination movement into the Lower Carbonate Aquifer, additional characterization activities will be considered.

\subsection{Relationship Between DQO Results and Migration Routes}

The DQO results established that no new data were warranted prior to the development of the groundwater flow and contaminant transport model. The decision analysis performed during the VOIA (IT, 1997c) showed that data-collection activities that would reduce the uncertainty for a contaminant boundary in the Alluvial Aquifer are not cost-effective. Thus, the existing data were deemed sufficient to simulate migration through the most probable migration route, via the Alluvial Aquifer, where slow groundwater velocities prevail. The faster migration route, through the Lower 
Carbonate Aquifer, is believed to be unprobable. This migration route will be evaluated using the CAU-scale model. If the CAU modeling shows that one or more plausible scenarios could cause this route to be more significant than currently thought, then data will be collected to characterize the vertical component of groundwater flow. 


\subsection{Corrective Action Investigation}

As a part of the corrective action investigation proposed for the Frenchman Flat Corrective Action Unit, the location of the contaminant boundary (as described in Section 2.1.2.2.1) will be predicted using a numerical model that simulates groundwater flow and contaminant transport at the CAU scale. This section includes a description of this CAU-scale model and other supporting models.

\subsection{Groundwater Flow and Contaminant Transport Model}

An overview of the modeling process that will be used for the Frenchman Flat CAU is presented, followed by detailed descriptions of all the steps involved.

\subsubsection{Modeling Process Overview}

A modeling protocol for developing valid models for the UGTA CAUs was modified from the Standard Guide for Application of a Ground Water Flow Model to a Site Specific Problem - ASTM D 5447-93 (ASTM, 1993a). This American Society for Testing and Materials (ASTM) document applies to groundwater flow models; the procedure was modified to cover both a groundwater flow and a contaminant transport model. The modeling protocol consists of a series of steps, which when followed builds support in demonstrating that a given site-specific model is capable of producing meaningful results (Figure 5-1). The steps of the modeling protocol are as follows:

- 1 - Establish model objectives

- 2 - Assess data

- 3 - Select a computer code

- 4 - Construct model (design and calibrate model)

- 5 - Perform sensitivity analyses

- 6 - Perform uncertainty analyses

- 7 - Review model

- 8 - Verify model

- 9 - Perform predictive simulations

- 10 - Present model results

- 11 - Perform postaudit

This modeling protocol is consistent with the UGTA modeling approach outlined in a document titled: Corrective Action Unit Modeling Approach for the Underground Test Area, Nevada Test Site, Nye County, Nevada (IT, 1998) in terms of the modeling objectives and the major steps. 

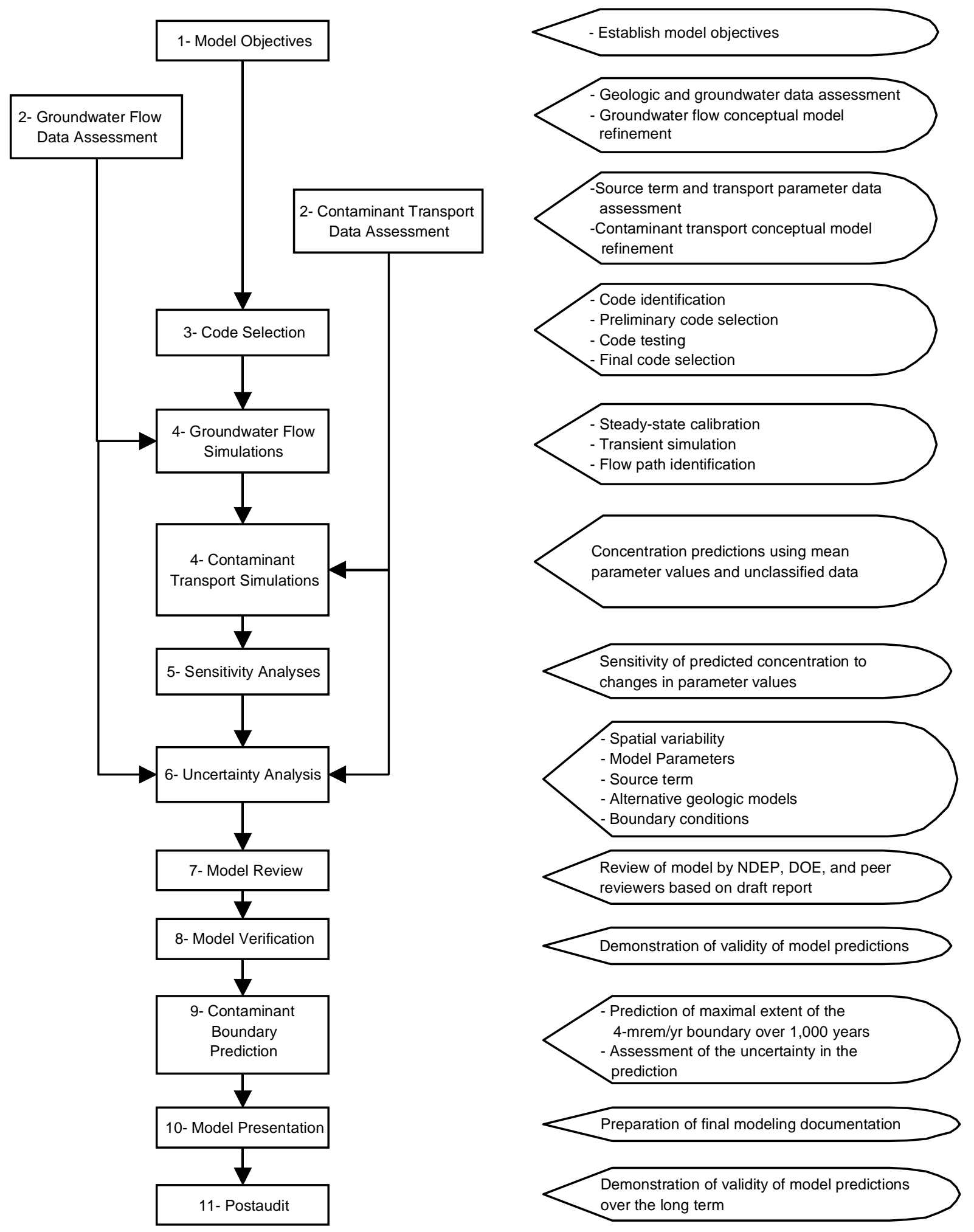

Figure 5-1

Modeling Process for the Frenchman Flat CAU 
As shown in Figure 5-1, the first step in the modeling process is establishing the model objectives. The second step is assessing the relevant available data. The third step is selecting a computer code. The code selection and data assessment steps are conducted in parallel. The data assessment process includes groundwater flow and contaminant transport data assessment leading to interpretations and conceptualization of the groundwater flow system and contaminant transport model. This data assessment is more extensive than that performed for the data presented in this CAIP and will result in some additions to the data presented in Section 3.0 of this document. Code selection is the process used to identify the computer code that will simulate the contaminant migration at the CAU-scale. The fourth step consists of constructing the groundwater flow and contaminant transport model. Sensitivity analyses (fifth step) follow the transport model simulations to assess the response of the predicted concentration values to changes in parameter values. The uncertainty of the predicted concentrations caused by the uncertainty in the data is then quantified (sixth step). Following completion of the model, the model will be reviewed (draft report) and revised (seventh step). If the model is not rejected by DOE and NDEP, a plan for verification is prepared. The model predictions are verified using data not used before (eighth step). The contaminant boundary is calculated after the model has been verified (ninth step). Following completion of the model, the model results are presented in a final report (tenth step). The eleventh and final step in the development of a model is the postaudit performed at a later time to further verify the model results.

The end of each modeling step corresponds to a major decision point during the modeling process. The findings of each modeling step are documented in a product which is either a technical report, a plan, or an FFACO document (Table 5-1) These products are then reviewed by the DOE/NV UGTA Project Manager, NDEP, modeling experts and representatives of the TWG as appropriate. The decisions are then made by the DOE/NV UGTA Project Manager based on the results of the product review for each modeling step. The approximate schedule for the Frenchman Flat CAIP up to the start of the prediction of the contaminant boundary is shown in Figure 5-2. As stated in Section 2.1.2, DOE/NV will keep NDEP informed of the progress of all CAI activities. 
Table 5-1

Modeling Products

\begin{tabular}{||c|c||}
\hline Modeling Step & Products \\
\hline \hline Geologic Data Assessment & \multirow{2}{*}{ Groundwater Data Documentation Package } \\
\hline Hydrogeologic Data Assessment & \\
\hline Contaminant Transport Data Assessment & \\
\hline Groundwater Flow Model & \\
\hline Contaminant Transport Model & CAU Model Documentation Package \\
\hline Sensitivity Analyses & \\
\hline Uncertainty Analyses & \\
\hline Model Review & Model verification plan \\
\hline Model Verification & CADD \\
\hline Contaminant Boundary Prediction & \\
\hline
\end{tabular}

\subsubsection{Model Objectives}

The objectives of a given model guide the level of detail and accuracy required of the model. The CAU-scale model will be used to integrate a wide variety of data into a mass conservative description of contaminant migration in groundwater from underground nuclear test locations in a CAU. This CAU model is then used as a decision-making tool for that CAU during the CAI. In the terms of ASTM (1995), Standard Guide for Subsurface Flow and Transport Modeling, a hydrologic model can be termed an aquifer simulator. This means that the model is used to assess the value of unknowns at specific locations and times, which requires a high degree of correspondence between the simulations and the physical hydrogeologic system. To the extent practicable, the model is designed to honor observed data to a specified degree of confidence by following a calibration process.

The specific objectives of the CAU-scale model are as follows:

- Develop a CAU model that has the ability to represent the physical and chemical features of the CAU groundwater flow system important to contamination migration, using the existing and newly-collected data. 


\begin{tabular}{|c|c|c|c|c|c|c|c|c|c|c|c|c|}
\hline \multirow{2}{*}{ Task Name } & \multicolumn{2}{|c|}{1997} & \multicolumn{3}{|c|}{1998} & \multicolumn{4}{|c|}{1999} & \multicolumn{3}{|c|}{2000} \\
\hline & $3^{\text {rd }}$ Quarter & $4^{4^{\text {th }} \text { Quarter }}$ & \begin{tabular}{|l|l|}
$1^{\text {st }}$ Quarter & $2^{\text {nd }}$ Quarter \\
\end{tabular} & $3^{\text {rd }}$ Quarter & $4^{\text {th }}$ Quarter & $1^{\text {st }}$ Quarter & $2^{\text {nd }}$ Quarter & $3^{\text {rd }}$ Quarter & $4^{\text {th }}$ Quarter & $1^{\text {st }}$ Quarter & $2^{2^{\text {nd }} \text { Quarter }}$ & $3^{\text {3rd Quarter }}$ \\
\hline Assess geologic data & & & & & & & & & & & & \\
\hline Assess groundwater data & & & & & & & & & & & & \\
\hline Select a computer code & & & & & & & & & & & & \\
\hline Construct flow model & & & & & & & & & & & & \\
\hline Construct transport model & & & & & & & & & & & & \\
\hline Perform sensitivity analyses & & & & & & & & & & & & \\
\hline Perform uncertainty analyses & & & & & & & & & & & & \\
\hline Prepare draft modeling document & & & & & & & & & & & & \\
\hline Review model & & & & & & & & & & & & \\
\hline Revise model & & & & & & & & & & & & \\
\hline Revise modeling document & & & & & & & & & & & & \\
\hline Prepare verification plan & & & & & & & & & & & & \\
\hline Predict contaminant boundary & & & & & & & & & & & & \\
\hline
\end{tabular}

Figure 5-2

Approximate Schedule for Frenchman Flat Corrective Action Investigation Activities 
- Simulate the concentration of individual contaminants downgradient of underground test locations over a time period of 1,000 years and define a contaminant boundary based on a $4 \mathrm{mrem} / \mathrm{yr}$ composite dose using the simulated concentrations.

- Use the CAU model as a tool to evaluate impacts of future flow system changes on the migration of contaminants in the CAU.

\subsubsection{Data Assessment}

Existing data will be assessed and used to develop a groundwater flow and contaminant transport of the Frenchman Flat CAU. The conceptual model defines the characteristics and dynamics of the groundwater flow system, the sources of contamination, and contamination migration routes including the processes at work. Section 3.6 of this document provides a description of the current conceptual model of groundwater flow and contaminant transport. The data used to construct the current conceptual model are presented in the documentation of the UGTA regional model (IT, 1996a through f; IT, 1997a and b) and included in a summary form in Sections 3.4 and 3.5 of this CAIP. The data utilization during the CAU modeling process is illustrated in Figure 5-3. The existing data to be assessed include the following:

- Data used to prepare this CAIP (Section 3.0)

- Historic data from the Weapons Program and from public and private sources

- Data from on-going monitoring activities such as the Hydrologic Resources Management Program (HRMP) and the ERP

The CAU-specific data will have the highest priority. However non-CAU specific data may be included in the development of the conceptual model, particularly to provide additional constraints on parameter uncertainty.

Information from existing databases will be acquired in electronic and hard-copy formats. The needed data will be identified from published and unpublished literature and maps. The NTS-user agencies, contractors, and support organizations will help in locating and screening the data. The data will then be compiled into a comprehensive database for the Frenchman Flat investigation. Key data types will then be qualified according to the procedure described in Section 7.0. More detailed descriptions of the data types needed for the groundwater flow model and the contaminant transport model are provided in the following sections. 
Assess relevant data consisting of the following:

-Data used to prepare this CAIP (Section 3.0)

-Additional historic data from the Weapons Program and from public and private sources -Data from on-going monitoring activities such as the HRMP and the ERP

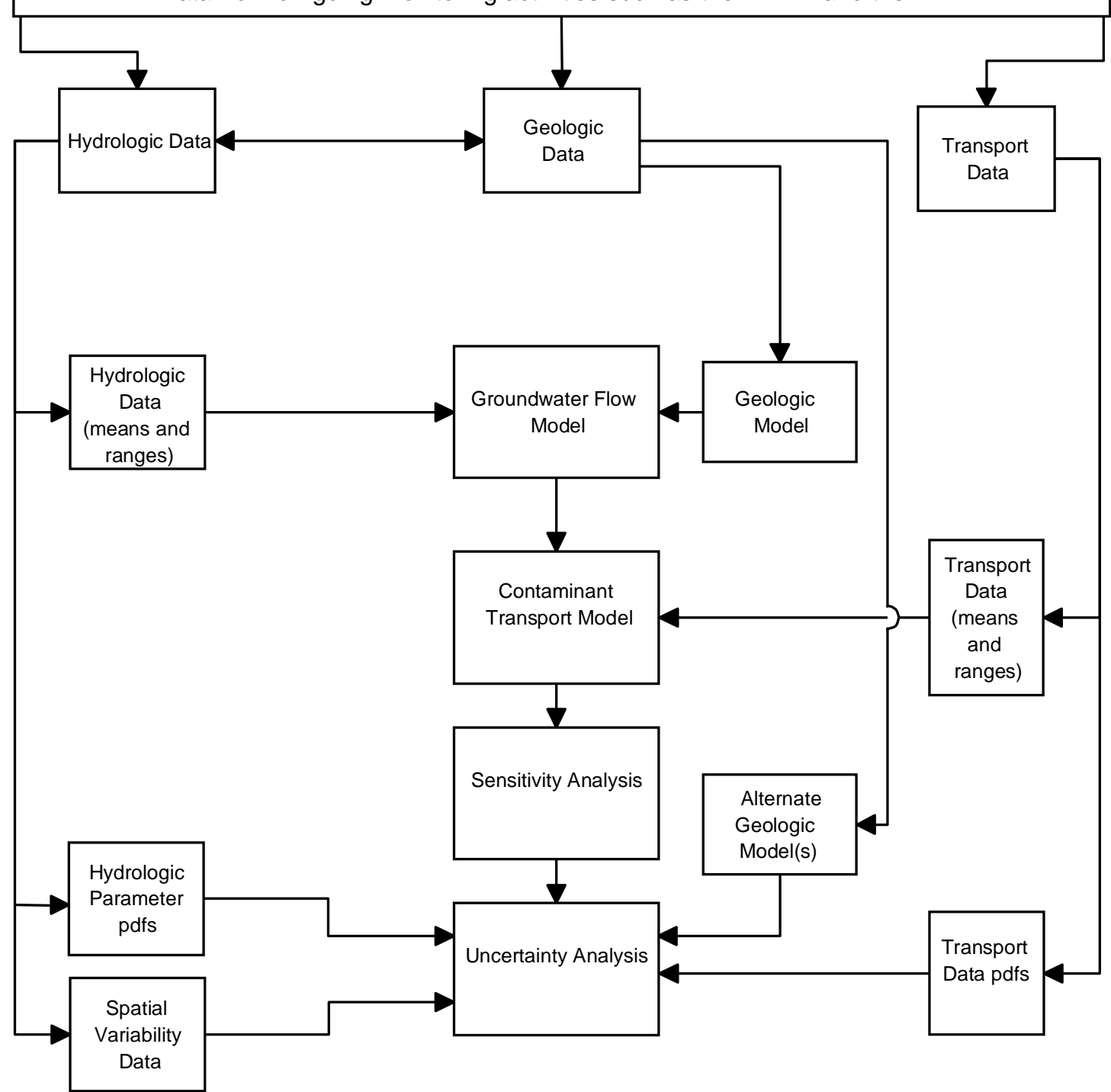

pdf: probability density function

Figure 5-3

Data Utilization During the CAU Modeling Process 


\subsubsection{Data Assessment for Groundwater Flow Model}

The data types required to develop a conceptual model of the groundwater flow system are: geologic data, hydraulic head data, groundwater geochemical data, recharge and discharge estimates, and hydraulic conductivity data. These data types and their utilization in the groundwater flow model are illustrated in Figure 5-4. Geologic data are needed to set up the framework within which groundwater flows. Hydraulic head data serve as a target to which the groundwater flow model is calibrated. Recharge refers to either lateral flow across the groundwater flow model boundary into the model area or recharge that enters from the land surface. Discharge is the lateral flow across the groundwater flow model boundary out of the model area or discharge to springs, seeps, or wells. The hydraulic conductivity is a measure of the water-transmitting ability of the aquifer system. Hydraulic conductivity may be heterogeneous and vary from location to location within an aquifer unit and vary across geologic units. The geochemical data are used to provide an additional check on the calibrated flow directions.

\section{Geologic Data}

A geologic model of the Frenchman Flat region will be constructed to define the framework of the groundwater flow system. The methodology to be used consists of data compilation, conceptual geologic model development, and digital geologic model development. The existing geologic data will be compiled and evaluated. To develop the conceptual geologic model, detailed structural cross sections will be drawn to depict structural and stratigraphic features and will then be simplified to focus on hydrostratigraphic cross sections. In these hydrostratigraphic sections, detailed stratigraphy will be categorized in HSUs with only hydrologically significant structures being depicted. The geologic data and digitized cross sections will be integrated into a three-dimensional, digital model using the Geographic Information System-Based Environmental Resources Management Applications software. The geologic model will provide HSU thicknesses to be used in the design of the groundwater flow model layers.

\section{Hydraulic Heads}

Hydraulic head data define the pressure conditions in the aquifer system. Hydraulic heads are derived from measured water levels. Existing and newly acquired water-level data measured in wells and boreholes located within the investigation area will be compiled and evaluated for use in the 


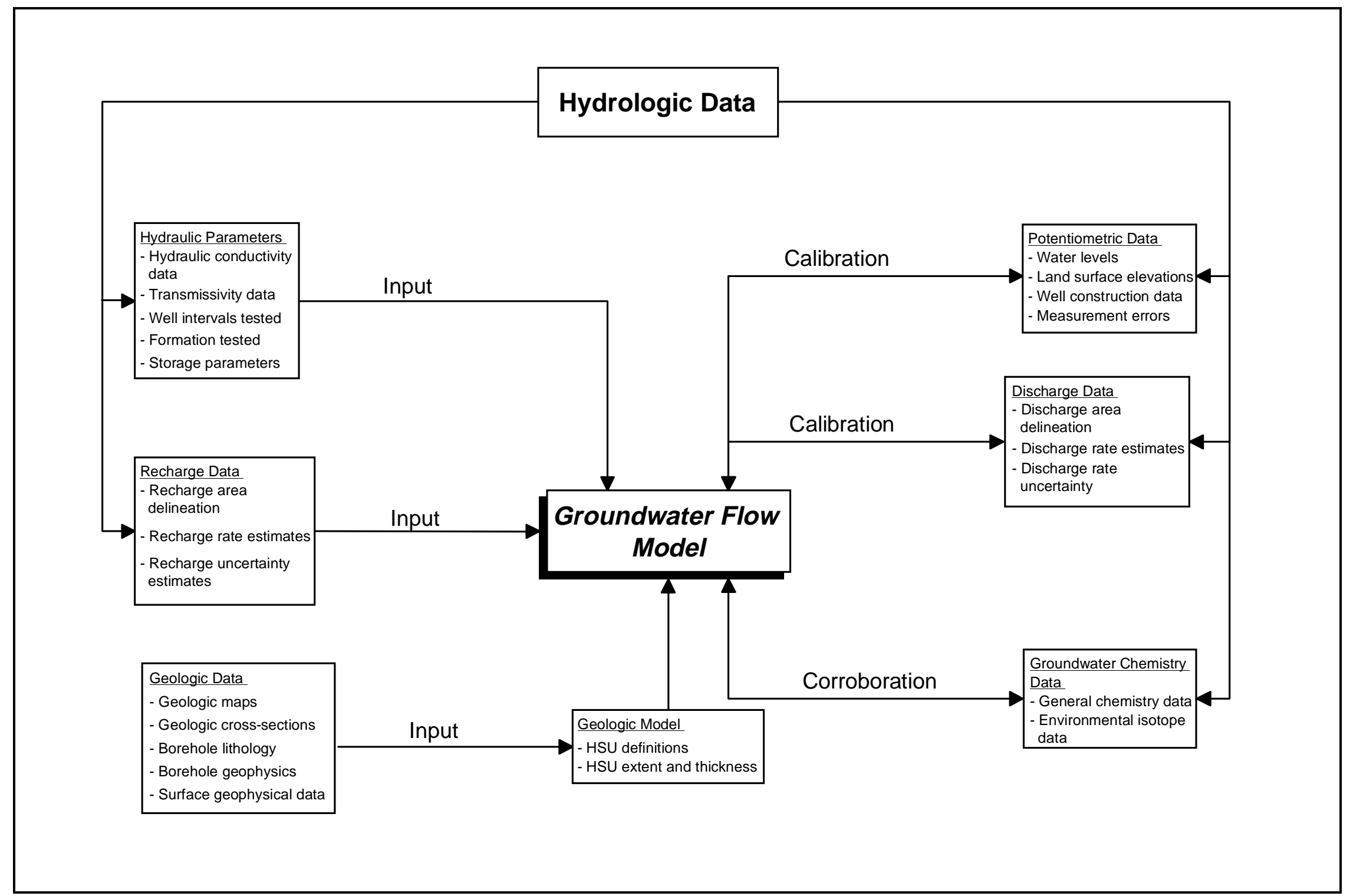

Figure 5-4

Data Types and Utilization in the Groundwater Flow Model 
CAU-scale groundwater flow model. This dataset will include supporting data such as measurement errors, land surface elevations, borehole deviations, groundwater temperature, and well construction information where available.

During the calibration process, input parameters such as recharge and hydraulic conductivity are adjusted until the hydraulic heads calculated by the model match the observed hydraulic heads, within prespecified limits. For the steady-state calibration, a set of observed average hydraulic heads will be determined from the dataset by selecting an appropriate range in which the measurements appear to be stable and approximately consistent with expected prepumping conditions. This is the same process that was followed for the determination of target heads for the regional model calibration (DOE/NV, 1997).

After the steady-state heads are calibrated, additional simulations will be performed to examine transient effects. In the transient simulations, the pumpage from water supply wells will be included if applicable, and hydraulic head changes, with time, will be simulated. The simulated head trends will be compared with the measured head changes over time. This will provide an additional target with which to calibrate the groundwater flow model.

\section{Recharge}

There are two sources of recharge to the Frenchman Flat CAU model. The first source is groundwater flow across the CAU-model boundary from neighboring regions, and the second is recharge from local precipitation. The flux across the CAU-model boundary will be determined from the regional groundwater flow model. The regional groundwater flow model integrates the entire flow system into a mass conservative representation. To determine the boundary fluxes into the Frenchman Flat CAU model domain, the regional geologic model will be updated to include the most recent geologic interpretation for Frenchman Flat. Next, the regional groundwater flow model will be recalibrated with the updated geologic model. This will provide the most up-to-date groundwater flux information for the Frenchman Flat region.

Finally, the areal recharge will be initially defined as in the regional groundwater flow model (DOE/NV, 1997). Refinements to the recharge will be incorporated as they become available. Work ongoing at the DRI is addressing the question of recharge. The DRI is evaluating several 
precipitation estimates to assess the degree of uncertainty in the recharge estimates. In addition, they are measuring ${ }^{36} \mathrm{Cl}$ profiles in numerous soil horizons on the NTS. From these data, they hope to be able to define the spatial distribution of recharge in much greater detail than what is available from the original Maxey-Eakin approach (Maxey and Eakin, 1949) used in the regional groundwater flow model. The DRI has also calculated the recharge through the bottom of several craters (Hokett and Gillespie, 1996; Tyler et al., 1992).

\section{Discharge}

Groundwater discharge occurs as either outflow across the groundwater flow model boundary, discharge to the land surface, or discharge to wells. The flow across the groundwater flow model boundary will be handled via the fluxes determined in the regional groundwater flow model as was described for recharge. There is no known discharge to the land surface within the Frenchman Flat region. There is current or historical discharge to several water supply wells located in Frenchman Flat. This discharge will be included in the transient flow simulations.

\section{Hydraulic Properties}

The hydraulic conductivity of the geologic units is a major control on the movement of groundwater. Hydraulic conductivity values have been measured in numerous wells in and around the NTS. The hydraulic conductivity values will be used in two ways. First, the range of measured values provides an uncertainty range within which the calibrated values should fall. Second, the values will be used during the uncertainty analyses to generate realizations that are as realistic as possible.

In the regional groundwater flow model (DOE/NV, 1997), the calibrated hydraulic conductivity values were shown to fall within the range of measured values. During the CAU model calibration, the hydraulic conductivity data will not be calibrated on a cell-by-cell basis, but rather will be defined on larger zones that represent similar hydrogeologic conditions. Measured conductivity within the zones (which are not yet defined) will be used to bound the range of values.

During the uncertainty analyses, a number of possible hydraulic conductivity fields will be created by DRI to represent possible representations of the heterogeneity. These possible random fields will be conditioned on observed values. This means that where measured values are recorded, the generated 
random field will match the observed value within a specified error range. Further discussion will be presented in Section 5.1.7 of this document.

An additional hydraulic parameter is the storage coefficient. Good storage coefficient data requires that an aquifer test be performed with two wells, one a pumped well and the other an observation well. Few such tests were conducted on the NTS due to the cost of installing the observation well. Several aquifer tests in carbonate rocks away from the NTS also provided good storage coefficient values (Bunch and Harrill, 1984).

\section{Groundwater Geochemical Data}

Groundwater chemistry evolves or changes as groundwater moves through the subsurface environment. Groundwater acquires a general chemical signature or fingerprint by reaction with aquifer solids along the flow path. However, certain constituents (e.g., stable isotopes of hydrogen and oxygen) do not change along the flow path, and therefore, provide information on recharge conditions. Other constituents, such as ${ }^{14} \mathrm{C}$, can be used to estimate the age of groundwater. These data will be assessed to determine if they are useful for providing corroborating information in support of the CAU modeling. Predicted flow paths and contaminant velocity may be compared with geochemical data to determine if the path is consistent with the chemical evolution of the water. Additionally, the ${ }^{14} \mathrm{C}$ data may provide an independent estimate of contaminant velocity including the effects of advection and matrix diffusion.

\subsubsection{Data Assessment for Contaminant Transport Model}

A wide variety of data must be defined to develop a model of contaminant transport in the groundwater flow system. These data include: the source term, effective porosity, radioactive decay coefficients, distribution coefficients, matrix diffusion coefficients, matrix porosity, a description of the fracture geometry and, if necessary, a description of colloid facilitated transport. The data types and their utilization during the modeling process are summarized in Figure 5-5.

\section{Initial Source-Term Conditions}

Two source-term datasets will be defined for the Frenchman Flat CAU. One source term will be based on unclassified data and will be extrapolated from all unclassified CAMBRIC data. Later, a 


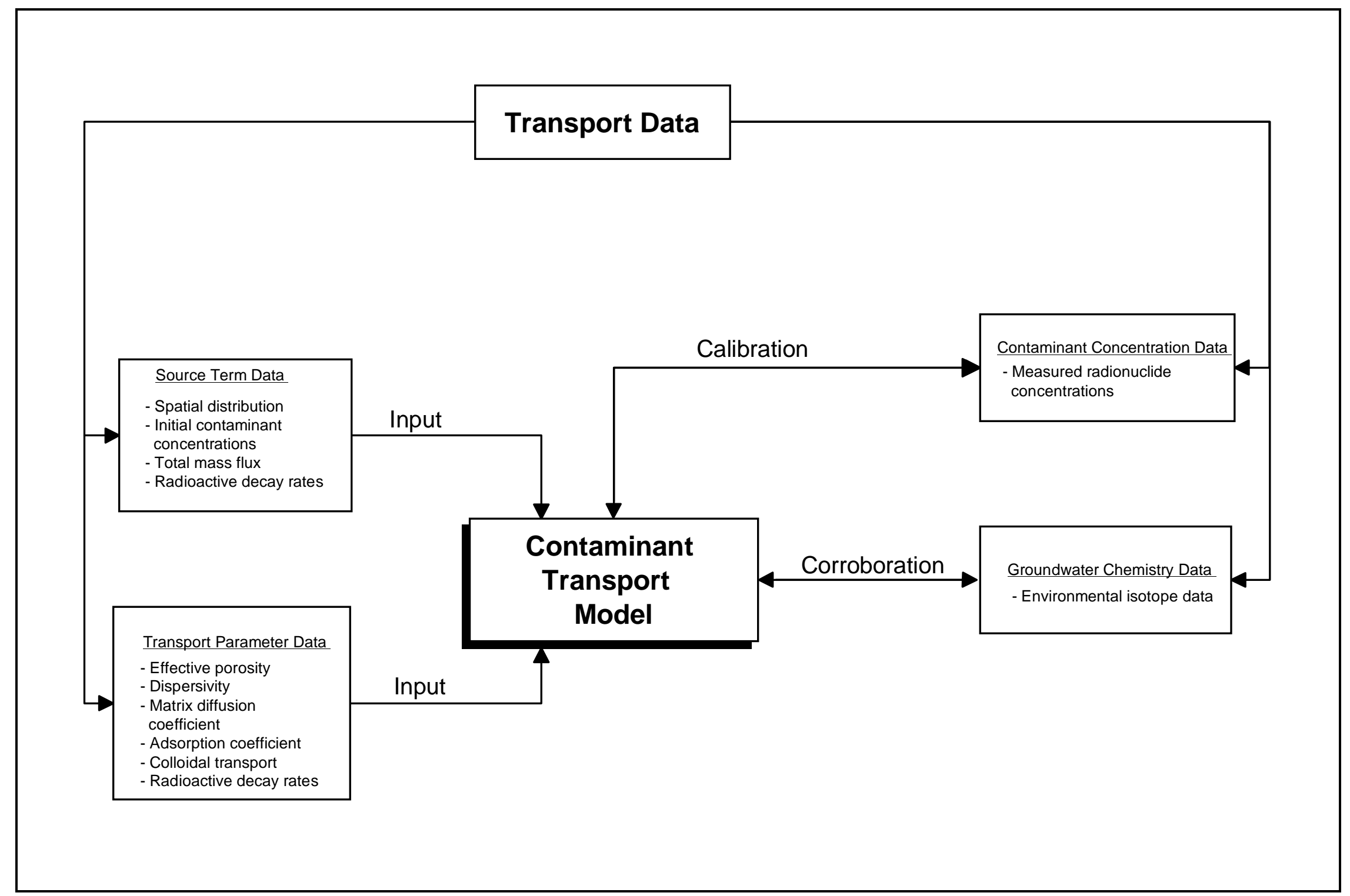

Figure 5-5

Data Types and Utilization in the Contaminant Transport Model 
classified dataset, based on information from individual tests will be used to calculate the final location of the contaminant boundary. For the unclassified data, the initial concentration data will be derived from the work to be conducted by LLNL and described in more detail in Section 5.2.3. Scientists at LLNL will model the release of radionuclides from the CAMBRIC test to provide the flux of radionuclides from the cavity, the puddle glass, and the rubble chimney (source-term model). The release mechanisms will include desorption, glass dissolution, and possible colloid migration. This combination of data will also form the basis for the classified source term that will be assigned to each of the underground test locations in Frenchman Flat.

The scale of the CAU model will be larger than the source-term model. The spatial distribution of contaminants will be integrated in the CAU model to preserve total mass. The release rate from the rubble zone and cavity will be summarized in terms of a total mass flux, again to preserve the total mass exiting the cavity and chimney. This contaminant mass flux will serve as the source term for the transport simulations.

\section{Effective Porosity}

The advection velocity of a contaminant (assuming no chemical or diffusion interactions) is the same as the mean water velocity. The water velocity is defined as the groundwater flux (from the groundwater flow model) divided by the effective porosity, which is a measure of the interconnected pore space through which water and solutes migrate. The effective porosity values for the Frenchman Flat contaminant transport model will come from several sources. First, the data from the CAMBRIC experiment will be of primary importance for providing an effective porosity for the Alluvial Aquifer. For the other HSUs, data from outside of Frenchman Flat will be utilized to establish an appropriate range of values for effective porosity. It is expected that a mean value and uncertainty range will be established. This range of values will be used in the uncertainty analyses described in Section 5.1.7.

\section{Radioactive Decay Coefficients}

For each of the potential radioactive contaminants, radioactive decay coefficients will be defined. These values will be obtained from either LANL or LLNL. These values are known with high precision and will be assumed to be constants for the duration of the transport simulations. 


\section{Distribution Coefficients}

The distribution coefficients for each of the potential contaminants will be obtained from published reports of laboratory experiments. Published distribution coefficient values are typically quite variable (Triay et al., 1993) and therefore have a wide range of uncertainty. For the transport simulations, an expected value for each radionuclide will be chosen from the published ranges. Typically, the expected value will be chosen to be conservative (i.e., closer to the low side of the range of values). Although these values are quite uncertain, it is not expected that this will significantly impact the predicted contaminant boundary location. As observed in the Frenchman Flat VOIA (IT, 1997c), the location of the maximum extent of the contaminant boundary over a period of 1,000 years was dominated by the most mobile radionuclides. Unless the sorbed radionuclides have a distribution coefficient near zero, they will lag behind the more mobile radionuclides. As a result, the sorbed radionuclides are not expected to impact the location of the maximum extent of the contaminant boundary.

\section{Matrix Diffusion Coefficients}

Based on the regional transport modeling (DOE/NV, 1997) and the VOIA (IT,1997c), it is expected that matrix diffusion will be an important mechanism controlling the rate of radionuclide migration in fractured units and, therefore, may influence the location of the contaminant boundary. The matrix diffusion coefficient controls, in part, the rate at which a contaminant will diffuse from a fracture into the surrounding rock matrix. All things being equal, the faster the diffusion, the slower the contaminant will appear to move relative to the movement of groundwater. Matrix diffusion coefficient estimates will be available from literature sources. These may include field and laboratory experiments at Yucca Mountain and from other sites. There are no matrix diffusion measurements from Frenchman Flat. The diffusion coefficients available from the literature will be evaluated to assess the range of uncertainty in the matrix diffusion coefficient value.

\section{Matrix Porosity}

The matrix porosity defines the volume of water in the matrix into which contaminants can diffuse. The larger the volume, the more contaminant that can diffuse into the matrix and be stored there. Matrix porosity values are available for the shallow Tertiary volcanic units of Frenchman Flat. Much 
of these data are available from core and geophysical logs. The matrix porosity values are uncertain, but the range is typically much smaller than for many of the other parameters. Matrix porosity will be included in the uncertainty analyses, but it is not expected to be one of the dominant parameters.

\section{Fracture Geometry}

For units such as the welded tuffs or the carbonate aquifer, the description of the fracture geometry, the spacing, orientation, and fracture aperture all factor into the estimate of matrix diffusion. Much of the fracture spacing and orientation information comes from the study of core (BN, 1997). The uncertainty in these values will be estimated from the available analyses. The fracture spacing is a parameter that controls, in part, the rate of diffusion into the matrix (IT, 1996f). The fracture orientation has been used in the past to correct the spacing values measured in vertical boreholes. The fracture aperture is not readily measurable from core or geophysical logs. One method of calculating an effective aperture is via the cubic law, as was done in the VOIA (IT, 1997c). Another method is to use fracture porosity data from geotechnical studies and to convert these to aperture with a planar fracture assumption. The difficulty will be the nonuniqueness of the value. The effective porosity of a fractured geologic unit made up of planar fractures is a function of the aperture and the spacing. Assumptions regarding the spacing and the appropriateness of a planar fracture model will limit the accuracy of a calculation of fracture aperture.

\section{Colloid-Facilitated Transport}

The transport of contaminants via colloids is an important consideration. In previous discussions of the regional model (DOE/NV, 1997), it was stated that sorbing nuclides are not likely to impact the determination of the location of the contaminant boundary because they will travel at a slower rate than nonsorbing nuclides. If these sorbing contaminants attach to colloidal-size particles, they can be transported much more rapidly than would otherwise be expected. An ongoing research project jointly being conducted by LLNL, LANL, and the DRI is addressing the question of how to model colloid-facilitated transport in fractured volcanic rocks on Pahute Mesa. That research will not be available in time to provide much insight into colloid transport in Frenchman Flat. However, that may not be a significant complication. Colloid transport in Frenchman Flat may occur in some of the fractured volcanic units and the carbonate aquifer. The working points of all but one underground test in Frenchman Flat were in the Alluvial Aquifer. Unless the radionuclides migrate to a fractured 
unit such as a welded tuff or carbonate, the issue of colloid transport will not be very important. If transport in fractured units becomes important, then an approach to simulate colloid transport may need to be developed.

\subsubsection{Code Selection}

The selection of the code to use for the CAU simulations is an important decision. The selected code must be capable of simulating the characteristics of the physical and chemical hydrogeologic system, as identified in the conceptual model to the degree required to meet the objectives. In addition, only codes that have been thoroughly evaluated through a rigorous quality assurance process, including code verification, will be considered in the code selection process. Code verification is defined as the process of ensuring that the code algorithms are operating properly. Typically, code verification is accomplished by comparing the model output to analytical solutions and in some cases results of other numerical models.

The selection process will ensure that the CAU model will simulate the migration of the potential contaminants in groundwater and allow for an assessment of the uncertainty in the predictions. To establish confidence in the CAU model, the process to select the code will be outlined and justified. The selection process begins with the identification of a set of desired code attributes, followed by the identification of candidate codes and a preliminary selection of the best-qualified codes. These codes are then tested before the final code selection is made.

\subsubsection{Code Attributes}

A number of desired code attributes, or capabilities, were defined to satisfy the three modeling objectives stated in Section 5.1.2. The first objective requires the CAU model to have the ability to represent the important physical and chemical features of the CAU groundwater flow system. The features will include faulting, stratigraphy, sources and sinks of water, the distribution of contaminants and their rates of introduction into the groundwater flow system, and other physical or chemical features unique to the CAU. The second objective requires the CAU model to simulate the movement of a variety of contaminants; the distribution and abundance of the contaminants serve to define the contaminant boundary. The third objective requires flexibility in the CAU model to allow grid changes, placement of additional wells, and boundary condition variations. The code attributes that were defined consistently with the three modeling objectives were categorized under "general," 
"flow model," and "transport model" (Figure 5-2). Each of these attributes are described and assessed with respect to importance for the CAU modeling.

Table 5-2

Desired Hydrologic Code Attributes

\begin{tabular}{||l|l|l||}
\hline \multicolumn{1}{|c|}{ General Attributes } & Flow Model Attributes & Transport Model Attributes \\
\hline \hline - Fully three-dimensional & - Saturated groundwater flow & $\begin{array}{l}\text { - Advection, dispersion, adsorption, } \\
\text { and matrix diffusion } \\
\text { nodes (100,000 or more) }\end{array}$ \\
- Established pre- and postprocessors & $\begin{array}{l}\text { - Heterogeneous and anisotropic } \\
\text { hydraulic conductivity }\end{array}$ & $\begin{array}{l}\text { - Radioactive decay, daughter } \\
\text { products }\end{array}$ \\
- Steady-state and transient capability & $\begin{array}{l}\text { and sinks of water } \\
\text { - Ability to accept multiple datasets for }\end{array}$ & - Temperature dependence \\
Monte Carlo simulations & - Ability to simulate complex & - Acceptable numerical accuracy \\
- Efficient solver & geology & - Transport of colloids \\
\hline
\end{tabular}

\section{General Attributes}

The general attributes are defined with the goal of using a code that can closely represent a large modeling domain, in addition to being flexible, user friendly, and efficient. These attributes are discussed in the following paragraphs.

Fully Three-Dimensional: The groundwater flow system is controlled by the distribution of geologic units as well as the location of sources and sinks of water. Additionally, transport properties including source location and strength, porosity, and diffusion may vary in space. The three-dimensional nature of the groundwater system requires that the CAU model will also need to be three-dimensional to adequately simulate migration of the potential contaminants within the CAU model area.

Capable of Simulating Large Numbers of Nodes: The greater the number of nodes in the CAU model, the greater the detail that can be included. Given the anticipated large geographic area of the Frenchman Flat CAU model, the ability of the CAU model to simulate many nodes will control the 
amount of detail that can be included. In general, each of the selected codes will only be limited by the capacity of the hardware, not by an internal software limitation.

Established Pre- and Postprocessors: The task of creating the input datasets for any model is simplified by having preprocessors setup the input data into a form that is required by the model. Postprocessors take model output and typically create graphic images of some simulated parameter such as water level or solute concentration. Pre- and postprocessors generally speed up the modeling task. If the processors are not available, then the appropriate processors would be developed.

Steady-State and Transient Capability: The initial flow simulations for the CAU model will be steady-state with possible subsequent transient runs to further refine the groundwater flow model. The contaminant transport simulations will all be performed under transient conditions. Some of the codes do not include a steady flow option, but rather reach steady-state by leaving parameters fixed and performing transient simulations over long periods of time until steady-state is reached. This approach is adequate, but somewhat slower than if a true steady-state option were available.

Ability to Accept Multiple Datasets for Monte Carlo Simulations: A key aspect of the CAU model will be an assessment of the amount of uncertainty in the predictions. One approach suitable for assessing uncertainty is the Monte Carlo method. In a Monte Carlo simulation, parameters are varied within specified limits defined by probability distributions. This code-selection attribute requires that the selected code has the ability to accept datasets generated either internal or external to the program.

Efficient Solver: To simulate in sufficient detail, the CAU models will require a large number of nodes as mentioned above. To make these large CAU models practical, the models must run efficiently. The solvers must be efficient enough to allow for more than one run per day. A code that requires more than six hours per simulation would be eliminated. A maximum six-hour run time allows two runs per day on a single computer.

\section{Groundwater Flow Model Attributes}

The attributes for the groundwater flow model are defined with the goal of simulating the flow paths and fluxes. 
Saturated Groundwater Flow: The focus of this CAI is solely on the saturated zone. Although many of these codes will simulate variably saturated conditions, the codes must also be able to simulate saturated conditions as well.

Heterogeneous and Anisotropic Hydraulic Conductivity: Aquifer heterogeneity reflects the natural variability in the subsurface. The code must be capable of simulating flow through aquifers in which the hydraulic conductivity may vary from location to location. Anisotropy is a directional dependence of the hydraulic conductivity. In fractured aquifers, it is common for hydraulic conductivity to be larger in a direction parallel to fracturing and smaller perpendicular to fracturing.

Point and Distributed Sources and Sinks of Water: Recharge may occur over a large spatial area due to precipitation, or may be concentrated into washes or craters. Discharge may occur at wells or individual springs, or may occur over larger areas such as playas. The code should have the capability to simulate these various cases.

Temperature Dependence: The flow of groundwater may be influenced by water temperature variations. Warm water is more buoyant than colder water and tends to rise. Additionally, warm water is less viscous and tends to move more easily than cold water. The effects of temperature are expected to be minimal in Frenchman Flat, particularly in the shallow groundwater flow system.

Ability to Simulate Complex Geology: As described in Section 3.4, the geology of Frenchman Flat is very complex. It consists of multiple stratigraphic units, some of which are truncated by faults and other structural features. Even within units, facies changes result in spatial variations in material properties. The flow of groundwater (amount and direction) is governed in large part by the distribution of geologic units. The code must be able to include important features of the geology such as lateral and vertical changes in material properties. Much of this attribute is similar to earlier general attributes related to number of grid nodes and simulation speed. The greater the number of nodes, the more detail that can be incorporated into the groundwater flow model.

\section{Transport Model Attributes}

The contaminant transport model portion defines the attributes that will be necessary to simulate the migration of potential contaminants including radionuclides. 
Advection, Dispersion, Adsorption, Porosity, and Matrix Diffusion: The primary processes of interest in Frenchman Flat that are expected to influence the concentration of radionuclides in groundwater are listed here. The regional contaminant transport model (DOE/NV, 1997) simulations and the VOIA (IT, 1997c) showed that advection (via the groundwater flux) and matrix diffusion were the primary factors influencing tritium transport. Porosity is important because it directly influences the solute velocity in the aquifer. It is expected that adsorption will also be important for reactive contaminants. Dispersion was not shown to be of primary importance in the regional simulations, but is included here because it may be more important at smaller scales.

Radioactive Decay, Daughter Products: All but one of the identified potential contaminants of interest are radionuclides. The concentration of radionuclides decreases with time via the process of radioactive decay. A radionuclide may decay into another radionuclide (called a daughter product) or into a stable element. The code should be capable of simulating the decay of a radionuclide and its daughter product(s).

Acceptable Numerical Accuracy - Ability to Reproduce Analytical Solutions: The numerical solution of the transport equation is typically more difficult than the solution of the flow equation. This attribute requires the results of the code for a given test problem to have been checked against analytical solutions and also against the results of other numerical models for the same problem. Documentation of this quality assurance checking must be available.

Transport of Colloids: The movement of colloids may enhance the movement of otherwise immobile contaminants. Colloids are submicron-size particles to which radionuclides or other solutes sorb. The colloids are transported by groundwater flow and the sorbed solutes move with the colloids. Most groundwater solute transport codes do not explicitly simulate the transport of colloids. This attribute selects a code for which colloid transport is included as an option. Colloid transport is expected to be a more important issue for fractured units such as the Lower Carbonate Aquifer than for porous units like the Alluvial Aquifer. 


\subsubsection{Code Identification and Preliminary Selection}

An initial list of ten available numerical codes capable of simulating three-dimensional groundwater flow and transport was compiled and presented in the UGTA modeling approach document (IT, 1998). The list includes the following codes:

- MODFLOWT (Duffield et al., 1996)

- CFEST (Gupta, 1996)

- $\quad$ SWIFT-III (Ward, 1990)

- PORFLOW (Runchal and Sagar, 1992)

- BIOF\&T-3D (Katyal, 1995)

- PARFLOW (Ashby et al., 1996)

- GANDT (Sorenson, 1997)

- FEHM (Zyvoloski et al., 1997a)

- TRACR3D (Travis and Birdsell, 1991)

- NUFT (Nitao, 1995).

Of this initial list, three codes were selected for testing to ensure compliance with requirements of the Frenchman Flat CAU model goals. The three codes selected for testing were FEHM, TRACR3D, and SWIFT III.

The FEHM code uses a finite-element formulation of the governing flow and solute transport equations and also includes a particle tracking solution (Robinson et al., 1995). The code was developed at LANL and is documented in the Users Manual (Zyvoloski et al., 1997a), the Verification and Validation Report (Dash et al., 1996), and a Models and Methods Summary (Zyvoloski et al., 1997b). FEHM is a comprehensive flow, heat, and solute-transport simulator that can be used for two- or three-dimensional multiphase applications. The many capabilities of the code can be identified by the many submodels that make up the overall transport model. From Zyvoloski et al. (1997a), the flow and energy transport equations for simulating processes within porous and permeable media include: (1) heat and mass transfer with pressure- and temperature-dependent properties; (2) relative permeabilities and capillary pressures; (3) isothermal air-water transport; and (4) heat and mass transfer with noncondensible gas.

The code also has capabilities to simulate dual porosity and double porosity/double permeability flow and transport for problems dominated by fracture flow. The reactive transport submodel simulates transport of multiple solutes with chemical reaction and includes a particle tracking option. Finally, 
constitutive relationships for pressure- and temperature-dependent fluid/air/gas properties, stress dependencies, and reactive and sorbing solutes are also included.

The TRACR3D code was also developed at LANL. Documentation of the code is provided by Travis and Birdsell (1991). The code simulates time-dependent mass flow and chemical species transport in three-dimensional, deformable, heterogeneous, and sorptive porous media. The code uses a finite-difference formulation and includes radioactive decay. The code simulates a variety of flow conditions including steady or transient, one-, two-, or three-dimensional geometry, and will accommodate both saturated and unsaturated flow. Several key features are missing from TRACR3D such as temperature dependence and dual porosity capability for fractured media. On the other hand, the code includes several unique and potentially useful features that other codes to not consider. A nonlinear momentum equation allows TRACR3D to be used for higher Reynolds number flow regimes where the classical linear form of Darcy's law may not be valid. Additionally, the code uses several approaches to more efficiently simulate high Peclet number transport problems. Typically, a high Peclet number requires a small grid spacing, which increases computer run times, or upstream weighting schemes but usually at the cost of numerical dispersion. TRACR3D employs several schemes to remove excess numerical dispersion and thus, allow the use of larger grid sizes.

The SWIFT (Sandia Waste Isolation Flow and Transport) computer code (Reeves et al., 1986a and b; Ward et al., 1984; Ward, 1990) is a 3-D groundwater flow and transport code that simulates the movement of solutes, including radionuclides, in groundwater. The code is finite-difference and includes fluid flow, heat transfer, and brine transport in saturated porous media. SWIFT evolved from the USGS code SWIP (Survey Waste Injection Program) (USGS, 1976) and has undergone several modifications since its inception. SWIFT III (Ward, 1990) can simulate steady-state or transient coupled three-dimensional fluid flow, heat transfer, brine transport, and radionuclide chains in saturated porous and fractured media. The transport of radionuclides in fractured media includes a dual porosity/dual permeability option that allows for diffusion into and out of the rock matrix.

\subsubsection{Code Testing and Final Code Selection Process}

Five criteria were established to evaluate the three selected codes. The final code selection was based on these criteria. These code-testing criteria are portability, level of quality assurance testing, user-friendliness, ability to represent the CAU hydrogeology, and speed of simulation. 


\section{Testing Criteria}

The criteria that were used to assess the codes during testing are described below. These range from a somewhat subjective assessment of ease of use to more quantifiable assessments such as the run time for a sample problem. The testing criteria are as follows:

Portability: The CAU model will be sent to independent reviewers as well as the State of Nevada. Each of these stakeholders may want to run the code themselves. Therefore, the code should be usable without requiring any special equipment or software. Additionally, the CAU model will likely need to be run on a classified computer in the DOE Nevada Support Facility to produce a final estimate of the contaminant boundary. The computer available for those runs will most likely be a Pentium-based personal computer (PC). The code and associated preprocessors and postprocessor must be PC-based to allow for efficient classified simulations.

Quality Assurance Evaluation: The selected code must have been extensively verified to ensure that the output is accurate. The quality assurance evaluation refers to the level of documentation and testing for a code. The ability of the code to simulate the processes of interest is a function of the formulation of the equations and the quality of the programming. A code that has been thoroughly checked will have been verified against other codes as well as having been compared with analytical solutions. These comparisons must be documented before a code will be used for the Frenchman Flat simulations.

Ease of Use: The ease of use is a subjective judgment that assesses the degree of difficulty that modelers encounter when using the code. This is by necessity a value judgment of the modelers and reflects their experience and background. A great deal of energy is usually spent calibrating the model and later setting up the sensitivity and uncertainty analyses. A code that is difficult to use makes the job of calibration more difficult and reduces the code's portability. Ease of use includes factors such as the structure of the input datasets and the units of measure used in the code.

Ability to Represent the CAU Hydrogeology: The primary geologic features that control groundwater flow need to be represented in the CAU model. These features include the hydrostratigraphy, boundaries, and structural features such as faults. In addition, the ability to model 
physical processes of concern, advection, dispersion, dual porosity, adsorption, and radioactive decay, is also important.

Speed of Simulation: The time required to get a solution is also of importance to the evaluation of the codes. The faster the code, the shorter the time to complete each model run. As calibration normally requires many (often times greater than 100) model runs, the simulation time becomes a problem, if it is too long. For the purposes of the CAU model, simulation times in excess of six hours for a steady-state flow simulation are unacceptable when running on a computer comparable to a Pentium Pro 200. This maximum length of simulation time will allow for two or three runs per day, which means 35 to 50 days to perform the calibration.

\section{Test Problem}

A test problem was created to evaluate the three codes. The features of the test problem were chosen to mimic the Frenchman Flat CAU model. By doing so, the effort to set up and run the problem could be evaluated, and the run times of the code could be assessed.

The test problem was designed to mimic the expected level of complexity anticipated for Frenchman Flat. A portion of the Frenchman Flat CAU geologic model, $9 \mathrm{~km}$ (5.6 mi) by $9 \mathrm{~km}(5.6 \mathrm{mi})$ by $1,950 \mathrm{~m}(6,400 \mathrm{ft})$ in depth, was selected for the comparison (Figure 5-6). The test problem boundary conditions consisted of a constant-head source on the west and east, with no flow boundaries on the north and south. The geologic model included seven hydrostratigraphic layers as well as several dipping faults. For the FEHM simulations, the finite-element mesh was created to honor the stratigraphic contacts and the dipping faults. Each of the HSUs was assigned a unique hydraulic conductivity consistent with values obtained from the regional flow model (DOE/NV, 1997). The finite-difference codes (TRACR3D and SWIFT) used a uniform grid in the horizontal direction and variable spacing in the vertical direction to represent layers. An approximation to the geologic model that included vertical faults was suggested to support the finite-difference approach. If nonvertical faults are assumed, then the location of a fault shifts in plan view, for various layers. To utilize the finite-difference grid of SWIFT, the faults in the example problem were approximated as vertical. In Frenchman Flat, the use of vertical faults does not appear to be a serious limitation. 


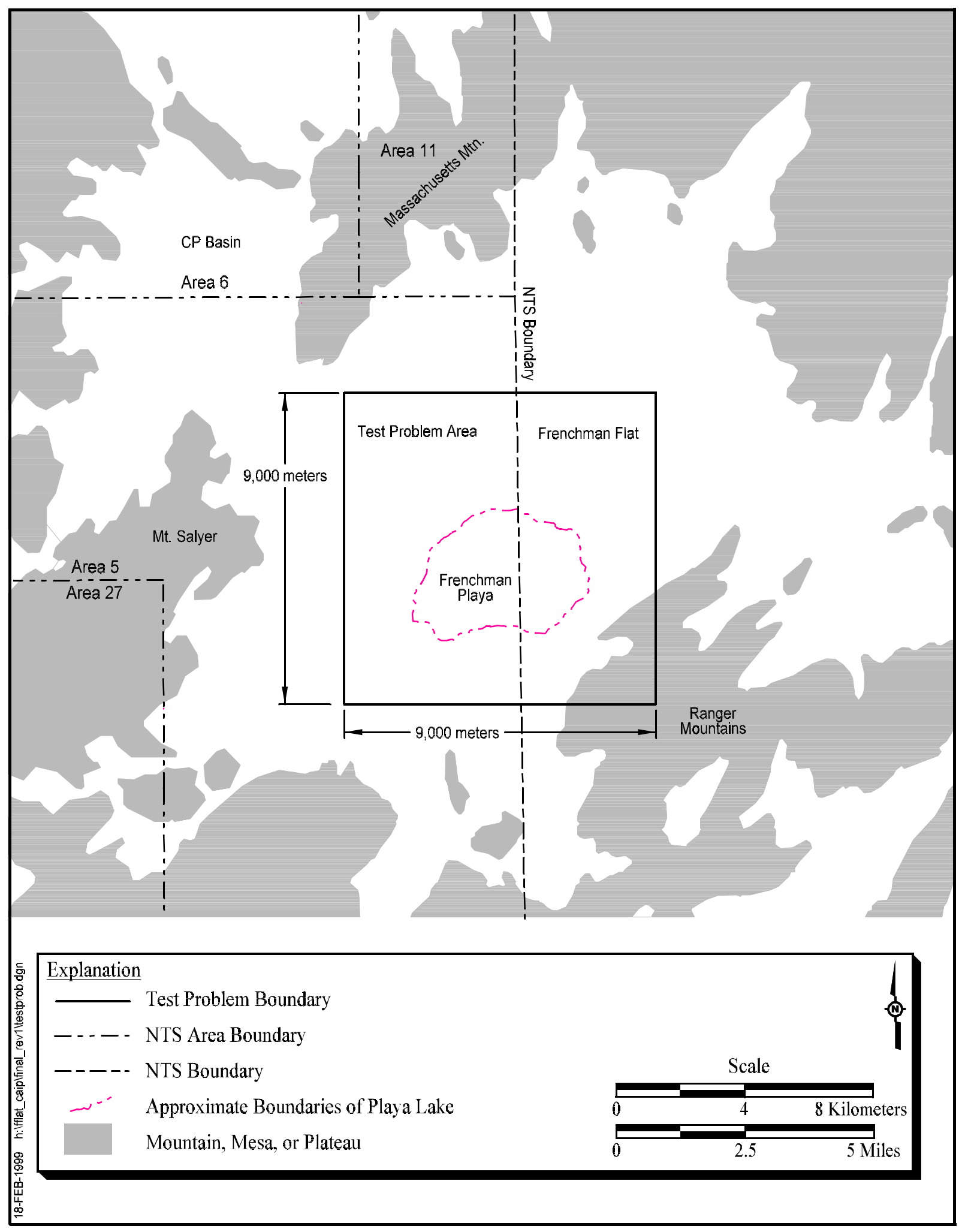

Figure 5-6 Area of Frenchman Flat Test Problem 


\subsubsection{Comparison of the Candidate Codes}

An initial comparison of the three codes with respect to the attributes discussed in Section 5.1.4.1 was presented as part of the modeling approach document (IT, 1998). Those comparisons have been updated and are presented in Table 5-3 where the attributes have been grouped into categories of "general", "flow model", and "transport model".

From Table 5-3, it is seen that FEHM and SWIFT have similar capabilities. There are some deficiencies in TRACR3D, but it is included in the evaluation because of several possible advantages to TRACR3D for high Peclet number and Reynolds number simulations. It should

be noted that none of the codes has the explicit capability to simulate the transport of colloidal size particles. If colloid transport becomes an important issue in Frenchman Flat, approaches will be developed to utilize the chosen code to approximate colloid transport.

The comparison of the three prospective codes with respect to the attributes listed in Table 5-3 clearly shows that FEHM and SWIFT provide a better approximation to the hydrogeologic features in Frenchman Flat. The missing temperature dependence and matrix diffusion features of TRACR3D make it a less desirable code.

An evaluation of each of the three codes with respect to the five testing criteria discussed in Section 5.1.4.3 is presented in the following text. This evaluation provides the basis for the final code selection.

\section{Portability}

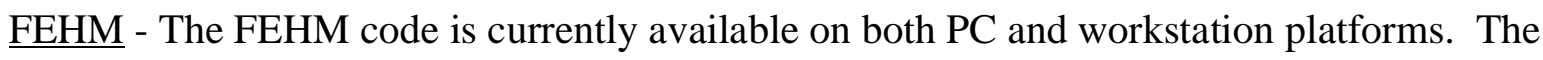
code requires a finite-element mesh generator to be useful. A standard and a more sophisticated irregular mesh generator are both available at LANL, but both require a UNIX work station to run. The standard mesh is an improvement over a finite-difference grid in that it creates an irregular finite-element mesh in plan view, but repeats that mesh for all layers. The standard mesh fails to utilize the finite-element grid flexibility to its full extent especially in the vertical direction. The irregular mesh generator is better at representing features such as faults, but is more complicated to implement. Other mesh generators that run on a PC may be able to create FEHM input files, but this option was not pursued because it was believed that it would have taken more development time than was available. 
Table 5-3

Compilation of Code Attributes

\begin{tabular}{|c|c|c|c|}
\hline Code Attribute & FEHM & TRACR3D & SWIFT \\
\hline \multicolumn{4}{|l|}{ General } \\
\hline Fully three-dimensional & $\mathrm{Y}$ & $\mathrm{Y}$ & $\mathrm{Y}$ \\
\hline Greater than 100,000 nodes & $\mathrm{Y}$ & Y & $\mathrm{Y}$ \\
\hline Pre- and postprocessors & $\mathrm{Y}$ & $\mathrm{Y}$ & $\mathrm{Y}$ \\
\hline Steady-state capability & $\mathrm{Y}$ & $\mathrm{Y}$ & $\mathrm{Y}$ \\
\hline Transient capability & $\mathrm{Y}$ & Y & $\mathrm{Y}$ \\
\hline Accept multiple datasets for Monte Carlo & $\mathrm{Y}$ & Y & Y \\
\hline Efficient Solver & $\mathrm{Y}$ & $\mathrm{Y}$ & $\mathrm{Y}$ \\
\hline \multicolumn{4}{|l|}{ Flow Model } \\
\hline Saturated groundwater flow & $\mathrm{Y}$ & $\mathrm{Y}$ & $\mathrm{Y}$ \\
\hline Heterogeneous hydraulic conductivity & $\mathrm{Y}$ & $\mathrm{Y}$ & $\mathrm{Y}$ \\
\hline Anisotropic hydraulic conductivity & $\mathrm{Y}$ & $\mathrm{Y}$ & $\mathrm{Y}$ \\
\hline Sources and sinks of water & $\mathrm{Y}$ & Y & Y \\
\hline Temperature dependence & $\mathrm{Y}$ & $\mathrm{N}$ & $\mathrm{Y}$ \\
\hline Ability to incorporate complex geology & Y & $\mathrm{Y}$ & Y \\
\hline \multicolumn{4}{|l|}{ Transport Model } \\
\hline Advection & $\mathrm{Y}$ & $\mathrm{Y}$ & $\mathrm{Y}$ \\
\hline Dispersion & $\mathrm{Y}$ & $\mathrm{Y}$ & $\mathrm{Y}$ \\
\hline Adsorption & $\mathrm{Y}$ & $\mathrm{Y}$ & $\mathrm{Y}$ \\
\hline Matrix Diffusion & $\mathrm{Y}$ & $\mathrm{N}$ & $\mathrm{Y}$ \\
\hline Radioactive Decay & $\mathrm{Y}$ & $\mathrm{Y}$ & $\mathrm{Y}$ \\
\hline Daughter Products & $\mathrm{Y}$ & $\mathrm{Y}$ & $\mathrm{Y}$ \\
\hline Temperature dependence & $\mathrm{Y}$ & $\mathrm{N}$ & $\mathrm{Y}$ \\
\hline Accurate numerical solution & $\mathrm{Y}$ & $\mathrm{Y}$ & $\mathrm{Y}$ \\
\hline Ability to simulate colloid transport & $\mathrm{N}$ & $\mathrm{N}$ & $\mathrm{N}$ \\
\hline
\end{tabular}

$\mathrm{N}=\mathrm{No}$

$\mathrm{Y}=\mathrm{Yes}$ 
A second issue is the amount of memory necessary to run FEHM. A steady-state flow simulation with just under 50,000 elements was created for the test problem. This required approximately 330 megabytes of random access memory to execute properly. A larger problem and the inclusion of transport would require a greater amount of memory. This is not necessarily a restriction, but would require a very high-end PC.

In summary, the FEHM code is one of the most sophisticated groundwater flow and transport codes available. That sophistication requires a high-level of computing power. A number of the preprocessors and postprocessors are currently available on a UNIX workstation platform because of the superior computing power of those machines. Unfortunately this creates a lack of portability to the modelers in the IT office, the DOE, and most of the stakeholders. It is expected that over the next several years, PCs will advance to the stage that the FEHM level of sophistication will be able to be implemented on the PC. Unfortunately, it is unlikely that the required PC computing power will be available for the Frenchman Flat CAU modeling.

TRACR3D - The TRACR3D code is currently running on a PC platform. However, several preprocessor and postprocessor codes would need to be written to facilitate the usage of TRACR3D. The additional amount of coding is not expected to be excessive and no inherent difficulties that would prevent the use of TRACR3D on a PC were identified.

SWIFT - The SWIFT code runs on a variety of platforms, including a PC. It is not expected that significant difficulty will be encountered in running SWIFT on a PC. For instance, the example steady-state flow problem created for Frenchman Flat has 113,000 cells. This test model required approximately 70 megabytes of memory to run. This is well within the constraints of many PCs on the market today.

\section{Quality Assurance Evaluation}

FEHM - The FEHM code has been tested extensively as part of the Yucca Mountain Project. The checking of the code has been documented in Zyvoloski et al., (1997a), Zyvoloski et al., (1997b), and Dash et al., (1996). Additional testing of the code is provided in Reeves et al. (1994).

TRACR3D - The TRACR3D code is older than the FEHM code and has gone through significant changes over time. The verification of the code, through a series of sample problems, is currently documented in Travis and Birdsell (1991). Additional testing of the code is provided in Reeves et al. (1994).

SWIFT - The SWIFT code has gone through a series of enhancements over the past 20 years or so. The version being proposed is a PC-version developed by HSI GeoTrans, Inc. SWIFT has undergone extensive testing and verification. Several reports describe the testing of the code, including Reeves et al. (1986a) and Ward et al. (1984). 


\section{Ease of Use}

FEHM - For a large code, FEHM does not appear to be dramatically more or less difficult to use compared with other large codes. One difficulty encountered was the generation of a mesh that would accommodate the stratigraphy and the faults. The LANL has an exceptional mesh generator (GEOMESH) (Gable et al., 1995) that can be used to represent the stratigraphy very well. However, a significant amount of difficulty was encountered while trying to create a mesh that also reproduced faults. The inclusion of the dipping faults in Frenchman Flat presented a series of challenges that were not completely solved at the time. It is expected that these difficulties will be solved in the future.

- $\quad$ TRACR3D - For modelers familiar with typical groundwater simulation software, TRACR3D presented several challenges. First, the units in TRACR3D are in centimeters grams seconds units. Therefore, permeability is given in Darcy's or square centimeters $\left(\mathrm{cm}^{2}\right)$, fluid pressure is given in dynes $/ \mathrm{cm}^{2}$, and other parameter units are unfamiliar. This is not a significant problem in most cases because parameter conversions can be included in preprocessing codes, but this will add more work to the development of preprocessing and postprocessing codes.

- Another difficulty is the zone structure for aquifer parameters. The code requires that many material properties describe a single zone. An advantage of this approach is that it simplifies the definition of regions that have the same material properties. However, for a heterogeneous formation, each cell may present a different zone. This creates a more difficult data input structure because it requires a repetition of many parameter values.

SWIFT - The comparison to SWIFT cannot be made objectively because of the modelers' familiarity with the code. It is expected that an unfamiliar user would also have difficulty with the SWIFT data inputs. As with any large, sophisticated code, there is a learning curve that requires the modeler to struggle to learn a code, its quirks, and limitations. Given the limited time frame within which to finish the Frenchman Flat CAU model, it is expected that the SWIFT code will be the easiest for the modelers to use. This is merely a recognition of the experience the modeling team has with SWIFT and does not suggest that SWIFT is an inherently "simpler" code to use.

SWIFT also uses a zone structure for aquifer parameters. However, unlike TRACR3D, SWIFT has an option to create binary input files from an external code that can be read in as individual parameters, thereby reducing the unnecessary duplication of parameter values.

\section{Ability to Represent Frenchman Flat Hydrogeology}

FEHM - The finite element formulation of the FEHM code offers several advantages for representing the physiographic and structural features of Frenchman Flat. The finite elements can be placed along stratigraphic contacts, faults, and facies changes to better represent the subsurface features. The Geoanalysis group at LANL has created several element meshes representing the Frenchman Flat geologic model. At the time of this writing, the meshes represented the stratigraphic contacts very well, but were less successful at reproducing the 
faults. It is expected that with additional time and effort, the faults could also be represented well.

A second alternative is to make all the faults vertical, which should simplify the creation of the finite element mesh. This is an approach that will be implemented in the Frenchman Flat CAU model. The modifications to the geologic model to include vertical faults were made after the FEHM runs were completed. Therefore, the vertical fault approach was not included in the FEHM simulation.

All other aspects of the Frenchman Flat hydrogeology, advection, dispersion, possible temperature dependence, radionuclide decay and daughter products, adsorption, and dual porosity/dual permeability are included in the FEHM code. The dual porosity formulation approximates the one-dimensional process of diffusion into the matrix by a one-dimensional analytical solution to an infinite matrix block. The analytical solution incorporates an effective diffusion coefficient and retardation (via sorption) in the matrix. As long as the diffusion time to the center line of the matrix block is less than the simulation time, the approximation is valid.

TRACR3D - As a finite difference code, TRACR3D has some disadvantages in representing physiographic features with a rectangular grid network. This is not a severe limitation, but complicates the process of including faults and generally leads to a greater number of nodes for a given problem than for a corresponding finite-element solution. Typically, finite-difference equations can be solved more efficiently than finite element equations. This means that simulation times are comparable even with a greater number of finite difference nodes.

A unique feature of TRACR3D is the inclusion of a higher order velocity term in the momentum equation. The inclusion of this term allows the code to be used to simulate flow in situations where the Darcy equation is not valid. Bear (1979) summarized the range of validity of Darcy's law and showed that a significant deviation from linear behavior occurs for a Reynolds number for flow through porous media greater than a value between 1 and 10 . The second order momentum equation in TRACR3D allows for Reynolds numbers up to about 100. Bear (1972) defines the Reynolds number for flow through porous media as:

$$
\operatorname{Re}=\frac{q d}{\mu}
$$

Where:

$\mathrm{q}=$ specific discharge (cubic meters per day $\left[\mathrm{m}^{3} / \mathrm{d}\right]$ )

$\mathrm{d}=$ some length dimension of the porous media, often a grain size measure $(\mathrm{m})$

$\mu=$ kinematic viscosity (square meters per day $\left[\mathrm{m}^{2} / \mathrm{d}\right]$ ). 
Using parameter values representative of the alluvium in Frenchman Flat: hydraulic conductivity $=10 \mathrm{~m} / \mathrm{d}(33 \mathrm{ft} / \mathrm{d})$, hydraulic gradient $=0.003$, grain size $=0.001 \mathrm{~m}(0.003 \mathrm{ft})$, kinematic viscosity $=1.3 \mathrm{e}-06$ square meters per day $(1.4 \mathrm{e}-05$ square feet per day), the Reynolds number is found to be about 3.0e-04. This is well below any value of concern and suggests that the linear form of Darcy's law is valid everywhere in the porous units of Frenchman Flat.

For flow in the fractured Lower Carbonate Aquifer, deMarsily (1986) suggests an alternative method to assess the onset of turbulent flow in fractured media and a corresponding deviation from a linear relationship similar to Darcy's law. A Reynolds number for flow in a planar fracture is given by:

$$
R e=\frac{v d_{h}}{\mu}
$$

Where:

$\mathrm{v}=$ average water velocity in the fracture $(\mathrm{m} / \mathrm{d})$

$\mathrm{d}_{\mathrm{h}}=$ hydraulic diameter $(\mathrm{m})$ [equal to 2 times the aperture for a long fracture]

$\mu=$ kinematic viscosity $\left(\mathrm{m}^{2} / \mathrm{d}\right)$

The velocity in the Lower Carbonate Aquifer is estimated to be $65 \mathrm{~m} / \mathrm{d}(213 \mathrm{ft} / \mathrm{d})$ along a pathline through the northwest corner of Frenchman Flat. This velocity was estimated using a Darcy velocity of $2.6 \mathrm{~m} / \mathrm{d}(8.5 \mathrm{ft} / \mathrm{d})$ and a mean effective porosity of 0.004 , both of which were taken from the regional evaluation report (DOE/NV, 1997). Using these values and the kinematic viscosity above yields a Reynolds number of about 23. For smooth fractures, deMarsily (1986) indicates that a linear relationship analogous to Darcy's law holds for Reynolds numbers less than 2,300. Therefore, in Frenchman Flat, there does not appear to be a need to consider second order terms in the momentum equation. Thus, the TRACR3D inclusion of a nonlinear Darcy term provides no advantage over other codes with only a linear Darcy term.

Another unique feature of TRACR3D is a number of solution options to more efficiently solve high Peclet number transport problems. This would be an advantage for simulation of steep fronts. This might occur near a source where dispersivity is smaller than in the far field. As the radionuclide front moves downgradient, the front will become more dispersed and the dispersivity will increase. This will reduce the Peclet number constraints.

Finally, TRACR3D lacks two potentially significant physical mechanisms. Neither temperature dependence nor matrix diffusion are included in the governing equations. Both of these exclusions make TRACR3D a less desirable choice.

SWIFT - The finite difference formulation of SWIFT has the same limitations as TRACR3D with regard to the representation of faults, physiographic, and structural boundaries. This is 
not expected to be a significant limitation for the Frenchman Flat CAU model. SWIFT does include all the physical mechanisms required for Frenchman Flat including advection, dispersion, adsorption, matrix diffusion, radioactive decay, daughter products, and temperature dependence. One difference between SWIFT and FEHM is the way in which the matrix is simulated. FEHM uses an infinite one-dimensional analytical approximation which simplifies numerical calculations, but limits the applications to situations where the diffusion of radionuclides does not reach the center of the matrix blocks. SWIFT approximates matrix diffusion via a one-dimensional diffusion equation oriented perpendicular to the fractures. The one-dimensional diffusion equation includes the matrix block size and is thus not limited in its application.

\section{Speed of Simulation}

FEHM - The Frenchman Flat example problem was simulated on a Pentium 366 PC. The setup of the test model was greatly facilitated with the help of staff at the LANL. The test model consisted of 49,000 nodes. As noted above, the example simulation required 330 megabytes of random access memory to run efficiently. The simulation time on the Pentium 366 was about 8 minutes. This simulation time is very fast and clearly adequate for the Frenchman Flat simulations.

TRACR3D - A test run of TRACR3D was not performed because it was determined via the ease of use and ability to simulate the appropriate physics criteria that FEHM and SWIFT were superior codes for the Frenchman Flat problem.

SWIFT - The test problem in SWIFT was implemented on a Pentium Pro 200 PC for the example problem. The area was discretized into 90 rows, 90 columns, and 14 layers for a total of 113,400 cells. The larger number of cells for the SWIFT simulation was selected in recognition of the inefficiency of a finite-difference grid with respect to a finite element mesh. The simulation time for this problem was about 33 minutes. This is slower than for FEHM, but well within the maximum simulation time criterion. The difference between FEHM and SWIFT is not as great as it appears because the Pentium Pro 200 is about a factor of two slower than the Pentium 366.

\section{Summary of the Code Evaluation}

Attributes - The attributes of the three codes were compared in Figure 5-3. Both FEHM and SWIFT address all the attributes deemed important for the Frenchman Flat simulations with the exception of colloid transport. The TRACR3D code is deficient with respect to temperature dependence and matrix diffusion. On the basis of the attributes, FEHM and SWIFT are preferred over TRACER3D. In the modeling approach document (IT, 1998), the finite-element formulation of FEHM was preferred over the finite-difference formulation of SWIFT. Therefore, FEHM is the first choice with respect to the code attributes.

Portability - The ability to pass the code to other interested parties and stakeholders is important. Most of the stakeholders, including the modeling group at IT and the DOE, will be 
using Pentium-based computers. The FEHM code is very sophisticated, but that is also a limitation with respect to portability. At the present time, and given the time constraints of the project, the FEHM code is less desirable from a portability standpoint. The other two codes, SWIFT and TRACR3D, being finite-difference, are more easily moved to various stakeholders, if necessary. For this criterion, SWIFT and TRACR3D tie for first.

Level of Quality Assurance Testing - All three codes have been extensively tested and documented. There does not appear to be a clear advantage to any of them.

Ease of Use - For a user unfamiliar with any of the three codes, the level of difficulty to attain mastery of the codes is probably about the same. For the Frenchman Flat CAU model, the time constraints of calibrating a model makes the ease-of-use criterion more of a familiarity criterion. The modeling team must rely on experts familiar with the codes to successfully complete the task on time. At this point in time, SWIFT experts are in house, and experts for the other codes exist only in agencies outside of the IT team. Given the limited time frame with which to complete the calibration, it is more efficient to use the SWIFT code, which is familiar to the modelers, rather than either of the other two codes.

Ability to Represent CAU Hydrogeology - The FEHM and SWIFT codes simulate all the processes of concern in Frenchman Flat, while TRACR3D fails to include temperature dependence or matrix diffusion. With respect to representation of physical features such as HSU contacts or faults, FEHM has an advantage. To effectively utilize SWIFT, vertical faults will be used instead of dipping ones. This is an approximation that is not necessary with FEHM. However, the dipping fault option with FEHM needs some additional development. This is likely to be completed in the near future, but not in time for the Frenchman Flat CAU modeling.

Simulation Speed - Only SWIFT and FEHM were tested for simulation speed. The FEHM code appears to run faster, 8 minutes versus about 15 minutes, when accounting for runs on different speed computers. As noted in the discussion, as long as the simulation time was less than about 6 hours, the speed was adequate. Therefore, it appears that either SWIFT or FEHM are adequate.

\subsubsection{Final Code Selection}

Based on the evaluation of the three codes selected for consideration, the determination is that SWIFT is the best code to use for the Frenchman Flat CAU modeling. Clearly, the finite-element formulation of FEHM offers some advantages. However, the complexity of FEHM also makes it difficult to implement for unfamiliar users within the limited time frame of the modeling task. The lack of potentially significant physical features in the TRACR3D program equations and some other features eliminated this code from further consideration. The approximations required to use SWIFT such as 
vertical faults are not expected to create significant inaccuracies in the results, especially when considering the paucity of drill hole data in Frenchman Flat.

\subsubsection{Model Construction}

The CAU model will be constructed in two steps. The groundwater flow model will be constructed first to define the flow field, followed by the contaminant transport model.

\subsubsection{Groundwater Flow Model}

This section describes the groundwater flow model construction process. The model construction process includes model setup and model calibration.

\subsection{Model Setup}

Several tasks must be completed to setup the groundwater flow model. These include: definition of the model grid, assignment of initial parameters, definition of CAU-model boundary fluxes, and determination of target heads for calibration.

\section{Model Grid}

The scale of the CAU models will be the approximate size of the CAU and the region downgradient in which the contaminant boundary is likely to occur. For the Frenchman Flat CAU, the area of the CAU model could extend from Massachusetts Mountain to the north, to the edge of the alluvium to the south, and from the Range Mountains in the east, to Mount Salyer to the west (Figure 1-2). Grid cell sizes will vary over the CAU model area. In the vicinity of the underground tests, the horizontal

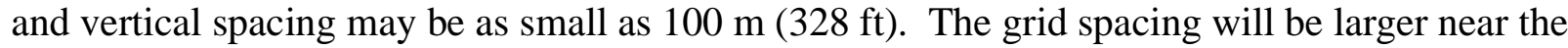
boundaries of the CAU model.

The SWIFT code is a finite-difference code; therefore, the approach for defining grids will be the same as the approach described in the regional flow model document (DOE/NV, 1997). The CAU model layers will be flat lying with layer boundaries chosen to coincide with key HSU boundaries in key locations. Faults will be assigned to individual grid cells to allow for an assessment of the effects of flow along faults. 
The precise features of the grid can be determined only when the modeling work begins.

Nonetheless, several criteria will be applied in defining the model grid. These criteria include:

- The external boundary of the CAU model will be rectangular and correspond to appropriate cell boundaries within the regional groundwater flow model. In this way, the total flux across a boundary from the regional groundwater flow model will be applied to the appropriate CAU-model boundary.

- Grid cells will be placed as close as practical at each underground test location as well as at specific well locations.

- Grid cells will be placed along faults that are identified as being important to the distribution of HSUs.

- The grid cell density will be greatest in the vicinity of the underground tests and at other points of interest such as discharge wells and will decrease in density at the CAU model boundaries.

- The total number of nodes is not yet defined, but the nodal spacing may be as small as $100 \mathrm{~m}$ (328 ft) in the vicinity of test cavities and wells to as large as the same size as the regional groundwater flow model grid at the CAU-model boundary.

\section{Boundary Conditions}

The boundary of the CAU-scale model will correspond to a predefined portion of the regional groundwater flow model. The actual CAU-model boundary will be determined during the initialization of the CAU modeling task. It is anticipated that the CAU-scale geologic model will differ from the regional geologic model at the CAU-model boundary. In addition, the regional groundwater flow model is defined on the basis of model layers that often do not correspond to geologic model layers. The external boundaries of the CAU-scale model will be specified-flux conditions as defined by the regional groundwater flow model. The corresponding regional flow model flux will be apportioned to model layers of the CAU-scale model on the basis of hydraulic conductivity.

In plan view, the external boundaries of the CAU model will coincide with selected rows and columns of the regional groundwater flow finite-difference model. The nodal spacing will be no greater than the regional groundwater flow model cell size. In the vertical direction, the layer boundaries of the CAU-scale model may not match the layer elevations of the regional flow model. 
As a result, a flux allocation approach may be employed whereby the total flux across a cell of the regional groundwater flow model is apportioned to the corresponding CAU nodes on the basis of water transmitting properties (hydraulic conductivity times cross sectional area). The external boundaries of the CAU model will be treated as constant flux, with the fluxes derived from the regional groundwater flow model.

It is anticipated that the CAU geologic model and the regional geologic model will differ at the boundary of the CAU model. This difference may lead to an artificial discontinuity that needs to be addressed during the modeling. To fix the discontinuity, the regional geologic model will need to be modified in some small region around the CAU model to remove inconsistencies between the two geologic models. The CAU geologic model will be inserted into the regional geologic model along with the corrections to the regional geologic model to remove the discontinuity. The regional groundwater flow system will be simulated with the updated regional geologic model. The additional simulation of the regional model is essential to providing accurate information at the CAU-scale. The CAU model depends on the regional groundwater flow model to provide the boundary fluxes necessary for flow and transport simulation. The additional detail in the CAU geologic model will, in all likelihood, alter the regional flow in the vicinity of the CAU. For the CAU-model boundary fluxes to be valid for CAU simulation, the fluxes must be consistent with the CAU geologic model. This will be accomplished by regional groundwater flow model simulations with the updated regional geologic model. This has the additional advantage that the regional groundwater flow model, thus modified, will be fully capable of simulating the impact of external water resource decisions on the CAU-boundary fluxes. Changes to the contaminant boundary location can then be determined with the CAU model and the modified boundary fluxes.

The bottom of the CAU model will be no deeper than in the regional groundwater flow model $(4,000 \mathrm{~m}[13,120 \mathrm{ft}]$ below sea level) and may be shallower. If the bottom is the same as the regional groundwater flow model, then the bottom of the CAU model will be treated as "no flow" as was the case in the regional model. Recent evaluations of the regional flow model have shown that little flow occurs deep in the model because of the small values of hydraulic conductivity. As noted in the regional model documentation (IT, 1996b) and Section 3.4 of this CAIP, the measured hydraulic conductivity data show a trend of decreasing values with depth. The deepest underground test on Frenchman Flat has a working point elevation of about $500 \mathrm{~m}(1,640 \mathrm{ft})$ amsl. The CAU model 
bottom may be significantly shallower than 4,000 $\mathrm{m}(13,120 \mathrm{ft})$ below sea level if it can be shown that very little flow occurs at the greater depths. If so, the regional groundwater flow model will be used to define fluxes through the bottom of the CAU model.

Finally, the recharge will be initially defined as in the regional groundwater flow model with the option of modifying it to account for increased spatial resolution on recharge provided by ongoing work by the DRI. Additional recharge in washes and along the basin margins will also be considered.

\section{Initial Flow Conditions}

Calibration of the CAU-scale groundwater flow model will be required to match simulated to measured hydraulic heads. The resulting simulated steady-state flow field will then become the initial condition for transient flow and transport simulations. The transient flow and transport simulations will include the effects of water well pumping and the timing of underground nuclear tests.

\subsection{Groundwater Flow Model Calibration}

Calibration of the CAU-scale groundwater flow model is the process for matching historical data and is usually a prerequisite for making predictions with a model. Calibration refines the modeled representation of the hydrogeologic framework, hydraulic properties, and boundary conditions to achieve a desired degree of correspondence between the model simulations and observations of the groundwater flow system. The CAU groundwater flow model will be calibrated using the manual method.

The flow simulations will be compared to site-specific information such as measured water levels and discharge fluxes. The calibration will produce quantitative and qualitative measures of the degree of correspondence between the simulation and site-specific information related to the physical hydrogeologic system. The degree of correspondence between the simulation and the physical hydrogeologic system can then be compared to that for previous simulations to ascertain the success of calibration efforts and, if needed, to identify potentially beneficial directions for further calibration efforts. Quantitative measures of correspondence will be developed based on the analysis of hydraulic head data. This will parallel the same effort that was undertaken for the regional flow model (DOE/NV, 1997). 
A two-step calibration process will be utilized for the CAU modeling. First, a preliminary calibration of the regional groundwater flow model will be performed after the enhancements to the regional geologic model are complete. This calibration is necessary to provide boundary conditions for the CAU model. The second step will be the calibration of the steady-state CAU-scale groundwater flow model. The amount of detail in the CAU model will allow for more refinement of the flow system and is expected to produce a better calibration to the CAU flow system. Within the CAU calibration, there may need to be several adjustments to the regional groundwater flow model as parameter values change in the CAU model. This will continue to ensure consistency between the regional and CAU groundwater flow models. During the calibration process, input parameters will in general be adjusted within their known ranges based on data, if sufficient data exist. In some cases, adjustments will be made within accepted estimated ranges if data do not exist or are scarce. In accordance with ASTM standard D-5981-96 (ASTM, 1996), the range of values for the calibration parameters will be presented in the data documentation packages. The model documentation will provide information on input parameters utilized in the model, and the genesis of these parameters.

Calibration targets will be established for both models. The regional groundwater flow model targets will be the same as in the final regional model report (DOE/NV, 1997) and will include both water levels and discharge fluxes. The CAU model will have water level calibration targets. The specification of the CAU-model boundary fluxes and the lack of internal natural discharge locations within the CAU eliminates discharge flux as a calibration target in Frenchman Flat.

The groundwater flow model for Frenchman Flat will be calibrated using ASTM standard guidance for calibrating groundwater flow models (ASTM, 1996). The Standard Guide for Calibrating a Ground-Water Flow Model Application is a guide for calibrating porous medium (continuum) groundwater flow models. The method can be adjusted to use on other types of groundwater models such as multiphase models, noncontinuum (karst or fracture flow) models, or mass transport models.

The ASTM standard procedures that will be used to implement the guidance cover the use of site-specific information (D5490), applying modeling to site-specific problems (D5447), defining boundary (D5609) and initial (D5610) conditions, performing sensitivity analyses (D5611), and documenting groundwater flow model applications (D5718) (ASTM, 1993a and b; 1994a, b, c; 1995). 


\subsubsection{Contaminant Transport Model}

The CAU contaminant transport model portion is constructed after the CAU flow model is calibrated. The contaminant transport model builds upon the flow model by simulating the movement of contaminants in the groundwater system simulated by the groundwater flow model. The groundwater flow model generates the hydraulic head field from which the specific discharge vectors are determined. The contaminant transport model accounts for a wide variety of processes including dispersion, advection, chemical interactions (sorption), radioactive decay, and matrix diffusion. Colloid transport processes are not included in the SWIFT code. If it is deemed necessary to simulate colloid transport, adjustments will need to be made in the approach. It is expected that contaminant transport will be primarily in the alluvium and the colloidal transport process will not be significant. This section includes a discussion of the data that are used to simulate transport and also gives an explanation of the model setup. The process of evaluating the sensitivity of the contaminant transport model to parameters is described, and the uncertainty analysis is defined.

\subsection{Model Setup}

The transport simulations build upon the flow paths generated by the CAU-scale steady-state groundwater flow model. The source term data will be derived from research being conducted by LLNL. The source for each test will be a flux of radionuclides per volume of water passing through the cavity, melt glass, and chimney. The initial runs will be performed using averaged data or declassified data from selected tests. Final runs will use classified source information for individual tests. Other parameter values such as dispersivity, matrix porosity, matrix diffusion, and effective porosity will be determined on a HSU basis. Initially, mean parameter values will be determined for each HSU. Later, during the uncertainty analyses, the variability in parameter values will be included in the calculations.

\subsection{Transport Model Calibration}

Radionuclide data from groundwater in Frenchman Flat will be evaluated as additional calibration targets. The only known radionuclide migration data for Frenchman Flat is associated with the CAMBRIC RNM Experiment (Bryant, 1992a). In that experiment, a well was placed about $91 \mathrm{~m}$ $(300 \mathrm{ft})$ away from the CAMBRIC working point and pumped for about 17 years. The radionuclide breakthrough data are available, but cannot be readily simulated with the Frenchman Flat model. The 
grid spacing of the CAU model is designed for larger scale simulations and is on the order of $100 \mathrm{~m}$ $(328 \mathrm{ft})$, the size of the CAMBRIC experiment. It is not possible to accurately simulate the details of the CAMBRIC experiment with a grid size of $100 \mathrm{~m}(328 \mathrm{ft})$. Other radionuclide data are not available for Frenchman Flat.

\subsubsection{Sensitivity Analyses}

The purpose of the sensitivity analyses will be to determine the change in the CAU model predictions due to changes in parameter values. A systematic process will be implemented whereby a parameter is increased and then decreased a constant factor from the calibrated value and additional simulations performed to identify the change in calibration residuals.

Sensitivity analyses are similar to the uncertainty analyses of parameter values except that each parameter is varied a fixed amount rather than over its range of uncertainty. To perform the sensitivity analysis, each parameter will be increased, then decreased by a fixed amount (e.g., a factor of two). The resulting change in the predicted contaminant concentrations will be compared for each parameter. This provides an assessment of the most sensitive parameters.

Identifying the more sensitive parameters is important for two reasons. The more sensitive a parameter is for calibration of the groundwater flow model, the narrower the range of acceptable values that will result in acceptable calibration. Therefore, one may conclude that the most sensitive calibration parameters are defined within the narrowest range of uncertainty.

For the transport calculations, where predictions extend well into the future, the sensitivity provides different information. The most sensitive parameters for contaminant transport do not have reduced uncertainty because it is not possible to calibrate to future events. The most sensitive transport parameters identify the parameters of most concern because the range of uncertainty must be constrained by information external to the contaminant transport model.

\subsubsection{Uncertainty Analyses}

Uncertainty in this context refers to the uncertainty in the contaminant concentration in the CAU, which in turn leads to uncertainty in the location of the contaminant boundary. The location of the contaminant boundary is determined via modeling; therefore, any uncertainty in the geologic model, 
source term, parameter values, or boundary conditions is a potential source of contaminant boundary uncertainty. In addition, the definition of the contaminant boundary itself, if subject to change, is also a source of uncertainty.

Alternative geologic models reflect differences in professional judgment regarding the geology of the CAU. Oftentimes the data are insufficient to differentiate between competing geologic interpretations. The importance of the competing interpretations can be evaluated by modifying the flow and transport input files to reflect the alternatives and to simulate the resulting changes in water levels and contaminant migration. For this analysis, a limited number of alternatives (less than ten) will be identified. Each alternative may require more than one simulation to evaluate. One example of this analysis is the assessment of the influence of fault zones. Faults may be barriers to flow, conduits of flow, or some function in between. In the CAU model, fault zones can be identified individually and accounted for, independent of the surrounding rocks. Several simulations with faults as barriers or conduits will assess the uncertainty due to fault properties.

Another example of an alternative interpretation would be the absence or presence of an aquifer unit. After identifying the location of the disputed geologic unit, the material properties (hydraulic conductivity or effective porosity) can be configured to represent an aquifer or a confining unit. A simulation will be run with the unit configured in each way, and the resulting impact on the water levels and contaminant transport will be observed. In this way the impact to contaminant predictions of adding or removing an aquifer unit from the geologic interpretation can be assessed.

Source-term uncertainty may come from uncertainty in the release scenario of the source or the concentration. The source-term release scenario describes the mode of radionuclide release. For example, some radionuclides such as tritium are assumed to be nearly 100 percent released to the groundwater shortly after the test cavity resaturates. Other radionuclides are incorporated into melt glass or chimney rubble and are released at a slow rate over time. The range of possible release scenarios will be included in a set of three or four simulations in which the mode of release is varied among several possibilities that will be identified by LLNL.

The other source-term uncertainty is the initial concentration or release rate uncertainty. The initial concentration or the rate of release may be uncertain. The source term experts at LLNL and LANL 
will be consulted to provide ranges of input concentrations and release mechanisms that are appropriate for sensitivity analyses. These ranges will be quantified through the establishment of probability density functions (pdf) describing the variability of each parameter. These pdfs will be used as input to Monte Carlo analyses to assess the impact on predicted contaminant concentrations. The Monte Carlo analyses are described below.

Parameter value uncertainty comes from several sources and varies with the scale of the measurement. One source of uncertainty is limited data with which to estimate large-scale parameter values. A second source of uncertainty is a parameter that varies spatially in a geologic unit. Uncertainty due to limited data is considered reducible because additional data collection will provide better estimates of the mean value. Spatial variability is an irreducible uncertainty because limited data collection does not provide sufficient information to define the spatially variable parameter in much detail.

Large-scale parameters that are uncertain include hydraulic conductivity, recharge, effective porosity, matrix diffusion terms, and mean groundwater flux. The uncertainty in each of these parameters will be described by a pdf and will be included in the Monte Carlo analyses along with the source-term parameters. These large-scale parameters represent averages of smaller scale processes, such as spatial variability. As such, the uncertainty in the average value is a function of the small-scale variability and the number of data points. In general, the range of variability in the large-scale average parameter is much smaller than the small-scale parameter. As such, pdfs of the large-scale parameters will reflect reduced ranges of variability.

One additional source of uncertainty to be considered is the unmeasured spatial variability of the key aquifer parameters. Hydraulic conductivity, for example, is known to vary both laterally and vertically, even within the same aquifer unit. At a small scale (up to several kilometers), these unmeasured spatial variations may strongly influence the direction, velocity, and dispersion of transported contaminants. Researchers at the DRI (Pohlmann and Andricevic, 1994; Shirley et al., 1996; Pohlmann et al., 1996) have developed a stochastic method to describe this spatial variability using a three-dimensional random field generator described in Section 5.2.2. To assess the impact of the spatial variability, 30 to 50 realizations of the random field will be generated. Each realization represents a possible picture of reality. The effect of each random field on the migration of 
contaminants in the groundwater system will be simulated with the CAU model. Each random field will be input to the groundwater flow model and a set of hydraulic heads will be simulated.

Contaminant transport will then be simulated for each realization. This will provide an assessment of the uncertainty in the flow path and an understanding of the importance of the spatial variability.

Monte Carlo simulations generally require that parameter values be sampled from a probability distribution and simulated for many trials (realizations) of the parameter value. This process can be time-consuming because it involves repeated simulations of the CAU model. For a large three-dimensional groundwater flow and contaminant transport model, it may become intractable to perform the many simulations that are often required. To address this problem, a two-tiered Monte Carlo approach is proposed. First, one-dimensional pathlines will be generated from the three-dimensional groundwater flow model. Along these pathlines, one-dimensional contaminant transport modeling will be performed in a manner analogous to the regional transport model. This is an efficient method to assess the parameter uncertainty for source term, effective porosity, and matrix diffusion. Afterward, a reduced set of parameters will be selected for additional three-dimensional Monte Carlo simulations. The reduced set will be the most sensitive of the parameters from the one-dimensional simulations.

Boundary condition uncertainty must also be considered. Two boundary conditions will be considered in the uncertainty analysis. One is the recharge component, which will vary spatially and the second boundary uncertainty is the flux defined by the regional groundwater flow model. The magnitude and location of the flux is a function of the parameters used in the regional groundwater flow model. As a result, regional model uncertainty will produce an uncertainty in the CAU model. Each boundary uncertainty will be investigated by perturbing the values within defined ranges and observing the impact of the simulated contaminant concentration.

Many sources of uncertainty have been identified in the previous discussion. The approach to quantify the uncertainty in parameter values is via a probability distribution and the use of a Monte Carlo approach to generate parameter realizations that are used in the CAU model. The probability distribution of model response (contaminant concentrations) is determined from the simulations and provides an assessment of uncertainty in the model predictions. The advantages of the Monte Carlo approach are that it is relatively straightforward to implement, can account for correlated parameters, 
can incorporate spatially correlated random variables, and takes full advantage of the computational rigor of the CAU model. One disadvantage of the Monte Carlo approach is the computational burden of multiple simulations. This disadvantage can be reduced by selective sampling (i.e., via a Latin Hypercube Sampling technique) to reduce the number of realizations. The Monte Carlo method can provide a quantitative measure of the uncertainty in the location of the contaminant boundary as a function of the number of realizations that produced less distant contaminant boundary locations.

Assessment of sources of uncertainty that cannot be described via a probability distribution will be included in a different manner. The alternative interpretations of the geologic model, for example, will be described by a limited number of interpretations, not by a probability distribution. The amount of change in the contaminant boundary location from an alternative geologic model will be compared with the Monte Carlo results to identify the comparable change due to parameter uncertainty. For example, if an alternative geologic model resulted in a 500-m (1,640-ft) change in the contaminant boundary, how would that compare with the change in the contaminant boundary location from the 50 percent to 75 percent level in the Monte Carlo analysis? If $500 \mathrm{~m}(1,640 \mathrm{ft})$ corresponded to 55 percent, then it would appear the uncertainty in the contaminant boundary location due to that alternative geologic interpretation is small. If $500 \mathrm{~m}(1,640 \mathrm{ft})$ percentage was 90 percent, then the alternative geologic interpretation would be considered more important. Other sources of uncertainty that cannot be described by a probability function will be treated in a similar manner. These would include the heterogeneity of hydraulic conductivity and variation of the CAU-model boundary fluxes.

\subsubsection{Model Review}

A thorough review of the CAU model will be performed to assess its adequacy. The purpose of this assessment is to verify the modeling approach process and to determine if the modeling process can move forward to the verification phase. The review will be based on the first draft model documentation discussed in Section 5.1.11. The CAU model will be reviewed by four groups:

- An internal peer review group consisting of the DOE TWG Modeling Subcommittee

- An external peer review group consisting of prominent members of the groundwater modeling community 
- The DOE management

\section{- The NDEP}

The internal and external peer groups will be asked to attempt to identify fatal flaws in the CAU model and to evaluate whether the modeling process has been applied correctly. In addition, the peer reviewers will be asked to assess the ranges of parameter uncertainty incorporated into the CAU model and to verify that the range of parameter uncertainty is inclusive. In conjunction with the results of the peer review, DOE management and NDEP will determine if the modeling process can move into the model verification phase by not rejecting the CAU model as presented. If either DOE or NDEP reject the CAU model, DOE and NDEP will enter into discussions to determine how to proceed. If neither DOE nor NDEP reject the CAU model, the model verification phase will begin.

\subsubsection{Model Verification}

Model verification is defined as the testing of predictions of the calibrated model against available data not used in the model production and calibration.

For the Frenchman Flat steady-state groundwater flow model, it is expected that all the available steady-state data will be used. Transient hydraulic head response data from water supply well pumping will be used to verify the groundwater flow model calibration prior to the sensitivity and uncertainty analyses and the model review. This verification consists of a transient flow calibration which includes adjusting the storage coefficient to match simulated to observed drawdown in wells. The effectiveness of this model verification will depend on the accuracy of the groundwater discharge data.

It may also be necessary for additional data to be collected for purposes of model verification. However, until the CAU modeling is complete, it is not possible to state what type of data should be collected and whether new wells will need to be installed. The new data collection types and locations will be determined from the CAU model's response to the uncertainty and sensitivity analyses. After completion of the CAU model, a verification plan will be prepared and submitted to the NDEP for approval. This plan will identify what data are to be collected, where they will be collected, and the acceptable range of data uncertainty. Data representing both model inputs and outputs will be collected. These new data may include water levels, model parameters, geochemistry 
parameters, and contaminant concentrations. These data will be compared against the results of the CAU model predictions consistent with the time period in which the verification data are collected. The data collected for model verification will be designed to provide positive comparison to model inputs and outputs and will be compared with the range of values corresponding to the 5 percent and 95 percent bounds of the specific parameter.

One of several approaches may be used to determine if the new data verify the CAU model predictions. In the case of data for which the number of values are sufficient to determine a pdf, the new data will be shown to be consistent with the previously defined pdf by comparing mean and standard deviation values before and after inclusion of the new data. If the new data do not significantly change the mean and standard deviation, that parameter will be considered verified. In other cases, for which upper and lower bounds have been defined, the new data will be compared with the bounds. The new data will be considered to be verified if the results fall within the 5 percent and 95 percent ranges defined for that data.

If the data significantly modify the pdf or if they fall outside of the 5 percent and 95 percent ranges, the CAU model will not have been verified. In this case, DOE and NDEP will initiate discussions to identify the appropriate path forward.

\subsubsection{Model Predictions}

The stated purpose of the CAU model is to provide predictive simulations of radionuclide migration away from underground test cavities for a period of 1,000 years. For each contaminant, the CAU model will predict the concentration at each node in the model at each time step from 0 to 1,000 years. These data will be processed to calculate a contaminant boundary location. The contaminant boundary is defined as the maximum extent of the $4 \mathrm{mrem} / \mathrm{yr}$ composite dose which is made up of the sum of the doses from each of the contaminants. The results will be presented as a median location of the contaminant boundary along with 5 percent and 95 percent locations of the contaminant boundary based upon the uncertainty analyses.

Uncertainty in the contaminant boundary location will be evaluated using the Monte Carlo simulation results for parameters and spatial variability and will be combined with the uncertainty from the CAU model simulations using the alternative geologic model. In all cases, the contaminant boundary 
location will be calculated from the contaminant concentration data generated by the contaminant transport model.

\subsubsection{Model Documentation}

The CAU model and results will be presented in the same level of detail as in the previous regional model documentation package (IT, 1997a). The regional model documentation package included descriptions of the numerical model, the model grid, model_boundary conditions, aquifer parameter assignments, model calibration, sensitivity analyses and presentation of results. For the CAU model, the same information will be presented for the groundwater flow model. Additional information will be added for the transport simulations. This additional information will include the transport parameters, source term, and results which will be presented in terms of the location of the $4 \mathrm{mrem} / \mathrm{yr}$ composite dose contaminant boundary. The results will be presented as a median location of the contaminant boundary along with 5 percent and 95 percent locations of the contaminant boundary based upon the uncertainty analyses.

Additional results showing contaminant concentrations and the location of the contaminant boundary at selected times will also be presented. These times may include the verification period, the end of the 5-year proof-of-concept period, as well as other times that are of specific interest.

\subsubsection{Postaudit}

The final component of the validation process is the design of postaudit data collection to provide longer term verification of the CAU model predictions. The postaudit data collection will be integrated as part of the CAP. The details of the postaudit will not be available until the CAP is written. Nonetheless, the general approach to the postaudit will be aimed at continued verification that the CAU model output uncertainty is inclusive of actual future conditions.

The predicted contaminant boundary will be the median of the uncertainty analysis. As such, the contaminant boundary does not represent a specific prediction, but instead is an expected value derived from multiple simulations of flow and transport processes. The DOE acknowledges that the contaminant boundary is an uncertain quantity and will provide quantified bounds on the uncertainty in the contaminant boundary location. The postaudit is designed to be the final stage of a thorough 
process of model verification designed to demonstrate that the contaminant boundary location has been bounded with reasonable assurance.

\subsection{Other Models Supporting the Frenchman Flat CAU Model}

In the preceding discussion, several models were identified as providing supporting information for the Frenchman Flat CAU model. These additional models include the regional groundwater flow model (DOE/NV, 1997), a random field generator developed by the DRI, and a near-field model developed by LLNL. The regional groundwater flow model provides the CAU-model boundary fluxes necessary to ensure that the CAU model is consistent with the regional groundwater flow system. The DRI random field generator creates realizations of spatially variable parameters that will aid in assessing uncertainty in the simulated contaminant boundary. The near-field hydrologic source-term model provides the spatial distribution, release rates, and near-source mobility of a variety of radionuclides. This discussion of other models supporting the Frenchman Flat CAU model is adapted from a the UGTA modeling approach document (IT, 1998).

\subsubsection{Regional Groundwater Flow Model}

The regional groundwater flow model (DOE/NV, 1997) provides the necessary regional framework for the CAU-scale model. The regional model balances groundwater inflows and outflows on a regional scale to ensure that a large scale model flow is consistent with measured water levels, inflows, and outflows. For the CAU model results to be considered valid, the groundwater flow through the CAU model must be in balance with the regional model predictions.

The refinements to the $\mathrm{CAU}$ geologic model may perturb the regional flow with respect to the current regional model. In addition, the CAU geologic model defines HSUs that are unknown in the regional model. Flow parameter values for the new HSUs must be assigned in conjunction with the overall regional flow system. This requires adding CAU-scale geology to the regional geologic model and modifying the regional geologic model at the border of the CAU model to remove any inconsistencies at the CAU-model boundary. The regional groundwater flow model will then be recalibrated and used to provide the necessary boundary conditions for the CAU-scale model (IT, 1998a). 


\subsubsection{Random Field Generator}

Modeling of contaminant migration in heterogeneous geologic formations requires detailed descriptions of the subsurface. A heterogeneous formation has spatially-variable composition, structure, physical properties, and chemical characteristics. Hydrogeologic heterogeneities of natural formations cannot be measured in sufficient detail to provide data at all locations within a given study area. Alternatively, the properties of heterogeneous formations may be described using a stochastic approach. Using this method, a set of equiprobable subsurface representations of a given formation property is generated via a Monte Carlo-type technique (Journel, 1989 and Deutsch and Journel, 1992). Each of the representations, or realizations, is one possible model of the true subsurface spatial variability. A statistical evaluation of the possible outcomes is performed by generating many of these realizations. By examining the flow field through each of these realizations, it is possible to derive estimated values of effective parameters, such as dispersivity, at scales appropriate for the CAU model.

Researchers at the Desert Research Institute have developed such a stochastic methodology to create maps of a specified property (for example, hydraulic conductivity) using borehole, core, and geophysical log data. The DRI researchers use a three-dimensional random field generator to create equiprobable alternative random fields that honor measured data and offer a series of possible values in areas where no measured data are available. These possible values (called realizations) describe the uncertainty in the spatial variation of the hydraulic conductivity. The method has been applied to the Frenchman Flat CAU and has been documented in two reports by Pohlmann and Andricevic (1994) and Shirley et al. (1996). The randomly-generated fields of formation properties will be used in the uncertainty analyses to be performed using the CAU-scale model as described in Section 5.1.7.

The variability of hydraulic conductivity will be described at a small scale as part of the random field generation process. Typically, this will involve the generation of spatial realizations with a grid density greater than the CAU model grid. The random fields will, thus, include finer detail than the CAU model itself and a larger degree of variability. These random fields may be used in the CAU model following one of several approaches. The smaller-scale random fields could be averaged into the CAU-model scale and simulated. This approach will capture the larger-scale trends in the random fields, but some of the detail will be lost in the process. Nonetheless, this may still be adequate to capture the effect of spatial variability. An alternative approach would be to simulate with the 
detailed random field as provided, but to limit the model area to a portion of the CAU model in the vicinity of the sources. This approach preserves the variability in the random fields. In either case, the averaging that is present in natural flow systems will be part of the result. In one case, the averaging is external to the model, at least at scales smaller than the CAU model grid, and in the other case the averaging is performed by a sub-model at a scale less than that of the CAU model. Either approach should be acceptable.

\subsubsection{Near-Field Model}

The release of radionuclides from source terms associated with underground nuclear tests to groundwater is a complex process. The various potential contaminants are distributed unevenly into the cavity fluids, the melt glass, the chimney rubble, and the region surrounding the cavity. The rate at which these contaminants are released to the groundwater is a complex interaction of contaminant, rock, and water interactions. A LLNL team of scientists is conducting a set of geochemical and hydrologic modeling activities to evaluate the nature of the radioactive hydrologic source term at a typical saturated zone nuclear test in Frenchman Flat, with emphasis on the migration of actinides.

These near-field simulations will provide information about the hydrologic source term, including the abundance of radionuclides present, their distribution, and the rate and extent of their migration in the vicinity of the nuclear test cavity. The results of the near-field simulations will be used to describe the hydrologic source term in the CAU-scale model. It is expected that much of the detail in the near-field model can be summarized into a smaller number of simpler models to describe CAU-scale processes of importance. At the time of preparation of this CAIP, the LLNL work is in progress.

The source term modeling accounts for the spatial distribution of radionuclides in the cavity and melt glass, the chemical interaction of the radionuclide species with the rock and cavity material, and the release mechanisms from the cavity. The source term model simulates reactive radionuclide migration along a large number of one-dimensional pathlines that pass from the alluvial aquifer, through the cavity and melt glass, and back into the aquifer. The integrated flux of radionuclides, in moles per time, leaving the cavity and melt glass region and passing through a plane approximately two cavity radii away is determined for each radionuclide. That mass flux of radionuclide is the amount of mass included as a source term in the CAU transport model. To the extent that available data allows, the source term model predictions will be compared with observations. 


\subsection{Field Investigation/No Field Investigation}

This section includes the rationale for not conducting a field investigation of the Frenchman Flat CAU prior to the modeling task. The process to be followed for proposing additional characterization activities, if necessary, is also outlined.

\subsection{No Field Investigation}

As explained in Section 4.0, no additional characterization information will be collected prior to the development of the CAU-scale model. This recommendation was made to the UGTA Project Manager by the Technical Working Group, following completion of the VOIA (IT, 1997c). The existing data were deemed sufficient to develop a CAU-scale groundwater flow and contaminant transport model, use it to evaluate the impacts of various sources of uncertainty, and subsequently decide whether additional data were needed or not.

Using the results of the Frenchman Flat VOIA (IT, 1997c), the Technical Working Group concluded that the available data are sufficient to develop a groundwater flow and contaminant transport model to simulate contaminant migration within the Alluvial Aquifer and to evaluate the potential for contaminant migration to the Lower Carbonate Aquifer via vertical movement. As concluded in the VOIA, additional characterization of the Alluvial Aquifer is not cost-effective because the improvement in the uncertainty of the simulated contaminant boundary location is insignificant when compared to the large investment costs. Even though information on the Lower Carbonate Aquifer is scarce in Frenchman Flat and was found to be insufficient to evaluate the potential for vertical contamination movement, it was decided that sufficient data were available to set up the CAU model, incorporating the current understanding of the Lower Carbonate Aquifer and its relationship to the overlying aquifers, and evaluate the possibility of vertical contaminant movement.

The CAU model will be used to assess the impacts of various sources of uncertainty using sensitivity and uncertainty analyses. For example, the CAU model will be used to evaluate various plausible interpretations of the geology and groundwater hydrology of Frenchman Flat where uncertainties exist and to evaluate the corresponding impact on contaminant migration, including the possibility of vertical contaminant migration. 
Based on the modeling results, the DOE and NDEP will decide if the level of uncertainty associated with the CAU model predictions of the location of the contaminant boundary is acceptable. If either DOE or NDEP find the level of uncertainty unacceptable, additional characterization activities will be considered.

\subsection{Additional Characterization Activities}

The potential for additional characterization activities is a possible option identified in the UGTA strategy as discussed in Section 2.0. Additional characterization may be considered if the CAU model is not acceptable to DOE or NDEP.

As shown in Figure 1-2, DOE will evaluate the CAU model results and associated uncertainties before submittal to the NDEP. If the CAU model is unacceptable to DOE, further characterization may be considered. For example, if the CAU model results show that significant vertical movement of contamination into the Lower Carbonate Aquifer could exist and affect the location of the simulated contaminant boundary, DOE may consider additional characterization activities to resolve the uncertainties associated with vertical contaminant migration.

If after completion of the CAU-scale model to DOE's satisfaction, DOE and NDEP cannot agree upon the CAU model or the contaminant boundary, then DOE and NDEP will determine if the strategy, as defined in the FFACO, can still be achieved. If both parties agree that the strategy can still be achieved, DOE and NDEP will determine the appropriate path forward.

If additional data collection is necessary, the types and/or locations of new data would be determined using the results of the CAU-scale model, particularly the sensitivity and uncertainty analysis results. Following collection and analysis of any new data, the CAU-scale model would be recalibrated, if necessary, and used to simulate the location of the contaminant boundary. Plans for any additional data collection, data analysis activities, and CAU model update would be documented in a separate plan as an addendum to the CAIP. 


\subsection{Quality Assurance}

A comprehensive quality assurance program has been developed for all activities performed under the UGTA Subproject, including those defined in this CAIP. That program is documented in the Underground Test Area Quality Assurance Project Plan (QAPP), Revision 2, dated February 1998 (DOE/NV, 1998). This CAI requires two of the different types of activities addressed in the QAPP: assessment of existing data and modeling. Each are discussed below.

\subsection{Assessment of Existing Data}

Section 5.1 of the UGTA QAPP addresses evaluation of data, including existing data. During the data documentation evaluation for this CAI, in addition to the requirements in the QAPP, flags will be assigned to indicate the level of knowledge about the data collection process and traceability. The five levels of Data Documentation Evaluation Flags are as follows:

Level 1: Data are collected in accordance with DOE/NV ERP subproject quality assurance plans, approved State of Nevada procedures, and/or participant-specific procedures. This ranking indicates that all supporting documentation for the data is on file and is available for review by data users.

Level 2: Data are collected in accordance with approved plans and procedures as required for Level 1 with the exception that one or more documentation requirements may be deficient in some way. Examples of data documentation deficiencies may include lost or destroyed field-data collection forms or data acquired using interim or draft procedures.

Level 3: Data are collected using accepted scientific methodology (e.g., ASTM or EPA methods, USGS procedures) and accompanied by supporting and corroborative documentation such as testing apparatus diagrams, field or laboratory notes, and procedures. Documents referenced to qualify submitted data under the Level 3 category shall be noted and described in Part II of the Data Information Form.

Level 4: Data are collected by a participating DOE/NV ERP organization or another organization not associated with the DOE/NV ERP prior to the issuance and implementation of project-approved standard policies, procedures, or practices governing data acquisition and qualification. The methods of data collection are documented and traceable; however, the validity and prudency of data use or compliance with referenced procedures is indeterminate. Supporting documentation may or may not exist. Documentation provided to qualify submitted data under Level 4 shall be noted and described in Part II of the Data Information Form. 
Level 5: Data are obtained under unknown, undesirable, or uncertain conditions. When data documentation is unknown, any available supporting or helpful descriptions of the intended use and conditions of data capture should be described and listed in Part II of the Data Information Form.

Based on the traceability of the data, individual records will be further evaluated for suitability of use for the purposes of this CAI.

\subsection{Modeling}

The quality assurance requirements for modeling are specified in Section 5.2 of the UGTA QAPP (DOE/NV, 1998) and generally consist of software/hardware configuration control, technical evaluation of new codes, code verification and validation activities, and software documentation. Output from modeling runs will be well-documented and traceable to the code from which it was generated. Participating organizations' procedures will provide details for the specific methods used for performing these activities. 


\subsection{Duration and Records/Data Availability}

A tentative schedule for completion of major activities associated with the CAI is provided in Table 8-1.

\subsection{Document/Records Availability}

This Corrective Action Investigation Plan and all unclassified primary supporting documents/ documentation are available to the extent allowed by law (and as addressed in paragraph XIII.3 of the FFACO), in the DOE Public Reading Rooms located in Las Vegas and Carson City, Nevada, and from the DOE UGTA Project Manager. The Nevada Division of Environmental Protection maintains the official administrative record for all activities conducted under the auspices of the Federal Facility Agreement and Consent Order (FFACO, 1996). For further information about where to obtain documents and other data relevant to this plan, contact Mr. Robert Bangerter, Project Manager, UGTA Project, at (702) 295-7340.

Table 8-1

Schedule of Activities

\begin{tabular}{|l|c|}
\hline \multicolumn{1}{|c|}{ Investigation Activity } & \multicolumn{1}{c|}{$\begin{array}{c}\text { Completion Time } \\
\text { (in months after initiation of CAI) }\end{array}$} \\
\hline \hline Complete Data Analysis & 9 months \\
\hline Complete Contaminant Boundary Modeling & 26 months \\
\hline Complete Monitoring Network Design & 28 months \\
\hline Complete CADD & 38 months \\
\hline
\end{tabular}




\subsection{References}

Adams, S.R., IT Corporation 1996a. Memo to B.J. Deshler regarding UGTA feasibility and Frenchman Flat Value of Information Studies Support Calculations, October 8. Las Vegas, NV.

Adams, S.R., IT Corporation. 1996b. Memo to J.N. Wille regarding UGTA subcommittee on source terms: dose evaluation for individuals ingesting radiologically contaminated groundwater, 17 June. Las Vegas, NV.

American Society for Testing Materials. 1993a. Standard Guide for Application of a Ground Water Flow Model to Site-Specific Problem, ASTM D 5447-93. Philadelphia, PA.

American Society for Testing Materials. 1993b. Standard Guide for Comparing Ground-Water Flow Model Simulations to Site-Specific Information, ASTM D 5490-93. Philadelphia, PA.

American Society for Testing Materials. 1994a. Standard Guide for Defining Boundary Conditions in Ground-Water Flow Modeling, ASTM D 5609-94. Philadelphia, PA.

American Society for Testing Materials. 1994b. Standard Guide for Defining Initial Conditions in Ground-Water Flow Modeling, ASTM D 5610-94. Philadelphia, PA.

American Society for Testing Materials. 1994c. Standard Guide for Conducting a Sensitivity Analysis for a Ground-Water Flow Model Application, ASTM D 5611-94. Philadelphia, PA.

American Society for Testing Materials. 1995. Standard Guide for Documenting a Ground-Water Flow Model Application, ASTM D 5718-95. Philadelphia, PA.

American Society for Testing Materials. 1996. Standard Guide for Calibrating a Ground-Water Flow Model Application, ASTM D 5981-96. West Conshohocken, PA.

Ames, L.L., and D. Rai. 1978. Radionuclide Interactions with Rock and Soil Media, Volume 1: Processes Influencing Radionuclide Mobility and Retention, Element Chemistry and Geochemistry, Conclusions and Evaluation, EPA 520/6-78-007-A. Las Vegas, NV: U.S. Environmental Protection Agency.

Armstrong, R.L. 1968. "Sevier Orogenic Belt in Nevada and Utah." In Geological Society of America Bulletin, Vol. 79 (4): 429-458. Boulder, CO.

Arteaga, F.E., C.S. Savard, M.E. Johnson, and J.C. Stone. 1991. Hydrogeologic Data from Selected Wells and Test Holes in and Adjacent to the Nevada Test Site, Nye County, Nevada, through 1986, USGS-OFR-87-536. Denver, CO: U.S. Geological Survey. 
Ashby, S.F., C.H. Baldwin, W.J. Bosl, R.D. Falgout, S.G. Smith, and A.F.B. Thompson. 1996. Application and Implementation of the Parflow Groundwater Flow Model, UCRL-JC-125919. Los Alamos, NM: Los Alamos National Laboratory.

ASTM, see American Society for Testing Materials.

Barnes, H., E.B. Ekren, C.L. Rodgers, and D.C. Hedlund. 1982. "Geologic and Tectonic Maps of the Mercury Quadrangle, Nye and Clark Counties, Nevada,” Map I-1197, Scale 1:24,000.

Denver, CO: U.S. Geological Survey.

Barone, F.S., R.K. Rowe, and R.M. Quigley. 1992. "Estimation of Chloride Diffusion Coefficient and Tortuosity Factor for Mudstone." In ASCE Journal of Geotechnical Engineering, Vol. 118 (7): 1031-1045. New York, NY.

Bear, J. 1972. Dynamics of Fluids in Porous Media. New York, NY: American Elsevier.

Bear J. 1979. Hydraulics of Groundwater. New York, NY: McGraw-Hill.

Bechtel Nevada. 1997. Nevada Test Site Annual Site Environmental Report for Calendar Year 1996, DOE/NV/11718-137. Las Vegas, NV.

Bechtel Nevada. 1999. Nevada Test Site 1998 Data Report: Meteorology, Water Balance, and Neutron Logging Monitoring Programs - Area 3 and Area 5 Radioactive Waste Management Sites. Las Vegas, NV.

Blout, D.O., D.P. Hammermeister, K.A. Zukosky, and K.D. Donnelson. 1994. Site Characterization Data from the Area 5 Science Boreholes, Nevada Test Site, Nye County, Nevada. Las Vegas, NV: Reynolds Electrical \& Engineering Company, Inc.

BN, see Bechtel Nevada.

Borg, I.Y., R. Stone, H.B. Levy, and L.D. Rampspott. 1976. Information Pertinent to the Migration of Radionuclides in Ground Water at the Nevada Test Site, Part I: Review and Analysis of Existing Information, Report UCRL-52078. Livermore, CA: Lawrence Livermore National Laboratory.

Bryant, E.A. 1992a. The Cambric Migration Experiment: A Summary Report, LA-12335-MS. Los Alamos, NM: Los Alamos National Laboratory.

Bryant, E.A. 1992b. Colloid Research for the Nevada Test Site, LA-12301-MS. Los Alamos, NM: Los Alamos National Laboratory.

Bryant, E.A., and J. Fabryka-Martin. 1991. Survey of Hazardous Materials Used in Nuclear Testing, Report LA-12014-MS. Los Alamos, NM: Los Alamos National Laboratory. 
Buddemeier, R.W. 1988. Hydrology and Radionuclide Migration Program 1985-1986 Progress Report, UCRL-53779. Livermore, CA: Lawrence Livermore National Laboratory.

Buddemeier, R.W., and J.R. Hunt. 1988. "Transport of Colloidal Contaminants in Groundwater: Radionuclide Migration at the Nevada Test Site." In Applied Geochemistry, Vol. 3: 535-548. London, England: Pergamon Press.

Buddemeier, R.W., R.C. Finkel, K.V. Marsh, M.R. Ruggieri, J.H. Rego, and R.J. Silva. 1989. Hydrology and Radionuclide Migration at the Nevada Test Site," UCRL-102033. Livermore, CA: Lawrence Livermore National Laboratory.

Bunch, R.L., and J.R. Harrill. 1984. Compilation of Selected Hydrologic Data from the MX Missile-Siting Investigation, East-Central Nevada and Western Utah, USGS-OFR-84-702. Denver, CO: U.S. Geological Survey.

Burbey, T.J., and S.W. Wheatcraft. 1986. Tritium and Chlorine-36 Migration from a Nuclear Explosion Cavity, DOE/NV/10384-09, Publication No. 45050. Las Vegas, NV: Desert Research Institute.

Byers, F.M., Jr., and C.H. Miller. 1966. Geologic and Geophysical and Geophysical Log of the Ue5k Exploratory Hole, Frenchman Flat, Nevada Test Site, USGS NTS-164, Technical Letter. Denver, CO: U.S. Geophysical Survey.

Carr, W.J., G.D. Bath, D.L. Healey, and R.M. Hazelwood. 1975. Geology of Northern Frenchman Flat, Nevada Test Site, USGS-OFR-474-216. Denver, CO: U.S. Geological Survey.

CFR, see Code of Federal Regulations.

Chapman, J.B., R.L. Hershey, and B.F. Lyles. 1995. Groundwater Velocities at the Nevada Test Site: ${ }^{\text {Carbon } 14-}$ Carbon-Based Estimates, Publication No. 45135. Las Vegas, NV: Desert Research Institute, Water Resources Center.

Claassen, H.C. 1973. Water Quality and Physical Characteristics of Nevada Test Site Water Supply Wells, USGS-474-158. Lakewood, CO: U.S. Geological Survey.

Code of Federal Regulations. 1998a. Title 10 CFR Part 20.1402, "Radiological Criteria for Unrestricted Use." Washington, DC: U.S. Government Printing Office.

Code of Federal Regulations. 1998b. Title 40 CFR Part 141.16, "Maximum Contaminant Levels for Beta Particle and Photon Radioactivity from Man-made Radionuclides in Community Water Systems." Washington, DC: U.S. Government Printing Office.

Code of Federal Regulations. 1998c. Title 40 CFR Part 141.80, "Lead and Copper Action Levels." Washington, DC: U.S. Government Printing Office. 
Cole, J.C., R.R. Wahl, and M.R. Hudson. 1989. "Structural Relations Within the Paleozoic Basement of the Mine Mountain Block; Implications for Interpretation of Gravity Data in Yucca Flat, Nevada Test Site." In Proceedings from the Fifth Symposium on Containment of Underground Nuclear Explosions, CONF-8909163, Vol. 2:431-456, 19-21 September. Santa Barbara, CA.

Craig, H. 1961. “Isotopic Variations in Meteoric Waters.” In Science, Vol. 133: 1702-1703.

Daniels, W.R., comp. 1981. Laboratory and Field Studies Related to the Radionuclide Migration Project (October 1, 1979 - September 30, 1980), LA-8670-PR. Los Alamos, NM: Los Alamos National Laboratory.

Daniels, W.R., comp. 1982. Laboratory and Field Studies Related to the Radionuclide Migration Project (October 1, 1980 - September 30, 1981), LA-9192-PR. Los Alamos, NM: Los Alamos National Laboratory.

Daniels, W.R., comp. 1983. Laboratory and Field Studies Related to the Radionuclide Migration Project (October 1, 1981 - September 30, 1982), LA-9691-PR. Los Alamos, NM: Los Alamos National Laboratory.

Daniels, W.R., comp. 1993. Pilot Study Risk Assessment for Selected Problems at the Nevada Test Site (NTS), UCRL-LR-113891. Livermore, CA: Lawrence Livermore National Laboratory.

Daniels, W.R. and J.L. Thompson, comps. and eds. 1984. Laboratory and Field Studies Related to the Radionuclide Migration Project (October 1, 1982 - September 30, 1983), LA-10121-PR. Los Alamos, NM: Los Alamos National Laboratory.

Dash, Z.V., B.A. Robinson, and G.A. Zyvoloski. 1996. V\& V Report for the FEHM Application, Report ECD-22. Los Alamos, NM: Los Alamos National Laboratory.

Davisson, M.L., J.M. Kenneally, D.K. Smith, G.B. Hudson, G.J. Nimz, and J.H. Rego. 1994. Preliminary Report on the Isotope Hydrology Investigations at the Nevada Test Site: Hydrologic Resources Management Program, FY 1992-1993, UCRL-ID-116122. Livermore, CA: Lawrence Livermore National Laboratory.

de Marsily, G. 1986. Quantitative Hydrogeology. Orlando, FL: Academic Press.

Dettinger, M.D., J.R. Harrill, D.L. Schmidt, and J.W. Hess. 1995. Distribution of Carbonate-Rock Aquifers and the Potential for Their Development, Southern Nevada and Adjacent Parts of California, Arizona, and Utah, USGS-WRIR-91-4146. Denver, CO: U.S. Geological Survey.

Deutsch, C.V. and A.G. Journel. 1992. GSLIB, Geostatistical Software Library and User's Guide. New York: Oxford Univ. Press. 
Dixon, G.L., W.J. Carr, A.T. Fernald, and F.M. Byers, Jr. 1965. Geologic Report on Drill Hole Ue11b, Nevada Test Site, USGS-NTS-157, Technical Letter. Denver, CO: U.S. Geological Survey.

Dixon, G.L., W.J. Carr, and W.P. Williams. 1967. Geologic and Geophysical Log of Drill Hole Ue5i, Nevada Test Site, USGS-NTS-186, Technical Letter. Denver, CO: U.S. Geological Survey.

DOE/NV, see U.S. Department of Energy, Nevada Operations Office.

Drellack, Jr., S.L. 1995a. Memorandum TSP-DGP:058:95, Descriptive Narrative for Cross Section MS2, to Edwin H. Price, GeoTrans, Inc., 22 February. Las Vegas, NV: Raytheon Services Nevada.

Drellack, Jr., S.L. 1995b. Selected Stratigraphic Data for Drill Holes Located in Frenchman Flat, Nevada Test Site, TSD:DGP:111:95. Las Vegas, NV: Raytheon Services Nevada.

Drellack, Jr. S.L., L.B. Prothro, K.E. Roberson, B.A. Schier, and E.H. Price. 1997. Analysis of Fractures in Volcanic Cores from Pahute Mesa, Nevada Test Site, DOE/NV/11718-160. Prepared for the U.S. Department of Energy, Nevada Operations Office. Las Vegas, NV: Bechtel Nevada.

Duffield, G.M., H.H. Benegar, and D.S. Ward. 1996. MODFLOWT, A Modular Three-Dimensional Groundwater Flow and Transport Model, User's Manual, Version 1.1. Sterling, VA: HSI GeoTrans, Inc.

Eakin, T.E., G.B. Maxey, and T.W. Robinson. 1951. "Estimated Annual Increment to Groundwater." In Water Resources Bulletin, Contributions to the Hydrology of Eastern Nevada, Bulletin 12: 26-27. Carson City, NV: U.S. Geological Survey.

Ekren, E.B., C.L. Rogers, R.E. Anderson, and P.P. Orkild. 1968. “Age of Basin and Range Normal Faults in Nevada Test Site and Nellis Air Force Range, Nevada, in Nevada Test Site." In Memoir, 110:247-250. Boulder, CO: The Geological Society of America, Inc.

EPA, see U.S. Environmental Protection Agency.

ERDA, see U.S. Energy Research and Development Administration.

Federal Facility Agreement and Consent Order. 1996 (As Amended). Agreed to by the State of Nevada, the U.S. Department of Energy, and the U.S. Department of Defense. Las Vegas, NV.

Feenstra, S., J.A. Cherry, E.A. Sudicky, and Z. Haq. 1984. "Matrix Diffusion Effects on Contaminant Migration from an Injection Well in Fractured Sandstone." In Groundwater, 22 (3): 307-316. Washington, DC: American Geophysical Union. 
Ferguson, J.R., A.H. Cogbill, and R.G. Warren. 1994. "A Geophysical-Geological Transect of the Silent Canyon Caldera Complex, Pahute Mesa, Nevada." In Journal of Geophysical Research, 99 (B3): 4,323-4,339. Washington, DC: American Geophysical Union.

Fernald, A.T., G.L. Dixon, W.J. Carr, and F.M. Byers, Jr. 1965. Geologic Report on Drill Hole Ue11a, Nevada Test Site, USG - NTS-160, Technical Letter. Denver, CO: U.S. Geological Survey.

FFACO, see Federal Facility Agreement and Consent Order.

Fiero, G.W., Jr., J.R. Illian, G.A. Dinwiddie, and L.J. Schroder. 1974. Use of Hydrochemistry for Interpreting Ground-Water Flow Systems in Central Nevada, USGS-474-178. Lakewood, CO: U.S. Geological Survey.

French, R.H. 1983. A Preliminary Analysis of Precipitation in Southern Nevada, DOE/NV/10162-10. Las Vegas, NV: Desert Research Institute.

French, R.H. 1986. Daily, Seasonal, and Annual Precipitation at the Nevada Test Site, Nevada, DOE/NV/10384/01, Publication No. 45042. Las Vegas, NV: Desert Research Institute.

Freeze, R.A., and J.A. Cherry. 1979. Groundwater. Englewood Cliffs, NJ: Prentice Hall.

Gable, C.W., T.W. Cherry, H. Trease, and G.A. Zyvoloski. 1995. Geomesh Grid Generation, Report LA-UR-95-4143. Los Alamos, NM: Los Alamos National Laboratory.

Gelhar, L.W. 1982. Analysis of Two-Well Tracer Tests with a Pulse Input, RHO-BW-CR-131P. Richland, WA: Rockwell Hanford Operations.

Gelhar, L.W., C. Welty, and K.R. Rehfeldt. 1992. "A Critical Review of Data on Field-Scale Dispersions in Aquifers." In Water Resources Research, Vol. 28, (7): 1955-1974. Washington, DC: American Geophysical Union.

Grauch, V.J.S. and M.R. Hudson. 1995. Preliminary Analysis of Major Structures and Lithologic Boundaries for the Frenchman Flat Model Area. Denver, CO: U.S. Geological Survey.

Grindrod, P., and A.J. Lee. 1997. “Colloid Migration in Symmetrical Non-Uniform Fractures: Particle Tracking in Three Dimensions." In Journal of Contaminant Hydrology, 27: 157-175. New York, NY: Elsevier Publishing Co.

Grisak, G.E., J.F. Pickens, and J.A. Cherry. 1980. "Solute Transport Through Fractured Media 2. Column Study of Fractured Till.” In Water Resources Research, Vol. 16, (4): 731-739. Washington, DC: American Geophysical Union.

Gupta, S. 1996. CFEST96, Flow and Solute Transport, Draft User's Manual. Consultant for Environmental System Technologies (CFEST). Irvine, CA. 
Guth, P.L. 1981. "Tertiary Extension North of the Las Vegas Valley Shear Zone, Sheep and Desert Ranges, Clark County, Nevada." In Geological Society of America Bulletin, Part I, 92(10): 763-771. Boulder, CO.

Hadermann, J., and W. Heer. 1996. "The Grimsel (Switzerland) Migration Experiment: Integrating Field Experiments, Laboratory Investigations and Modeling." In Journal of Contaminant Hydrology. 21: 87-100. Amsterdam, The Netherlands: Elsevier Science B.V.

Harrison, B., E.A. Sudicky, and J.A. Cherry. 1992. "Numerical Analysis of Solute Migration Through Fractured Clayey Deposits Into Underlying Aquifers." In Water Resources Research. 28 (2): 515-526. Washington, DC: American Geophysical Union.

Hinrichs, E.N., and E.J. McKay. 1965. "Geologic Map of the Plutonium Valley Quadrangle, Nye and Lincoln Counties, Nevada," GQ-Map 384, Scale 1:24,000. Denver, CO: U.S. Geological Survey.

Hinrichs, E.N. 1968. "Geologic Map of the Camp Desert Rock Quadrangle, Nye County, Nevada," GQ-726, Scale 1:24,000. Denver, CO: U.S. Geological Survey.

Hokett, S.L., and D.R. Gillespie. 1996. Preliminary Evaluation of Recharge Potential at Subsidence Crater U5a in Frenchman Flat, Nevada Test Site, DOE/NV 11508-15, Publication No. 451.47. Las Vegas, NV: Desert Research Institute.

Hoffman, D.C., R. Stone, and W.W. Dudley, Jr. 1977. Radioactivity in the Underground Environment of the Cambric Nuclear Explosion at the Nevada Test Site, LA-6877-MS. Los Alamos, NM: Los Alamos Scientific Laboratory.

Houser, F.N. 1962. "Some Physical Property Data of Samples from U-15a Site, Nevada Test Site, Area 15-2," Technical Letter. Denver, CO: U.S. Department of the Interior Geological Survey.

Howard, N. 1976. Site Characteristic Summary for U5b and U5e Projected from Ue5n, AGTG 76-25. Livermore, CA: Lawrence Livermore National Laboratory.

IT, see IT Corporation.

IT Corporation. 1996a. Groundwater Recharge and Discharge Data Documentation Package (Phase I Data Analysis Documentation, Volume III). Prepared for U.S. Department of Energy, Nevada Operations Office. Las Vegas, NV.

IT Corporation. 1996b. Hydrologic Parameter Data Documentation Package (Phase I Data Analysis Documentation, Volume IV). Prepared for U.S. Department of Energy, Nevada Operations Office. Las Vegas, NV. 
IT Corporation. 1996c. Potentiometric Data Documentation Package (Phase I Data Analysis Documentation, Volume II). Prepared for U.S. Department of Energy, Nevada Operations Office. Las Vegas, NV.

IT Corporation. 1996d. Regional Geologic Model Documentation Package (Phase I Data Analysis Documentation, Volume I). Prepared for U.S. Department of Energy, Nevada Operations Office. Las Vegas, NV.

IT Corporation. 1996e. Transport Parameter and Source Term Data Documentation Package (Phase I Data Analysis Documentation, Volume V). Prepared for U.S. Department of Energy, Nevada Operations Office. Las Vegas, NV.

IT Corporation. 1996f. Tritium Transport Model Documentation Package (Phase I Data Analysis Documentation, Volume VII). Prepared for U.S. Department of Energy, Nevada Operations Office. Las Vegas, NV.

IT Corporation. 1996g. Wells ER-6-1 and ER-6-2 Core Fracture Analyses and Geophysical Log Comparisons. Las Vegas, NV.

IT Corporation. 1997a. Groundwater Flow Model Documentation Package (Phase I Data Analysis Documentation, Volume VI). Prepared for U.S. Department of Energy, Nevada Operations Office. Las Vegas, NV.

IT Corporation. 1997b. Risk Assessment Documentation Package (Phase I Data Analysis Documentation, Volume VIII). Prepared for U.S. Department of Energy, Nevada Operations Office. Las Vegas, NV.

IT Corporation. 1997c. Value of Information Analysis for Corrective Action Unit No. 98: Frenchman Flat. Prepared for the Environmental Restoration Division of the U.S. Department of Energy, Nevada Operations Office. Las Vegas, NV.

IT Corporation. 1998. Corrective Action Unit Modeling Approach for the Underground Test Area, Nevada Test Site, Nye County, Nevada, DOE/NV/13052-501. Las Vegas, NV.

Journel, A.G. 1989. "Fundamentals of Geostatistics in Five Lessons. Short Course in Geology," In American Geophysical Union, Vol. 8. Washington, DC.

Katyal, A.K. 1995. CSMoS Online Model Information for BIOF\&T-3-D, U.S. Environmental Protection - Ada Oklahoma Laboratory. Blacksburg, VA: Draper Aden Environmental Modeling, Inc.

Kingston, W.L., and M. Whitbeck. 1991. Characterization of Colloids Found in Various Groundwater Environments in Central and Southern Nevada, DOE/NV/10384-36, Publication No. 45083. Las Vegas, NV: Desert Research Institute. 
Krishnamoorthy, T.M., R.N. Nair, and T.P. Sarma. 1992. "Migration of Radionuclides from a Granite Repository." In Water Resources Research, 28 (7): 1927-1934. Washington, DC: American Geophysical Union.

Laczniak, R.J., J.C. Cole, D.A. Sawyer, and D.A. Trudeau. 1996. Summary of Hydrogeologic Controls on Ground-Water Flow at the Nevada Test Site, Nye County, Nevada, USGS-WRIR-96-4109. Carson City, NV: U.S. Geological Survey.

Leap, D.I., and P.M. Belmonte. 1992. "Influence of Pore Pressure on Apparent Dispersivity of a Fissured Dolomitic Aquifer." In Groundwater, 30 (1): 87-95. Washington, DC: American Geophysical Union.

Lee, C.H., and I. Farmer. 1993. Fluidflow in Discontinuous Rocks. London, UK: Chapman and Hall.

Lyles, B.F. 1990. Tritium Variations in Groundwater on the Nevada Test Site, DOE/NV/10384-38, Publication No. 45086. Las Vegas, NV: Desert Research Institute.

Lyles, B.F., J. Edkins, R.L. Jacobson, and J.W. Hess. 1990. Time-Series Analysis of Ion and Isotope Geochemistry of Selected Springs of the Nevada Test Site, Nye County, Nevada, Publication No. 45068. Las Vegas and Reno, NV: Desert Research Institute.

Maloszewski, P., and A. Zuber. 1991. "Influence of Matrix Diffusion and Exchange Reactions on Radiocarbon Ages in Fissured Carbonate Aquifers." In Water Resources Research. 27, (8): 1937-1945. Washington, DC: American Geophysical Union.

Marsh, K.V., ed. 1991. Hydrology and Radionuclide Migration Program, 1987 Progress Report, UCRL-53779-87. Livermore, CA: Lawrence Livermore National Laboratory.

Marsh, K.V., ed. 1992. Hydrology and Radionuclide Migration Program, 1988 Progress Report, UCRL-53779-88. Livermore, CA: Lawrence Livermore National Laboratory.

Maxey, G.B. and T.E. Eakin. 1949. Groundwater in White River Valley, White Pine, Nye and Lincoln Counties, Nevada, Water Resources, Bulletin No. 8. Carson City, NV: U.S. Geological Survey.

McKeown, F.A., D.L. Healey, and C.H. Miller. 1976. "Geologic Map of the Yucca Lake Quadrangle, Nye County, Nevada,” Map GQ-1327, Scale 1:24,000. Denver, CO: U.S. Geological Survey.

Meijer, A. 1990. Yucca Mountain Project Far-Field Sorption Studies and Data Needs, LA-11671-MS. Los Alamos, NM: Los Alamos National Laboratory. 
Meyer, G.L., and R.A. Young. 1962. Summary of Hydraulic Data and Abridged Log for Ground-Water Test Well 3, Frenchman Flat, Nevada Test Site, Nevada, USGS NTS-30, Technical Letter. Denver, CO: U.S. Geological Survey.

Miller, C.H., G.L. Dixon, W.J. Carr, and F.M. Byers, Jr. 1967. Geologic and Geophysical Logs of Exploratory Hole Ue-11c, Nevada Test Site, USGS NTS-190, Technical Letter. Denver, CO: U.S. Geological Survey.

Mills, W.B., S. Liu, and F.K. Fong. 1991. "Literature Review and Model (COMET) for Colloid/Metals Transport in Porous Media." In Groundwater, 29 (2): 199-208. Washington, DC: American Geophysical Union.

NAC, see Nevada Administration Code.

National Oceanic and Atmospheric Administration. 1991. Local Climatological Data-Annual. In Summaries for 1990, Part IV-Western Region. Washington, DC: U.S. Department of Commerce.

Neretnieks, I., H. Abelin, and L. Birgersson. 1989. "Some Recent Observations of Channeling in Fractured Rocks - Its Potential Impact on Radionuclide Migration.” In Proceedings of the Conference on Geostatistical, Sensitivity, and Uncertainty Methods for Ground-Water Flow and Radionuclide Transport Modeling, September 15-17, 1987. CONF-8709712: 387-410.

San Francisco, CA: Battelle Press.

Nevada Administrative Code. 1998. NAC 445A, "Water Controls." Carson City, NV: Nevada Division of Environmental Protection.

Nitao, J.J. 1995. Main User's Manual for the NUFT Flow and Transport Code. Livermore, CA: Lawrence Livermore National Laboratory.

NOAA, see National Oceanic and Atmospheric Administration.

Ogard, A.E., J.L. Thompson, R.S. Rundberg, K. Wolfsberg, P.W. Kubik, D. Elmore, and H.W. Bentley. 1988. "Migration of Chlorine-36 and Tritium from an Underground Nuclear Test." In Radiochim. Acta 44/45: 213-217. Munich, Germany, R. Oldenburg.

Pawloski, G.A., Lawrence Livermore National Laboratory. 1998. Personal communication to Robert Sobocinski, IT Corporation, Las Vegas, regarding description of nuclear explosion phenomenology, 20 August. Livermore, CA.

Penrose, W.R., W.L. Polzer, E.H. Essington, D.M. Nelson, and K.A. Orlandini. 1990. “Mobility of Plutonium and Americium Through a Shallow Aquifer in a Semiarid Region." In Environmental Science Technology, 24, (2): 228-234. Columbus, OH: American Chemical Society. 
Pohlmann, K.F. and R. Andricevic. 1994. Identification of Potential Groundwater Flow Paths Using Geological and Geophysical Data, DOE/NV/10845-49, Publication No. 45128. Las Vegas, NV: Desert Research Institute.

Pohlmann, K., C. Shirley, and R. Andricevic. 1996. Near-Field Modeling in Frenchman Flat, Nevada Test Site, Publication No. 45154. Las Vegas, NV: Desert Research Institute.

Pollock, D.W. 1989. Documentation of Computer Programs to Compute and Display Pathlines Using Results from the U.S. Geological Survey Modular Three-Dimensional, Finite-Difference Ground-Water Flow Model, USGS-OFR-89-381. Denver, CO: U.S. Geological Survey.

Ponce, D.A., R.N. Harris, and H.W. Oliver. 1988. Isostatic Gravity Map of the Nevada Test Site and Vicinity, Nevada, USGS-OFR 88-664. Denver, CO: U.S. Geological Survey.

Poole, F.G. 1964. Geology of the Frenchman Flat Quadrangle, Nye, Lincoln, and Clark Counties, Nevada, USGS NTS-73, Technical Letter. Denver, CO: U.S. Geological Survey.

Poole, F.G. 1965. “Geologic Map of the Frenchman Flat Quadrangle, Nye, Lincoln, and Clark Counties, Nevada,” Map GQ-456 Scale 1:24,000. Denver, CO: U.S. Geological Survey.

Poole, F.G., D.P. Elston, and W.J. Carr. 1965. "Geologic Map of the Cane Spring Quadrangle, Nye County, Nevada,” Map GQ-455, Scale 1:24,000. Denver, CO: U.S. Geological Survey.

Prather, T.L. 1965. Preliminary Summary of Lithologic and Hydrologic Data from the UE5f Exploratory Drill Hole, Frenchman Flat, Nevada Test Site, Technical Letter: NTS-133. Denver, CO: U.S. Geological Survey.

Prudic, D.E., J.R. Harrill, and T.J. Burbey. 1993. Conceptual Evaluation of Regional Ground-Water Flow in the Carbonate-Rock Province of the Great Basin, Nevada, Utah, and Adjacent States, USGS-OFR 93-170. Denver, CO: U.S. Geological Survey.

Puls, R.W., R.M. Powell, D.A. Clark, and C.J. Paul. 1991. Facilitated Transport of Inorganic Contaminants in Ground Water: Part II Colloidal Transport, EPA/600/M-01/040. Ada OK: U.S. Environmental Protection Agency, Robert S. Kerr Environmental Research Laboratory.

Quiring, R.F. 1968. Climatological Data Nevada Test Site and Nuclear Rocket Development Station, ERLTM-ARL7, TID-4500 (52 ${ }^{\text {nd }}$ edition). Washington, DC: U.S. Department of Commerce, Environmental Science Services Administration Research.

Ramsay, J.D.F. 1988. "The Role of Colloids in the Release of Radionuclides from Nuclear Waste." In Radiochimica Acta, 44/45: 165-170. Munich, Germany: R. Oldenburg.

Ramspott, L.D., and R.D. McArthur. 1977. Results of the Exploratory Drill Hole Ue5n, Frenchman Flat, Nevada Test Site, UCID-17392. Livermore, CA: Lawrence Livermore National Laboratory. 
REECo, see Reynolds Electrical \& Engineering Company, Inc.

Reeves, M., D.S. Ward, P.A. Davis, and E.J. Bonano. 1986a. SWIFT II Self-Teaching Curriculum, NUREG/CR-3925 and SAND84-1586. Albuquerque, NM: Sandia National Laboratories.

Reeves, M., D.S. Ward, N.D. Johns, and R.M. Cranwell. 1986b. Theory and Implementation for SWIFT II, The Sandia Waste-Isolation Flow and Transport Model for Fractured Media, Release 4.84, NUREG/CR-3328 and SAND83-1159. Albuquerque, NM: Sandia National Laboratories.

Reeves, M., N.A. Baker, and J.O. Duguid. 1994. Review and Selection of Unsaturated Flow Models, Document No. B00000000-01425-2200-00001, Rev. 00. Prepared for the U.S. Department of Energy. Las Vegas, NV: Civilian Radioactive Waste Management System.

Reynolds Electrical \& Engineering Co., Inc. 1994. Site Characterization and Monitoring Data from Area 5 Pilot Wells, Nevada Test Site, Nye County, Nevada, Report DOE/NV-11432-74.

Las Vegas, NV.

Robinson, B.A., A.V. Wolfsberg, G.A. Zyvoloski, and C.W. Gable. 1995. An Unsaturated Zone Flow and Transport Model of Yucca Mountain, Milestone Report 3468. Los Alamos, NM: Los Alamos National Laboratory.

Runchal, A.K., and B. Sagar. 1992. PORFLOW: A Software Tool for Multiphase Fluid Flow, Heat, and Mass Transport in Fractured Porous Media, User's Manual - Version 2.41, CNWRA 92-003. Washington, DC: U.S. Nuclear Regulatory Commission.

Sawyer, D.A., R.J. Fleck, M.A. Lanphere, R.G. Warren, D.A. Broxton, and M.R. Hudson. 1990. "Episodic Volcanism in the Southwest Nevada Volcanic Field: New 40AR/39AR Geochronologic Results." In EOS Transactions, AGU, 71 (43): 1296. Washington, DC: American Geophysical Union.

Schoff, S.L., and J.E. Moore. 1964. Chemistry and Movement of Ground Water, Nevada Test Site, USGS-TEI-838. Denver, CO: U.S. Geological Survey.

Shirley, C., K. Pohlmann, and R. Andricevic. 1996. Three-Dimensional Mapping of Equiprobable Hydrostratigraphic Units at the Frenchman Flat Corrective Action Unit, Nevada Test Site, Publication No. 45152. Las Vegas, NV: Desert Research Institute.

Sinnock, S. 1982. Geology of the Nevada Test Site and Nearby Areas, Southern Nevada, SAND82-2207. Albuquerque, NM: Sandia National Laboratories.

Smith, D.K. 1993. A Review of Literature Pertaining to the Leaching and Sorption of Radionuclides Associated with Nuclear Explosive Melt Glasses, UCRL-ID-113370. Livermore, CA: Lawrence Livermore National Laboratory. 
Smith, D.K. 1995a. Challenges in Defining a Radiologic and Hydrologic Source Term for Underground Nuclear Test Centers, Nevada Test Site, Nye County, Nevada, UCRL-JC-120389. Livermore, CA: Lawrence Livermore National Laboratory.

Smith, D.K. 1995b. Phenomenology of Underground Nuclear Explosions Conducted at the Nevada Test Site with Emphasis on Recent Experience at BASEBALL (U7ba) and INGOT (U2gg). Prepared for the U.S. Department of Energy, Nevada Operations Office. Livermore, CA: Lawrence Livermore National Laboratory.

Smith, D.K., Lawrence Livermore National Laboratory. 1997. Personal communication to Janet Wille, IT Corporation, regarding radionuclides recommended by the UGTA source and transport subcommittee of significance for remedial investigations at the Nevada Test Site. Livermore, CA. April 3.

Smith, D.K., B.K. Esser, J.M. Kenneally, R.J. Nagle, J.H. Rego, and J.L. Royval. 1996. Hydrologic Resources Management Program FY 1995 Progress Report, UCRL-ID-123486. Livermore, CA: Lawrence Livermore National Laboratory.

Smith, D.K., A.B. Kersting, T.P. Rose, J.M. Kenneally, G.B. Hudson, G.F. Eaton, and M.L. Davisson. 1998. Hydrologic Resources Management Program and Underground Test Area Operable Unit FY 1997 Progress Report, UCRL-ID-130792. Livermore, CA: Lawrence Livermore National Laboratory.

Sorenson, K.B., Sandia National Laboratories. 1997. Personal communication to K. Rehfeldt (IT Corporation, Las Vegas, NV.) regarding GANDT User's Manual, 10 July. Albuquerque, NM.

Stewart, J.H. and J.E. Carlson. 1978. “Million-Scale Map of Nevada,” Map 57, Scale 1:500,000. Reno, NV: Nevada Bureau of Mines and Geology.

Sully, M.J., D.E. Cawlfield, D.O. Blout, L.E. Barber, B.L. Dozier, and D.P. Hammermeister. 1993. Characterization of the Spatial Variability of Hydraulic Properties at the Area 5 Radioactive Waste Management Site. Las Vegas, NV: Reynolds Electrical \& Engineering, Inc.

Thomas, J.M. 1996. Geochemical and Isotopic Interpretation of Groundwater Flow, Geochemical Processes, and Age Dating of Groundwater in the Carbonate-Rock Aquifers of the Southern Basin and Range, Ph.D. Dissertation. Reno, NV: University of Nevada.

Thompson, J.L., ed. 1988. Laboratory and Field Studies Related to the Radionuclide Migration Project (October 1, 1986 - September 30, 1987), Progress Report LA-11223-PR. Los Alamos, NM: Los Alamos National Laboratory.

Thompson, J.L., ed. 1991. Laboratory and Field Studies Related to the Hydrology/Radionuclide Migration Project (October 1, 1989 - September 30, 1990), LA-12100-PR, Progress Report. Los Alamos, NM: Los Alamos National Laboratory. 
Thompson, J.L., ed. 1998. Laboratory and Field Studies Related to Radionuclide Migration at the Nevada Test Site (October 1, 1996 - September 30, 1997), LA-13419-PR. Los Alamos, NM: Los Alamos National Laboratory.

Tomasko, D., M. Reeves, V.A. Kelley, and J.F. Pickens. 1989. "Parameter Sensitivity and Importance for Radionuclide Transport in Double-Porosity Systems." In Proceedings of the Conference on Geostatistical Sensitivity, and Uncertainty Methods for Ground-Water Flow and Radionuclide Transport Modeling, September 15-17, 1987, CONF-870971:297-322. B.E. Bufton, ed. Columbus, OH: Battelle Press.

Toran, L., and A.V. Palumbo. 1992. "Colloid Transport Through Fractured and Unfractured Laboratory Sand Columns." In Journal of Contaminant Hydrology, 9: 289-303. Amsterdam, The Netherlands: Elsevier Science Publishers.

Travis, B.J., H.E. Nuttall, S.W. Hodson, and R.S. Rundberg. 1983. "Section B: Transport of Tritium from the Cambric Cavity Region to RNM-2S: Modeling." In Laboratory and Field Studies Related to the Hydrology/Radionuclide Migration Project (October 1, 1981 - September 30, 1982), LA-9691-PR, 9-20, Progress Report. Edited by W.R. Daniels. Los Alamos, NM: Los Alamos National Laboratory.

Travis, B.J. and K.H. Birdsell. 1991. TRACR3D: A Model of Flow and Transport In Porous Media, Model Description and User's Manual, Report LA-11798-M. Los Alamos, NM: Los Alamos National Laboratory.

Trexler, Jr., J.H., J.C. Cole, and P.H. Cashman. 1996. "Middle Devonian-Mississippian Stratigraphy On and Near the Nevada Test Site: Implications for Hydrocarbon Potential." In American Association of Petroleum Geologists Bulletin, 80, (11): 1736-1762. Tulsa, OK.

Triay, I.R., K.H. Birdsell, A.J. Mitchell, and M.A. Ott. 1993. "Diffusion of Sorbing and Non-Sorbing Radionuclides." In Proceedings of the Fourth Annual International High-Level Radioactive Waste Management Conference, Las Vegas, NV, April 26-30, 1993, Vol. 2: 1527-1532. La Grange, IL: American Nuclear Society, Inc., and New York, NY: American Society of Civil Engineers.

Triay, I.R., A. Meijer, J.L. Conca, K.S. Kung, R.S. Rundberg, and E.A. Strietelmeier. 1997. Summary and Synthesis Report on Radionuclide Retardation for the Yucca Mountain Site Characterization Project, Draft, Milestone 3784. Los Alamos, NM: Los Alamos National Laboratory.

Tyler, S.W., W.A. McKay, and T. Mihevc. 1992. "Assessment of Soil Moisture Movement in Nuclear Subsidence Craters." In Journal of Hydrology, 139: 159-181. Amsterdam, The Netherlands: Elsevier Publishing Company.

USC, see United States Code. 
USGS, see U.S. Geological Survey.

United States Code. 1996. 33 USC 1251 et seq., Clean Water Act. Washington, DC: U.S. Government Printing Office.

U.S. Department of Energy, Nevada Operations Office. 1992. Environmental Assessment for the Groundwater Characterization Project, Nevada Test Site, Nye County, Nevada, DOE/EA-0532. Las Vegas, NV.

U.S. Department of Energy, Nevada Operations Office. 1994a. Nevada Environmental Restoration Project Management Plan, Rev. 0. Las Vegas, NV.

U.S. Department of Energy, Nevada Operations Office. 1994b. United States Nuclear Tests, July 1945 through September 1992, DOE/NV--209 (Rev. 14). Las Vegas, NV.

U.S. Department of Energy, Nevada Operations Office. 1995. U.S. Department of Energy Nevada Field Office Annual Site Environmental Report for 1994, DOE/NV/11432-175. Las Vegas, NV.

U.S. Department of Energy, Nevada Operations Office. 1996a. Fluid Management Plan for the Underground Test Area Subproject, DOE/NV--370. Las Vegas, NV.

U.S. Department of Energy, Nevada Operations Office. 1996b. Radiological Effluents Released from U.S. Continental Tests, 1961 through 1992, DOE/NV--317, Rev. 1. Las Vegas, NV.

U.S. Department of Energy, Nevada Operations Office. 1996c. Final Environmental Impact Statement for the Nevada Test Site and Off-Site Locations in the State of Nevada, DOE/EIS 0243. Las Vegas, NV.

U.S. Department of Energy, Nevada Operations Office. 1997. Regional Groundwater Flow and Tritium Transport Modeling and Risk Assessment of the Underground Test Area, Nevada Test Site, Nevada, DOE/NV--477. Prepared by IT Corporation. Las Vegas, NV.

U.S. Department of Energy, Nevada Operations Office. 1998. Underground Test Area Quality Assurance Project Plan. Nevada Operations Office, Revision 2. Prepared by IT Corporation. Las Vegas, NV.

U.S. Energy Research and Development Administration, Nevada Operations Office. 1977. Final Environmental Impact Statement, Nye County, Nevada, ERDA-1551. Las Vegas, NV.

U.S. Environmental Protection Agency. 1993. Data Quality Objectives Process for Superfund, EPA-540-R-93-071. Washington DC.

U.S. Environmental Protection Agency. 1994. Guidance for the Data Quality Objectives Process, EPA QA/G-4. Washington, DC. 
U.S. Geological Survey. 1976. Development of Model for Calculating Disposal in Deep Saline Aquifers, INTERCOMP Resource Development and Engineering, Inc., USGS-WRIR-76-61, Parts I and II. Denver, CO.

U.S. Geological Survey. 1987. U.S. Geological Data Digital Elevation Models: U.S. Geological Survey, National Mapping Program Technical Instructions Data User's Guide, 5. Reston, VA.

van Genuchten, M. Th., and P.J. Wierenga. 1976. "Mass Transfer Studies in Sorbing Porous Media 1, Analytical Solutions." In Soil Science Society of America Journal, 40, (4): 473-480. Madison, WI.

Vilks, P., L.H. Frost, and D.B. Bachinski. 1997. "Field-Scale Colloid Migration Experiments in a Granite Fracture.” In Journal of Contaminant Hydrology, 26: 203-214. New York, NY: Elsevier Publishing Co.

Wahl, R.R, D.A. Sawyer, S.A., Minor, M.D. Carr, J.C. Cole, W.C. Swadley, R.J, Laczniak, R.J.Warren, K.S. Green, and C.M. Engle. 1997. "Digital Geologic Map of the Nevada Test Site Area, Nevada,” USGS-OFR-97-140. Denver, CO: U.S. Geological Survey.

Walter, G.R. 1982. Theoretical and Experimental Determination of Matrix Diffusion and Related Solute Transport Properties of Fractured Tuffs from the Nevada Test Site, LA-9471-MS. Los Alamos, NM: Los Alamos National Laboratory.

Ward, D.S. 1990. Data Input Guide for SWIFT III, The Sandia Waste-Isolation Flow and Transport Model for Fractured Media, Release 2.32, Technical Report. Sterling, CO: HSI GeoTrans.

Ward, D.S., M. Reeves, and L.E. Duda. 1984. Verification and Field Comparison of the Sandia Waste-Isolation Flow and Transport Model (SWIFT), NUREG/CR-3316 and SAND83-1154. Albuquerque, NM: Sandia National Laboratories.

Warren, R.G., D.A. Sawyer, and H.R. Covington. 1989. "Revised Volcanic Stratigraphy of the Southwestern Nevada Volcanic Field." In Proceedings from the Fifth Symposium on Containment of Underground Nuclear Explosives, held on September 19-21, 1989, in Santa Barbara, California, CONF-809163, 2: 387. Livermore, CA: Lawrence Livermore National Laboratory.

Wernicke, B., G.J. Axen, and J.K. Snow. 1988. "Basin and Range Extensional Tectonics at the Latitude of Las Vegas.” In Geological Society of America Bulletin, 100 (11): 1,738-1,757. Boulder, CO.

White, A.F. and N.J. Chuma. 1987. "Carbon and Isotopic Mass Balance Models of Oasis Valley-Fortymile Canyon Groundwater Basin, Southern Nevada." In Water Resources Research, 23 (4): 571-582. Washington, DC: American Geophysical Union. 
White, A.F., H.C. Claassen, and L.V. Benson. 1980. The Effect of Dissolution of Volcanic Glass on the Water Chemistry in a Tuffaceous Aquifer, Rainier Mesa, Nevada, USGS-WSP-1535-Q. Washington, DC: U.S. Geological Survey.

Winograd, I.J. and W. Thordardson. 1975. Hydrogeologic and Hydrochemical Framework, South-Central Great Basin, Nevada-California, with Special Reference to the Nevada Test Site, Professional Paper 712-C. Boulder, CO: U.S. Geological Survey.

Winograd, I.J., and L.R. West. 1962. Preliminary Tracer Experiment to Demonstrate Hydraulic Continuity Between Water Wells C and C-1, Yucca Flat, Nevada Test Site, Technical Letter NTS-20. Denver, CO: U.S. Geological Survey.

Zyvoloski, G.A., B.A. Robinson, Z.V. Dash, and L.L. Trease. 1997a. User's Manual for the FEHM Application-A Finite-Element Heat-and Mass-Transfer Code, LA-13306-M. Los Alamos, NM: Los Alamos National Laboratory.

Zyvoloski, G.A., B.A. Robinson, Z.V. Dash, and L.L. Trease. 1997b. Summary of the Models and Methods for the FEHM Application-A Finite-Element Heat-and Mass-Transfer Code, LA-13307-MS. Los Alamos, NM: Los Alamos National Laboratory. 


\section{Appendix A}

\section{Data Quality Objectives Worksheet}




\section{A.1.0 Data Quality Objectives Worksheet for Frenchman Flat Corrective Action Unit}

\section{STATE THE PROBLEM}

A. Identify the members of the Scoping Team:

\section{Scoping Team}
Department of Energy/
Nevada Division of
Nevada Operations Office
Environmental Protection
R. Bangerter
C. Goewert
IT Corporation/HSI GeoTrans
Bechtel Nevada
J. Wille
P. K. Ortego
W. Fryer
B. Deshler
R. Waddell
K. Rehfeldt
Lawrence Livermore
Los Alamos National Laboratory
National Laboratory
G. Pawloski
W. Hawkins
D. Smith
J. Thompson
W. Hansen
U.S. Geological Survey
Desert Research Institute
R. Laczniak
R. Jacobson
D. Trudeau
C. Russell

\section{Core Decision Team}

R. Bangerter, C. Goewert

\section{Primary Decision Makers}

S. Mellington, P. Liebendorfer

\section{B. Develop/Refine the Conceptual Model.}

1. List sources of historic data associated with previous data collection activities

Historical data sources are included in the regional model documentation (IT, 1996a through f; IT, 1997a and b; and DOE/NV, 1997). 


\section{List ongoing activities}

a. Value of Information Analysis Report for the Frenchman Flat Corrective Action Unit

b. Regional Report and Data Documentation Packages

c. Fiscal Year 1998 Frenchman Flat studies

\section{List known or suspected sources of contamination}

Underground Nuclear Tests:

\begin{tabular}{||c|c|c||}
\hline $\begin{array}{c}\text { Corrective Action Site } \\
\text { Number }\end{array}$ & Test & Emplacement Hole \\
\hline \hline $05-57-001$ & WISHBONE & U-5A \\
\hline $05-57-002$ & DILUTED WATERS & U-5B \\
\hline $05-57-003$ & CAMBRIC & U-5E \\
\hline $05-57-004$ & DERRINGER & U-5I \\
\hline $05-57-005$ & MILK SHAKE & U-5K \\
\hline $11-57-001$ & PIN STRIPE & U-11B \\
\hline $11-57-002$ & NEW POINT & U-11C \\
\hline $11-57-003$ & DIANA MOON & U-11E \\
\hline $11-57-004$ & MINUTE STEAK & U-11F \\
\hline $11-57-005$ & DIAGONAL LINE & U-11G \\
\hline
\end{tabular}

\section{List types of contaminants and affected media}

a. Hydrologic source term: radionuclides such as carbon-14, cesium-137, iodine-129, plutonium-239/240, tritium, uranium-238

b. In Situ Materials: lead, radiochemical detectors, radioactive tracers (yttrium, zirconium, thulium, and lutetium)

c. Radionuclides in order of decreasing risk from contaminated drinking water as determined by the Technical Working Group Source Term Committee: americium-241, plutonium-239/240, curium-244, greater than iodine-129, uranium-234,238, samarium-146, cesium-134,137, greater than sodium-22, europium-152,154, greater than chlorine-36, antimony-125, carbon-14, greater than tin-121, europium 155, technetium-99, calcium-41, promethium-147, greater than nickel-63, samarium-151, greater than tritium

d. Affected medium: groundwater in the vicinity of the shot cavities 


\section{List known or potential routes of migration}

a. Primary Model: horizontal flow in alluvium, pathline of the Regional Flow Model

b. Alternate Model: vertical flux

\section{List known human and environmental receptors}

At the current time, there are no known receptors being affected by existing conditions.

\section{Define the exposure pathway(s)}

For purposes of defining an exposure pathway, a human receptor who installs a drinking water well in the aquifer is postulated.

\section{Define the exposure pathway(s)}

Although there are currently no known receptors, humans are postulated to be exposed to groundwater used as drinking water. Environmental receptors have been considered.

\section{Define the current and future land use}

a. Current: There is a moratorium on underground nuclear testing; with the exception of WW-5a, the groundwater in this area is not being utilized. Surface facilities include the Low-level Radioactive Waste Management Site and the Hazardous Materials Spill Facility.

b. Future: Research, Test and Experimental Zone; HAZMAT Spill Facility; Restricted Access Land Use (Environmental Impact Statement Alternative 3 [DOE/ NV, 1996]). Water resource restrictions are consistent with the boundary.

\section{Define applicable or relevant and appropriate or preliminary remediation goals}

The corrective action strategy for the Underground Test Area is based on the complex corrective action process as outlined in the Federal Facility Agreement and Consent Order. The objective of the corrective action investigation process is to define boundaries around each Underground Test Area CAU that establish areas containing water that may be unsafe for domestic and municipal use (Federal Facility Agreement and Consent Order, Appendix VI, page 3-3 [FFACO, 1996]).

The boundary restrictions are a dose rate limit defined as $4 \mathrm{mrem} / \mathrm{yr}$ with a 50 percent confidence level, representing the median value, over a 1,000-year period using appropriate exposure scenarios.

\section{Develop the exposure scenario}

a. Migration of contaminants into groundwater

b. Flow and Transport Model using dose, time, and confidence level 
c. Contaminant boundary definition in a location to avoid unacceptable exposure

d. Management tool for development of water resources

\section{Specify the available resources}

\section{Specify monetary budget for the investigation}

To be determined based on budgetary constraints

\section{Define relevant time constraints}

Corrective Action Investigation Plan to be completed in the middle of Fiscal Year 1997

(Federal Facility Agreement and Consent Order, Appendix VI, page 3-5 [FFACO, 1996])

\section{E. Description of the problem - combine the relevant background information into a concise description of the problem to be resolved}

Frenchman Flat was the site of ten underground nuclear tests both above and below the water table. The tests have contaminated the groundwater with radionuclides and possibly lead; however, the impact to the groundwater is unknown. The hydrologic flow model for Frenchman Flat is currently under development. Specific, proven, cost-effective technologies that are protective of worker safety and health and that have been demonstrated to either remove radioactive contaminants from the groundwater, stabilize them, or remove the source of the contaminants at the Corrective Action Sites do not currently exist. Such technologies may be perfected in the future, which may alter the choice of corrective action at that time. A contaminant boundary will be developed using a CAU-scale model.

\section{IDENTIFY THE DECISION}

\section{A. Identify the principal study question}

Can a contaminant boundary be defined using a CAU-specific model developed using existing data?

\section{B. Identify alternative action that may be taken based on the findings of the investigation - select the actions that will be taken based on the outcome of the field investigation that corresponds with the selected decision}

Additional field investigations may be necessary if the flow model, based on existing data, cannot provide an acceptable boundary location. 


\section{Identify relationships among decisions}

\section{Prioritize decisions}

a. Adequate data are available to develop the groundwater flow model.

b. After initial model is completed, identify data needs to refine the flow model, if required.

c. Acquire additional data if boundary is unacceptable.

\section{Determine the logical sequence of actions}

To follow the flow chart in Figure 3-4 of the Federal Facility Agreement and Consent Order (FFACO, 1996).

\section{IDENTIFY THE INPUTS TO THE DECISION}

A. Identify the information inputs needed to resolve the decision

1. Model input needed to resolve the decision includes but is not limited to:
a. Scale adequacy
b. Source term
c. Dilution/mixing/dispersion analysis
d. Colloidal transport
e. Geologic detail
f. Uncertainties in parametric values
g. Geochemistry
h. Hydraulic properties

B. Indicate how to generate the necessary data (e.g., sampling modeling, etc.)

\section{Review of existing data}

\section{Inclusion of results from ongoing studies}

\section{Radionuclide transport analysis and simulations using computer modeling. Method to be determined.}

C. Determine the basis for establishing contaminant-specific action level(s) - list the possible basis for establishing the action level (e.g., regulatory threshold, risk or exposure assessment, technological limits, reference based, standards, etc.)

Radionuclides: $4 \mathrm{mrem} / \mathrm{yr}$ with a 50 percent confidence over a 1,000-year period. Chemicals: Action levels will be determined in accordance with the Nevada Division of Environmental Protection Corrective Action regulation and will use Integrated Risk Information System, Risk-Based Corrective Action, and other risk-based data. 


\section{Identify potential sampling approaches and appropriate analytical methods}

Corrective Action Unit modeling will be used to determine the contaminant boundary using existing information. The modeling will consider both radionuclide and chemical contaminants. If additional information is required, the Frenchman Flat Value of Information Analysis (IT, 1997c) contains proposals for data collections.

\section{DEFINE THE BOUNDARIES OF THE STUDY}

A. Define the geographic areas of the field investigation

1. Define the domain or geographic area within which all decisions must apply (in some cases this may be defined by the Corrective Action Unit)

Frenchman Flat CAU

2. Specify the characteristics that define the population of interest

Refer to III.A.1

3. When appropriate, divide the population into strata that have relatively homogeneous characteristics

Hydrostratigraphic units

Types of sources

\section{Define the scale of decision making}

Dependent on the size of the boundary prediction

B. Define the temporal boundaries of the decision to which the study data apply

1,000 years

\section{Identify any practical constraints on data collection}

Budgetary, classification (security issues), regulatory (permitting, Federal Facility Agreement and Consent Order [FFACO, 1996]), and schedule (Federal Facility Agreement and Consent Order deadlines) issues; CAU spending priorities; worker health and safety issues. 


\title{
V. DEVELOP A DECISION RULE - DEFINE A LOGICAL BASIS FOR CHOOSING AMONG ALTERNATIVE ACTIONS
}

\author{
A. Specify the parameter that characterizes the population of interest
}

Dose

B. Specify the action level or preliminary action level for the decision

Radionuclides: $4 \mathrm{mrem} / \mathrm{yr}$ at the 50 percent confidence level

Chemicals: As required in Nevada Administrative Code (NAC, 1998)

C. Develop the decision rule - Combine the outputs of the previous DQO steps into "if ... then ..." decision rules that include the parameters of interest, the action levels, and the alternative actions

If the uncertainty in the $4 \mathrm{mrem} / \mathrm{yr}$ boundary or the chemical of concern action level is unacceptable, then the problem will be reevaluated and negotiated as needed.

\section{SPECIFY ACCEPTABLE LIMITS ON DECISION ERRORS - SPECIFY DECISION ERROR LIMITS BASED ON THE CONSIDERATION OF THE CONSEQUENCES OF MAKING AN INCORRECT DECISION}

A. Determine the upper and lower bounds for the parameter of interest using relevant historical site data

The parameters of interest are the concentrations of the contaminants of concern. The upper bound is the region above the action limit where there is a very high comfort level that sample analysis results would correctly identify the sample as contaminated. The lower bound is the detection limit as specified in the laboratory Statement of Work.

B. Define both types of decision errors and identify the potential consequences of each

If the boundary defined is larger than the actual contaminant transport, then more water resources have been restricted than necessary.

If the boundary defined is smaller than the actual contaminant transport, then less groundwater will be restricted than is necessary to ensure protection of human health and the environment.

VII. OPTIMIZE THE DESIGN - Identify the most resource-effective design for collecting data to decrease the prediction uncertainty, that is expected to satisfy the Data Quality Objectives

Complete ongoing studies and develop the CAU-scale model. 


\section{A.2.0 References}

DOE/NV, see U.S. Department of Energy, Nevada Operations Office.

FFACO, see Federal Facility Agreement and Consent Order.

Federal Facility Agreement and Consent Order. 1996. (As amended). Agreed to by the State of Nevada, the U.S. Department of Energy, and the U.S. Department of Defense.

Las Vegas, NV.

IT, see IT Corporation.

IT Corporation. 1996a. Groundwater Recharge and Discharge Data Documentation Package (Phase 1 Data Analysis Documentation, Volume III). Prepared for the U.S. Department of Energy, Nevada Operations Office. Las Vegas, NV.

IT Corporation. 1996b. Hydrologic Parameter Data Documentation Package (Phase 1 Data Analysis Documentation, Volume IV), Prepared for the U.S. Department of Energy, Nevada Operations Office. Las Vegas, NV.

IT Corporation. 1996c. Potentiometric Data Documentation Package (Phase 1 Data Analysis Documentation, Volume II). Prepared for the U.S. Department of Energy, Nevada Operations Office. Las Vegas, NV.

IT Corporation. 1996d. Regional Geologic Model Data Documentation Package (Phase 1 Data Analysis Documentation, Volume I). Prepared for the U.S. Department of Energy, Nevada Operations Office. Las Vegas, NV.

IT Corporation. 1996e. Transport Parameter and Source Term Data Documentation Package (Phase 1 Data Analysis Documentation, Volume V). Prepared for the U.S. Department of Energy, Nevada Operations Office. Las Vegas, NV.

IT Corporation. 1996f. Tritium Transport Model Documentation Package (Phase 1 Data Analysis Documentation, Volume VII). Prepared for the U.S. Department of Energy, Nevada Operations Office. Las Vegas, NV.

IT Corporation. 1997a. Groundwater Flow Model Documentation Package (Phase 1 Data Analysis Documentation, Volume VI). Prepared for the U.S. Department of Energy, Nevada Operations Office. Las Vegas, NV. 
IT Corporation. 1997b. Risk Assessment Documentation Package (Phase 1 Data Analysis Documentation, Volume VIII). Prepared for the U.S. Department of Energy, Nevada Operations Office. Las Vegas, NV.

IT Corporation. 1997c. Value of Information Analysis for Corrective Action Unit No. 98:

Frenchman Flat. Prepared for the Environmental Restoration Division of the U.S. Department of Energy, Nevada Operations Office. Las Vegas, NV.

NAC, see Nevada Administrative Code.

Nevada Administrative Code. 1998. NAC 445A, "Water Controls." Carson City, NV: Nevada Division of Environmental Protection.

U.S. Department of Energy, Nevada Operations Office. 1996. Final Environmental Impact Statement for the Nevada Test Site and Off-Site Locations in the State of Nevada, DOE/EIS 0243. Las Vegas, NV.

U.S. Department of Energy, Nevada Operations Office. 1997. Regional Groundwater Flow and Tritium Transport Modeling and Risk Assessment of the Underground Test Area, Nevada Test Site, Nevada, DOE/NV--477. Prepared by IT Corporation. Las Vegas, NV. 


\section{Distribution}

Paul J. Liebendorfer

State of Nevada

Bureau of Federal Facilities

Division of Environmental Protection

333 W. Nye Lane, Room 138

Carson City, NV 89706-0851

Supervisor

State of Nevada

Bureau of Federal Facilities

Division of Environmental Protection

555 E. Washington, Suite 4300

Las Vegas, NV 89101

Sabrina Lawrence

Environmental Restoration Division

DOE/Nevada Operations Office

P.O. Box 98518, M/S 505

Las Vegas, NV 89193-8518

Robert M. Bangerter, Jr.

Environmental Restoration Division

DOE/Nevada Operations Office

P.O. Box 98518, M/S 505

Las Vegas, NV 89193-8518

DOE/Nevada Operations Office

Technical Information Resource Center

P.O. Box 98518

Las Vegas, NV 89193-8518

U.S. Department of Energy

Office of Scientific and Technical Information

175 Oak Ridge Turnpike

Post Office Box 62

Oak Ridge, Tennessee 37831

Southern Nevada Public Reading Room

c/o Rosa Silver

P.O. Box 98521, M/S NLV 040

Las Vegas, NV 89193-8521
2 (Controlled)

1 (Controlled)

1 (Controlled)

1 (Controlled)

1 (Uncontrolled)

2 (Uncontrolled)

1 (Controlled)

1 (Uncontrolled) 
Northern Nevada Public Reading Room

1 (Uncontrolled)

c/o Rosa Silver

100 N. Stewart St.

Carson City, NV 89701-4285

Paul K. Ortego

1 (Uncontrolled)

Bechtel Nevada

2621 Losee Road

M/S NLV082

Las Vegas, NV 89030

Ward Hawkins

1 (Uncontrolled)

Los Alamos National Laboratory

SM-30 Bikini Atoll Road

Los Alamos, NM 87545

Dave Smith

1 (Uncontrolled)

Lawrence Livermore National Laboratory

7000 East Avenue

Livermore, CA 94550

Gayle Pawloski

1 (Uncontrolled)

Lawrence Livermore National Laboratory

P.O. Box 808, M/SL-231

Livermore, CA 94551

Chuck Russell

1 (Uncontrolled)

Desert Research Institute

755 E. Flamingo

Las Vegas, NV 89119

Doug Trudeau

1 (Uncontrolled)

U.S. Geological Survey

6770 Paradise Rd.

Las Vegas, NV 89119

Janet Wille

1 (Uncontrolled

IT Corporation

2621 Losee Road, B-1

N. Las Vegas, NV 89030 
IT Corporation

1 (Uncontrolled)

Central Files

P.O. Box 93838

Las Vegas, NV 89193-3838 